\title{
EFEITOS DAS ADMINISTRAÇÕES DE $\beta$-CAROTENO E VITAMINA A EM RATOS WISTAR NA ETAPA DE PROGRESSÃO DO MODELO DE HEPATOCARCINOGÊNESE DO "HEPATÓCITO RESISTENTE"
}

FERNANDO SALVADOR MORENO

Tese apresentada à Comissão Julgadora do Concurso para Livre-Docência junto à Área de Nutrição Humana do Departamento de Alimentos e Nutrição Experimental da Faculdade de Ciências Farmacêuticas da Universidade de São Paulo 
EFEITOS DAS ADMINISTRACCÕES DE B-CAROTENO E VITAMINA A EM RATOS WISTAR NA ETAPA DE PROGRESSÃO DO MODELO DE HEPATOCARCINOGÊNESE DO "HEPATOCITO RESISTENTE"

\section{FERNANDO SALVADOR MORENO}

Tese apresentada à Comissão julgadora do Concurso para Livre-Docência junto à Área de Nutrição Humana do Departamento de Alimentos $e$ Nutrição Experimental da Faculdade de Ciências Farmacêuticas da Universidade de São Pauio 


\section{YOSO UNIVERSIDADE DE SÃO PAUTO Faculdade de Ciências Farmacêuticas}

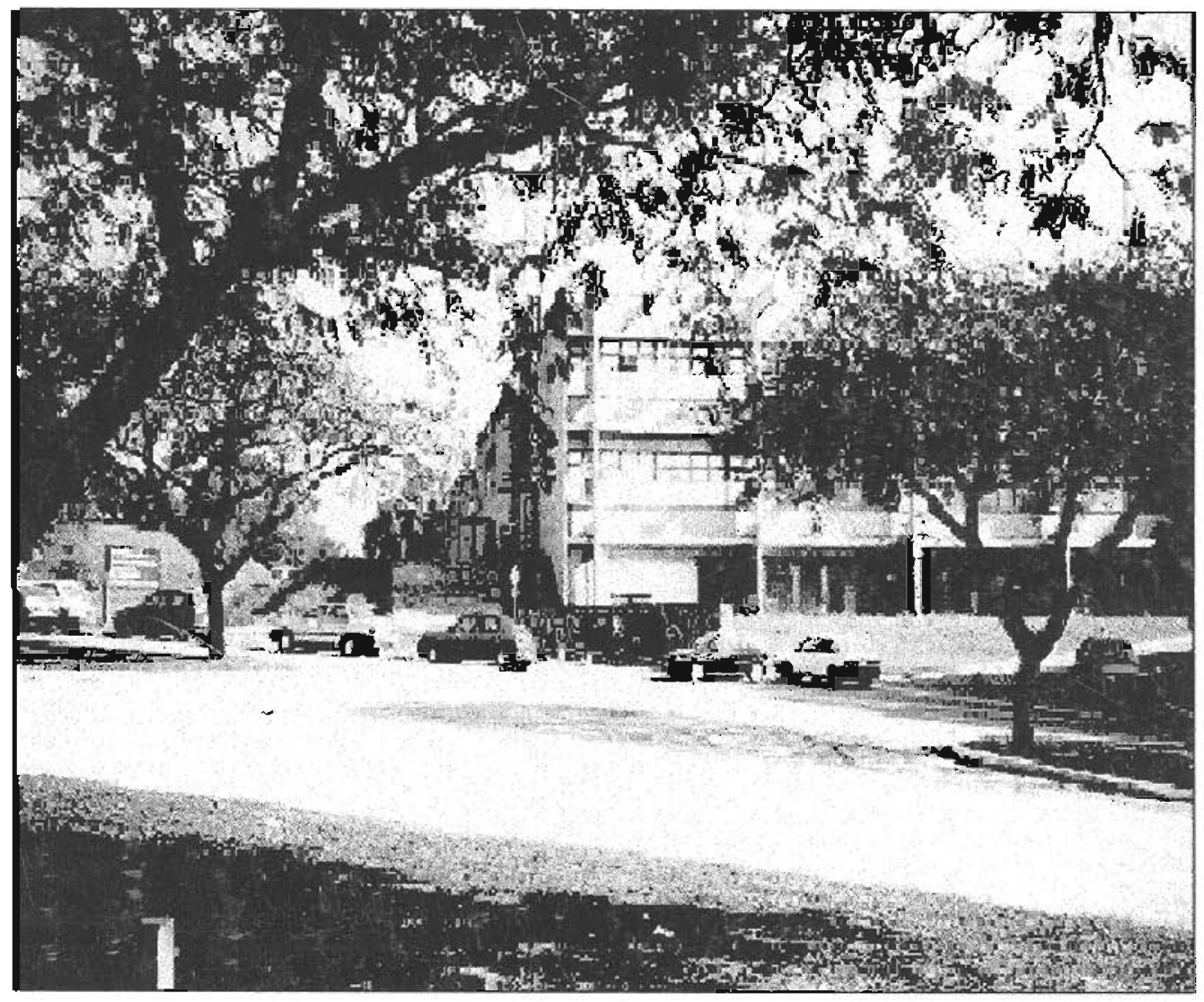




\section{Um Chamado João}

João era fabulista?

fabuloso?

fábula?

Sertão místico disparando

no exílio da linguagem comum?

Projetava na gravatinha

a quinta face das coisas, inenarrável narrada?

Um estranho chamado João

para disfarçar, para farçar

o que não ousamos compreender?

Tinha pastos, buritis plantados

no apartamento?

no peito?

Vegetal ele era ou passarinho

sob a robusta ossatura com pinta

de boi risonho?

Era um teatro

e todos os artistas

no mesmo papel,

ciranda multívoca?

João era tudo?

tudo escondido, florindo

como flor é flor, mesmo não semeada?

Mapa com acidentes

deslizando para fora, falando?

Guardava rios no bolso

cada qual com a cor de suas águas?

Sem misturar, sem conflitar?

$E$ de cada gota redigia nome, curva, fim, e no destino geral

seu fado era saber

para contar sem desnudar

o que não deve ser desnudado

e por isso se veste de véus novos?

Mágico sem apetrechos,

civilmente mágico, apelador de precipites prodigios acudindo a chamado geral? 
Embaixador do reino

que há por trás dos reinos, dos poderes, das

supostas fórmulas

de abracadabra, sésamo?

Reino cerrado

não de muros, chaves, códigos,

mas o reino-reino?

Por que João sorria

se lhe perguntavam

que mistério é esse?

E propondo desenho figurava

menos a resposta que

outra questão ao perguntante?

Tinha parte com... (não sei

o nome) ou de mesmo era

a parte da gente

servindo de ponte

entre o sub e o sobre

que se arcabuzeiam

de antes do princípio,

que se entrelaçam

para melhor guerra,

para maior festa?

Ficamos sem saber o que era João

e se João existiu de se pegar. 


\section{Dedico esta Tese e agradeço}

a Leus pela oportunidade concedida de poder observar mais de perto este espetáculo que é a natureza em diversas de Suas manifestações;

Com Deus existindo, tudo dá esperança:

sempre um milagre é possivel, o mundo se resolve.

Mas se nāo tem Deus, há de a gente perdidos no

vai-vem, e a vida é burra... Tendo Deus, é menos

grave se descuidar um pouquinho, pois, no fim

dá certo. Mas, se não tem Deus, entāo, a gente

não tem licença de coisa nenhuma!

(João Guimarães Rosa)

a Lilo e José também pela oportunidade de me abrirem os caminhos sem questionar, sempre dando o apoio necessário para que neles trilhasse;

à Ró pelo amor sempre presente em todas as instâncias;

Du hast die schönsten Augen

Mädchen, was willst du mehr?...

(Dostoiévski)

a Manu e Fu pelos ensinamentos e compreensão em relação a momentos em que infelizmente nāo estive presente;

- As idéias não são de ninguém - disse.

Com o indicador desenhou no ar uma série

de circulos contínuos, e concluiu: - Andam

voando por ai, como os anjos.

(Gabriel Garcia Márquez)

A aspiração à verdade não é outra coisa

senão a expansão da alma e do conteúdo

que por natureza ela contém.

(Ménon - Platão apuơ Werner Jaeger. In: Paideia, pg. 663)

ao Professor Hélio, querido e respeitado amigo, a quem muito devo em diversos momentos cruciais de minha vida profissional. 


\section{Meus Agradecimentos ainda}

a Elaine Regina, Margareth, Ton, Silvia Catarina, Cida, Cláudia, Bia, Suzana e Wagner, que participaram diretamente e sempre com alegria da parte experimental desta Tese, e sem a colaboração dos quais esta não teria sido possivel;

à Silvânia pela cooperação sempre solicita e gentil em todos os trabalhos que tive oportunidade de utilizar animais da FCF-USP, inclusive nesta Tese;

à minha querida cunhada Maria pelo auxilio para com a digitalização e preparo das Figuras;

às Professoras Malu e Marilene pela colaboraçāo direta para com a linha de pesquisa "Dieta, Nutrição e Câncer" em diversos de seus aspectos, e pelo apoio e amizade durante todos esses anos;

ao Professor Guerra que também sempre estimulou nossas pesquisas, tratando-me como amigo e "abrindo as portas" do Departamento de Patologia da FMVZ-USP;

à Professora Silvia, "grande ser humano" e docente da área de Nutrição, e a quem devo inclusive o estímulo para que procurasse me tornar um Professor efetivo junto à USP;

aos Professores Célia e Júlio pela amizade e pelo fato de sempre termos trabalhado em conjunto pela Nutrição, em um ambiente harmônico, alegre e construtivo;

aos Professores Beatriz, Franco, João, Jorge e Maria Tereza por me terem facilitado as dependências e equipamentos de seus laboratórios, bem como pela atitude amiga e pelas conversas agradáveis e enriquecedoras, tenham sido elas de cunho científico, político ou não;

ao amigo Professor Dirceu, pela orientação em relação às medidas adequadas de proteção a serem tomadas por ocasiāo da realização de trabalhos que envolvam a utilização de radioisótopos;

a meus orientados, Bia, Ton, Alda, Valzimeire, Elaine Regina, Margareth, Luciana, Roseli, Fabiana, Elaine e Cida, pelo convivio estimulante, ensinamentos e colaboração para com a linha de pesquisa "Dieta, Nutrição e Câncer", bem como para comigo;

às secretárias Angela, Bel e Mônica, pela competência, dedicação e gentileza com que sempre me auxiliaram nesses vários anos;

aos técnicos de laboratório Sandra, Teresa Cristina e Renato, bem como a Joana e Lurdes, auxiliares de serviços gerais do Departamento, pelo apoio e auxílio com alegria;

a Joāo e à Equipe de Manutenção da FCF-USP, pela solicitude e presteza sempre presentes no atendimento;

à CAPES, CNPq e FAPESP, pelas bolsas e auxilios sem os quais não teria sido possivel que se implementasse a linha de pesquisa "Dieta, Nutrição e Câncer";

aos alunos de graduação e de pós-graduação de uma forma geral, por significarem o motivo maior de minha dedicação junto à Universidade. 


\section{SUMÁRIO}

Pág.

1. INTRODUÇĀO.

2. REVISÃO DA LITERATURA.

2.1 Câncor

2.2 Carcinogènese

2.2.1 Proliferą̧ão, Apoptose e Diferenciaçăo Cełular .............................................................. 06

2.2.2 Agentes capazes de Induzir a Carcinogênese ................................................................ 07

2.2.2.1 Carcinogênese Quimica ....................................................................................... 08

2.2.3 Metilą̧ăo do DNA ............................................................................................... 10

2.2.4 Proto-oncogenes $\theta$ Anti-oncogenes ............................................................................. 12

2.3 Hepatocarcinogênese ............................................................................................ 14

2.3.1 Modelos Experimentais de Hepalocarcinogênese Quimica ........................................... 16

2.3.2 O Modelo de Hepatocarcinogênese do "Hepatócito Resistente" ...................................... 18

2.3.3 Origem Celular do Hepalocarcinoma .......................................................................... 20

2.4 A Relação Alimenlaçăo—Nutrição—Câncer e sua Importância ............................................. 21

2.5 Quimioprevenção do Câncer e Anticarcinogênicos dos Alimentos ....................................... 23

2.6 Carotenóides e $\beta$-Caroteno .......................................................................................... 25

2.6.1 Absorçäo, Transporte, Metabolismo e Armazenamento do $\beta$-Caroteno ............................. 27

2.6.2 Propriedades Biológicas do $\beta$-Caroteno ....................................................................... 31

2.6.3 $\beta$-Caroteno e Câncer ......................................................................................... 32

2.6.3.1 Estudos em Humanos ........................................................................................... 32

2.6.3.2 Estudos in vito e em Animais de Experimentação ........................................................... 34

2.6.3.2.1 $\beta$-Caroteno \& Hepatocarcinogênese Experimental ..................................................... 36

2.6.3.3 Mecanismos de Ação do ß-caroleno Envolvidos com a Carcinogênese .......................... 38

2.7 Retinóides .............................................................................................................. $\quad 40$

2.7.1 Absorção, Transporte, Melabolismo \& Armazenamento de Retinóides Naturais ............... $\quad 41$

2.7.2 Propriedades Biológicas dos Retinóides Naturais ..........................................................

2.7.3 Retinóides $\theta$ Câncer ................................................................................................. 47

2.7.3.1 Estudos em Humaros .............................................................................................. 47

2.7.3.2 Estudos in vito e em Animais de Experimentaçāo ......................................................... $\quad 50$

2.7.3.2.1 Retinóides e Hepatocarcinogênese Experimental ...................................................... 52

2.7.3.3 Mecanismos de Ação dos Retinóides Envolvidos com a Carcinogênese ......................... 53

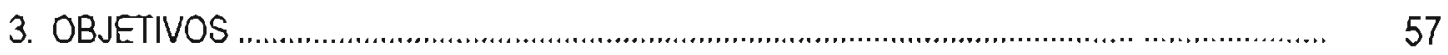

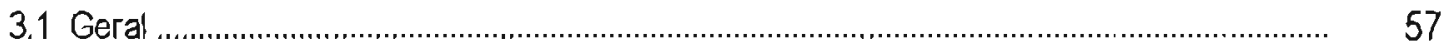

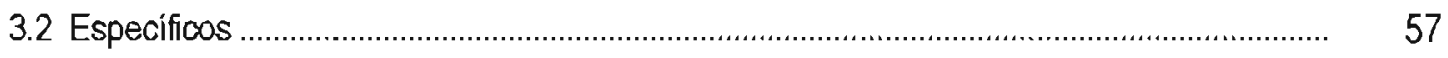

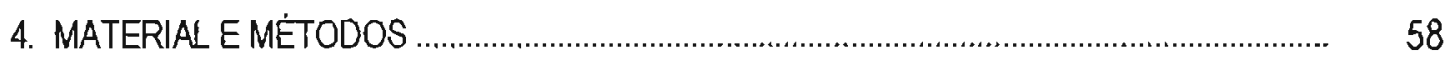

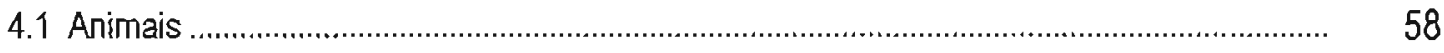

4.2 Delineamento experimental .............................................................................................. 58

4.3 Verificação da Pureza do $\beta$-caroteno e da Vitamina A a Serem Administrados nos

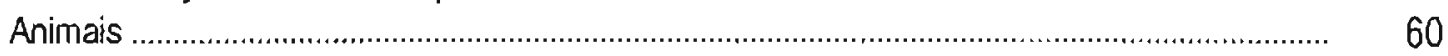

4.4 Sacrificio dos Animais ................................................................................................. 60

4.5 Exame Macroscópico ….......................................................................................... 61

4.6 Exame Micros $\infty$ pio …...................................................................................... 64 
4.6.1 Microscopia de Luz ........................................................................................... 64

4.6.1.1 Histoquimica Enzimätica para Evidenciação da Afividade de $\gamma$-glutamiltranspeptidase $(\gamma G) . \quad 64$ 4.6.1.2 Exame Histopatológico Através de Coloração pela Hematoxilina e Eosina ................... 65

4.6.1.3 Exame Imunohistoquimico para a BrDU .................................................................... 65

4.6.1.3.1 Quantiricação dos Hepatócitos Marcados com BrDU ............................................... 66

4.7 Determinaçāo das Concentraçõos Hepáticas de $\beta$-caroteno e retinol .................................. 68

4.8 Determinaçāo da Concentração Hepática de DNA ............................................................. 69

4.9 Análise do Padrão de Metilação dos proto-oncogenes c-Ha-ras e c-myc, bem como do Gene que Codifica para a Enzima HMGCoA Redutase .......................................................... $\quad 70$

4.9 .1 Isolamento do DNA Genômico ................................................................................. $\quad 70$

4.9.2 Digestão do DNA Genômico com Enzimas de Restrição .................................................. 71

4.9.3 Eletroforese em Gel de Agarose e Transferência para Suporte Solido ............................. $\quad 71$

4.9.4 Pré-hibridizaçāo, Hibridização, Lavagem da Membrana $\theta$ Autorradiografia ....................... $\quad 71$

4.9.5 Origem das Sondas e suas Marcaçōes …………………............................................. $\quad 72$

4.10 Análise Estaústica ................................................................................................ 73

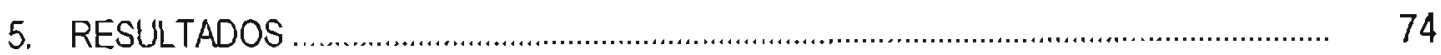

5.1 Curva Ponderal dos Animais Durante Aplicação do Modelo de Hepalocarcinogênese ........ 74

5.2 Pesos Corpóreos ao Inicio e Final do Tratamento, Bem como Pesos dos Figados por Ocasião do Sacrificio

5.3 Quantificação das Lesöes Nodulares e de Cânceres Observados Macroscopicamente ............... 77

5.4 Quantificação dos Focos e Nóduios de Hepatócitos Marcados Positivamente pela

Enzima $\gamma$-glutamiltranspeptidase $(\gamma G T)$

5.5 Exame Histopatológico dos Figados dos Ratos Atraves de Color ação pela Hematoxilina

e Eosina.

5.5.1 Observaçāo Geral ..................................................................................................... 79

5.5.2 Observação Especíica ................................................................................................ 80

5.6 Avaliaçäo das Concentraçöes Hepálicas de $\beta$-caroteno e Retinol ..................................... $\quad 82$

5.7 Avalią̧ão da Prolíferação Celular Hepática ....................................................................... 83

5.8 Padrão de Metilação dos prolo-oncogenes c-Ha-ras, c-myc, bem como do Gene que Codifica para a Enzima HMGCOA Redutase

6.1 Sobre a Quantificação à Macroscopia das Lesōes Pré-neoplásicas e Neoplásicas Presentes nos Fígados de Ratos Wislar Submelidos ao Modelo do "Hepatócito Resistente" $e$ Trałados com Óleo de Mílho, $\beta$-Caroteno ou Vitamina A Durante a Fase de Progressão da Hepatocarcinogênese.

6.2 Sobre a Quantificação à Microscopia das Lesões Pré-Neoplásicas e Neoplásicas Positivas para a yGt Presentes nos Figados De Ratos Wistar Submetidos ao Modelo do "Hepalócito Resistenten e Tratados com Óleo de Milho, $\beta$-Caroteno ou Vitamina a Durante a Fase de Progressão da Hepatocarcinogênese.

6.3 Sobre os Aspectos Morfológicos e a Quantificaçāo das Lesōes Hepàticas por Ocasião da Realização Do Exame Histopatológico dos Figados de Ratos Wistar Submelidos ao Modelo do "Hepatócito Resistente" $\Theta$ Tratados com Óleo de Milho, $\beta$-caroleno ou Vitamina A Durante a Fase de Progressão da Hepalocarcinogênese. 
Pág.

6.5 Sobre a Proliferação Celular no Figado e Lesões Neoplásicas Hepáticas de Ralos Wistar Submetióos ao Modelo do "hepatócito resistente" e Tratados com Óleo de Milho, $\beta$-caroleno ou Vitamina A Durante a Fase de Progressāo da Hepatocarcinogênese.

6.6 Sobre o Padrāo de Metilação dos Proto-oncogenes c-Ha-ras e c-myc, bem como do Gene que Codifica para a Enzima HMGCoA Redukase, do Figado $\theta$ de Lesōes Hepáticas (nódulos persistentes/cânceres) de Ratos Wistar Submelidos ao Modelo do "hepalócito resistente $\theta$ Tratados com Óleo de Milho, $\beta$-caroteno ou Vitamina A Durante a Fase de Progressão da Hepatocarcinogênese.

7. CONCLUSÕES

8. REFERENCIAS BIBLIOGRÁFICAS 


\section{LISTA DE FIGURAS}

Pág.

FIGURA 1. Representação esquemática do modelo experimental

FIGURA 2. Aspecto macroscópico de figado de rato tatado com óleo de mitho (a), $\beta$ caroteno (b) ou vitamina $A$ (c) por oito semanas consecutivas durante a fase de progressão do modelo de hepatocarcinogénese do "hepatócito resistente". Observar a presença de formaçôes nodulares (seta) na superficie, de cor amarelada e com contornos bem definidos

Figura 3 a e b. Aspecto macroscópico de figado de rato tratado com óleo de milho por oito semanas consecutivas durante a fase de progressão do modelo de hepatocarcinogênese do "hepatócito resistente". Observar na superficie dos diversos lobos hepáticos, a presença de formações nodulares de coloraçāo amarelada ou esbranquiçada, com volumes desiguais e contornos irregulares e mal delimitados, comprometendo e deformando grosseiramente o órgâo

Figura 4. Núcleos de hepatócitos corados em marrom (seta) apresentando padrão tipico de marcação de BrDU. (Esteptavidina-biotina-peroxidase/Hematoxilina, 560x) ..

Figura 5. Curva de peso dos ratos Wistar durante a aplicação do modelo do "hepatócito resistente"

Figura 6. Digitalizaçāo de autorradiografia demonstrando padrões de fragmentos de restrição, dos DNAs extraidos de amostras de figado de ratos normais (colunas a e b), do tecido hepatico ao redor de lesões (colunas c, $d$ e e) e das próprias lesões hepáticas (nódulos persistentes/cânceres) de animais tratados com óleo de milho (colunas $f$ [nódulo persistente], $g$ e $h$ [cânceres]), $\beta$-caroteno (colunas i [nódulo persistente], ] e I [cânceres]) ou vitamina A (colunas m [nódulo persistente], n e o [cânceres]) durante a fase de progressão do modelo de hepatocarcinogênese do "hepatbcito resistente", digeridos com a enzima Hpa Il e hibridizados com sonda para o proto-oncogene c-Ha-ras

Figura 7. Digitalização de autorradiografia demonstrando padrōes de fragmentos de restrição, dos DNAs extraiclos de amostras de figado de ratos normais (colunas a e b), do tecido hepático ao redor de lesões (colunas $\mathbf{c}, \mathbf{d}$ e e) e das próprias lesões hepáticas (nódulos persistentes/cânceres) de animais tratados com óleo de milho (colunas $f$ [nódulo persistente], $g$ e $\mathrm{h}$ [cânceres]), $\beta$-caroteno (colunas i [nódulo persistente], j e I [cânceres]) ou vitamina $A$ (colunas $m$ [nódulo persistente], n e o [cânceres]) durante a fase de progressão do modelo de hepatocarcinogênese do "hepatócito resistente", digeridos com a enzima Msp I e hibridizados com sonda para o proto-oncogene c-Ha-ras 
Figura 8. Digitalização de autorradiografia demonstrando padrōes de fragmentos de restrição, do DNA extraido de amostra de tecido ao redor de lesōes hepáticas de rato tratado com vitamina A durante a fase de progressão do modelo de hepatocarcinogénese do "hepatócito resistente", digerido por periodos que variaram de 1 a 6 horas com a enzima Hpa II ou Msp I e hibridizado com sonda para o protooncogene c-Ha-ras

Figura 9. Digitalização de autorradiografia apresentando padrões de fragmentos de restrição, do DNA extraido de nódulo persistente de hepatócitos de rato tratado com ß-caroteno durante a fase de progressão do modelo de hepatocarcinogênese do "hepatócito resistente", digerido por períodos que variaram de 1 a 6 horas com a enzima Hpa Il ou Msp l e hibridizado com sonda para o proto-oncogene c-Ha-ras ........

Figura 10. Digitalização de autorradiografia demonstrando padrōes de fragmentos de restrição, dos DNAs extraidos de amostras de figado de ratos normais (colunas a e b), do tecido hepático ao redor de lesões (colunas c, d e e) e das próprias lesões hepáticas (nódulos persistentes/cànceres) de animais tratados com óleo de milho (colunas $f$ [nódulo persistentel, $g$ e $\mathbf{h}$ [cânceres]), $\beta$-caroteno (colunas i [nódulo persistente], j e 1 [cânceres]) ou vitamina $A$ (colunas $m$ [nódulo persistente], $n$ e 0 [cânceres]) durante a fase de progressão do modelo de hepatocarcinogênese do "hepatócito resistente", digeridos com a enzima Hpa II e hibridizados com sonda para o proto-oncogene c-myc

Figura 11. Digitalização de autorradiografia demonstrando padrões de fragmentos de restrição, dos DNAs extraidos de amostras de figado de ratos normais (colunas a e b), do tecido hepático ao redor de lesões (colunas $c, d$ e e) e das próprias lesōes hepáticas (nódulos persistentes/cànceres) de animais tratados com óleo de milho (colunas f [nódulo persistente], g e $\mathrm{h}$ [cânceres]), $\beta$-caroteno (colunas i [nódulo persistente], j e I [cânceres]) ou vitamina A (colunas $m$ [nódulo persistente], n e o [cânceres]) durante a fase de progressão do modelo de hepatocarcinogènese do "hepatócito resistente", digeridos com a enzima Msp I e hibridizados com sonda para o proto-oncogene c-myc

Figura 12. Digitalização de autorradiografia demonstrando padrōes de fragmentos de restrição, dos DNAs extraidos de amostras de figado de ratos normais (colunas a e b), do tecido hepático ao redor de lesões (colunas $\mathbf{c}$, $\mathbf{d}$ e e) e das próprias lesōes hepáticas (nódulos persistentesicânceres) de animais tratados com óleo de milho (colunas f [nódulo persistente], g e $\mathrm{h}$ [cánceres]), $\beta$-caroteno (colunas i [nódulo persistente], j e I [cânceres]) ou vitamina $A$ (colunas $m$ [nódulo persistente], n e o [cânceres]) durante a fase de progressão do modelo de hepatocarcinogénese do "hepatócito resistente", digeridos com a enzima Hpa ll e hibridizados com sonda para o gene que codifica para a enzima HMGCoA redutase 
Pág.

Higura 13. Digitalização de autorradiografía demonstrando padrões de fragmentos de restriçāo, dos DNAs extraídos de amostras de figado de ratos normais (colunas a e b), do tecido hepático ao redor de lesões (colunas c, d e e) e das próprias lesões hepáticas (nódulos persistentes/cânceres) de animais tratados com óleo de milho (colunas $f$ [nódulo persistente], $g$ e h [cânceres]), $\beta$-caroteno (colunas i [nódulo persistente], ] e I [cânceres]) ou vitamina $A$ (colunas $m$ [nódulo persistente], $n$ e 0 [cánceres]) durante a tase de progressão do modelo de hepatocarcinogênese do "hepatócito resistente", digeridos com a enzima Msp I e hibridizados com sonda para o gene que codifica para a enzima HMGCoA redutase 


\section{LISTA DE TABELAS}

Pág.

Tabela 1. Pesos corpóreos e dos figados de ratos Wistar submetidos ao modelo do "hepatócito resistente" e tatados com oleo de milho (grupo OM - controles), $\beta$ caroteno (grupo BC) ou vitamina A (grupo VA), por 8 semanas consecutivas, durante a fase de progressão da hepatocarcinogênese.

Tabela 2. Quantificação das lesões nodulares macroscópicas, bem como de cânceres, de ratos Wistar submetidos ao modelo do "hepatocito resistente" e tratados com óleo de milho (grupo OM - controles), $\beta$-caroteno (grupo $\beta C$ ) ou vitamina $A$ (grupo VA) por 8 semanas consecutivas, durante a fase de progressão da hepatocarcinogênese.

Tabela 3. Quantificação dos focos e nódulos pré-neoplásicos (F/N) positivos para a enzima $\gamma \mathrm{GT}$, de ratos Wistar submetidos ao modelo do "hepatócito resistente" e tratados com óleo de milho (grupo OM - controles), $\beta$-caroteno (grupo $\beta C$ ) ou vitamina A (grupo VA) por 8 semanas consecutivas, durante a fase de progressão da hepatocarcinogênese

Tabela 4. Concentraçōes hepáticas de $\beta$-caroteno e retinol, de ratos Wistar subrnetidos ao modelo do "hepatbcito resistente" e tratados com óleo de milho (grupo OM - controles), $\beta$-caroteno (grupo $\beta C$ ) ou vitamina A (grupo VA) por 8 semanas consecutivas, durante a fase de progressão da hepatocarcinogênese.

Tabela 5. Concentrações hepáticas de DNA de animais submetidos ao modelo do "hepatócito resistente" e tratados com óleo de milho (grupo OM - controles), $\beta$ caroteno (grupo $\beta C$ ) ou vitamina $A$ (grupo VA) por 8 semanas consecutivas, durante a fase de progressão da hepatocarcinogênese.

Tabela 6. Índice de Marcação com a BrDU, de Amostras de Fígado de Ratos Normais (Nenhum Tratamento), Bem Como De Áreas “Normais" Ao Redor Das Lesões, E Das Próprias Lesōes, De Animais Submetidos Ao Modelo Do "Hepatócito Resistente" E Tratados Com Oleo De Milho, $\beta$-Caroteno Ou Vitamina A Por 8 Semanas Consecutivas, Durante A Fase De Progressāo Da Hepatocarcinogênese. 


\section{LISTA DE QUADRO}

Pág.

Quadro 1. Incidência e descrição das lesōes neoplásicas benignas e malignas, bem como de outras lesóes hepáticas, de ratos Wistar submetidos ao modelo do "hepatócito resistente" e tratados com óleo de milho (grupo OM - controles), $\beta$ caroteno (grupo BC) ou vitamina A (grupo VA) por 8 semanas consecutivas, durante a fase de progressão da hepatocarcinogênese...... 


\section{ABREVIATURAS}

2-AAF - 2-acetilarninofluoreno

AP-1 - proteina afivadora 1

ARAT - acil-coenzima A retinol-aciltransferase

$\mathrm{BP}$ - benzo[a]pireno

BrDU - bromodesoxiuridina

CDK - quinase dependente de ciclina

CRABP - proteína ligadora de ácido retinóico celular

CRBP - proteina ligadora de retinol celular

DEN - dietilnitrosamina

DMBA - dimetilbenzantraceno

$\mathrm{DMH}$ - dimetilhidrazina

DMSO - dimetilsulfóxido

EGF - fator de crescimento epidermal

yGT - gama-glutamiltranspeptidase

GST-P - glutationa-S-transferase placentária

HGF - fator de crescimento do hepatócito

HMGCOA - 3-hidroxi-3-mejiglutatil coenzima A

4-HPR - 4-hidrofenil retinamida

IGF-1 - fator de crescimento insulina simile 1

LRAT - lecitina-retinol-aciltransferase

3'-MDAB - 3'-metil-4-dimetilaminoazobenzeno

MNNG - N'-metil- $N$ '-nitro- $N$-nitrosoguanidina

MNU - metilnitrosouréia

4-NQO - 1-óxido de 4-nitroquinolina

ODC - ornitina descarboxilase

PBS - solução salina tamponada com fosfato

PCA - ácido perclórico

PPAR - receptor ativado proliferante de peroxissomos

RAR - receptor para o ácido retinóico

RARE - elemento de resposta ao receptor para o ácido retinbico

RBP - proteina ligadora de retinol

$\mathrm{RH}$ - modelo do "hepatócito resistente"

$R X R$ - receptor para o retinóide $X$

RXRE - elemento de resposta ao receptor para o retinóide $X$

$S A M$ - S-adenosil- $L$-metionina

TNF- $\alpha$ - fator alfa de necrose tumoral

TPA - acetato de tetradecanoilforbol

TR - transtiretina 


\section{RESUMO}

\section{EFEITOS DAS ADMINISTRAÇŌES DE $\beta$-CAROTENO E VITAMINA A EM RATOS WISTAR NA ETAPA DE PROGRESSĀO DO MODELO DE HEPATOCARCINOGÉNESE DO "HEPATOCITO RESISTENTE"}

Avaliou-se neste estudo os efeitos das administrações de $\beta$-caroteno e vitamina $A$ em lesões pré-neoplásicas e neoplásicas, na proliferaçăo celular e na metilação dos protooncogenes c-Ha-ras e c-myc, bem como do gene para a enzima HMGCoA redutase, em ratos Wistar na etapa de progressão da hepatocarcinogênese. Para tanto, submeteu-se os animais ao modelo do "hepatócito resistente" que consiste na aplicaçăo do carcinogênico iniciante dietilnitrosamina (DEN), seguida de administrações de 2-acetilaminofluoreno e de uma hepatectomia parcial, para seleçāo/promoção. Dez meses após aplicação da DEN administrouse em três diferentes grupos de ratos $\beta$-caroteno $(7 \mathrm{mg} / 100 \mathrm{~g}$ de peso corpóreo), vitamina $\mathrm{A}$ (1 $\mathrm{mg} / 100 \mathrm{~g}$ de peso corpóreo) ou óleo de milho (controles), respectivamente, por inuubação gástrica e em dias alternados, durante oito semanas. Ao término desse periodo os animais foram sacrificados, administrando-se, entretanto, uma hora antes desse procedimento 5-bromo2-desoxiuridina (BrOU - $10 \mathrm{mg} / 100 \mathrm{~g}$ de peso corpóreo) para avaliação da proliferação celular. Ao exame macroscópico do figado nessa ocasião, constatou-se que as administrações de $\beta$ caroteno e de vitamina A reduziram a incidência de cânceres $(25 \%)$ em comparação ao grupo controle $(62,5 \%)$, embora apenas o retinóide tenha reduzido concomitantemente a incidência e 0 número total de nódulos persistentes de hepatócitos. Estes resultados foram confirmados pelo exame histopatológico (H\&E) de cortes de figado. A morómetria das lesōes pré-neoplásicas marcadas pela enzima $\gamma$-glutamiltranspeptidase ( $\gamma G T)$ não revelou diferenças significativas entre os grupos. Além disso, as aplicações de $\beta$-caroteno e vitamina A reduziram a proliferação celular, tanto nas lesões hepáticas (nódulos persistentes/cânceres), como nos tecidos a seus redores. Observou-se, ainda, hipometilação dos genes c-myc e para a HMGCoA redutase em nódulos de hepatócitos e cânceres, que não foi influenciada pelo tratamento com o carotenóide ou 0 retinóide. A administraçăo de $\beta$-caroteno aumentou as concentrações hepáticas do carotenóide, mas não de refinol, o que sugere a existência de uma ação intrínseca do $\beta$ caroteno, independente de sua função como pró-vitamina A. Conclui-se ainda que tanto o carotenóide como o retinóide apresentam efeitos inibitórios em lesões neoplásicas quando administrados na etapa de progressão da hepatocarcinogênese. Isto poderia envolver uma inibição da proliferação celular no caso das duas substâncias, mas não alguma ação no processo de metilação do DNA. 


\section{INTRODUÇÃO}

A carcinogênese consiste em um processo prolongádo, de múltiplas etapas, e que possibilita, portanto, que sejam tomadas medidas adequadas visando-se evitar, em úláma instância, a manifestaçāo clínica da doença.

A forma mais adequada de se lidar com qualquer enfermidade é através de sua prevenção, sendo isto especialmente verdadeiro para o cåncer. Todavia, um dos grandes problemas na prevenção do mesmo reside no fato de suas causas serem desconhecidas em mais de 50\% dos casos (WATTENBERG, 1997). Mesmo sendo estas conhecidas, existem muitas vezes, entretanto, sérias dificuldades para se removê-las.

A medida que não se pode ainda lidar de forma eficaz com as causas do câncer, outras estratégias passam consequentemente a merecer maior consideração, como por exemplo a possibilidade de sua quimioprevenção átavés de micronutrientes ou substâncias não-nutritivas presentes nos alimentos (REDDY, 1996).

Esse conceito de que a doença pode ser prevenida ou postergada por constituintes naturais da alimentação se originou, em parte, graças a inúmeras evidências epidemiológicas que demonstraram no decorrer dos últimos anos a existência de uma associação inversa entre uma maior ingestāo de frutas e hortaliças e uma reduçāo no risco para o desenvolvimento do câncer em diversos sitios (WORLD CANCER RESEARCH FUNDIAMERICAN INSTITUTE FOR CANCER RESEARCH, 1997a).

Tais achados estimularam a realização de pesquisas voltadas para a identificação dos compostos presentes nos alimentos e que seriam responsáveis pela redução desse risco.

Entretanto, por ocasiāo da avaliação da eventual atividade inibitória de anticarcinogênicos químicos é importante que se procure estabelecer inicialmente, em animais de experimentação, em que etapas do processo carcinogênico estas substâncias estariam atuando predominantemente. Torna-se critico nesse caso, obviamente, o emprego de modelos experimentais adequados e que propiciem justamente uma distinção e sincronizaçăo dessas diversas etapas.

Esse tipo de contecimento, bem como o esclarecimento dos possiveis mecanismos envolvidos com os efeitos quimiopreventivos dos anticarcinogênicos possibilitam que se estabeleça as bases teóricas para suas posteriores utilizaçỏes no ser humano, de forma isolada ou, inclusive, até conjuntamente (DRAGSTED ef al., 1993).

Nos últimos anos teve-se a oportunidade de avaliar em nosso grupo de pesquisa, a atividade quimiopreventiva do $\beta$-caroteno e da vitamina $A$ em ratos submetidos ao modelo do "hepatocito resistente" (RH), um dos poucos protocolos de hepatocarcinogênese já descritos na literatura (WU e MORENO, 1998) capaz de produzir lesōes pré-neoplásicas (focos e nódulos) e neoplásicas de forma sincronizada.

Observou-se, logo de inicio, que o $\beta$-caroteno era capaz de inibir o desenvolvimento de focos e nódulos precoces de hepátocitos quando aplicado durante 8 semanas consecutivas em ratos Wistar submetidos ao modelo do RH. Esta atividade ocorria predominantemente por ocasião da administração do carotenóide previamente à etapa de iniciação do processo carcinogênico, embora também se pudesse constatar certa inibição quando aplicado na fase de seleçãolpromoção inicial da hepatocarcinogênese (MORENO et al., 1991).

Uma outra constatação importante desse experimento foi de que esta ação inibitória ocorreu de forma mais intensa quando o $\beta$-caroteno foi administrado continuamente durante as 8 semanas consecutivas, do que ao ser simplesmente aplicado antes da iniciação ou durante a etapa de seleção/promoçāo do processo carcinogênico (MORENO et al., 1991). 
A seguir, em um outro estudo procurou-se avaliar em ratos Wistar submetiodos ao modelo do $\mathrm{RH}$, a eventual atividade quimiopreventiva da vitamina $\mathrm{A}$ em comparação à do carotenóide, não se tendo constatado ação inibitória digna de nota por parte do retinol, ao contrário do $\beta$-caroteno, na prevenção do desenvolvimento de focos e nódulos de hepatóciłos, por ocasião de sua administração continua por 8 semanas consecutivas em periodo que abrangia concomitantemente as etapas de iniciação e seleção/promoção inicial da hepatocarcinogênese (MORENO et al., 1995a). Isto demonstou ainda in vivo, a existência de uma atividade intrinseca do $\beta$-caroteno independente de sua função como pró-vitamina $A$.

Além disso, como se houvesse também descrito anteriormente na literatura em diferentes modelos experimentais, que carotenóides e retinóides pareciam bloquear o desenvolvimento de eventos neoplásicos atuando principalmente na etapa de promoção da carcinogènese (GERSTER, 1995; LOTAN, 1996), procurou-se avaliar, posteriormente, também em ratos Wistar submetidos ao modelo do $\mathrm{RH}$, as atividades quimiopreventivas do $\beta$-caroteno e da vitamina $A$ quando administrados especificamente durante a fase de promoção inicial da hepatocarcinogènese. Observou-se, neste caso, e mais uma vez, ação inibitória digna de nota no desenvolvimento de focos e nódulos de hepatócitos por parte do carotenóide, mas não do retinóide (RIZZI et al., 1997).

Desta forma, os resultados desses diversos experimentos possibilitaram que se chegasse à conclusão de que o $\beta$-caroteno apresenta atividade quimiopreventiva, atuando não só e principalmente na iniciação como agente bloqueador da carcinogènese, mas também apresentando atividade como anticarcinogênico supressor graças à sua atividade demonstrada na etapa de promoçāo inicial da hepatocarcinogênese.

Tais resultados foram confirmados por algumas de nossas investigações subsequentes (DAGLI et al., 1998; FIORIO, 1998; OLIVEIRA, 1998), bem como por outros estudos descritos na literatura e que empregaram, inclusive, diferentes modelos de hepatocarcinogênese e outras linhagens de ratos (SARKAR et al., 1994, 1995a, 1995b; TSUDA et al., 1994; GRADELET et al., 1997, 1998; HE et al, 1997).

Todavia, são escassas as referências a respeito de experimentos descrevendo a ação do $\beta$-caroteno quando administado especificamente durante a etapa de progressão da hepatocarcinogênese.

Da mesma forma, em relação à atividade da vitamina $A$ na hepatocarcinogênese, os relatos além de pouco frequentes são ainda conflitantes, em muito dependendo das condições experimentais empregadas.

Recentemente, tivemos também a oportunidade em nosso grupo de pesquisa, de avaliar o efeito da administração de vitamina A por 8 semanas consecutivas, em ratos Wistar que se encontravam na etapa de progressão do modelo do "hepatócito resistente" (SILVEIRA, 1998). 0 exame histopatológico do figado dos animais revelou, nesse caso, menor número de lesões neoplásicas benignas e malignas hepatocitárias no grupo de animais tatado com acetato de retinila do que no respectivo grupo controle, o que sugeriu que a vitamina $A$ apresenta um efeito anticarcinogênico supressor quando aplicada especificamente em fase tardia da hepatocarcinogênese.

Devido à sua significância, seria interessante que se confirmasse os resultados desse experimento.

Portanto, procurou-se no presente estudo avaliar em ratos Wistar submetidos ao modelo do "hepatócito resistente", os eventuais efeitos inibitórios do $\beta$-caroteno e da vitamina A quando administrados por 8 semanas consecutivas, agora durante fase desse modelo considerada propicia ao desenvolvimento de cânceres, ou seja, durante a etapa de progressão da hepatocarcinogênese. 
Dentre vários mecanismos já descritos como estando mais diretamente envolvidos com a atividade quimiopreventiva de anticarcinogênicos quando por ocasiāo da administração durante a etapa de progressāo da carcinogênese (KELLOFF et al., 1996), devido às suas estreitas relaçōes com a carcinogênese, decidiu-se também por avaliar concomitantemente nessas condiçōes experimentais as atividades do $\beta$-caroteno e da vitamina $A$ na proliferação celular, bem como no padrão de metilação do DNA, mais especificamente dos proto-oncogenes c-Ha-ras e c-myc e do gene que codifica para a enzima hidroximetilglutaril coenzima A redutase (HMGCoA redutase), genes estes cujos produtos também se encontram reconhecidamente relacionados de forma mais direta com o processo de proliferação celular. 


\section{REVISÃO DA LITERATURA}

\subsection{Cåncer}

É provável que o câncer sempre consistiu em uma doença do ser humano e de animais, sendo conhecido desde a antiguidade. Assim, evidências de câncer foram encontradas em humanos mumificados e em fósseis de óssos de animais, bem como em escritos médicos datando do periodo do Egito antigo. Hipocrates, por exemplo, descreveu doenças que provavelmente consistiam em cánceres do estômago, reto, mama, útero, pele e de outros sítios (WORLD CANCER RESEARCH FUNDIAMERICAN INSTITUTE FOR CANCER RESEARCH, 1997b).

Entretanto, as taxas de incidência de cánceres, bem como os padrões de ocorrência de diferentes cânceres, eram desconhecidos até épocas relativamente modernas. Desta forma, documentos médicos do século dezoito até à primeira metade do século vinte sugerem que a incidência de câncer aumentou com a urbanizaçāo, apesar de parte deste aumento aparente poder ser atribuida a uma maior sobrevida das populações e a um melhor diagnóstico. Na verdade, registros globais confiáveis foram apenas iniciados na segunda metade deste século, com 0 estabelecimento de arquivos relativos ao câncer (WORLD CANCER RESEARCH FUND/AMERICAN INSTITUTE FOR CANCER RESEARCH, 1997b).

Nesse sentido, a Agência Internacional de Pesquisa do Câncer (IARC) estimou que em 1996 ocorreram no mundo mais de dez milhões de casos novos, e que 7 milhões de indivíduos morreram de câncer (OMS, 1997). Em homens, os oito cânceres mais comuns em ordem de incidència săo hoje em dia o de pulmão, estômago, de cólon e reto, próstata, boca e faringe, figado, esôfago e de bexiga. Em ordem de mortalidade, os de pulmão e estômago continuam sendo o primeiro e segundo, respectivarnente, seguidos pelos cánceres de figado, cólon e reto, esòfago, boca e faringe, próstata e, a seguir, os linfomas. Já em mulheres, os oito cânceres mais comuns em ordem de incidência são hoje em dia: o de mama, cérvix, cólon e reto, estômago, pulmão, de boca e faringe, ovário e de endométrio. Em ordem de mortalidade, também nas mulheres esta é diferente: os de mama e estômago são seguidos pelos cânceres de pulmão, cólon e reto, cérvix, càncer primário de figado, de esófago e de boca e faringe.

Nesse mesmo ano, 1996, os doze cânceres com maior mortalidade no mundo foram os de pulmão, estômago, fígado, cólon e reto, esôfago, mama, boca e faringe, cérvix, próstata, bexiga, ovário e endométrio. Acredita-se que todos estejam relacionados à alimentação, incluindo o de pulmāo, e, è claro, com o consumo de cigarros (OMS, 1997).

A predomináncia de cânceres no mundo economicamente em desenvolvimento contrasta com aquela do já economicamente desenvolvido, embora o câncer de pulmão seja hoje em dia o mais comum em ambos. Assim, países da África, América Latina e Ásia apresentam em comum, taxas relativamente elevadas de cânceres do trato aerodigestivo superior, de estômago, figado e cérvix, enquanto paises da Europa, América do Norte e Australásia têm em comum, taxas relativamente elevadas de cânceres de cólon e reto, mama, próstata e de endométrio (WORLD CANCER RESEARCH FUNDIAMERICAN INSTITUTE FOR CANCER RESEARCH, 1997b).

Comparada com a América Central, a América do Sul apresenta taxas mais elevadas de cânceres de esôfago, estômago, colorretal, pulmão (homens) e de mama, mas taxas semelhantes de cânceres de pulmão (mulheres) e de próstata. As incidências dos cânceres de esôfago e de estômago na América do Sul são mais elevadas do que aquelas de populaçōes brancas da América do Norte, mas as taxas dos cânceres colorretais, de pulmão, mama e de próstata são baixas. Além disso, uma comparação entre as frequências relativas de 1983 a 1987 
dos dez cânceres mais comuns em registros de São Paulo, Brasil, e Cali na Colômbia, demonstra que em homens o cáncer de pulmão apresenta uma proporçāo semelhante nas duas populações, embora os cânceres de estômago e próstata contribuam mais para o câncer em homens em Cali do que em São Paulo. Dentre as mulheres, o câncer cervical responde por $22 \%$ de todos os cânceres em Cali, mas apenas por 13\% em Sảo Paulo, enquanto o câncer de mama responde por $24 \%$ de todos os cânceres em mulheres (WORLD CANCER RESEARCH FUNDIAMERICAN INSTITUTE FOR CANCER RESEARCH, 1997b).

\subsection{Carcinogênese}

Carcinogênese é um termo geral utilizado para se denotar o desenvolvimento da neoplasia (PITOT e DRAGAN, 1991). Esta pode ser entendida como um aumento autônomo do número de células, independente de estímulos por fatores extracelulares tais como hormônios, ao contrário da hiperplasia, que por definição consisłe na proliferação de células tecido-específicas, dependente de tais fatores de estimulação (BANNASCH، 1986; BANNASCH e ZERBAN, 1990).

Existem duas amplas classificações das neoplasias (ou neoplasmas), que podem ser benignas ou malignas. As primeiras se referem a neoplasias que apresentam uma proliferação celular localizada e circunscrita exercendo pressão nos tecidos adjacentes, mas que não ultrapassam suas divisas. Em contraste, neoplasmas malignos ou cânceres, tèm a capacidade de invadir e se multiplicar em diferentes partes do organismo, inclusive à distância de seus locais de origem (SMUCKLER, 1983).

Assim, a definição de uma pré-neoplasia deve incluir etapas prévias do desenvolvimento de neoplasmas tanto benignos como malignos. Portanto, uma pré-neoplasia não é idêntica a um pré-câncer, podendo ser descrita em nível histológico, como populaçóes de células fenotipicamente alteradas e que não apresentam natureza neoplásica óbvia, mas que têm possibilidade de progredir para neoplasmas benignos ou malignos (BANNASCH, 1986).

A maioria das doenças exibe períodos ou fases clínica e biologicamente distintas durante suas patogêneses. Isto é especialmente verdadeiro em relação à neoplasia. Assim, observações epidemiológicas e experimentais indicam que o câncer se desenvolve em múltiplas etapas, 0 que compreende, frequentemente, grande parte da vida das diferentes espécies (FARBER e CAMERON, 1980; MOOLGAVKAR, 1986; PITOT, 1993).

Desta forma, enquanto há alguma discussāo quanto ao número exato das múltiplas fases da carcinogênese tanto em humanos como em outos vertebrados, existem evidências substanciais de que a neoplasia pode se desenvolver em très etapas básicas, denominadas, respectivamente, de iniciação, promoção e progressão (FEARON e VOGELSTEIN, 1990; PITOT, 1993; YOKOTA e SUGIMURA, 1993).

Este conceito implica em que as células malignas se desenvolvem a partir das normais, via populações celulares intermediárias consideradas pré-fases do câncer, ou seja, através de alteraçōes ocorrendo em pré-neoplasias.

Portanto, nosso entendimento inicial quanto aos eventos biológicos que acontecem durante o periodo de latência da neoplasia, se deve a estudos pioneiros conduzidos por diversos investigadores na década de 40 deste século, estudando a carcinogênese de pele em coelhos e camundongos (ROUS e KIDD, 1941; BERENBLUM e SHUBIK, 1947). Estas investigaçōes demonstraram a existência de ao menos duas etapas distintas da carcinogênese, denominadas de iniciação e promoçăo. 
Já na década seguinte, FOULDS (1954), investigando o desenvolvimento de cânceres mamários em camundongos, utilizou o termo progressão para se referir a todo o processo que compreende a carcinogênese, após ocorrência do evento da iniciação.

Mais recentemente, uma compreensão das caracteristicas das fases de iniciação e promoçăo, resultou em um modelo sequencial em três etapas para a carcinogênese, consistindo, respectivamente, da iniciação, promoção e progressão (MOOLGAVKAR, 1986; DRAGAN et al., 1993)

Assim, a etapa de iniciação caracteriza-se por alteração irreversivel bioquímica ou molecular, bem como hereditária, da célula, frequentemente acompanhada por "fixação" da mesma por um ciclo de proliferação celular, enquanto a promoção resulta na proliferação clonal, comumente reversivel, de alguns grupos dessas celulas iniciadas. Já algumas características da progressão incluem uma instabilidade progressiva do cariótipo e autonomia aumentada da proliferação celular (FARBER e SARMA, 1987; FARBER e RUBIN, 1991; DRAGAN et al., 1995; PITOT et al., 1996).

\subsubsection{Proliferação, Apoptose e Diferenciação Celular}

O tamanho nomal de um órgão é regulado por um equilíbrio dinâmico entre a divisão e a perda celulares, esta última normalmente através de apoptose. Um desequilibrio nesses componentes resultará em crescimento do órgão, por hipertrofia elou hiperplasia, ou em atrofia. Em geral, não ocortendo morte do organismo, tanto o aumento da replicação celular como da apoptose ocorrem por um tempo limitado, findo o qual se estabelece uma nova homeostasia, resultando em aumento ou diminuição do tamanho do órgāo. Entretanto, esta nova condição é mantida em niveis diferentes daqueles anteriormente presentes no órgão normal. Tal alteração pode afetar a forma com que este responde a agressões adicionais, como por exemplo a exposiçāo a hormônios ou outras substâncias químicas, ou mesmo resultar em risco significativamente maior de desenvolvimento de sequelas como o câncer (FOSTER, 1997).

Indubitavelmente, é axiomático que a proliferação celular desempenha um papel importante, e até mesmo crítico, nas diversas etapas da carcinogênese de vários órgãos e tecidos, ou seja, na iniciaçāo, promoção e progressão (TOMATIS, 1993; FARBER, 1995). Nestes casos, a proliferação celular seria importante, por constituir parte integral do processo de conversāo de adutos do DNA em uma mutação, por ser um fator capaz de aumentar a frequência de mutaçōes através de indução de erros na replicação do DNA, bem como por reduzir o tempo em que pode ocorrer reparo do DNA e ser tamberm importante fator na determinação da relação dose-resposta para alguns carcinogênicos (DOUGLAS et al., 1988; TOMATIS, 1993).

O aumento da divisão celular (mitogênese) pode ser desencadeado tanto por agentes exógenos, como por exemplo carcinogênicos quimicos genotóxicos e até mesmo os promotores da carcinogênese, como por agentes e fatores endógenos, estes incluindo radicais livres de oxigênio produzidos pela respiração, fagocitose e injủria celulares, a despurinização do DNA inerente à sua instabilidade química em solução, e alterações no sistema de reparo do DNA (LOEB, 1989; AMES e GOLD, 1990; AMES et al., 1995).

Entretanto, sabe-se que nem todos os agentes capazes de induzir a proliferação celular estāo necessariamente envolvidos com a carcinogênese e que tecidos com taxa mais elevada de proliferação celular, como por exemplo o intestino delgado, não apresentam maior risco de desenvolvimento de câncer (TOMATIS, 1993; FARBER, 1995). 
Assim, se a proliferaçāo celular per se constitui, na verdade, um fator de risco, é ainda motivo de debates na literatura (FARBER, 1995; CORRESPONDENCE, 1996).

Um outro fator importante no controle do tamanho final de um órgão consiste na morte celular por apoptose, algumas vezes também denominacia de morte celular programada, ativa ou fisiológica. Esta consiste em um tipo de morte celular distinto morfológica, bioquimica e molecularmente da necrose, e que serve para eliminar células em excesso ou indesejáveis de tecidos embrionários, durante a involução de órgãos e na regressāo de neoplasmas. Assim, a apoptose é reconhecida hoje em dia, como um fenômeno de ampla ocorrência em biologia, e que é complementar, mas se opõe à proliferação celular, no sentido de preservar a homeostasia tecidual (BURSCH et al., 1994; UEDA e SHAH, 1994; COLUMBANO, 1995).

Trata-se, na verdade, de um programa geneticamente codificado, e que pode ser modulado por uma série de fatores incluindo os de crescimento, mediadores intracelulares da transdução do sinal e proteinas nucleares que regulam a expressão gênica, a replicação do DNA e o ciclo celular. Estes diversos fatores e vias convergem, provavelmente, em etapas finais comuns, resultando em seu fenótjpo característico (FISHER, 1994).

Desta forma, este complexo programa pode também estar potencialmente alterado em células neoplásicas, conferindo às mesmas uma vantagem de sobrevivência. Até o momento não existem, entretanto, evidências diretas quanto a um papel da apoptose na patogenia da carcinogênese, embora proto-oncogenes tais como bcl-2 e myc, bem como anti-oncogenes do tipo 053 , que regulam a apoptose, tenham sido implicados com a progressāo ou regressão, respectivamente, do desenvolvimento de neoplasmas (FISHER, 1994). É então possivel que a apoptose resulte na eliminaçāo de células portadoras de genes "cancerosos" e reprima o desenvolvirnento de neoplasias, enquanto uma falha nesta poderia culminar na progressão das mesmas. Aftemativamente, a apoptose poderia desencadear a progressão de neoplasias, afetando a passagem pelas diversas etapas do cicto celular (UEDA e SHAH, 1994; HUNTER, 1997).

A diferenciação tem também um importante papel na biologia das células e está integralmente envolvida com o controle da prolíferação das mesmas. Da mesma forma que a carcinogênese, esta também consiste em um processo que se desenvolve em múlipplas etapas e afeta diversos processos biológicos. Assim, células cancerosas apresentam uma série de alteraçōes na diferenciação, comumente associadas com a expressão aberrante de protooncogenes do tipo c-jun e junB elou anti-oncogenes. Por outro lado, evidências indicam que processos dependentes de diferenciação podem mediar a expressāo de resistência à carcinogênese e induzir as células cancerosas a reverterem a um estado benigno, sem perda de seus potenciais proliferativos (TZEN ef al., 1988; SCOT, 1997).

\subsubsection{Agentes Capazes de Induzir a Carcinogênese}

Pode-se considerar a carcinogênese corno um processo ativo induzido em organismos vivos por uma série de diferentes agentes químicos ou fisicos, que podem ser agrupados em quato categorias distintas, ou seja, aqueles responsáveis pela carcinogênese biológica, física, química ou genética (PITOT e DRAGAN, 1991).

Tanto na carcinogênese biológica como genética o agente carcinogênico consiste de Macromoléculas com peso molecular relativamente elevado, o DNA ou RNA, responsáveis por transmissão de informação. Em contrapartida, a carcinogênese por radiação pode ser consequência das ações diretas ou indiretas de fótons de elevada energia ou particulas, sobre o DNA existente. Jà no caso da carcinogênese atribuivel a muitas substâncias quimicas de menor 
peso molecular, isto pode ou não envolver a ação direta do composto quimico com o DNA celular, ou mesmo seu metabolismo a uma forma ativa, que pode, então, reagir com o DNA, produzindo uma alteração permanente em sua estrutura (PITOT e DRAGAN, 1991).

\subsubsection{Carcinogênese Química}

A história do estudo da carcinogênese quimica tem seu inicio praticamente três séculos atrás, quando RAMAZINI apư HAZELWOOD (1987) reconheceu, em 1700, que o câncer de mama em freiras poderia ser atribuido ao estilo de vida das mesmas (RAMAZINI, 1940), e quando HILL apud HAZELWOOD (1987), em 1761, observou a ocorrência frequente de câncer nasofaringeano em homens que aspiravam cronicamente tabaco em pó (HILL, 1761). Foi entretanto POTT (1775) apud HAZELWOOD (1987) quem descreveu pela primeira vez um exemplo de carcinogênese química, reconhecendo que a incidência aumentada de câncer de escroto em limpadores de chaminé, poderia ser atribuida à exposição frequente da pele à fuligem do carvão.

Apesar da existência de muitas formas de câncer, foi justamente o de pele que recebeu a maior atenção por parte dos experimentalistas da época. Todavia, não foi senão em 1915, após as tentativas de inúmeros investigadores, que YAMAGIWA e ICHIKAWA (1915) apud HAZELWOOD (1987) tiveram sucesso em produzir experimentalmente neoplasias de pele, após repetidas aplicações tópicas de alcatrão do carvão em orelhas de coelhos. Subsequentemente, este foi fracionado, identificando-se o 1,2,5,6-dibenzantraceno como sendo o primeiro carcinogênico sintético (KENNAWAY e HEIGER, 1930). Um resumo da história de tais estudos, bem como referências adicionais podem ser encontrados na revisão de GREENWALD e GREENWALD (1983) apud HAZELWOOD (1987).

Desde então, a lista de substâncias químicas suspeitas ou comprovadamente carcinogênicas para animais de experimentação e o ser humano, não cessou de aumentar no decorrer deste século. Já em uma revisão publicada em 1949, CONKLIN apud HAZELWOOD (1987) listou uma grande variedade de associaçōes entre produtos/processos industriais e o câncer. Além de discutir os respectivos papéis da radiação ionizante e ultravioleta, de agentes biológicos tais como virus e bactérias, de substâncias inorgânicas como 0 arsênico, asbestos, cromatos e o berílio, o autor descreve uma impressionante lista de compostos orgânicos incluindo a anilina e corantes azo, estrógenos, hidrocarbonetos aromáticos policíclicos, alcatrões, óleos, creosoto e o benzeno, dentre outros.

Entretanto, uma questão intrigante da carcinogênese química na época, era como se correlacionar a diversidade da natureza das inúmeras substâncias químicas e seus respectivos efeitos biológicos, com suas consequências finais, ou seja, o câncer. Este problema foi em parte resolvido graças aos estudos de MILLER e MILLER $(1966,1971)$, que em face a suas observaçōes propuseram a hipótese de que a maioria dos carcinogênicos químicos deveria ser ativada a intermediários eletrofilicos, isto é, compostos capazes de adquirirem elétrons durante reaçōes quimicas, que reagiriam, a seguir, com sitios nucleofilicos-átomos que doam elétrons, como por exemplo, o N-2, N-7 e 0-6 da guanina-presentes em componentes celulares, estabelecendo, desta forma, um ponto comum de atuação dos carcinogênicos.

Destas observaçōes surgiu, portanto, o conceito de que existem carcinogênicos diretos ou indiretos (ou pró-carcinogênicos), que devem ser convertidos em carcinogênicos definitivos, bem como carcinogênicos próximos, ou seja, aqueles intermediários metabólicos entre os pró-carcinogénicos, moléculas estas na verdade ainda inativas, e os 
carcinogênicos definitivos, eletrofilicos que em última instância reagem com Macro e micromoléculas presentes na célula (VENITT, 1994).

Exemplos de carcinogênicos diretos, ou seja, aqueles que não parecem requerer qualquer conversão prévia a metabólitos mais reativos e que constituem uma minoria, são as nitrosamidas (alquil nitrosouréia), o bis(cloro) metil éter e a mostarda nitrogenada. Por outro lado, aminas aromáticas do tipo do 2-acetilaminofluoreno e 2-naftilamina, hidrocarbonetos aromáticos policiclicos (como por exemplo o benzopireno), as aflatoxinas, o cloreto de virila, nitrosaminas e nitro-compostos aromáticos ou heterociclicos do tipo dos nitrofuranos, constituem prócarcinogênicos, ativáveis por reações de oxidação principalmente no sistema das monoxigenases do figado, ou de redução, hidrólise, ou de conjugação (FARBER, 1981; VENITT, 1994; DIPPLE, 1995).

Assim, os compostos eletrofilicos produzidos a partir dos carcinogênicos podem interagir com sítios nucleofilicos presentes em MACromoléculas celulares como o DNA, RNA, proteínas e polissacaridios, bem como em pequenas moléculas como a glutationa, aminoácidos e nucleotideos (MAGEE e FARBER, 1962; MILLER e MILLER, 1966; RAJALAKSHMI et al., 1982; PITOT e DRAGAN, 1991).

A capacidade dos carcinogênicos de se ligarem aos ácidos nucléicos foi demonstrada pela primeira vez in vivo por MAGEE e FARBER (1962). A partir dessa observação, reconhece-se, hoje em dia, que a maioria deles reage quimicamente com o DNA através da transferência a esse ácido nucléico, de residuos alquila (nitrosaminas, aflatoxinas, nitrosouréias, mostardas), arilamina (aminas aromáticas, amidas, corantes azo) ou aralquila (hidrocarbonetos aromáticos policiclicos, alcalóides pirrazolidinicos), formando, deste modo, produtos estáveis conhecidos como adutos (VENTT, 1994; DIPPLE, 1995). Estes variam em tamarho e complexidade, podendo formar ligações entre bases adjacentes da mesma cadeia (ligações cruzadas intra-cadeia) ou entre as duas cadeias (ligações cruzadas inter-cadeias) do dupléx do DNA, resultando em substituição, deleção e adição de bases e consequentemente, em mutações pontuais (VENITT, 1994).

A formação de adutos é característica de substâncias genotóxicas. Portanto, carcinogênicos com essa propriedade são conhecidos como genotóxicos, sendo capazes de produzir modificação genética.

Após o insulto causado pelo agente genotóxico, as lesões no genoma celular distribuem-se heterogeneamente, refletindo a capacidade dessas substâncias de se direcionarem a sequências especificas ou regiões do genoma (BOHR et al., 1994). Assim, as evidências sugerem que genes individuais, como o p53, que desempenha importante papel na manutenção da integridade do genoma (SUN et al., 1995), são mais sensiveis à lesão genotóxica, dependendo de suas sequências, de sua estrutura fisica na cromatina e de seu estado quanto à transcrição e replicação.

Exemplos seriam o benzo[a] pireno, que produz tipicamente mutações $G \rightarrow T$ que afetam nucleotideos em trechos ricos no dinucleotideo $\mathrm{GC}$ da sequência codificante do gene $p 53$, bem como a aflatoxina B1 que produz prevalentemente mutações do tipo transversões $G \rightarrow T$ na sequência de nucleotídeos do códon 249 , mutações estas observadas frequentemente no gene p53 de carcinomas hepatocelulares humanos, em regiões da Ásia e África (GREENBLATT et al., 1994; COLEMAN e TSONGALIS, 1995).

Em contrapartida, carcinogênicos não-genotóxicos do tipo do dietilhexilftalato, do metapirileno, tetracloreto de carbono, bifenilas polibromadas e do grupo de substâncias conhecidas como agentes proliferadores de peroxissomos, como certos agentes hipolipemiantes do tipo do clofibrato, são aqueles capazes de induzir a carcinogênese, sem entretanto resultar em qualquer modificação estrutura! observável do DNA (REDDY et al., 1980; DOUGLAS et al., 1988; PITOT e DRAGAN, 1991; FOSTER, 1997). 
Assim, carcinogênicos não-genotóxicos podem ser definidos como aqueles compostos que nāo formam adutos de DNA, não induzem reparo do mesmo e apresentam resultados negativos em testes in vitro e in vivo de mutagenicidade (MELNICK, 1992). Nestes casos, a carcinogenicidade geralmente se dá em apenas uin órgăo ou tecido, e frequentemente afeta somente uma das espécies de animais testadas (FOSTER, 1997).

Muitos desses carcinogênicos atuam através de mecanismos epigenéticos, alterando, por exemplo, a expressão gênica e aumentando a proliferação celular, seja por mitogênese direta da população celular alvo, ou por citotoxicidade com consequente proliferaçāo regenerativa (COHEN e ELLWEIN, 1990; BARRETT, 1992; FOSTER, 1997).

Entende-se como uma modificação epigenética, qualquer alteração no fenótipo que não resulte de alguma mudança na sequência do DNA (BARRETT, 1987). Esta pode ser estável e herdável, incluindo alteraçōes na metilação do DNA, ativação transcricional, controle da tradução e modificações pós-tradução, que resultam, em última instância, em modificações da expressão gênica (SMUCKLER, 1983; BARRET, 1987).

Substâncias assim chamadas promotoras de neoplasias, que podem tanto aumentar ou mesmo serem necessárias à carcinogênese desencadeada por determinado carcinogênico (DRINKWATER, 1990), e que frequentemente não sāo mutagênicas, atuam, em geral, através de mecanismos epigenéticos, talvez por uma ação prolíferativa celular constante (AMES e GOLD, 1990; FOSTER, 1997), com ou sem mutaçס̃es curnulativas (AMES e GOLD, 1990; TRAVIS e BELEFANT, 1992), evocando eventos que poderiam inativar alelos de anti-oncogenes (SCRABLE et al,, 1990), ou mesmo por interaçōes mediadas entre o promotor e receptores (WEINSTEIN, 1988; PITOT, 1995).

Desta forma, a estimulação da proteína quinase $C$ desencadeada por certos ésteres de forbol, constitui exemplo clássico de promoção epigenética (DRINKWATER, 1990), em contraste com outros promotores que podem inibir fosfatases de proteinas (HAYSTEAD et al., 1989), ou mesmo atuar através de mecanismos ainda obscuros.

\subsubsection{Metilação do DNA}

Concomitantemente com as quatro principais bases, o DNA da maioria dos organismos contém uma ou mais bases que ocorrem com menor frequência na cadeia do ácido nucléico, sendo a mais comum destas a 5 -metilcitosina $(5 \mathrm{mC})$. Estima-se que no DNA de vertebrados 3 a $6 \%$ das citosinas se encontram metiladas, principalmente na sequência do dinucleotideo CPG, cuja distribuição na cadeia está longe de ser aleatória, e ocorrendo principalmente nas regiões 5 ' de diversos genes (ADAMS, 1990).

Esta principal modificação epigenética de bases do DNA de mamiferos, ou seja a metilação da citosina, ocorre graças à atividade de uma enzima específica, a DNA (citosina-C5) metiluansferase (EC 2.1.1.37), que é capaz de transferir grupamentos metila $\left(\mathrm{CH}_{3}\right)$ a partir do doador universal S-adenosil-L-metionina (SAM ou Adomet) ao átomo C5 da citosina, com a consequente produção de resíduos 5mC (ADAMS, 1990; MAZIN, 1993).

Trata-se de um processo que se desenvolve por ocasião do ciclo celular tanto durante a sintese do DNA como após a replicação do mesmo, isto é, em duas etapas, com um dos máximos da metilação do DNA coincidindo com a fase $S$ (de sintese do DNA) e o outro com a mitose ou com as fases G2 ("gap" 2) ou G1 ("gap" 1) (MAZIN, 1993).

Este compreende uma modificaçāo especifica no DNA, envolvendo, provavelmente, a formação intermediária de uma ligação covalente do mesmo com a enzima. Durante a replicação 
do DNA a fita parental retém as bases modificadas, mas a fita filha se encontra, inicialmente, não-metilada. Portanto, o DNA nesta forma, e neste instante, é conhecido como hemimetilado, ate que ocorra a transferência dos gruparnentos metila para a fita filha. Nesse interim acontecem reaçōes que necessitam da presença de sítos hemimefilados no DNA nascente, tais como reparo de despareamento, segregação cromossômica e expressão de alguns genes (ADAMS, 1990).

A metilação da citosina resulta em diversas modificações biofisicas no DNA, podendo, por exemplo, aumentar a temperatura de fusão do DNA "nu", influenciar a extrusāo de estruturas cruciformes, bem como a transição da forma B para a forma $Z$ do mesmo e, desta maneira, modular a atividade enzimática de alguns dos componentes envolvidos com importantes eventos de manutenção da integridade do genoma de células de mamíferos, tais como a ligação de extremidades, um processo não-homólogo em que quebras do DNA são religadas, e a recombinação homóloga (ZACARIAS, 1993; LIANG e JASIN, 1995).

Além disso, funcionalmente a metilaçāo do DNA desempenha um papel crítico na regulação da transcrição e, portanto, da expressão gènica, tendo sido implicada, por exemplo, tanto com o estabelecimento como com a manutençāo da inativação do cromossomo $X$, bem como com padrões de impressão genômica e com a diferenciação celular (RAZIN e CEDAR, 1991; RAZIN e CEDAR, 1994).

Assim, as consequências da metilaçāo da citosina na regulação gênica podem refletir alterações diretas ou indiretas na capacidade de ligação ou ativação de fatores de transcrição e proteinas da cromatina (ADAMS, 1990; RAZIN e CEDAR, 1991; ZACARIAS, 1993).

Desta forma, numerosos estudos estabeleceram correlações, in vitro e in vivo, entre um padrão de hipometlação da região promotora de genes virais ou celulares com o respectivo aumento das expressões dos mesmos, da mesma forma que diversos experimentos demonstraram que a metilação pode reprimir a tanscrição gênica (DOERFLER, 1983; BIRD, 1992).

Descreve-se, ainda, que alteraçōes no padrão de metilação do DNA podem também desempenhar importantes papéis na carcinogênese, constituindo um de seus primeiros e mais comuns eventos (COUNTS e GOODMAN, 1995).

Portanto, hipometilação geral do genoma e de genes especificos, bem como hipermetilação localizada em determinadas regiōes do DNA (ilhas de CpG), constituem achados característicos observados no decorrer do processo carcinogênico, podendo, inclusive, causar alteraçōes significantes na expressão gênica também neste caso (FEINBERG e VOGELSTEIN, 1983a; GAMA-SOZA ef al., 1983; JONES, 1987; LAIRD e JAENISCH, 1994).

De fato, descreveu-se que a hipometilaçāo de oncogenes se encontra associada com o aumento de suas expressōes, tendo sido ainda observada em algumas sequências repetitivas e genes diretamente relacionados com o desenvolvimento de neoplasmas malignos (COUNTS e GOODMAN, 1995; USHIJIMA et al., 1997).

Nesse sentido, baseando-se na observação da ocorrência de hipometilaçāo de determinado sitio do oncogene raf constatada logo nas etapas iniciais da hepatocarcinogênese em camundongos e, posteriormente, de que esta se mantinha também por ocasião do surgimento dos carcinomas, sugeriu-se que a hipometilação poderia constituir um dos fatores cruciais envolvidos com a etapa da promoçāo, e que facilitaria, eventualmente, a expansāo clonal de células progenitoras que resultariam, em última instância, em neoplasias malignas (COUNTS e GOODMAN, 1995).

A hipótese de que a hipometilação do DNA constitui um evento também importante durante a etapa de iniciaçāo do processo carcinogênico, foi reforçada por experimentos realizados com o agente hipometilante 5-azacitidina, tendo-se relatado que este análogo da citidina foi capaz de ativar genes previamente inativos e de potenciar a iniciação da hepatocarcinogênese por agentes químicos (JONES et al, 1982; DENDA et al., 1985). 
Por outro lado, a hipermetilação de regiões especificas do DNA poderia estar relacionada com a inativação de anti-oncogenes ou mesmo com uma maior presença de mutações no DNA, inclusive nos próprios anti-oncogenes, em consequência da desaminação da $5 \mathrm{mC}$ em uracila e formação de transições $\mathrm{C} \rightarrow \mathrm{T}$. Assim, a hipermetilação regional foi associada, por exemplo, com a inibição da expressão do anti-oncogene retinoblastoma, e com a ocorrência de uma elevada porcentagem de mutações observada nos dinucleotideos $C p G$ do gene $P 53$ em casos de câncer colorretal (FEARON e JONES, 1992; MAZIN, 1993; COUNTS e GOODMAN, 1995).

Descreve-se ainda que a hipermetilação poderia também influenciar a carcinogênese, mais especificamente sua etapa de iniciação, através de uma inibição do reparo do DNA com consequente fixação de uma lesão promutagênica (COUNTS e GOODMAN, 1995).

\subsubsection{Proto-oncogenes e Anti-oncogenes}

As células neoplásicas possuem, tipicamente, numerosas mutações genômicas e aberrações cromossômicas, incluindo mutações pontuais, amplificações e deleções gênicas, bem como erros de replicação. A aquisição de tal instabilidade do genoma pode representar uma etapa inicial no processo da carcinogênese, comprometendo proteínas envolvidas, por exemplo, com a replicação e reparo do DNA, com a progressão pelo ciclo celular, bem como diversos outros componentes do complexo arranjo bioquímico responsável pela manutenção da homeostasia celular normal (COLEMAN e TSONGALIS, 1995).

Assim, acredita-se que o fenótipo maligno se desenvolva em consequência de um acúmulo de mutações em genes que desempenham um papel crítico no controle da divisão, crescimento e diferenciação celular, acúmulo este acompanhado por uma série de alterações histopatológicas, através das quais o epitélio normal progride para a neoplasia benigna e, subsequentemente, para a maligna (FEARON e VOGELSTEIN, 1990; VENITT, 1994).

Um exemplo bem documentado desse processo é o câncer colorretal (FEARON e VOGELSTEIN, 1990), cujo desenvolvimento se acompanha de eventos mutagênicos cumulativos em duas principais classes de genes, os proto-oncogenes e os anti-oncogenes, que estão intimamente envolvidos com o controle da sinalização célula-célula, com a divisão celular e a apoptose (BARRETT, 1993).

Portanto, cada uma das sucessivas alterações genéticas no processo de carcinogênese conferiria vantagens seletivas de crescimento à população de células afetadas (FEARON e VOGELSTEIN, 1990), sendo que a capacidade proliferativa aumentada das células alteradas estaria associada com uma tendência aumentada de ocorrerem mutações no DNA, o que poderia contribuir para a progressão do fenótipo transformado (COHEN e ELLWEIN, 1990; 1991).

A asscciação entre proliferação celular e aumento da susceptibilidade à mutação pode refietir a necessidade de replicação do DNA para produzir mutação permanente nos sítios genômicos lesados (COLEMAN e TSONGAI_IS, 1995). Entretanto, é também possivel que algum evento molecular prévio da carcinogênese, torne as células predispostas a mutações no DNA estável (LOEB, 1994).

A existência de uma terceira classe de genes, envolvida com maior predisposição ao câncer, foi postulada face à descoberta de um gene no cromossomo 2, associado a um risco aumentado para o câncer colorretal não-polipósico hereditário (AALTONEN et al., 1993; PELTOMÄKI et al., 1993). Sugeriu-se que este tipo de genes poderia predispor ao câncer os individuos afetados, graças a uma instabilidade genética talvez atribuivel a alterações de revisão durante a replicação do DNA (AALTONEN et al., 1993). 
Desta forma, os genes cujas funçōes normais ou patológicas podem influenciar as etapas do desenvolvimento neoplásico de uma forma positiva ou negativa, podem ser classificados como proto-oncogenes, anti-oncogenes (ou genes supressores de "tumores", oncogenes recessivos ou ainda emerogenes) e genes moduladores, que podem influenciar proprievades importantes mas secundárias de neoplasmas malignos, tais como a invasividade, propriedade de metastatizar ou capacidade de gerar uma resposta imune (KLEIN, 1987).

A descoberta dos oncogenes se relaciona com as pesquisas do inicio do século quanto a vírus relacionados com o câncer, estimuladas pelos desenvolvimentos na época, da microbiologia e da epidemiologia das doenças infecciosas (VARMUS, 1989).

Os primeiros oncogenes a serem identificados foram aqueles de vírus relacionados com o câncer, sendo portanto denominados de oncogenes virais ( $\mathrm{v}$-onc) (HUEBNER e TODARO, 1969). Logo se descobriu, entretanto, que esse número relativamente pequeno de genes de vírus, estava também representado em células normais de mamiferos. Assim, utilizando sequências de oncogenes virais como sondas gênicas, estudos de hibridização com transferência tipo Southem de DNAs genômicos de células de mamíferos, revelaram a existência de genes correspondentes, denominados de proto-oncogenes celulares (c-onc). Além disso, análises de genes c-onc e v-onc possibilitaram a conclusāo de que proto-oncogenes constituiam, na verdade, genes normais, codificantes para proteinas envolvidas com mecanismos celulares de transdução do sinal, empregados na manutenção do crescimento e desenvolvimento da célula normal (BISHOP, 1987; VARMUS, 1989; BISHOP, 1996).

Sabe-se então que oncogenes conhecidos de DNA virus, constituem partes integrais do genoma viral requerido à replicação dos vírus. Por outro lado, os oncogenes de retrovirus são genes celulares nomais ou ligeiramente modificados, que sáo ou apropriados pela célula hospedeira ou nela ativados (LODISH et al., 1995). De fato, genes v-onc devem ter surgido durante a evolução, por integração no genoma viral de uma cópia de um proto-oncogene normal.

Quanto às funçōes das proteinas codificadas por esses proto-oncogenes envolvidos com a proliferação e desenvolvimento da célula normal ou com sua tansformação por agentes fisicos, químicos ou virais (BISHOP 1996), estas podem atuar como fatores de crescimento, receptores para fatores de crescimento, transdutores intracelulares do sinal ou como fatores de transcrição (BISHOP, 1991; WALKER e RAPLEY, 1997). Nāo é surpreendente, portanto, que alguma alteração, ou "afivaçäo", de proto-oncogenes, possa estar relacionada com a carcinogênese.

Análises bioquímicas e de biologia molecular comparativas entre os oncogenes virais e os proto-oncogenes, sugeriram que os últimos devem ter sofrido diversas alteraçōes, incluindo deleções e mutações, por ocasião de seus processos de transdução para os genomas virais. Assim, o potencial carcinogênico do oncogene viral foi atribuido a essas alteraçōes. Estes achados resultaram, inclusive, no conceito de "afivação" de proto-oncogenes celulares como base da carcinogénese não-viral, dando ainda suporte à teoria oncogênica do câncer, proposta por HUEBNER e TODARO (1969).

A ativação de proto-oncogenes no processo neoplásico pode ocorrer ao nivel transcricional e resultar em aumento da expressāo, podendo ser mediada por: (i) inserção de promotorlestimulador ("mutagênese por inserçăo"), como por exemplo, em c-mos, c-erbB, c-myb, c-myc e c-Haras; (ii) translocação, por exemplo em MYC, observada no linfoma de Burkitt; (iii) rearranjo gênico, por exemplo RET e TRK, em carcinomas de tireóide; (iv) amplificaçāo génica, por exemplo L-MYC e N-MYC, em tumores sólidos do tpo carcinomas de pulmão, onde esta pode ser constatada como anormalidades cromossômicas, incluindo as assim chamadas "regiões de coloração homogênea", e DNA extracromossômico denominado "minuto duplo"; e finalmente, (v) por mutaçäes pontuais que afetam a estrutura e integridade funcional de seus produtos codificados, como por exemplo em Ha-RAS, em carcinomas de cólon, pulmāo e pâncreas (BISHOP, 1987; 1991). 
Por outro lado, como seus próprios nomes sugerem, os anti-oncogenes estāo envolvidos com a inibição da expressão do fenótipo maligno, podendo ser inativados durante o processo da carcinogênese também por mutaçōes pontuais, perda ou deleção cromossômica, recombinação somática ou conversāo gênica (VENITT, 1994). Exemplos de antj-oncogenes relacionados com neoplasias humanas, algumas delas inclusive hereditárias por envolverem mutações em células germinativas, são o RB1, associado com o retinoblastoma, osteosarcoma e carcinomas de mama, bexiga e pulmão; o P53, relacionado com o astrocitoma, osteosarcoma e os carcinomas de mama, cólon e pulmão; o WT1, com o tumor de Willms, e o DCC, associado com o carcinoma de cólon (BISHOP, 1991; PONDER, 1992).

Como a patogênese por esses genes se deve à perda de suas funções normais, inferiu-se que estes poderiam servir como repressores de funçóes bioquímicas e da proliferação celular (SAGER, 1989). Assim, existem evidências circunstanciais de que o produto do anti-oncogene RB1 pode servir como uma espécie de freio para a passagem das células das etapas G0/G1 do ciclo celular para a fase $S$, e de que o tpo selvagem do anti-oncogene p53 ectópico pode inibir a proliferação de células de carcinoma colorretal, cujos genes P53 são defeituosos (BAKER et al, 1990; HOWE ef al., 1990).

Além disso, estudos demonstram que o anti-oncogene P53, que se encontra mutado em mais da metade dos cânceres humanos em paises ocidentais, estáa envolvido com o controle da apoptose (YONISH-ROUACH et al., 1991), em resposta a agentes como a radiação ionizante e mutagênicos químicos. Como uma célula morta não pode passar adiante uma mutação, sugere-se que a célula que contém um alelo mutante desse anti-oncogene é mais capaz de sobreviver a um insulto genômico do que uma célula normal, sendo portanto mais provável de resistir a uma mutação no outro alelo do $p 53$, devido à sua menor propensão para sofrer apoptose. Mutação em um dos alelos desse anti-oncogene e perda do outto, são frequentemente observadas em células cancerosas (LANE, 1993).

Portanto, células cancerosas acumulam frequentemente modificações genômicas decorrentes de sequência de eventos que podem resultar na ativação cumulativa de aranjos particulares de proto-oncogenes e inativaçăo de anti-oncogenes, com consequentes atteraçöes nos mecanismos normais de controle da proliferação, da apoptose e da diferenciação celular, processos estes também intimamente relacionados com a carcinogênese (SCHMANDT e MLLS, 1993).

\subsection{Hepatocarcinogênese}

O câncer primário de figado inclui o carcinoma hepatocelular, responsável por $90 \%$ de todos os casos, bem como o angiossarcoma, colangiocarcinoma e o hepatoblastoma, correspondendo no mundo ao sexto câncer mais comum e à terceira causa mais frequente de mortalidade por câncer. Assim, estima-se que em 1996 foram diagnosticados cerca de 540.000 novos casos, correspondendo a $5,2 \%$ de todos os casos novos de câncer no mundo. Nesse mesmo ano, estimou-se ainda que a mortalidade atribuivel ao cáncer primário de figado foi de 536.000 pessoas, correspondendo a 7,5\% de todas as mortes por câncer (OMS, 1997).

As taxas desse câncer são em geral bem mais comuns em sociedades em desenvolvimento, compreendendo mais de $80 \%$ dos casos globais e respondendo a China por cerca de mais da metade de todos os casos. É quase sempre fatal, e a incidência em homens é maior do que o dobro do que a de mulheres (WORLD CANCER RESEARCH FUNDIAMERICAN INSTIIUTE FOR CANCER RESEARCH, 1997C).

As infecções pelos virus das hepatutes $B(\mathrm{HBV})$ e $\mathrm{C}(\mathrm{HCV})$ consistem na causa predominante do câncer primário de figado, que quase sempre se desenvolve em um figado 
cirrótico. Além disso, em figados não-cirróticos è encontrado em cerca de $20 \%$ dos portadores assintomáticos do HBV e raramente em pacientes tomando androgênicos-anabólicos ou esteróides contraceptivos orais (FIEL ef al., 1996). Outros fatores de risco incluem o consumo excessivo de bebidas alcoólicas e de cigarros, baixa ingestão de vegetais, ingestāo de arsênico inorgânico, exposição ao dióxido de tório radioativo, sobrecarga de ferro e exposição a aflatoxinas (CHEN et al., 1997; KEW ot al, 1997; MONTESANO et al. 1997; WORLD CANCER RESEARCH FUNDIAMERICAN INSTITUTE FOR CANCER RESEARCH, 1997c).

No Estado do Rio de Janeiro, em período compreendido ente 1979 a 1981, a mortalidade por câncer hepático ocupou $05^{\circ}$ lugar em relaçăo a todos os demais cânceres e foi cerca de 8 vezes mais elevada do que na cidade de São Paulo (PINTO e COLEMAN, 1990), o que confirma a existência de grandes diferenças regionais em relaçăo à mortalidade por este tipo de câncer, também em nosso pais.

Estas observações indicam uma etiologia multifatorial para a hepatocarcinogênese humana, que também ocorre através de um processo em múltiplas etapas, envolvendo, provavelmente, interações genéticas e ambientais (CHEN et al, 1997).

O padrão de desenvolvimento da neoplasia maligna do figado em rałos é semelhante ao que se observa em seres humanos (FARBER e SARMA, 1987; BENNER et al., 1997). Desta forma, modelos de hepatocarcinogênese química em ratos vêm sendo considerados dentre os melhores para o estudo da gênese e desenvolvimento in vivo de neoplasmas (HUFF, 1993; GRASL-KRAUPP et al., 1994).

Isto se deve, em grande parte, à susceptibilidade desse órgão à indução de cânceres, a seu tamanho e grande acúmulo de conhecimentos nos últimos anos em relação à sua biologia, bioquímica, patologia e aspectos moleculares, bem como à facilidade de manipulaçāo de seus diferentes estágios de proliferação celular.

Diversos modelos foram descritos para o estudo da hepatocarcinogênese quimica. A maior parte utiliza um carcinogênico genotóxico como agente iniciador, tendo sido as nitrosaminas, micotoxinas ou aminas aromáticas, os compostos mais usados. Além disso, em vários protocolos a primeira fase da evolução dos hepatócitos já iniciados é estimulada por breve ou prolongada exposição a um ambiente que selecione estas células para um crescimento diferenciado (promoção) (FARBER e SARMA, 1987; FARBER e RUBIN, 1991).

Os modelos experimentais de hepatocarcinogênese se caracterizam por apresentar antes do surgimento do câncer hepático, proliferaçōes de hepatócitos consideradas ainda préneoplásicas, pois não parecem ter algum grau de crescimento autônomo, designadas por focos e nódulos de hepatócitos, e neoplásicas, respectivamente.

Os focos e nódulos de hepatocitos podem ainda ser denominados de precoces e persistentes, dependendo do periodo após aplicação do agente iniciante em que se sacrifica os animais, e que precedem o aparecimento do câncer primário de figado (FARBER, 1982; BANNASCH e ZERBAN, 1990). Por convenção, denomina-se de focos de hepatócitos às lesões menores do que um lóbulo hepático, enquanto o termo nódulos de hepatócitos é aplicável a lesōes geralmente esféricas, ocupando área equivalente a um ou vários lóbulos hepáticos (SQUIRE e LEVIT, 1975).

De acordo com critérios morfológicos e citoquímicos os focos de hepatocitos podem ser classificados em: claros, acidofilicos, vacuolados, intermediários, mistos, basofilicos, tígróides e anfofilicos (BANNASCH e ZERBAN, 1990). Estes representariam, com exceçāo dos tigróides e anfofilicos, etapas sucessivas de uma sequência ordenada de alterações celulares, progredindo dos focos apresentando predominantemente células claras ricas em glicogênio ou acidofilicas, para focos de hepatócitos com populaçōes celulares intermediárias mistas e basofilicas, culminando em nódulos (adenomas) e carcinomas hepatocelulares (ZERBAN et al., 1994). 
Além disso, estas expansões celulares clonais podem ser distinguidas das células normais aos seus redores, por alteraçōes nas expressōes de várias enzimas incluindo a adenosina trifosfatase (ATPase), glicose-6-fosfatase, $\gamma$-glutamiltanspeptidase ( $\gamma G T$ ) e glutationa-S-transferase placentária (GST-P), que comumente são utilizadas corì marcadores para suas identificaçōes, bem como avaliação de seus números e dimensōes através de análise de imagem computadorizada (FARBER e SARMA, 1987; DRAGAN e PITOT, 1992; DRAGAN et al., 1997; IMAl et al., 1997).

Apesar de produzirem muitas vezes elevada incidência de neoplasmas malignos, nem todos os modelos de hepatocarcinogênese, entretanto, são úteis à avaliação do processo carcinogénico, justamente por não resultarem em sincronização do aparecimento das lesōes precursoras. Esta sincronia tem grande importância, pois a análise sequencial de qualquer processo em múltiplas etapas, seja ela molecular, bioquímica, genética ou biológica, necessita um sistema sincronizado se existe intenção de se estabelecer uma relaçāo precursor-produto, em cada uma das principais etapas (FARBER, 1995).

\subsubsection{Modelos Experimentais de Hepatocarcinogênese Química}

Em 1935, foi descrito o primeiro modelo de carcinogênese hepática em ratos, ufilizandose o carcinogênico o-aminoazotolueno em exposição continua, por longo período (SASAKI e YOSHIDA, 1935). A ausência de sincronia e a dificuldade de se discernir as diversas etapas da carcinogênese, tornaram-no útil apenas para ensaio da carcinogenicidade de substâncias encontradas por exemplo nos alimentos e em outos meios. Outra desvantagem desse protocolo de hepatocarcinogénese é a geração de nódulos de hepatócitos muitas vezes pequenos.

Já em 1965, descreveu-se um modelo de exposiçāo crônica e intermitente a carcinogênicos, como por exemplo o 2-acetilaminofluoreno (2-AAF), que consiste em se submeter os animais por 3 a 4 semanas a uma ração contendo a substância, interrompendb-se o tratamento por 1 a 3 semanas, e repetindo-se o esquema por mais 3 a 4 vezes (REUBER, 1965). Com este protocolo são gerados nódulos grandes de hepatbocitos, muitas vezes utilizados para análises biologicas e bioquímicas. Entretanto, este também não resulta em sincronia no desenvolvimento de neoplasmas malignos.

Um outro modelo de hepatocarcinogênese foi descrito posteriormente, utilizando-se pela primeira vez um carcinogênico iniciador, o 2-AAF, com subsequente aplicação de uma substância promotora, o fenobarbital, o que possibilitou a distinção de duas etapas do processo da carcinogénese (PERAINO et al,, 1971). Este foi subsequentemente modíficado, substituindo-se o 2-AAF como agente iniciador pela dietilnitrosamina (DEN), aplicada 24 horas após a realização de uma hepatectomia parcial a $70 \%$, capaz de induzir intensa prolfferação celular e, provavelmente, de fixar o dano no DNA causado previamente pela DEN (PITOT et al., 1978).

Já o modelo da aflatoxina, descrito em 1973, baseia-se nas propriedades hepatotóxica e hepatocarcinogênica da aflatoxina B1, uma micotoxina produzida pelo fungo Aspergillus flavus (NEWBERNE e ROGERS, 1973a; 1973b). Apesar de resultar em 100\% de incidência de cânceres, este não possibilita, entretanto, distinção entre as múltiplas etapas do processo carcinogênico.

Em 1946, descreveu-se pela primeira vez a atividade hepatocarcinogênica de uma ração deficiente em colina e metionina (COPELAND e SALMON, 1946). Isto despertou interesse, na época, pois os experimentos envolviam a retirada de uma substância da ração, ao invés da adição de carcinogênicos químicos. Entretanto, questionou-se a validade desse modelo, após a 
observação de que as rações poderiam estar, eventualmente, contaminadas com aflatoxina B1 e outros carcinogênicos (NEWBERNE, 1967).

Posteriormente, relatou-se um efeito promotor da hepatocarcinogênese por parte de rações deficientes em colina, quando estas foram administradas por várias semanas após aplicação de carcinogênico iniciador (SELLS et al., 1979). A seguir, tồs laboratórios independentes descreveram quase que simultaneamente a obtenção de carcinomas hepatocelulares em cerca de $50 \%$ dos animais tratados com rações isentas de colina e deficientes em metionina, sem a adição de carcinogênicos (MIKOL, et al., 1983; GHOSHAL e FARBER, 1984a; YOKOYAMA et al,, 1985). A esta altura, confirmou-se exaustivamente a não contaminação das rações com aflatoxina ou outros carcinogênicos.

Portanto, esse modelo é capaz não só de promover como também de iniciar o processo da carcinogênese hepática, embora não fiquem também evidentes as múltiplas etapas da hepatocarcinogênese.

A colina consiste em um amônio quaternário presente nos alimentos. Atua como precursor de fosfolípides e do neurotransmissor acetilcolina, bem como doador de grupamentos metila (após oxidação para betaina). Tentativas no sentióo de se esclarecer os mecanismos envolvidos com a gênese do carcinoma hepatocelular, revelaram que a raçăo deficiente em colina é capaz de produzir alteraçōes no DNA, talvez mediadas por peroxidação lipidica em nivel dos núcleos das células (RUSHMORE et al., 1986; MORENO et al., 1990).

Além disso, sua administração crônica pode resultar em deficiência relativa de grupamentos mefila no figado dos animais, com consequente hipometilação do DNA hepático (WILSON et al., 1984). Se esta estiver, por sua vez, associada a um aumento da expressão do proto-oncogene c-myc, ou mesmo com mutaçāo do anti-oncogene p53, poderia desempenhar um papel na hepatocarcinogênese desencadeada por esse sistema (POIRIER, 1994). Uma outra possibilidade seria o desencadeamento da carcinogênese devido, em parte, a anormalidades presentes na sinalização para proliferação mediada pela proteína quinase $C$, bem como na apoptose celular (ZEISEL et al., 1995).

A partir de 1980, passou-se a descrever que substâncias não-genotóxicas como a nafenopina, clofibrato e fenofibrato, muitas vezes utilizadas como agentes hipolipemiantes em seres numanos, além de certos analgésicos, uricosúricos e poluentes ambientais como os ftalatos, eram também capazes de desencadear a hepatocarcinogênese em roedores, atraves da ocorrência de uma série de alteraçōes hepáticas, em especial a proliferação de peroxissomos, com consequente aumento das atividades de algumas enzimas associadas a essas organelas (REDDY et al., 1980; REDDY e RAO, 1987).

Observou-se que estes compostos devem ser administrados por tempo prolongado e que atuam, basicamente, como promotores da carcinogênese hepática, diferindo, ainda, os focos e nódulos de hepatócitos produzidos com esse modelo em suas expressões fenotipicas, daqueles gerados por outros sistemas de hepatocarcinogênese (KRAUPP-GRASL ot al., 1990).

Seus mecanismos de ação são ainda desconhecidos, embora se descreva que a atividade promotora do câncer possa estar relacionada neste caso a um aumento de produçăo de $\mathrm{H}_{2} \mathrm{O}_{2}$ pelos peroxissomos proliferados, devido a uma indução da $\beta$-oxidação de ácidos graxos (REDDY e RAO, 1987), a uma estimulaçăo da proliferaçāo celular via interaçăo com o receptor ativado proliferante de peroxissomos (PPAR) (GREEN e WAHLI, 1994), ou mesmo a uma alteração na expressão de proteínas relacionadas com o ciclo celular (RININGER ef al., 1997 ).

Já no protocolo de hepatocarcinogênese assim chamado "stop model", descrito em 1982, utiliza-se para a induçåo de carcinomas hepatocelulares e lesões pré-neoplásicas em ratos, 0 carcinogênico $\mathrm{N}$-nitrosomorfolina dissolvido na água dos animais, e administrado durante sete semanas consecutivas. A seguir, estes são sacrificados em periodo variável após término do 
tratamento, tendo-se descrito a obtenção de carcinomas após cerca de 34 semanas de observação (MOORE et al., 1982).

Também em 1982-1983, descreveu-se um outro modelo, o do ácido orótico (COLUMBANO er al., 1982; RAO et al., 1983). Este se baseia na administração dessa substância adicionada às rações dos ratos durante o período de promoção, após iniciação dos mesmos com o carcinogênico 1,2-dimetilhidrazina (DMH). Descreve-se a obtenção de carcinomas hepatocelulares em $100 \%$ dos animais, que manifestaram ainda metastases em $40 \%$ dos casos, tratando-se de protocolo que apresenta boa sincronia no desenvolvimento de focos e nódulos de hepatocitos. Um fato ainda relevante é que nảo se observa nesse modelo, hiperplasia hepática e nem proliferação de células ovais ou de dutos biliares (DENDA ef al., 1994).

0 ácido orótico consiste em um precursor natural da biossintese de nucleotídeos pirimidinicos. Por ocasião de sua administração em excesso, resulta em desequilíbrio do "pool" de nucleotideos, o que poderia causar atteraçōes na replicação e reparo do DNA, mecanismos estes talvez responsáveis pelo desenvolvimento dos hepatocarcinomas (MANJESHWAR et al., 1993).

\subsubsection{O Modelo de Hepatocarcinogênese do "Hepatócito Resistente"}

Dentre os vários protocolos de hepatocarcinogênese existentes para ratos, o modelo do "hepatócito resistente" (RH), descrito em 1976 (SOLT e FARBER, 1976) e modificado em 1987 (SEMPLE-ROBERTS et al., 1987), está bem caracterizado e é suficiente para induzir elevada incidéncia de cânceres.

O sistema consistia, originalmente, na administração única de agente iniciante, a DEN, seguida de procedimento de seleção através do qual se adicionava 2-AAF às rações, em combinação com uma hepatectomia parcial à 70\% (SOLT e FARBER, 1976). Posteriormente, devido a restriç̋es legais em diversos paises quanto à adiçăo de substâncias carcinogênicas às rações dos animais, optou-se pela aplicação intragástrica do 2-AAF (SEMPLE-ROBERTS et al., 1987).

Este tem como característica o fato de produzir as lesões pré-neoplásicas e neoplásicas de forma sincronizada, possibilitando, desta forma, estudos mais detalhados. Seu desenvolvimento baseou-se na hipótese, agora já bastante comprovada, de que diversos carcinogênicos quimicos são capazes de produzir hepatócitos resistentes e um novo fenótipo constitutivo com um padrāo bioquimico attamente caracteristico, um fenótipo resistente, durante a etapa de iniciação do processo carcinogênico, se ocorre um ciclo de proliferação celular.

Tais hepatócitos resistentes podem ser rapidamente estimulados de modo a formarem proliferações focais (focos e nódulos) após breve exposição não iniciante a reduzidas concentrações de alguns carcinogēnicos, tais como o 2-AAF, associada a estímulo mitogênico representado por uma hepatectomia parcial (SOLT e FARBER, 1976; FARBER e SARMA, 1987; FARBER e RUBIN, 1991; LEDDA-COLUMBANO et al., 1992; PITOT et al., 1996).

O 2-AAF, da mesma forma que a grande maioria, se não todos os carcinogênicos genotóxicos, é capaz de inibir a proliferação da maior parte dos hepatócitos nomais, ou seja, dos não iniciados (sensiveis), talvez por um bloqueio na atividade da DNA polimerase, devido à formação de adutos de DNA (GOETHEM et al., 1993). Este não é capaz, entretanto, de inibir os poucos hepatócitos resistentes (DRAGAN e PITOT, 1992; FARBER, 1995) que apresentam, caracteristicamente, atividades das enzimas das fases I e II responsáveis pela metabolização de xenobióticos, diminuidas ou aumentadas, respectivamente (ROOMl et al., 1985). 
A pressão de seleção para gerar focos e nódulos desse modelo é intensa, e as células resistentes proliferam, portanto, de forma sincronizada. Esta sincronia persiste pelas múltiplas etapas de desenvolvimento do processo carcinogênico (FARBER, 1984 a e b; FARBER e SARMA, 1987).

Em diversos protocolos de hepatocarcinogênese a proliferação dos hepatócitos em focos e nódulos é bastante lenta, em geral assincrônica, necessitando muitas semanas, ou mesmo alguns meses, para que se formem nódulos hepáticos visiveis. Já no modelo do $\mathrm{RH}$ isto acontece, ao contrário, de forma rápida e sincronizada, de modo que nódulos precoces já podem ser observados Macroscopicamente em uma ou duas semanas após a etapa de seleção/promoção inicial.

A grande maioria desses nódulos precoces, cerca de 95-98\%, sofre "remodelação", um processo altamente complexo envolvendo mudanças no suprimento sanguineo e em características bioquimicas, bem como da estrutura e arquitetura celulares, retornando ao aspecto "normal" anterior do figado. Uma pequena parte (2-5\%) segue outro caminho, o da persistência. (TATEMATSU et al., 1983; FARBER e RUBIN, 1991; IMAl et al., 1997).

Justamente em nódulos persistentes de hepatócitos é que claramente se conseguiu demonstrar que estes atuam como locais de futura evolução para o câncer. Assim, nódulos persistentes são facilmente obsenáveis ao redor de sete meses após aplicaçāo do agente iniciante, a DEN.

A carcinogenicidade dessa nitrosamina foi demonstada pela primeira vez em 1960 (SCHMÄHL et al., 1960), tendo-se constatado, posteriomente, que esta resulta na formação de diferentes tipos de adutos de DNA, tais como a $0^{2}-0^{4}$-, e $0^{6}$-etiltimidina e a 8-hidroxiguanina (DRAGAN et al., 1994a; NAKAE et al,, 1997), provavelmente responsáveis pela iniciação do processo carcinogênico. Estes nódulos persistentes demonstram sequência progressiva de evolução celular, com a ocorrência de "nódulos em nódulos" e, finalmente, aparecimento de câncer após cerca de 10-11 meses (FARBER et al., 1988).

Quando estudados em detalhe os nódulos apresentam padrões característicos de organizaçāo e estutura celular, arquitetura e histoquímica, sendo bastante diferentes do figado normal em quaisquer de suas etapas de desenvolvimento (OGAWA et al, 1979a; 1979b). Deve-se ressaltar, entretanto, que a pequena população de nódulos persistentes apresenta o mesmo padrão bioquímico observado na maioria dos nódulos que sofre remodelaçāo (nódulos precoces) (FARBER e SARMA, 1987; FARBER, 1990).

Portanto, a maior parte dos nódulos persistentes tem o mesmo padrão de remodelaçāo que a maioria dos nódulos, embora muito mais lento, nāo existindo evidências de que nódulos que se remodelam e aqueles que persistem representem, na verdade, duas respostas inteiramente diferentes à açāo de carcinogênicos (FARBER, 1990).

Nesse sentido, apesar de uma maturação ou reversão fenotípica ter sido previamente susgerida como responsável pelo fenômeno da "remodelação" (KITAGAWA, 1971; KITAGAWA e PITOT, 1975; WILLIAMS, 1980), bem como não se ter podido descartar a possibilidade da acorrência de uma reposiçāo progressiva de hepatócitos crescendo a partir do tecido considerado "normal" ao redor dos nódulos, acreditase, mais recentemente, que este possa envolver, na verdade, a rediferenciação dos hepatócitos dos nódulos para um fenótipo semelhante ao do adulto (TATEMATSU ef al., 1983; FARBER et al., 1988; FARBER e RUBIN, 1991), ou até mesmo a morte e remodelação das células por apoptose (SCHULTE-HERRMANN et al., 1990).

De qualquer forma, a informaçāo para este evento espontâneo, uma expressão genética bastante complexa, parece estar já normalmente inserida no genoma (FARBER et al., 1988; FARBER e RUBIN, 1991; IMAJ et al., 1997). Além disso, acredita-se, ainda, que a persistência dos nódulos talvez indique justamente um bloqueio na remodelação por diferenciação (FARBER 
et al., 1988; FARBER e RUBIN, 1991), podendo estar relacionada com uma maior tendência de evolução para os carcinomas hepatocelulares (OHASHI et al., 1996).

Assim, diversas observações demonstram a existência de uma relação evolutiva entre focos, nódulos e cânceres hepáticos, como por exemplo a presença de associaçāo topográfica entre as várias lesōes (FARBER e CAMERON, 1980; WILLIAMS, 1980; SCHERER, 1987; FARBER, 1990; 1992). Além disso, ao contrário do figado normal, mas de forma semelhante a todos os hepatocarcinomas testados, nódulos hepáticos, na proporção de 1/3, contêrm hepatócitos que expressam capacidade de invasão em ensaio in vitro (DE RIDDER et al., 1987; FARBER e SARMA, 1987).

\subsubsection{Origem Celular do Hepatocarcinoma}

Para alguns autores a sequência evolutiva para o câncer hepático, envolvendo a passagem pelas etapas de focos e nódulos, implicaria a desdiferenciaçào de hepatócitos maduros que reteriam suas capacidades de proliferarem, sem o envolvimento de outos tipos celulares (URIEL, 1976; WILLIAMS, 1980; BANNASCH, 1984; FARBER e SARMA, 1987; PITOT, 1990).

Por outro lado, uma outra hipótese sugere que o processo de iniciação da hepatocarcinogênese ocorreria não no hepatócito maduro diferenciado, que então se desdiferenciaria, mas sim em células "mãe" ("stem cells") ou em suas descendentes imediatas, que originariam neoplasias devido a uma falha em se diferenciarem em células maduras (bloqueio de maturação) (SELL e DUNSFORD, 1989; SELL, 1990; SELL e PIERCE, 1994). Define-se como células "mãe" aquelas células multipotentes que se dividem para produzirem duas outras, sendo que uma permanece como "mãe" e a outra se diferencia e expressa um outo fenótipo. Além disso, caracteristicamente estas respondem através da proliferação à perda celular patológica ou à senescência (SELL, 1990).

Descreve-se que paralelamente aos hepatocitos, um outo grupo de células, o das assim denominadas células "ovais", prolifera em áreas portais do figado durante a hepatocarcinogênese de ratos, camundongos e seres humanos (OPIE, 1944; PRICE et al, 1952; FARBER, 1956; SELL, 1978; HSIA et al, 1994), bem como em resposta a diferentes outros estimulos. O termo inespecíico células "ovais" foi introduzido pela primeira vez por FARBER, em 1956, embora estas já haviam sido anteriormente descritas na literatura (OPIE, 1944; PRICE et al, 1952).

Células "ovais" apresentam núcleos alongados, citoplasma difuso e aparecem precocemente durante o desenvolvimento de vários protocolos experimentais de hepatocarcinogênese, sendo suas origens ainda obscuras. Investigações apontam os colangiolos como sítio de origem das células "ovais" (GRISHAM e HARTROF, 1961; 8ANNASCH e REISS, 1971). Já outos estudos sugerem que estas constutuiriam as próprias células "mãe" (SELL e LEFFERT, 1982; SELL e DUNSFORD, 1989), ou a primeira etapa de diferenciação das mesmas (SIGAL et al., 1992), e que teriam ainda a dupla capacidade de se diferenciarem em células de dutos biliares e em hepatócitos (EVARTS et al., 1987; GERMAIN et al., 1988; TEE et al., 1996).

Desta forma, enquanto alguns autores afirmam que as células "ovais" não desempenham qualquer papel na hepatocarcinogênese (FARBER e CAMERON, 1980; TARSETTI et al., 1993), outros acreditam que a partir destas originar-se-iam focos e nódulos de hepatócitos $e$, posteriormente, o carcinoma hepatocelular ou o colangiocarcinoma (SELL e DUNSFORD, 1989; SELL, 1990; SELL e PIERCE, 1994).

Entretanto, mais recentemente, demonstrou-se em ratos submetidos ao modelo do $\mathrm{RH}$, que focos e nódulos derivam-se de hepatócitos resistentes e não de células ouctulares ovais, 
constituindo estas últimas um compartimento facultativo, independente, de cèlulas "mãe" multipotenciais (ANILKUMAR et al., 1995). Em concordància com estas observações, estudos utilizando técnicas de biologia molecular, sugerem que tanto os hepatócitos como as células "ovais", poderiam, na verdade, dar origem a estes dois tipis de carcinomas hepáticos (BRALET ef al., 1996; PONDER, 1996; PISTOI e MORELLO, 1996).

\subsection{A Relação Alimentaçāo—Nutrição—Câncer e sua Importância}

Apesar de não ser novo o conceito de que a alimentação e o estado nutricional podem influenciar o câncer, até há não muitos anos atrás este tipo de interaçāo recebeu, suprendentemente, pouca atenção por parte da comunidade científica.

Existem relatos de que já YONG-HE YAN, vivendo durante a dinastia Song na China (960-1279 DC), acreditava que uma alimentação deficiente era a causa de uma condição que hoje em dia se acredita ser o câncer de esôfago. Além disso, descreve-se que WISEMAN, em 1676, sugeriu que o câncer poderia ser decorrente de "um erro na alimentação, uma grande acrimônia das carnes e bebidas, associado com uma falha na primeira concoç̧āo (digestão)", recomendando abstenção de "sal e de carnes gordas e temperadas" (WORLD CANCER RESEARCH FUNDIAMERICAN INSTITUTE FOR CANCER RESEARCH, 1997a).

Posteriormente, LAMBE (1815) apud WORL CANCER RESEARCH FUNDIAMERICAN INSTIUTE FOR CANCER RESEARCH, (1997a), ajertou em seu tratado a respeito da alimentação, câncer e outras enfermidades crónicas, contra o perigo do consumo em excesso de alimentos em geral, e de carnes em particular.

Já em 1849, BENNETT apud WORLD CANCER RESEARCH FUNDIAMERICAN INSTITUTE FOR CANCER RESEARCH, (1997a), autor de livros médicos, escreveu que "as circunstáncias que diminuem a obesidade e a tendência de formação de gordura, seriam opostas, a priori, aquelas que resultariam em uma tendência ao câncer".

Por outro lado, no começo deste século SHAW (1907) apud WORLD CANCER RESEARCH FUNDIAMERICAN INSTITUTE FOR CANCER RESEARCH, (1997a), advogou um regime prudente no sentido de se reduzir o risco de desenvolvimento de cânceres, recomendando maior ingestão de alimentos de origem vegetal e menor consumo de alimentos de origem animal, de bebidas alcoólicas e chá, bem como que se procurasse evitar o tabaco.

Da mesma forma, em 1908 WILIAMS apud WORLD CANCER RESEARCH FUNDIAMERICAN INSTITUTE FOR CANCER RESEARCH, (1997a), em seu Natural History of Cancer, concluiu que "provavelmente nenhum fator isolado é mais potente na determinação do desencadeamento do câncer em individuos predispostos do que a alimentaçāo em excesson, propondo, ainda, que "muitas indicações apontam para o consumo voraz de profidios, especialmente carnes". De acordo com esse autor "a falta de exercicios e, provavelmente, de alimentos vegetais em quantidades suficientes" estaria relacionada com o câncer.

Quanto aos primeiros estudos epidemiológicos formais que procuraram avaliar a relaçāo alimentação-câncer, pode-se citar aqueles conduzidos por ORR (1933), que desenvolveu um estudo ecológico do câncer oral na India, e STOCKS (1933), que realizou uma investigaçāo do câncer tjpo caso-controle na Inglaterra e pais de Gales; cada um destes identificou distorções nos padrões alimentares como fatores de risco, especialmente a ingestão reduzida de vegetais e frutas (WORLD CANCER RESEARCH FUNDIAMERICAN (NSTITUTE FOR CANCER RESEARCH, 1997a).

Já o fato de que a alimentação pode influenciar a carcinogênese em animais de experimentaçăo foi pela primeira vez observado em experimentos conduzidos por TANNENBAUM (1940; 1942a; 1942b), em que este demonstrou que camundongos submetidos 
à restrição alimentar apresentavam menor número de tumores cutâneos espontâneos e/ou induzidos por aplicação via dérmica de benzo[alpireno, do que animais alimentados ad libitum. Além disso, o autor constatou que animais alimentados com rações apresentando elevado conteúdo calórico elou ricas em gorduras, tinham maior número de cânceres de mama induzidos por carcinogênicos químicos.

Todavia, um maior interesse pelas causas nutricionais do câncer começou apenas a ocorrer, na verdade, a partir das décadas dos anos 60 s e 70 s deste século.

Desta forma, durante esse período estudos epidemiológicos investigaram o padrão de incidência na população (PERRY, 1975; DOLL, 1977; WYNDER e GORI, 1977), a distribuição demográfica e socioeconômica, os efeitos da migração (HAENSZEL e KURIHARA, 1968; HAENSZEL et al., 1972; WEISBURGER e RAINERI, 1975; KAGAWA, 1978) e hábitos alimentares em diferentes grupos populacionais (PHILLIPS, 1975), possibilitando que se chegasse à conclusão que fatores nutricionais desempenhavam, efetivamente, importante papel na etiologia e, inclusive, na preveção de cânceres (COMMITTEE ON DIET, NUTRITION AND CANCER; NATIONAL RESEARCH COUNCIL, 1982).

Assim, algumas observações e publicaçōes merecem ainda destaque devido às suas importantes contribuições e repercussōes para o maior conhecimento e desenvolvimento do estudo da relação alimentação-nutrição-câncer na época, como por exemplo o fato de se ter constatado elevação das taxas de cânceres de cólon e mama em japoneses migrantes para os EUA, o que reflete a influência do meio ambiente na carcinogênese, incluindo a alimentação (WYNDER e SHIGEMATSU, 1967), e de que a incidência da maioria dos cânceres, se não todos, varia grandemente entre paises e regiōes. Esta última observação fez, inclusive, com que se concluisse (HIGGINSON e MUIR, 1973; DOLL, 1977) que " 80 a $90 \%$ dos cânceres se devem a fatores externos, sendo, portanto, teoricamente preveniveis".

Em concordância com essas estimativas WYNDER e GORI (1977) propōe, subsequentemente, em uma revisão, que o "potencial de se prevenir" todos os cânceres seria efetivamente de $80-90 \%$, sugerindo, ainda, que o fator alimentação responderia por $40 \%$ de todos os casos de cânceres em homens e $60 \%$ em mulheres, e que as causas alimentares do câncer incluiriam, em geral, uma hiperalimentaçāo, bem como gorduras e carnes em excesso.

Um marco, entretanto, para essa área do conhecimento, foi a revisão de DOLL e PETO, publicada em 1981, onde esses epidemiologistas ingleses sugerem que seria plausivel se reduzir em 35\% (com uma variação de 10 a 70\%) a mortalidade por câncer nos EUA, através de modificações a serem realizadas na alimentação.

Como íatores protetores esses autores ressaltaram os papéis de vitaminas antioxidantes, de vegetais ricos nesses compostos, e de microconstituintes dos alimentos, como por exemplo, indóis e inibidores de proteases. Fibras, ou alimentos que tornam as fezes volumosas foram também citados como importantes. Além disso, aspectos da alimentação mencionados como possiveis causas de câncer foram o consumo de alimentos em excesso (cânceres de útero e vesícula biliar em mulheres), as gorduras (cânceres de mama, cólon e reto) e carnes (cânceres de cólon e reto). Causas consideradas relativamente sem importäncia seriam os aditivos alimentares (corantes e adoçantes), contaminantes (excluindo-se a aflatoxina em relação ao câncer hepático) e métodos de preparação e armazenagem capazes de produzirem carcinogênicos. Dez anos mais tarde DOLL (1992) reviu suas conclusōes, continuando a afirmar que "a estimativa de que o risco de câncer fatal pode ser reduzido em $35 \%$ através de modificações na alimentação, continua a ser razoável".

Desta forma, o COMMITTEE ON DIET, NUTRITION AND CANCER, organizado pelo NATIONAL RESEARCH COUNCIL em 1982, e baseado em resultados de investigações epidemiológicas e experimentais disponiveis até então, propôs recomendações "compativeis 
com uma boa prática nuticional e provavelmente capazes de reduzirem o risco de câncer". Estas incluiam a redução da ingestão de gorduras para 30\% do total de calorias, a inclusảo de frutas, vegetais e cereais integrais na alimentação diária, e a recomendação para se minimizar o consumo de alimentos salgados e defumados, bem como o de bebidas alcoólicas.

Recentemente, os dados epidemiológicos e experimentais acumulados na literatura desde então, relativos à interação alimentação, nưrição e câncer, foram revisados e analisados por inúmeros pesquisadores e consultores de diversos paises, o que deu motivo, inclusive, a uma publicaçāo que reflete, sem dúvida, a importância dessa área do conhecimento na atualidade e a que se fizesse, dentre outras, a seguinte recomendaçăo: que se deve reconhecer, inclusive as autoridades governamentais competentes, que a incidència de câncer no mundo pode ser reduzida em 30-40\%, através de alterações adequadas na alimentação e em determinados estilos de vida (WORLD CANCER RESEARCH FUNDIAMERICAN INSTITUTE FOR CANCER RESEARCH, 1997d).

\subsection{Quimioprevenção do Câncer e Anticarcinogênicos dos Alimentos}

A quimioprevenção do câncer, definida pela primeira vez em 1976 por SPORN e colaboradores, pode ser considerada uma forma de se prevenir a doença, através da administração de um ou mais compostos químicos durante as etapas iniciais pré-neoplásicas da carcinogênese, ou seja, na fase de iniciação ou promoção, e antes do estabelecimento da etapa de progressão (SPORN et al., 1976; WATTENBERG, 1985; ALBERTS e GARCIA, 1995; HONG e SPORN, 1997; PEZZUTO, 1997).

Em primeira instância, o método mais adequado de se eliminar o impacto do câncer em seres humanos é através da prevenção. Nesse sentido, o grupo inicial de medidas visando-se alcançar esse objetivo consiste na remoção dos agentes etiológicos, ou seja, na prevençāo primária do câncer (WATTENBERG, 1985; HENDERSON et al., 1991; STATLAND, 1992; AMES et al., 1995; PEZZUTO, 1997).

Em alguns casos isto é possivel, como por exemplo, em relação ao fumar. Em outras situaçōes, entretanto, torna-se, muitas vezes um objetivo dificilmente alcançável, como é o caso das lesões do DNA, proteinas e lipides, desencadeadas por exposição a produtos oxidantes endógenos decorrentes do metabolismo normal, sugeridos como potenciais agentes causadores de cânceres (AMES, 1983; AMES et al., 1995; SLAGA, 1995). Além disso, vale lembrar que as causas de mais de $50 \%$ das neoplasias malignas do ser humano são ainda desconhecidas (WATTENBERG 1997).

Assim, o desenvolvimento de uma segunda linha de prevenção, baseado na quimioprevençāo, adquire caráter de excepcional importância (WATTENBERG, 1985; SHARMA et al., 1994; ALBERTS e GARCIA, 1995; ARNOLD ef al, 1995; HONG e SPORN, 1997; WATTENBERG, 1997 ).

Nesse sentido, pode-se conceber, em principio, dois tipos básicos de quimioprevençāo. $O$ primeiro, voltado principalmente para o fornecimento de agentes quimiopreventivos aplicáveis a grandes grupos populacionais, ou seja, podendo culminar, inclusive, com medidas de Saúde Pública em grande escala. As substâncias, nestes casos, deveriarn por excelência apresentar toxicidade bastante reduzida, como se observa, por exemplo, com determinados inibidores presentes nos alimentos, tais como os carotenóides e em especial o $\beta$-caroteno (PEZZUTO, 1997; GESCHER et al., 1998).

O segundo tipo de estratégia quimiopreventiva estaria direcionado a individuos considerados em "alto risco", devido a predisposições genéticas como a polipose adenomatosa 
familiar, ou maior exposição a carcinogênicos, como por exemplo, fumantes (KELOFF et al., 1992; ARNOLD et al., 1995; EL-BAYOUMY et al., 1997; WATTENBERG, 1997). Outras populações alvo incluiriam individuos portadores de lesőes reconhecidamente pré-cancerosas, como por exemplo displasia cervical, e pacientes previamente trarados por câncer através de quimioterapia elou radioterapia (KELOFF et al., 1992; MORSE e STONER, 1993; HONG e SPORN, 1997).

A medida que o risco de desenvolvimento de câncer aumenta, os compostos maís provavelmente eficazes seriam aqueles que suprimem a evolução do processo neoplásico. Nestes casos poder-se-ia até tolerar, talvez, substâncias que apresentassem maior toxicidade, como é o caso dos retinóides (KELLOFF et al., 1992; MORSE e STONER, 1993).

E grande o número de compostos até agora identificados com eventual atividade quimiopreventiva contra o câncer (WATTENBERG, 1985; BOONE et al, 1990; MORSE e STONER, 1993; SHARMA ot al., 1994; ARNOLD et al., 1995; ALBERTS e GARCIA, 1995; PEZZUTO, 1997; STONER ef al., 1997). Esta diversidade quimica pode ser um fator positivo, pois indica que diversas abordagens poderão ser empregadas visando-se a prevenção, além de possibilitar mais opçōes para a seleção dos agentes mais indicados a cada caso.

Além disso, não se deve esquecer da complexidade da carcinogênese, e de sua evolução prolongada e diversificada. Quanto mais complexo e prolongado o processo patológico, maior o número de possibilidades de se empregar medidas capazes de interromper sua ocorrência final (KELLOFF et al., 1992; ALBERTS e GARCIA, 1995; HONG e SPORN, 1997).

Diversos dos inibidores da carcinogênese até agora identificados sāo constituintes naturais dos alimentos (DRAGSTED et al., 1993; AMES et al., 1995; EL-BAYOUMY et al., 1997; GESCHER et al., 1998).

Portanto, a investigação dos mecanismos através dos quais a alimentação influencia o câncer, está não só contribuindo para a elucidação de aspectos fundamentais da carcinogénese e do comportamento biológico das neoplasias malignas, como também pode ter ainda um grande impacto em estratégias de prevenção (ROGERS et al., 1993; AMES et al., 1995).

Nesse sentido, a capacidade de substâncias influenciarem as diversas etapas da carcinogênese pode ser usada para se estabelecer uma classificação de anticarcinogênicos, e esta ser empregada como fundamento teórico para a seleção de compostos a serem utilizados em seres humanos (DRAGSTED et al., 1993).

Desta forma, baseado em grande parte na ocasião ou periodo em que agentes quimiopreventivos exibem atividade em modelos de carcinogênese em animais de experimentação, anticarcinogénicos podem ser classificados como inibidores, bloqueadores ou supressores, sendo que os primeiros teriam a capacidade de inibir a formação dos carcinogênicos, os bloqueadores a etapa de iniciaçăo da carcinogênese, enquanto os agentes supressores atuariam durante as fases de promoção/progressão (WATTENBERG, 1983; 1985; 1996; MORSE e STONER, 1993; STONER ef al., 1997). Durante a investigaçāo de vários anticarcinogênicos tornou-se ainda evidente que alguns compostos atuam em mais do que em uma das etapas da carcinogênese (WATTENBERG, 1985; 1990).

Um exemplo clássico de inibição da carcinogênese ałravés da prevençāo da formação de carcinogênicos, é o uso de ácido ascórbico para prevenir a formação de nitrosaminas a partír de aminas secundárias ou amidas e nitritos, no ambiente ácido do estômago (WATTENBERG, 1985; 1990; BERTRAM et al., 1987; MORSE e STONER, 1993; STONER et al., 1997).

Por outro lado, exemplos de anticarcinogènicos bloqueadores seriam compostos organossulfurados do tipo dissuifeto de dialila, presentes no alho, monoterpenos corno o D-limoneno encontrados em frutas citicas, ou carotenóides como o $\beta$-caroteno, presente ern frutas $e$ hortaliças (WATTENBERG, 1990; MORSE e STONER, 1993). Estes anti-iniciadores podem atuar através de diversos mecanismos, incluindo a prevenção da formaçāo, captação ou 
ativação de carcinogênicos, bem como através da prevenção da alteração genética inicial ou reparação aumentada da lesão do DNA (DRAGSTED et al., 1993; MORSE e STONER, 1993).

Já anticarcinogênicos supressores que apresentam a capacidade de inibir ou retardar a promoção/progressāo poderiam inibir a proliferação de células iniciadas ou ativar a diferenciação celular através de vários mecanismos, tais como a antioxidação, interação com receptores celulares ou inibição de proteases. Exemplos neste caso seriam o D-limoneno, 0 $\beta$-caroteno e os retinóides (WATTENBERG, 1985; 1990; DRAGSTED et al., 1993; MORSE e STONER, 1993).

\subsection{Carotenóides e $\beta$-Caroteno}

Após o isolamento do primeiro caroteno a partir da cenoura (Daucus carota), em 1831, descreve-se, atualmente, a existência na natureza de mais de 600 carotenóides cujas estruturas foram quimicamente caracterizadas, e isto para năo mencionar seus respectivos isômeros ópticos e geométricos (BRITTON, 1995; ARMSTRONG e HEARST, 1996).

Este tpo de compostos lipofilicos consfitui uma das classes mais abundantes e amplamente distribuidas de pigmentos naturais, sendo sintetizados por microrganismos fotossintéticos e plantas, mas não por animais, que dependem, portanto, inteiramente de fontes da alimentação (ARMSTRONG e HEARST, 1996; FURR e CLARK, 1997). Nesse caso, tais pigmentos presentes, por exemplo, na carne do salmão, carapaça da lagosta e plumagem do flamingo, são originários de fontes vegetais.

Desta forma, descreve-se, nesse sentido, que mais de 50 carotenóides são consumidos em quantidades apreciáveis na alimentação humana, tendo-se já detectado cerca de 34 no plasma e leite humanos, incluindo 13 isômeros geométricos e 8 metabólitos (KHACHIK et al., 1991; 1995; 1997).

Suas fontes vegetais comuns podem ser distribuidas em três grandes grupos (KHACHIK et al., 1991), a saber: no primeiro grupo, que inclui vegetais verdes tais como os brocolis, feijões verdes, espinafre e ervilha, estas apresentam uma ampla variedade de xantofilas e carotenos. Já o segundo, que inclui alimentos do tipo trutas e vegetais de cor amarela/vermelha, tais como o damasco, cenoura, cantalupe e tomates, ricos em carotenos, apresenta uma distribuição mais uniforme de carotenóides em suas fontes de origem vegetal do que o grupo anterior. Finalmente, o terceiro grupo inclui, por exemplo, a abóbora, laranja, ameixa e pêssego, ou seja vegetais também de cor amarela/vermelha, mas cujas fontes contêm xantofilas esterificadas com ácidos graxos, e que necessitam ser digeridas antes da absorção (WINGERATH et al., 1995).

A biossintese dos carotenóides se dá, inicialmente, a partir da condensação de duas moléculas de aceti-CoA para que estas formem acetoacetil-CoA, que por sua vez se condensa, novamente, com outra molécula de acetil-CoA, o que resulta em $\beta$-hidroxi-metil-glutaril-CoA, que através de uma etapa de redução, forma o mevalonato (BAUERNFEIND, 1972). Este, na presença de ATP é inicialmente convertido em fosfomevalonato, com subsequente fosforilação a pirofosfomevalonato, que após etapa de descarboxilaçăo com concomitante hidrólise de ATP, forma a importante unidade biológica isoprênica de 5 carbonos $\left(C_{5}\right)$, o pirofosfato de isopentenila (BAUERNFEIND, 1972; BASU e DICKERSON, 1996a).

Condensaçōes de quatro dessas uniđades isoprênicas $C_{5}$ dão origem a um intermediário com 20 átomos de carbono $\left(\mathrm{C}_{20}\right)$, o pirofosfato de geranilgeranila, que ao se condensar cauda-a-cauda com outua de suas moléculas, resulta no formação do primeiro carotenóide aciclico com 40 átomos de carbono, o fitoeno, que, por sua vez, serve de precursor clássico 
para outros carotenóides. Uma série de reaçōes de dessaturação e ciclizaçāo converte o fitoeno em carotenóides cíclicos, tais como o $\beta$-caroteno (BAUERNFEIND, 1972; BRITTON, 1995; ARMSTRONG e HEARST, 1996; BASU e DICKERSON, 1996a; FURR e CLARK, 1997).

Assim, a maioria dos carotenóides contém uma estrutura linear com 40 carbonos $\left(\mathrm{C}_{40}\right)$ incluindo 3 a 15 duplas ligações conjugadas que determinam, em grande parte, as propriedades espectrais de determinados destes compostos, que tipicamente absorvem luz entre 400 e $500 \mathrm{~nm}$ (ARMSTRONG e HEARST, 1996). Este esqueleto pode ser, entāo, modificado por ciclização em uma ou ambas as extremidades da molécula, por alterações no nivel de hidrogenação e por adição de grupamentos funcionais contendo oxigênio.

Carotenóides que apresentam apenas carbono e hidrogênio em suas moléculas são denominados de carotenos, e os que contêm uma ou mais funções de oxigênio são conhecidos como xantofilas. Já aqueles que apresentam estrutura com menos de 40 átomos de carbono, são denominados de apocarotenóides, se estes átomos foram perdidos a partir das extremidades das moléculas ou, então, de norcarotenóides, se perdidos a partir do interior das mesmas (BAUERNFEIND, 1972; BRITTON, 1995).

A característica mais tipica e proeminente da estrutura dos carotenóides e o longo sistema alternante de ligaçōes duplas e simples, que forma a parte central da molécula. Isto constitui um sistema conjugado no qual os $\pi$-elétrons são deslocados por todo o comprimento da cadeia poliênica. É justamente esta caracteristica que faz com que os carotenóides constituam um grupo distinto de substáncias com diferentes estruturas moleculares, reatividades químicas e propriedades de absorção de luz (KARNAUKHOV, 1990; BRITTTON, 1995).

Em princípio, cada dupla ligação da cadeia poliênica de um carotenóide pode existir em duas configurações, trans ou cis, dependendo da disposição dos grupamentos substutuintes. A maioria desses compostos ocorre, entretanto, originalmente na natureza na forma todo-trans, termodinamicamente mais estavel do que a forma cis. Todavia, devido ao elevado número de duplas ligaçōes os carotenóides podem sofrer isomerizaçăo de trans a cis, se expostos à luz em suas respectivas faixas de absorção. Esta interconversão pode ser ainda induzida através de energia térmica ou reações químicas (GERSTER, 1997a).

Além disso, todos os carotenóides com configuração todo-trans apresentam um sistema conjugado estendido de duplas ligações, consistindo em moléculas lineares e rigidas. Por oưo lado, os isômeros cis já não são mais simplesmente lineares e diferem substancialmente dos isômeros trans quanto à forma, de modo que suas capacidades de se adaptarem a estruturas subcelulares podem estar bastante alteradas. Assim, estes são mais solúveis e se encontram menos predispostos a sofrerem cristalização, o que possibilita, em principio, que sejam mais facilmente absorvidos e transportados do que suas contrapartidas todo-trans (BRITTON, 1995).

A forma e tamanho dos grupamentos terminais dos carotenóides constituem também importantes fatores. Assim, as moléculas de carotenobides aciclicos como o licopeno são longas e lineares, com grupamentos terminais flexiveis. Já a ciclização encurta o tamanho total da molécula e aumenta o volume efetivo dos grupamentos terminais e o espaço que ocupam (BRITTON, 1995).

Portanto, as características estruturais básicas dos carotenóides determinam as propriedades fisicoquímicas de suas moléculas e, consequentemente, respondem, em última instância, por suas funçães e açōes biológicas, incluindo, por exemplo, a absorção de energia luminosa e fotoproteçāo, importantes para a fotossintese, seus papéis como antioxidantes ou pro-oxidantes, bem como suas atividades como pró-vitamina A (BRITTON, 1995; OLSON e KRINSKY, 1995).

Descreve-se que para um carotenóide possuir atividade pró-vitamínica $A$, 0 composto deve apresentar ao menos um anel $\beta$-ionona (trimetil ciclohexano conjugado) não-substituido e 
uma cadeia lateral poliênica ligada. A outra extremidade da molécula pode variar quanto à estrutura ciclica ou aciclica e ser alongada, mas não encurtada a um fragmento poliênico contendo menos do que 11-carbonos (BAUERNFEIND, 1972; BASU e DICKERSON, 1996a).

Assim, o carotenóide $\beta$-caroteno possui dois anéis $\beta$-ionona, un em cada extremidade de uma longa cadeia poliênica com nove duplas ligaçōes, e apresenta, dentre os cerca de 50 carotenóides até o presente descritos como precursores da vitamina A, a maior atividade pro-vitaminica A (BAUERNFEIND, 1972; GOODMAN, 1984; OLSON e KRINSKY, 1995; BASU e DICKERSON, 1996a).

Nesse sentido, a primeira evidência conclusiva de que o $\beta$-caroteno atuava como uma pró-vitamina A na nutrição animal foi descrita em 1930 (MOORE, 1930), com a subsequente elucidação, ainda no mesmo ano, da estrutura do $\beta$-caroteno e outros carotenóides, bem como constatação da semelhança estrutural entre o $\beta$-caroteno e o retinol (vitamina A) ou retinaldeido (KARRER ef al., 1930).

Fontes importantes de $\beta$-caroteno incluem uma grande variedade de alimentos de origem vegetal, tais como as hortaliças folhudas verde-scuro, a cenoura, batata-doce, tomate, abóbora, manga, melāo, e o mamão (PENTEADO et al., 1986; KHACHIK et al., 1991; GODOY e RODRIGUES-AMAYA, 1994; MANGELS ot al., 1993; FURR e CLARK, 1997; THANE e REDDY, 1997). Em regiōes onde o bleo de dendê é utilizado, sua elevada concentração em $\beta$-caroteno representa importante fonte de vitamina $A$, como por exempio, no nordeste do Brasil e no oeste do continente africano (TRIGUEIRO e PENTEADO, 1992; BASU e DICKERSON, 1996a).

$O$ isômero 9-cis do $\beta$-caroteno, bem como outos isômeros cis desse carotenóide, são produzidos por certas espécies de algas verdes, e encontrados em alimentos, inclusive apos tratamento térmico (CHANDLER e SCHWARTZ, 1987; KHACHIK et al., 1989).

\subsubsection{Absorçăo, Transporte, Metabolismo e Armazenamento do $\beta$-Caroteno}

A absorção do $\beta$-caroteno, bem como dos outros carotenóides, envolve que estes sejam inicialmente liberados da matiz do alimento, onde se encontram associados com proteínas em uma série de estruturas da célula vegetal (ERDMAN et al., 1988; 1993).

Descreve-se que uma alteração fisica do alimento já antes da ingestão, como por exemplo através da cocção, é capaz de melhorar a liberação de carotenóides a partir da matriz, tais como o licopeno, e o $\alpha$ e $\beta$-caroteno (STAHL e SIEHS, 1992; POOR et al., 1993). Além disso, sugeriu-se que efeitos relacionados com a ligaçāo à matriz, seriam responsáveis, provavelmente, pela observação de que não houve melhora do estado nutricional relativo à vitamina $A$, de mulheres da Indonésia alimentadas com vegetais folhudos de cor verde, em comparação com mulheres que receberam biscoitos manufaturados de modo a conterem quantidade semelhante de $\beta$-caroteno em solução oleosa (DE PEE et al., 1995).

Após a ingestão, a hidrólise no estômago dos lípides e proteinas do alimentos libera os carotenóides đa matriz, que se dissolvem, entāo, na fina emulsão do conteúdo gástrico que passa, a seguir, ao duodeno. Nessa emulsão, a solubilidade e localização dos carotenóides diferem, tendendo os não-polares, ou seja, os carotenos, a permanecerem na região interna, e as xantofilas, carotenoides mais polares, distribuindo-se na superficie (BOREL et al., 1996).

Subsequentemente, ocorre transferência dos mesmos, da emulsāo para as micelas, onde os carotenóides tamberm adotam uma solubilização independente em diferentes regiões, de acordo com suas polaridades. Assim, descreve-se que o $\beta$-caroteno tende a se solubilizar no 
núcleo hidrofóbico da micela, enquanto o retinol, mais polar, é incorporado na superficie da partícula (EL-GORAB e UNDERWOOD, 1973; FURR e CLARK, 1997).

Esta serve como um reservatório de lípides e facilita suas travessias pela camada estacionária de água presente na superficie da membrana apical da bordadura em escova do enterócito, que absorve os carotenóides, incluindo o $\beta$-caroteno, de forma inalterada e por difusão passiva (HOLLANDER e RUBLE, 1978; MOORE et al., 1996; FURR e CLARK, 1997). É provável que a taxa de difusāo seja determinada pelo gradiente de concentração entre a micela e a membrana plasmática do enterócito (PARKER, 1996).

Altas concentraçōes de $\beta$-caroteno presentes no lúmen intestinal tendem a inibir sua própria difusão (PARKER, 1996). Observou-se ainda que a absorção de carotenóides depende de quantidades apropriadas de lipidios, proteínas e fibras presentes na alimentação, bem como de seu proprio conteúdo em carotenóides, que podem compefir, inclusive, uns com os outros (ROCK e SWENDSEID, 1992; BOWEN et al., 1993; WHITE ef al., 1993).

Assim que no interior do enterócito, 0 destino de um carotenóide depende de sua estrutura, sendo clivado enzimaticamente em vitamina $A$, como já foi anteriormente mencionado, se contiver um anel $\beta$-ionona não-substituido, associado a uma cadeia lateral poliènica com ao menos 11 átomos de carbono (BAUERNFEIND, 1972; BASU e DICKERSON, 1996a).

Em se tratanto do $\beta$-caroteno, seu mecanismo de clivagem é controverso, havendo sido sugeridas duas hipóteses, isto é, a da clivagem central ou excèntrica da molécula (OLSON, 1989a; WANG, 1994a; WOLF, 1995).

Nos anos de 1965 e 1983, demonstrou-se que esse carotenóide pode ser convertido em vitamina $A$ attavés da açāo da enzima $\beta$ - caroteno 15,15'-dioxigenase, presente no citossol dos enterócitos, no figado e no corpo lúteo (GOODMAN e HUANG, 1965; OLSON e HAYAISHI, 1965; SKLAN, 1983\}. Nesse caso, oxigênio molecular pode reagir inicialmente com os dois átomos centrais de carbono do $\beta$-caroteno, produzindo-se duas moléculas de retinaldeido que são subsequentemente reduzidas a retinol (vitamina A) pela enzima retinaldeido redutase, ou oxidadas à ácido refinóico. Isto foi confirmado em 1989, quando se observou a formação de retinol a partir do $\beta$-caroteno, em ensaio in vitro utilizando mucosa intestinal de coelhos ou ratos (LAKSHMAN et al., 1989).

A enzima $\beta$-caroteno 15,15'-dioxigenase tem a capacidade de clivar não apenas o $\beta$-caroteno todo-trans, mas também outros isômeros desse carotenóide. Relata-se que o isômero 9-cis do B-caroteno é também convertido em retinal, embora menos eficientemente do que a forma todotrans (NAGAO e OLSON, 1994). Acredita-se ainda que outros carotenóides com atividade próvitamínica A sejam também convertidos pela enzima, apesar de sua especificidade não estar ainda bem estabelecida (NAN VLIET, 1996).

Já a ocorrência da clivagem excêntrica do $\beta$-caroteno foi detectada pela primeira vez em plantas e microrganismos (GLOVER, 1960) e, a seguir, no intestino de ratos, galináceos, "ferrets" (Mustela putoris turo), MACacos e seres humanos (SHARMA et al, 1977; GANGULY e SASTRY, 1985; TANG et al., 1991; WANG et al., 1991). A reação dá origem a diferentes cadeias de 12'-, 10'- e 8'- $\beta$-apo-carotenais, que podem ser, então, convertidos em retinaldeldo ou oxidados em ácidos $\beta$-apo-carotenóicos. Estes últimos são também possiveis precursores do ácido retinóico (NAPOLI e RACE, 1988). Além disso, alguns dos apocarotenais sāo relativamente polares, podendo ser transportados do intestino ao figado através do sistema porta (FURR E CLARK, 1997).

Não existe até o momento, entretanto, consenso na literatura quanto à importância relativa da clivagem central ou excêntrica do $\beta$-caroteno para a formação de retinóides, apesar de se ter conhecimento da ocorrência de ambas (HANSEN e MARET, 1988; WANG, 1994). 
Todavia, descreve-se que a produção de ácido retinóico a partir do $\beta$-caroteno pode ocorrer preferencialmente através da clivagem excêntrica da molécula do carotenóide, pois esta via resulta em $\beta$-apo-carotenais que podem dar origem diretamente ao ácido retinóico, ao invés de retinaldeído (WANG, 1994).

Assim, a produção de ácido retinóico a partir de $\beta$-caroteno pode ocorrer no "ferret", rato, Macaco e ser humano, tanto no intestino delgado como em tecidos periféricos, tais como 0 pulmão, rim, figado e tecido adiposo (NAPOLI e RACE, 1988; WANG et al., 1991). Sugere-se que este ácido refinóico produzido a partir do metabolismo do $\beta$-caroteno, teria um efeito regulatório no metabolismo da vitamina $A$, via retroalimentação inibitória da oxidaçāo do refinol e estimulação de sua esterificação (WANG et al., 1993; WANG, 1994).

A razão de conversão do $\beta$-caroteno em vitamina $A$ no organismo, que usualmente é de 6:1 em seres humanos (BAUERNFEIND, 1972; BRUBACHER e WEISER, 1985), depende de fatores como por exemplo da atividade tireoidiana, da presença ou ausência de estresse, presença de interferentes nos alimentos, tais como concentrações elevadas ou reduzidas de nitratos, proteinas ou lipideos, e, principalmente, das próprias concentrações do carotenóide nos alimentos (SOLOMONS e BULUX, 1993).

Doses elevadas de $\beta$-caroteno resultam em importante redução na eficiência de conversão (BAUERNFEIND, 1972; BRUBACHER e WEISER, 1985). relata-se ainda que a absorção e a extensão da clivagem intestinal do $\beta$-caroteno em vitamina $A$ dependem, ao menos no rato, da concentração da vitamina A na raçāo (NAN VLIET et al., 1996).

Portanto, o grau de conversão de $\beta$-caroteno em vitamina A é regulado por mecanismos homeostáticos, dependendo, por exemplo, da quantidade de vitamina A pré-formada na alimentação e da saturação dos depósitos de vitamina A do organismo (GERSTER, 1991). Estes mecanismos limitariam a conversão do carotenóide, no sentido de uma proteção contra eventual toxicidade pela vitamina $A$

Descreve-se, ainda, que a razāo de conversão de outros carotenóides com atividade próvitaminica $A$ em retinol é de aproximadamente a metade daquela do $\beta$-caroteno (KRINSKY, 1989b). Além disso, estudos conduzidos ente 1944 e 1952 demonstraram que estereoisômeros cis-trans do $\beta$-caroteno também apresentam menor taxa de conversão em vitamina $A$ do que 0 isômero todo-trans (DEUEL et al., 1944; ZECHMEISTER et al., 1952).

Na espécie humana, a maior parte do $\beta$-caroteno absorvido é convertida nos enterócitos em retinol e, a seguir, em ésteres de retinila (NAN VLIET, 1996). Entretanto, descreve-se que aproximadamente $15 \%$ desse carotenóide na sua forma intacta, podem ser encontrados no sistema linfático (GOODMAN et al., 1966).

Observou-se ainda que $20-40 \%$ do $\beta$-caroteno presente em tecidos humanos se encontram na forma de isômeros cis, ao mesmo tempo em que não se conseguiu demonstrar suas presenças no plasma (STAHL et al., 1992), nem mesmo após suplementação com uma preparação de $\beta$-caroteno contenđo $60 \%$ na forma de isômero cis (JENSEN et al, 1987). Isto poderia indicar, portanto, que os isômeros cis do $\beta$-caroteno são depurados preferencialmente do plasma (VAN VLIET, 1996).

Desta forma, os seres humanos podem acumular a molécula integra do $\beta$-caroteno no sangue e tecidos, o mesmo se observando em outros mamíferos tais como o cavalo e o "ferret" (BONDI e SKLAN, 1984).

Em outros animais, como o rato, coelho, porco e galináceos, descreve-se, entretanto, que grandes quantidades do carotenóide presente na alimentação săo convertidas em vitamina $A$ (HUANG e GOODMAN, 1965; WANG, 1994; PARKER, 1996), não estando, portanto, o rato 
indicado como modelo in vivo para o estudo do metabolismo do $\beta$-caroteno (BENDICH e OLSON, 1989; RIBAYA-MERCADO ef al, 1989; WANG, 1994).

Todavia, vários estudos têm demonstrado, inclusive mais recentemente, que essa espécie pode acumular grandes quantidades do carotenóide intacto, especialmente no figado, quando este é aưicionado à ração ou administrado por sonda gástrica (MATHEWS-ROTH, 1977; SHAPIRO et al,, 1984; KRINSKY et al., 1990; MORENO et al., 1991; OKOH et al., 1993; BIANCHI-SANTAMARIA et al., 1994; SARKAR ef al, 1994; MORENO ef al, 1995a; TEE et al., 1996; RIZZl et al., 1997).

Em contraste com o retinol, não se relatou a existência no enterócito de proteína intracelular capaz de se ligar a carotenóides, talvez devido à presença de grande número desses compostos na alimentação (PARKER, 1996). Entretanto, demonstrou-se a existência de um complexo proteina-carotenóide no figado de ratos alimentados com rações contendo $\beta$-caroteno, possivelmente envolvido com o armazenamento e transporte da molécula intacta desse carotenóide (OKOH et al, 1993).

Recentemente descreveu-se também a purificaçāo e caracterizaçāo parcial de uma proteina celular ligadora de $\beta$-caroteno com 67 kDa no figado de "ferrets", capaz ainda de se ligar ao $\alpha$-caroteno e à criptoxantina, mas não a outros carotenóides testados, o que sugere um elevado grau de especificidade de ligação apenas a carotenóides com ao menos um anel $\beta$-ionona não-substituido (RAO et al., 1997). Esta proteina poderia desempenhar um papel importante no armazenamento, tansporte, direcionamento e proteção do $\beta$-caroteno contra a degradação.

Os carotenóides que nāo sofreram clivagem no enterócito sāo, então, incorporados em quilomícrons e transferidos por exocitose ao sistema linfático e, a seguir, para a circulação sistêmica. Em células periféricas essas lipoproteinas resultam na formação, após hidrólise de parte de seus triacilglicerois pela lipase de lipoproteina, dos assim chamados remanescentes de quilomícrons, que são, subsequentemente, captados por hepatócitos que apresentam receptores BIE em suas superficies (MAHLEY e HUSSAIN, 1991).

No figado, os carotenóides ainda presentes nesses remanescentes de quilomicrons podem ser convertidos em refinóides ou incorporados em lipoproteinas de densidade muito baixa (VLDL), sendo a seguir, novamente transportados às células periféricas e transferidos para as lipoproteinas de baixa densidade (LDL) (BLOMHOFF, 1994; VAN VLIET, 1996). Assim, descreve-se que principalmente a LDL (CLEVIDENCE e BIERI, 1993; TRABER et al., 1994), mas também a lipoproteina de alta densidade (HDL) (PARKER, 1996), representam, na verdade, os principais meios de transporte de $\beta$-caroteno no plasma.

Relata-se, ainda, que o figado é o principal síbo de acúmulo de $\beta$-caroteno no organismo, quando rações suplementadas com esse carotenóide foram administradas a espécies tais como ratos e galináceos (LEVIN et al, 1994), ou quando o $\beta$-caroteno foi adicionado à água fornecida a camundongos (IYAMA et al., 1996). Nesse sentido, quanto à localização subcelular, demonstrou-se que esse carotenóide está principalmente presente na fração mitocondrial $e$, a seguir, nos lisossomos de fígado de animais dessas espécies (MAYNE e PARKER, 1986; OKOH et al., 1993).

Já em seres humanos, o $\beta$-caroteno foi detectado nas adrenais, figado, testiculos, tecido adiposo, pele, rins e pulmões (RAICA et al., 1972; MATHEWS-ROTH, 1991; SCHMTZ et al., 1991; FURR e CLARK, 1997).

De uma forma geral, a dinâmica da absorção, transporte no plasma, depuração e metabolismo é altamente dependente da natureza quimica do carotenóide (ZENG et al., 1992). Assim, relata-se a existência de capacidade de discriminaçāo em relação à absorção, ou até 
mesmo em relação ao transporte, dos isômeros todo-trans e 9-cis do $\beta$-caroteno, em favor do primeiro (GAZIANO et al., 1995; STAHL ef al., 1995).

Descreve-se também que os isômeros todo-trans e 9-cis desse carotenóide, que podem ainda sofrer interconversão, são rapidamente metabolizados mas que o primeiro resulta apenas em produtos todo-trans, enquanto o $\beta$-caroteno 9-cis dá origem a uma mistura de produtos todo-trans e 9-cis (NAGAO e OLSON, 1994; WANG et al., 1994).

Observa-se, ainda, em seres humanos, a ocorrência, durante ou após a absorção, de isomerizaçāo para a forma 9-cis após ingestāo de $\beta$-caroteno todo-trans (TAMAl et al., 1995), bem como de isomerização cis-trans do $\beta$-caroteno 9 -cis, durante sua absorção e antes da secreção para a corrente sanguínea (YOU et al., 1996). Neste último caso, sugere-se que isto limitaria o fornecimento de retinóides 9 -cis aos tecidos, aumentando ainda o valor em vitarnina $A$ do carotenóide.

Assim, estudos in vitro ưdilizando homogenatos de intestino ou figado demonstram a ocorrência de síntese de retinaldeido 9-cís e ácido retinóico 9-cis, após incubaçāo com B-caroteno 9-cis (NAGAO e OLSON, 1994; WANG et al, 1994). Além disso, relatou-se em "ferrets", a ocorrência de sintese in vivo de ácido retinóico 9-cis a partir do isômero 9-cis do $\beta$-caroteno (HEBUTERNE et al., 1995).

A presença de precursores e a biossíntese de ácido retinóico 9-cis têm grande importância biológica, devido ao fato de que este pode agir como ligante para receptores nucleares capazes de modularem a expressāo gênica (MANGELSDORF, 1994; NAGAO e OLSON, 1994; PARKER, 1996).

\subsubsection{Propriedades Biológicas do $\beta$-Caroteno}

Devido ao grande número de propriedades já atribuídas aos carotenóides, sugeriu-se que estas poderiam ser distribuidas em tês categorias, ou seja, funçōes, açōes ou associaçōes, úteis para se classificar as várias relações entre carotenóides e processos fisiológicos ou biológicos (BENDICH e OLSON, 1989; OLSON, 1989b; KRINSKY, 1994).

Funções podem ser definidas como os papéis essenciais que estes desempenham, ao menos sob certas condições determinadas. Portanto, a ausência do carotenóide resulta, neste caso, em incapacidade fisiológica e, eventualmente, até em morte. Já açōes podem ser consideradas respostas fisiológicas ou farMACológicas à administraçāo de carotenóides. Entretanto, a resposta, que pode ser benéfica ou deletéría, não é essencial ao bem estar fisiológico. Finalmente, as associações definem correlaçōes entre carotenóides e algum evento fisiológico ou biológico que possa, ou não, apresentar efetivamente uma relação causal (BENDICHe OLSON, 1989).

Em algumas instâncias, entretanto, as diferenças estabelecidas entre ações e associações não sāo claras, podendo-se combinà-las em um único grupo (KRINSKY, 1994).

Em se tratando do $\beta$-caroteno, sua funçāo de conversão em vitamina A é bastante conhecida, bem como sua capacidade de fotoproteção, inclusive na protoporfiria eritropoiética e outras doenças fotossensiveis. Por outro lado, descreve-se que suas ações e associações mais importantes consistiriam, basicamente, em efeitos nas atividades de diversas enzimas, atividade antioxidante/pró-oxidante, capacidade de modular a expressāo gênica e a resposta imune, e de, eventualmente, ter influência na reprodução e fertilidade, bem como em diversas doenças degenerativas tais como a catarata, degeneração Macular relacionada com a idade, aterosclerose e o câncer (BENDICH e OLSON, 1989; ROSS e TERNUS, 1993; KRINSKY, 1994; 
MEYDANI et al., 1995; OLSON e KRINSKY, 1995; OLSON, 1996; BURRI, 1997; SILVEIRA e MORENO, 1998).

\subsection{3 $\beta$-Caroteno e Câncer}

\subsubsection{Estudos em Humanos}

Desde a publicaçāo da extensa revisão de PETO et al. (1981), que incluiu oito estudos retrospectivos de diversos paises e uma região em que as concentrações séricas de retinol de pacientes portadores de câncer recém diagnosticado eram significantemente menores do que as do grupo controle, e da consequente hipótese de que o $\beta$-caroteno poderia reduzir a incidència de câncer, têm se acumulado evidências obtidas a partir de inúmeros estudos epidemiolćgicas, retrospectivos e prospectivos, de que individuos que ingerem maiores quantidades de frutas e hortaliças ricas em carotenóides, ou com concentraçōes sanguineas mais elevadas de $\beta$-caroteno, apresentam menor risco de desenvolvimento de cánceres em diversos órgãos, especialmente no pulmão e estómago (ZIEGLER, 1991; BLOCK et al, 1992; VAN POPPEL e GOLDBOHM, 1995; MAYNE, 1996; ZIEGLER et al., 1996a; NAVES e MORENO, 1998).

Entretanto, nesse interim, não se conseguiu estabelecer de forma conclusiva relação exclusiva entre a ingestāo de $\beta$-caroteno e o câncer através dos dados epidemiológicos observacionais disponiveis, pois a maioria das investigaçōes não analisou especificamente o consumo do carotenóide e nem explorou, adequadamente, a influência relativa de fatores interferentes presentes na alimentação, como por exemplo, a presença concomitante de outros carotenóides ou componentes tais como minerais, fibras e outros fitoquímicos, bem como do colesterol, carne ou bebidas alcoólicas (MAYNE, 1996; NAVES e MORENO; 1998).

Além disso, descreve-se que a concentraçāo de $\beta$-caroteno no sangue poderia também apenas refletir o consumo de frutas e hortaliças, e ser afetada por variáveis não adequadamente controladas na maioria dos estudos, como por exemplo, o tabagismo (ZIEGLER ef al., 1992; KOO, 1997).

Todavia, este tipo de investigação possibilitou que se concluisse que o $\beta$-caroteno, se protetor, seria mais efetivo quando ingerido em quantidades fisiológicas normalmente encontradas em uma alimentação rica em frutas e hortaliças, ou seja, cerca de 4 a $6 \mathrm{mg} /$ dia (SHEKELLE et al., 1981; ZLEGLER of al., 1992, 1996b), e que teria principalmente ação nas etapas iniciais da carcinogênese (STÄHELIN ef al., 1991; VAN POPPEL e GOLDBOHM, 1995).

Assim, a consistência dos resultados dos estudos epidemiológicos observacionais em relação aos carotenóides e a prevenção do câncer de pulmāo, bem como os dados então disponiveis relativos à ausência de toxidade do $\beta$-caroteno (BENDICH, 1988) e sua eficácia na quimioprevenção em modelos de carcinogênese experimental (MATHEWS-ROTH, 1985), serviu de estímulo ao desenvolvimento de estudos em grande escala em seres humanos, com suplementação farMACológica crônica do carotenóide, isoladamente ou em combinação com outros nutrientes.

Desta forma, no Tyler Chemoprevention Trial administrou-se $\beta$-caroteno ( $50 \mathrm{mg} / \mathrm{dia}$ ) e retinol (25.000 UI em dias alternados) a individuos expostos ao asbesto por motivos profissionais, na tentativa de se avaliar se esta combinação poderia reduzir a prevalência de células atípicas no escarto (MCLARTY ef al., 1995). Ao contrário do que se esperava, após um 
periodo de intervenção de 58 meses observou-se nos indiviơos que receberam os suplementos, aumento não-significante de atipia no escarro.

Já se havia descrito, por outro lado, em um estudo aleatório de intervençāo conduzido anteriormente por 14 semanas, que a suplementação com $\beta$-caroteno (20 mg/dia) reduzu significantemente a contagem de micronúcleos no catarro de fumantes inveterados (VAN POPPEL et al., 1992).

Três investigaçōes publicadas mais recentemente não detectaram, entretanto, qualquer efeito protetor na incidência de diversos cânceres, quando o $\beta$-caroteno foi administrado isoladamente ou em combinação com a vitamina $A$, a milhares de individuos (THE ALPHA TOCOPHEROL, BETA-CAROTENE CANCER PREVENTION STUDY GROUP, 1994; HENNEKENS ef al, 1996; OMENN ef al., 1996).

Duas destas chegaram a demonstrar, inclusive, que o carotenóide poderia ter um efeito deletério, aumentando a incidência de câncer pulmonar (THE ALPHA TOCOPHEROL, BETACAROTENE CANCER PREVENTION STUDY GROUP, 1994; OMENN et al., 1996).

Como estas investigaçōes foram conduzidas em populaçōes consideradas "de alto risco" para o desenvolvimento de câncer de pulmão (fumantes inveterados, ex-fumantes ou individuos expostos ao asbesto), e como os suplementos em doses farmacológicas crònicas foram administrados em uma fase em que já era possivel que a carcinogênese pulmonar se encontrasse em suas etapas mais tardias, sugeriu-se que seus resultados negativos não deveriam ser generalizados para toda a população. Não se deveria descartar ainda definitivamente um possivel papel do $\beta$-caroteno na prevenção do câncer, especialmente se este fosse administrado nas fases iniciais da carcinogênese e em quantidades mais fisiológicas, associado a substâncias antioxidantes, como as naturalmente encontradas em uma alimentação rica em frutas e hortaliças (GRADELET et al., 1998; NAVES e MORENO, 1998).

Assim, descreveu-se que o $\beta$-caroteno demonstrou efeitos quimioprotetores contra os cânceres de esôfago e cárdia, quando administrado em concentrações menores do que as utilizadas na majoria dos outros estudos e concomitantemente à vitamina $E$ e selênio, a milhares de individuos de populaçōes de Linxian, na China, e que apresentavam consumo reduzido de nutrientes e concentrações plasmáticas reduzidas do carotenóide (BLOT ef al., 1993).

Relatou-se, ainda, que em seres humanos a suplementação com $\beta$-caroteno se mostrou eficaz na reversão da leucoplaquia, considerada uma lesāo pré-neoplásica do câncer da cavidade oral. Este efeito protetor foi inicialmente constatado em investigação realizada na Índia em mascadores de fumo ou de noz de areca (STICH et al., 1988a).

A seguir, diversos estudos demonstraram reversão ou supressão de 50 a $60 \%$ dos casos de leucoplaquia, em individuos tratados com cerca de 30 a $60 \mathrm{mg} /$ dia de $\beta$-caroteno, por aproximadamente seis meses (GAREWAL, 1995). Mais recentemente, descreveu-se ainda redução significante no número e grau de displasia da mucosa oral, em 97,5\% dos casos tratados com o carotenóide associado ás vitaminas E e $C$, por periodo de 12 semanas consecutivas (BARTH et al., 1997).

Resultados promissores foram também relatados em mulheres portadoras de displasias de colo uterino, que receberam suplementos de $\beta$-caroteno ( $30 \mathrm{mg} / \mathrm{dia}$ ) por via oral durante 6 meses consecutivos (MEYSKENS JR. e MANEITA, 1995). 


\subsubsection{Estudos in vitro e em Animais de Experimentaçăo}

Em 1973, DGROGOKUPLA e colaboradores, apud MATHEWS-ROTH (1989), induziram cânceres subcutâneos e de pele em camundongos e ratos, através da administração de 9,10-dimetil-1,2-benz(a)antraceno (DMBA), observando que aqueles animais tratados com uma ração suplementada com "quantidades ilimitadas de cenoura" desenvolviam neoplasias mais lentamente do que aqueles alimentados com raçōes nāo-suplementadas, e propondo que o efeito do $\beta$-caroteno poderia ser devido, neste caso, à sua transformação em vitamina A.

Nesse mesmo ano EPSTEIN (1973) descreveu que camundongos "hairtess" expostos à radiação ultravioleta do tipo $B$ (UV-B), e que recebiam injeções de $\beta$-caroteno, desenvolviam cânceres de pele a uma menor velocidade do que camundongos que apenas recebiam injeçöes de placebo.

A seguir, SEIFTER e colaboradores (1981; 1982; RETTURA et al., 1982), em uma série de experimentos conduzidos em camundongos, relataram que a vitamina $A$ e o $\beta$-caroteno eram capazes de inibir o desenvolvimento e reduzir as dimensōes de neoplasias malignas transplantadas ou induzidas por vírus.

Posteriormente, MATHEWS-ROTH (1982; 1983) observou que as administaçōes de cantaxantina e fitoeno, um carotenóide sem atividade pró-vitaminica $A$ e um derivado isoprênico, respectivamente, bem como de $\beta$-caroteno, protegiam camundongos "hairless" contra cânceres cutâneos induzidos por radiação UV-B ou aplicação de DMBA como agentes iniciantes, seguida da aplicação de óleo de cróton como agente promotor, retardando seus aparecimentos e reduzindo seus números por animal.

Outras investigaçōes utilizando modelos experimentais semelhantes tiveram oportunidade de confimar os resultados desses experimentos, em que os carotenóides foram administrados por via oral, antes ou durante a formaçāo das neoplasias, ou seja, nas fases de iniciaçāo ou promoção da carcinogênese (SANTAMARIA et al., 1983; SEIFTER et al., 1984; MATHEWSROTH e KRINSKY, 1985).

Nesse sentido, desmonstrou-se ainda, posteriormente, que o $\beta$-caroteno era também capaz de inibir a carcinogênese de pele UV-induzida em camundongos, quando o tratamento com o carotenóide foi iniciado após término da aplicaçāo da irradiação UV-B, ou seja, durante a fase de progressão da carcinogênese (MATHEWS-ROTH e KRINSKY, 1987).

Anteriormente, entretanto, SHAMBERGER (1971) já havia descrito que a aplicação tópica de $\beta$-caroteno era capaz de aumentar a formação de neoplasias cutâneas, em camundongos submetidos a modelo experimental de carcinogênese induzida pelo DMBA e óleo de cróton.

Em contraste, em uma observação já mais recente, relatou-se que o $\beta$-caroteno apresentou um efeito protetor quando administado topicamente tanto durante a fase de iniciação como de promoção de modelo de carcinogênese oral em "hamsters", induzida pela aplicaçāo tópica de DMBA como agente iniciante e de peróxido de benzoila como agente promotor (SUDA et al, 1986). Atribuiu-se, nesse caso, a açāo protetora do carotenóide a uma indução de um fator de necrose tumoral em macrófagos (SCHWARTZ et al., 1986).

Descreveu-se ainda posteriormente nesse modelo de carcinogênese oral em "hamsters", uma reduçāo significante no número de neoplasias por animal, quando o $\beta$-caroteno foi administrado por via oral (ALAM e ALAM, 1987; SCHWARTZ ot al., 1988).

Analisando parte dessas observaçōes, MATHEWS-ROTH (1989) concluiu que as mesmas sugeriam, de uma forma geral, que a atividade protetora do $\beta$-caroteno poderia ser 
diretamente atribuida à própria molécula do carotenóide, através de sua capacidade de sequestrar radicais livres, ou seja, sua ação antioxidante, e não à sua função de atuar indiretamente no organismo como pró-vitarnina $A$.

Nesse sentido, SOM e colaboradores (1984), procurando ainda avaiiidr de forma mais especifica a ação quimiopreventiva do $\beta$-caroteno na carcinogênese, observaram que este carotenóide era capaz de inibir a transformaçăo in vitro de glândulas mamárias induzida pelo DMBA, concluindo que este efeito ocorria tanto na fase de iniciação como de promoção, pois podia ser observado quando o $\beta$-caroteno era adicionado à cultura concomitantemente ao DMBA ou 4-10 dias após. Sugeriu-se também neste caso que este efeito inibitório poderia ser atribuido, provavelmente, a uma ação direta do $\beta$-caroteno, talvez relacionada à capacidade do carotenóide de reduzir a troca de cromátides irmãs, pois não havia acúmulo detectável de retinol nas glândulas durante 10 dias de cultura de tecido.

Por outro lado, experimentos realizados com células $\mathrm{C} 3 \mathrm{H} 10 \mathrm{~T} 1 / 2$ em que se adicionava $\beta$-caroteno ou cantaxantina à cultura, demonstraram que estes compostos reduziram a extensão da transformação maligna induzida por metilcolantreno ou raios $X$, quando administrados 1 semana após o tratamento, ou seja, na fase de promoção (PUNG et al,, 1988). Como não se detecłava conversão do ${ }^{14} \mathrm{C}-\beta$-caroteno em ${ }^{14} \mathrm{C}$-retinóides, sugeriu-se que 0 carotenóide deveria estar atuando de forma intrínseca nessas condições experimentais, e não como pró-vitamina A (RUNDHAUG et al, 1988).

A atividade protetora in vivo do $\beta$-caroteno, que parece ocorter especialmente em casos de neoplasias de origem epitelial (GERSTER, 1993), foi também observada em diversos outos modelos experimentais de carcinogênese.

Assim, relatou-se ainda uma redução na incidência de câncer de cólon em camundongos alimentados com raçỏes suplementadas com o carotenóide e submetidos à administraçăo de dimetilhidrazina (DMH) (TEMPLE e BASU, 1987).

Além disso, descreveu-se que a administração de raçōes suplementadas com $\beta$-caroteno a camundongos Skh tratados com DMBA como agente iniciante da carcinogênese e um éster de forbol como promotor, teve um efeito protetor ao reduzir em $32 \%$ o aparecimento de neoplasias de pele (LAMBERT et al., 1994).

Da mesma forma, camundongos CD-1 submetidos à aplicação tópica de DMBA por 60 dias e subsequentemente tratados durante 14 dias consecutivos com $\beta$-caroteno dissolvido em óleo de amendoim e por intubação gástrica, apresentaram redução significante no tamanho de papilomas cutâneos, quando comparados a animais do grupo controle (KATSUMURA et al., 1996). Sugeriu-se, neste último caso, que a ação anticarcinogênica in vivo do carotenóide poderia ser atribuida a uma atividade intrinseca da molécula do $\beta$-caroteno, e não à sua função como pró-vitamina A.

Os resultados destes estudos estavam de acordo com experimento realizado anteriormente em camundongos SENCAR submetidos a modelo semelhante de carcinogénese de pele induzida pelo DMBA, em que se observou que o carotenóide suplementado na raçāo foi capaz de inibir a conversăo de papilomas a carcinomas cutâneos (CHEN et al., 1993).

Demonstrou-se, ainda, que a administração de $\beta$-caroteno na ração durante as fases de iniciação e pós-iniciaçăo da carcinogênese oral induzida pelo agente iniciador 1-óxido de 4-nitroquinolina, resultou em significante redução na frequência de aparecimento de carcinomas de lingua em ratos F-344 (TANAKA et al., 1994) e que o carotenóide, quando administrado simultaneamente a rações contendo elevados teores de gordura durante a fase de promoçāo de modelo de carcinogênese pancreática, foi tambem capaz de inibir em ratos a formação de focos basofilicos no pâncreas desencadeada pela aplicação de azasserina, enquanto 
em "hamsters" resultou em reduçōes significantes no aparecimento de complexos ductais iniciais e no numero de carcinomas, após administração de $\mathrm{N}$-nitosobis(2-oxopropil)amina (WOUTERSEN e VAN GARDEREN-HOETMER, 1988).

Estas observaçōes foram confirmadas mais recentemente. Assim, demonstrou-se também uma ação inibitória do $\beta$-caroteno quando adicionado à ração em uma suspensão de óleo de milho a $30 \%$, em ratos tratados com azasserina como indutor da carcinogênese pancreática, constatando-se que esse efeito protetor foi mais pronunciado quando o carotenóide foi administrado durante a fase de promoção tardia do processo carcinogênico (APPEL e WOUTERSEN, 1996). Além disso, descreveu-se que o $\beta$-caroteno suplementado nas raçōes também apresentou efeitos inibitórios reduzindo o número de lesões pré-neoplásicas ductais, bem como o de carcinomas in situ e invasivos, na carcinogênese pancreática iniciada em "hamsters" pelo carcinogênico $\mathrm{N}$-nitrosobis(2-oxopropil)amina (MAJIMA et al., 1998).

O potencial quimiopreventivo do carotenóide quando suplementado nas rações ou administrado por via subcutânea, foi ainda recentemente avaliado em modelo de carcinogénese pulmonar induzida em camundongos pelo carcinógeno tabaco-especifico, 4(metilnitrosamino)1-(3-piridil)-1-butanona, observando-se que não houve inibição na formação do número total de neoplasias, que incluiam adenomas e adenocarcinomas, embora o $\beta$-caroteno reduzisse significantemente a incidência de adenocarcinomas, ou seja, retard́asse a progressão maligna (CONAWAY et al., 1998).

Entretanto, nem todos os estudos com o $\beta$-caroteno foram capazes de demonstrar, in vivo, uma açāo protetora na carcinogênese experimental. Assim, nāo se constałou em "hamsters" alimentados com rações contendo o carotenóide e submetidos à instilação intratraqueal de benzo( $\alpha$ )pireno ligado a óxido férrico, efeito protetor significante quando se levou em conta o número ou tipo de neoplasias do tato respiratório (BEEMS, 1987). Todavia, sugeriu-se que esta observação especifica é questionável, pois o tratamento com $\beta$ caroteno nảo resultou, nessas condiçōes experimentais, e como era de se esperar, em alterações significantes nos niveis séricos de refinol (KRINSKY, 1991).

Não se constataram efeitos significantes na prevenção de cânceres colorretais, em ratos administrados com DMH e alimentados com raçōes suplementadas com o carotenóide na forma de grânulos ("beadlets") (COLACCHIO e MEMOLI, 1986). Quando adicionada à ração, esta apresentação granular do $\beta$-caroteno também nāo resultou em atividade protetora digna de nota em modelos de carcinogênese de estômago e intestino delgado, bem como colorretal, em ratos tratados com N'-metil- $N$-nitro- $N$-nitrosoguanidina (MNNG) adicionada à agua dos bebedouros por 52 semanas consecurfivas, ou por instilação intrarretal, apesar de se ter observado nesse estudo, leve reduçāo na incidència de adenocarcinomas gástricos (JONES et al., 1989).

Todavia, descreveu-se em um experimento mais prolongado que este último, e conduzido durante 550 dias, que o carotenóide foi capaz de prevenir o câncer gástrico induzido em ratos pela administração oral de MNNG (SANTAMARIA et al., 1987).

\subsubsection{1 $\beta$-Caroteno e Hepatocarcinogênese Experimental}

A ação quimiopreventiva do $\beta$-caroteno foi também avaliada em modelos de hepatocarcinogênese. Assim, RIEDER e colaboradores (1983), apud ASTORG et al. (1996), observaram, pela primeira vez, que rações suplementadas com cenouras eram capazes de 
retardar em ratos o aparecimento de hepatomas induzidos pela aplicação de DEN, embora não houvessem evidências de que este efeito pudesse ser atribuido diretamente ao $\beta$-caroteno.

Mais recentemente constatou-se, entretanto, e de uma forma mais controlada, ação inibitória do carotenóide no desenvolvimento de lesões pré-neoplásicas (focos e nódulos de hepatócitos) de ratos Wistar submetidos ao modelo do hepatócito resistente (RH), quando este foi administrado por intubação gástrica dissolvido em bleo de milho, principalmente durante periodo que abrangia as fases de iniciaçāo e seleção/promoção concomitantemente ou apenas a etapa da iniciação, mas também quando aplicado tão somente durante a fase de promoçāo precoce da hepatocarcinogênese (MORENO et al., 1991; 1995a; RIZZI et al, 1997; DAGLl et al., 1998; OLIVEIRA, 1998; FIORIO, 1998).

Demonstrou-se, ainda, nessas condiçōes experimentais, que a administração de $\beta$-caroteno resultou em aumento das concentraçoes hepáticas do carotenoide, bem como da vitamina A total (MORENO et al., 1991; 1995a; RIZZ et al, 1997; OLIVEIRA, 1998). Por outro lado, ratos tratados com vitamina $A$ e submetidos ao modelo do hepatócito resistente, além de não apresentarem efeitos inibitónios dignos de nota durante as fases iniciais da hepatocarcinogênese, também não demonstraram, como era de se esperar, aumento das concentrações hepáticas de $\beta$-caroteno, embora apresentassem concomitantemente aumento acentuado das concentraçōes hepáticas de vitamina A total.

Estas evidências possibilitaram, portanto, que se chegasse à conclusão de que o efeito quimiopreventivo do carotenoide poderia ser atribuido, nesses casos, a uma ação intrínseca do $\beta$-caroteno inerente à sua própria molécula e não à sua função como próvitamina A (MORENO et al., 1995a; RIZ7l ot al., 1997).

$O$ efeito inibitório do $\beta$-caroteno na hepatocarcinogènese foi também posteriormente observado em outros estudos, empregando, inclusive, diferentes modelos experimentais e outras linhagens de ratos, bern como outros animais.

Assim, confirmando os resultados dos experimentos descritos anteriormente, descreveu-se que a administração de raçōes suplementadas com o carotenóide a ratos da linhagem Sprague-Dawley era capaz de inibir a hepatocarcinogênese induzida pelos carcinogenos 2-acetilaminofluoreno (2-AAF) (SARKAR et al., 1994), DEN (SARKAR et al., 1995a) ou 3'-metil-4-dimetilaminoazobenzeno (3'-MDAB) (SARKAR et al., 1995b), quando ocorria também principalmente durante periodo que abrangia as etapas de iniciaçăo e seleção/promoção concomitantemente, ou apenas a etapa de iniciação.

Relatou-se ainda que o $\beta$-caroteno suplementado nas rações foi capaz de exercer efeitos inibitórios em lesōes pré-neoplásicas (focos de hepatocitos) presentes durante a etapa de iniciação da hepatocarcinogênese, induzida em ratos por modelo experimental que empregava como processo de iniciação, dose única intragástrica do carcinogênico de alimentos 2-amino-3-metilimidazo[4,5-f]quinolina (IQ) aplicada 12 horas após realização de hepatectomia parcial a dois terços, seguidas por administração de fenobarbital e dose única de D-galactosamina como regime promotor (TSUDA et al., 1994).

Da mesma forma, observou-se que a administração a ratos Fischer 344, por intubação gástrica, de extratos de alimentos ricos em carotenóides como o $\beta$-caroteno (cenouras), inibiu o desenvolvimento de lesões pré-neoplásicas (focos de hepatócitos) presentes nas fases iniciais da hepatocarcinogênese induzida pela aplicação de aflatoxina Bł (HE et al., 1997).

Além disso, em modelo de hepatocarcinogênese experimental induzida pela injeção de DMBA durante 12 semanas consecutivas (1 $\mathrm{mg} / 2$ vezes/semana) no sapo (Bufo viridis), descreveu-se que a aplicação de $\beta$-caroteno $(0,05 \mathrm{mg})$ três horas antes da administração do 
carcinogênico, ou seja antes da iniciação, mas não a aplicação tês horas após, foi capaz de bloquear completamente o desenvolvimento de carcinomas hepatocelulares (SADEK e HAYAT, 1996).

No entanto, ASTORG e colaboradores (1996) nāo observaram efeito inibitório do $\beta$-caroteno hidrossolível a $10 \%$ suplementado a raçōes purificadas semiliquidas, ou administrado por via intraperitoneal em uma emulsão hidrossolúvel a $5 \%$, em lesões pré-neoplásicas induzidas em ratos Wistar por um protocolo sequencial de hepatocarcinogênese bastante semelhante ao do hepatocito resistente, e que também empregava DEN como agente iniciante, embora utilizasse posteriormente fenobarbital como agente promotor (ASTORG ef al., 1996).

Todavia, este mesmo grupo de investigadores em publicaçōes nos anos de 1997 e 1998, descreveu, a seguir, que o $\beta$-caroteno hidrossolúvel a $10 \%$ adicionado a dietas purificadas semiliquidas, foi muito eficiente durante a fase de iniciação em reduzir o número e tamanho de focos pré-neoplásicos de hepattocitos induzidos por protocolo de hepatocarcinogênese também semelhante ao modelo do hepatócito resistente, que empregava, entretanto, affatoxina B1 como carcinógeno iniciante ao invés de DEN. De acordo ainda com esses autores, a vitamina A não apresentou qualquer efeito preventivo nessas condiçōes experimentais (GRADELET et al., 1997; 1998).

\subsubsection{Mecanismos de Ação do $\beta$-caroteno Envolvidos com a Carcinogênese}

Foram propostos, até o momento, vários mecanismos que poderiam estar, eventualmente, envolvidos com a ação do $\beta$-caroteno na carcinogênese.

Assim, além da reconhecida função pró-vitaminica A do carotenóide, algumas observaçōes fizeram com que se suspeitasse da existência de mecanismos intrinsecos de ação relacionados com a molécula intacta do carotenóide, como por exemplo: o fato de que a ingestão de vitamina A pré-formada nảo estava associada ao risco de câncer de pulmão, ao contrário do ß-caroteno (PETO ef al, 1981); a observação de que o próprio carotenóide poderia se acumular em diversos tecidos (SHAPIRO et al., 1984); e a constatação de que carotenóides tais como a cantaxantina, que não apresentam atividade pró-vitaminica $A_{1}$ também demonstravam ação anti-carcinogênica (MATHEWS-ROTH, 1982).

Descreveu-se, posteriormente, ação quimiopreventiva intrinseca do $\beta$-caroteno, tanto em modelos experimentais de carcinogênese in vitro (STICH e DUNN, 1986; PUNG et al., 1988; ZHANG et al., 1992) como in vivo (MORENO et al, 1995a; KATSUMURA et al, 1996; RIZZl et al., 1997).

Desta forma, a bioconversão do carotenóide a retinóides e sua ação antioxidante, constituem, na verdade, os mecanismos de proteção mais aventados na literatura.

Portanto, sabe-se que a conversão metabólica do $\beta$-caroteno não apenas nas células do intestino e figado, mas também possivelmente em outros tecidos (WANG et al, 1991), resulta, em última instância, na produção dos ácidos retinóicos todo-trans e 9-cis, capazes de atuarem ao nivel genômico através dos receptores nucleares para o ácido retinóico (RAR) e para o retinóide $X(R X R)$, modulando as expressōes de genes que podem estar, inclusive, envolvidos com processos como a proliferação e diferenciação celulares, importantes para o desenvolvimento da carcinogênese (MANGELSDORF et al. 1994; SILVEIRA e MORENO, 1998).

Além disso, como constituinte do sistema antóxidante do organismo, o $\beta$-caroteno pode atuar, em determinadas condições, como potente neutralizador de espécies reativas de oxigênio e sequestrador de radicais livres, principalmente a baixas pressões parciais de oxigênio, encontradas sob condiçōes fisiológicas na maioria dos tecidos (BURTON e INGOLD, 1984). Assim, o carotenóide pode inibir a peroxidação lipídica no interior de membranas através de 
bloqueio na propagação das reações de oxidaçāo, reagindo preferencialmente com o oxigênio molecular singlete ('O $\mathrm{O}_{2}$ ) e com o radical peroxila (ROO') (BURTON, 1989; ROUSSEAU et al, 1992).

Descreveu-se, portanto, que o $\beta$-caroteno, como modulador do equilíbrio oxidativo do organismo, poderia inibir diversos processos oxidativos relacionados com a carcinogênese, principalmente em suas etapas de iniciaçāo e promoção, sequestrando o oxigênio singlete e radicais livres envolvidos com a formação das neoplasias (PALOZZA e KRINSKY, 1992; ROUSSEAU et al., 1992; SARKAR et al., 1995a; SIES e STAHL, 1995).

Algumas referências na literałura índicam ainda a possibilidade do $\beta$-caroteno exercer uma eventual ação em nivel genômico.

Assim, relatou-se uma açāo indutora do carotenóide na expressão do gene que codífica para a proteina conexina 43 , componente estutural das junçōes tipo hiato, em fibroblastos de camundongo e seres humanos (ZHANG et al, 1992; 1995). Descreve-se que estas junções, que se demonstrou estarem em número reduzido na carcinogênese (KRUTOVSKIKH ef al., 1995), estabelecem comunicaçōes entre as células que possibilitam a passagem de sinais regulatórios do crescimento, dentre outros, envolvidos com o controle da proliferação tanto das células normais como neoplásicas (LOWWESTEIN e ROSE, 1992). Desta forma, relatou-se que o aumento do número das junções tipo hiato se correlaciona com a inibição do crescimento de células quimicamente tansformadas, e que retinóides e carotenóides, incluindo o ß-caroteno, são capazes de induzi-las (HOSSAIN et al., 1993; ZHANG et al., 1995; SIES e STAHL, 1997; STAHL et al., 1997).

Além disso, descreveu-se que o $\beta$-caroteno pode reduzir a expressão de proto-oncogenes em linhagens celulares de neoplasias humanas ou papilomas cutáneos (SCHWARTZ et al, 1993; KATSUMURA ef al., 1996) e do gene p53 mutante (SHKLAR e SCHWARTZ, 1994), bem como aumentar a expressão de proteinas do choque térmico e do fator $\alpha$ de necrose tumoral (TNF- $\alpha$ ), estas últimas relacionadas à induçăo da morte celular programada (SCHWARTZ et al, 1990; SCHWARTZ e SHKLAR, 1992; SHKLAR e SCHWARTZ, 1993; TOBA et al, 1997).

Observou-se, ainda, em ratos submetidos à hepatectomia parcial como modelo experimental de proliferação celular, que o $\beta$-caroteno é capaz de inibir, através de mecanismos pós-transcricionais, a expressão do gene que codifica para a enzima 3-hidroxi-3-metilglutaril coenzima A (HMGCOA) redutase (EC 1.1.1.34) (MORENO et al, 1995b), cuja atividade é considerada etapa crítica para o metabolismo intracelular nāo só do colesterol como ainda de outros derivados do mevalonato, que se relatou também estarem associados com a proliferação celular e a transformação maligna (BROWN e GOLDSTEIN, 1974; SOMA et al., 1992; BENNIS et al., 1993). Constałou-se, também mais recentemente, em cultura in vitro de linhagem de Macrofagos, que o $\beta$-caroteno é efetivamente capaz de inibir a sintese celular do colesterol a partir do [3H]acetato, mas não a partir do [ $\left.{ }^{14} \mathrm{C}\right]$ mevalonato, o que indica que o carotenóide estaria atuando também nessas condições experimentais, através de um efeito inibidor na enzima HMGCoA redutase (FUHRMAN et al., 1997).

Sugeniu-se que estas açōes do $\beta$-caroteno em nivel genômico poderiam ser mediadas, talvez, por uma nova classe de receptores nucleares, ou até mesmo por receptores da família RXR, com afinidade de ligação tanto para retinóides como para carotenóides (ZHANG et al, 1992; ACEVEDO e BERTRAM, 1995; MORENO et al., 1995a; NAVES e MORENO, 1998; SILVEIRA e MORENO, 1998).

Como mecanismos que poderiam estar eventualmente envolvidos com a ação protetora do carotenóide na carcinogênese, descreveu-se ainda sua capacidade de modular a atividade de enzimas relacionadas com a metabolização de xenobióticos (BASU et al., 1987; EDES et al., 1989; 1991; MANORAMA et al., 1993; SARKAR et al., 1994) ou do sistema de defesa antioxidante (SARKAR et al., 1995; VAN LIESHOUT et al., 1996; HE et al., 1997), e de inibir a mutagenicidade e a ocorrência de lesões ou adutos do DNA (MUKHERJEE et al., 1991; 
KRINSKY, 1993; AIDOO et al, 1995; RENNER, 1995; UEHARA et al., 1996; POOL-ZOBEL et al., 1997; SARKAR et al, 1997), bem como a troca de cromátides irmãs, a formação de micronúcleos e de aberrações e translocaçōes cromossômicas, que podem resultar da exposição de linhagens celulares a carcinogênicos (ìvEITBERG ef al., 1985; STICH e DUNN, 1986; KRINSKY, 1989b, SALVADORI et al., 1992; KRINSKY, 1993; SARKAR et al., 1997).

Relatou-se também que $O \beta$-caroteno pode estimular respostas imunes relacionadas com a prevenção do câncer, tais como a proliferação de linfócitos $T$ e $B$, e a citotoxicidade de MACrófagos, de células "killer" naturais e de células T capazes de reconhecer e eliminar células neoplásicas, bem como a secreçäo de fator alfa de necrose tumoral (TNF- $\alpha$ ) e interleucina 1 alfa (IL-1- $\alpha$ ), por células mononucleares do sangue periférico de humanos (TOMTA ef al., 1987; SHKLAR e SCHWARTZ, 1988; BENDICH, 1989; KRINSKY, 1989b; KRINSKY, 1991; ABDEL-FATTH et al., 1993; SANTOS et al., 1996; FERNANDES-CARLOS et al., 1997; HUGHES et al, 1997; KAZl et al. 1997).

Finalmente, demonstrou-se ainda em alguns poucos modelos experimentais, a capacidade do $\beta$-caroteno de inibir a proliferação celular, tanto in vitro como in vivo (MURAKOSHI et al, 1989; PHILLIPS et al., 1993; TANAKA et al, 1994; BIESALSKI e SCHÄFFER, 1997; GROSS et al., 1997; PARK et al., 1997), e de promover a diferencią̧ão de células (NIKAWA et al., 1995; BIESALSKI e SCHÄFFER, 1997; GROSS et al., 1997; PARK et al., 1997). Acredita-se que parte do efeito observado nestes casos possa ser atribuida à conversāo metabólica do ß-caroteno a retinóides ativos, e parte a uma açāo intrinseca diretamente relacionada à molécula do carotenóide.

\subsection{Retinóides}

A "revoluçăo dos retinóides" data do inicio deste século com a elaboração do papel nutricional da vitamina $A$ (BOLLAG, 1996), que corresponde, na verdade, à primeira vitamina lipossolúvel a ser reconhecida, por MCCOLLUM e DAVIS (1913), a partir de experimentos conduzidos em ratos tratados com raçōes às quais se adicionou ou nāo, manteiga, extratos etéreos de gema de ovo, folhas de alfafa, figado ou rim, que em muito melhoraram o crescimento dos animais.

Todavia, nosso conhecimento histórico a respeito desse composto retrocede, provavelmente, a uns 3500 anos atrás. Assim, nesse sentido, já constam, inclusive, menções nos papiros de KAHUN (ca. 1825 a.C.) e de EBERS (ca. 1500 a.C.), a tratamentos de afecçōes oculares através da ingestāo de figado cru ou aplicação tópica de extratos de figado de boi, respectivamente. Além disso, existem evidências de que o primeiro reconhecimento indiscutivel da cegueira noturna ocorreu na Grécia antiga, já havendo HIPÓCRATES (460-327 a.C.) descrito a "nictalopia” em seu segundo livro, denominado "Prognóstico" (WOLF, 1996).

Entretanto, nāo foi senão em 1931, que KARRER e colaboradores (1931) descreveram o isolamento e caracterizaçāo da estutura química da vitamina $A$.

O termo refinóide, introduzido por SPORN e colaboradores (1976), se refere, na verdade, a uma família de substâncias que inclui a vitamina $A$ (retinol) e seus derivados metabólicos naturais, 0 retinaldeido e o ácido retinobico, berm como inúmeros outros derivados sintéticos (IUPAC-IUB, 1982).

A vitamina A consiste em um álcool primário de cadeia longa e que pode se apresentar em uma série de formas isoméricas. Na natureza ocorre, em geral, como retinol na sua forma todo-trans, e com tês caracteristicas estruturais importantes, ou seja, apresentando: (i) um anel $\beta$-ionona, sua extremidade hidrofóbica; (ii) uma cadeia lateral isoprenóide conjugada, que está 
sujeita à isomerização na presença de luz; e (iii) um grupamento terminal polar, que pode ser modificado enzimática ou quimicamente para se tornar um éster, como por exemplo no caso do palmitato de retinila, ou um aldeido, como no refinaideido, ou até mesmo ser oxidado a um metaboblito polar, como no caso do ácido refinóico (ROSS, 1993; BASU e DICKERSON, 1996b).

Na maior parte dos tecidos de animais o retinóide predominante é o palmitato de retinila, embora também possam ocorrer outros ésteres de ácidos graxos, tais como o oleato ou estearato de retinila. A maioria desses metabólitos também ocorre na configuração trans. Além disso, a forma aldeídica 11-cis, ou seja, o 11-cis retinaldeido, e que constitui um cromóforo na retina do olho, bem como diversas formas acidicas, como por exemplo, os ácidos retinóicos todo-trans, 3,4-didesidro- e 9-cis, são metabólitos ațvos do retinol, presentes na maioria, se não em todos os tecidos (BLOMHOFF, 1994).

É justamente a configuração estrutural da vitamina $A$ que lhe confere determinadas propriedades fisicas, importantes não só para a ação do próprio retinol em sistemas biológicos, como também de seus compostos relacionados.

Assim, por exemplo, devido à sua estrutura química a vitamina A sofre facilmente oxidação quando exposta ao ar, e isomerização quando exposta à luz. Além disso, suas propriedades estereoisoméricas são particularmente importantes, por exemplo, para a físiologia da visão (WALD, 1960; DINGLE e LUCY, 1965; BASU e DICKERSON, 1996b).

Fontes importantes de vitamina A pré-formada na alimentação são constituidas exclusivamente por produtos de origem animal, como por exemplo, figado, ovos e leite (OLSON, 1994b). Praticamente nenhum ou muito pouco ácido refinóico pré-formado é encontrado em uma alimentação normal (BLOMHOFF, 1994).

Define-se como uma unidade internacional (UI) de vitamina $A, 0,3 \mu \mathrm{g}$ de retinol todo-trans. Por outro lado, do ponto de vista nuticional, considera-se mais adequado o termo "equivalentes de retinol" (ER), que converte todas as fontes alimentares de vitamina $A$ e carotenóides em uma única unidade. Assim, assume-se, geralmente, que $1 \mu \mathrm{g}$ de retinol equivale biologicamente a 6 $\mu \mathrm{g}$ de $\beta$-caroteno ou $12 \mu \mathrm{g}$ de uma mistura de carotenóides com atividade pró-vitaminica A da alimentação (IUPAC-IUB, 1982; BLOMHOFF, 1994).

\subsubsection{Absorção, Transporte, Metabolismo e Armazenamento de Retinóides Naturais}

Após suas ingestőes, alimentos contendo ésteres de retinila, isto é, vitamina A pré-formada, sofrem hidrólise no lúmen intestinal por duas enzimas pancreáticas, ou seja, pela hidrolase de ésteres de colesterol e pela lipase, com suas consequentes liberações e agregaçōes em glóbulos de lipídeos (ERLANSON e BORGSTOM, 1968; SILVEIRA e MORENO, 1998).

Nesse sentido, foram ainda descritas no rato, e mais recentemente em seres humanos, duas outras enzimas presentes na membrana apical da bordadura em escova do enterocito também capazes de realizarem hidrólise dos ésteres de retinila, uma delas estimulada principalmente pelo sal biliar taurocolato, e atuando preferencialmente em ésteres de retinila de cadeia curta, e a outra, pelo sal biliar desoxicolato, agindo mais especificamente em esteres de retinila de cadeia longa (RIGTRUP ef al., 1994).

A seguir, o retinol livre não-esterificado resultante pode ser absorvido pelos enterócitos por difusão passiva, quando presente no lúmen intestinal em concentraçōes elevadas, ou por mecanismo de difusão facilitada mediada por carregador, quando em concentraçōes fisiológicas (DEW e ONG, 1994). 
Evidências demonstram que menos do que $75 \%$ do retinol ingerido são absonidos, e que isto depende do tipo e quantidade de gordura presente na alimentação (BLOMHOFF et al., 1991; BLOMHOFF, 1994).

No interior do enterócito, após sua absorção o retinol pode sofrer esterificação principalmente com ácidos graxos de cadeia longa tais como o ácido palmítico ou esteárico, através das atividades das enzimas lecitina:retinol aciltransferase (LRAT), que utiliza como fonte de ácido graxo o grupamento acila na posiçảo sn- 1 da fosfatidilcolina (MACDONALD e ONG, 1988), e da enzima acil:CoA retinol aciltransferase (ARAT), que, por sua vez, utiliza grupamentos acila livres (HELGERUD et al., 1983).

Por outro lado, em sua forma livre descreveu-se que o retinol poderia ter efeitos deletérios nas células (ONG, 1994). Assim, tão logo no interior das mesmas este se liga com elevada afinidade a duas proteinas citoplasmáticas, ou seja, às proteinas ligadoras de retinol celular CR8P e CRBPII, que, apesar de apresentarem $56 \%$ de homologia entre suas sequências de aminoácidos, diferem, entretanto, em suas propriedades fisiológicas (ROSS, 1993; ONG, 1994).

Descreveu-se, ainda, que a proteina ligadora de retinol celular CRBPII se localiza exclusivamente no interior do enterócito, onde representa cerca de $1 \%$ da proteína citossólica, enquanto a CRBP pode ser encontrada em diferentes tecidos tais como na musculatura do intestino delgado, nos rins, testículos, pulmões e no figado (CROW e ONG, 1985; WOLF, 1991; ROSS, 1993). Além disso, relatou-se que as duas proteinas, ou seja CRBPIl e CRBP, são também capazes de se ligar ao retinaldeido, a primeira com a mesma afinidade que demonstra para com o retinol, e a segunda, sendo ainda capaz de se ligar ao isómero 13-cis do retinol e ao 3-desidroretinol. Todavia, este aldeido pode deslocar o retinol apenas de sua ligação com a CRBPII (MACDONALD e ONG, 1987).

No interior do enterbcito o retinol ligado à CRBPII sofre esterificação principalmente pela açāo da enzima LRAT. Entretanto, quando presente em altas concentraçöes intracelulares o refinol satura esta proteína ligadora, sendo, então, esterificado pela enzima ARAT (BLOMHOFF et al., 1991).

A seguir, os ésteres de retinila sintefizados são incorporados em quilomicrons. Estes são transferidos para o sistema linfático por exocitose, atingindo a circulaçāo sistêmica, onde são metabolizados em remanescentes de quilomicrons, e retomando ao figado retendo a maior parte dos ésteres de retinila que carregam (HENDRIKS, 1996; GERSTER, 1997b). Estes remanescentes parecem ser também importantes para a liberação direta de refinol em tecidos extrahepáticos caracterizados por intensa proliferação celular e diferenciaçāo tais como o baço e a medula ossea, bem como para o pulmão, rim, tecido adiposo, musculatura esquelética e leucócitos da periferia (BLOMHOFF et al., 1990a; BLOMHOFF, 1994; GERSTER, 1997b). Por outo lado, o ácido retinóico, produto de oxidaçāo do refinaldéido, é absorvido diretamente para o sistema tibutário da veia porta, sendo transportado no sangue ligado à albumina (BLOMHOFF et al., 1990a).

Portanto, cerca de 70 a $80 \%$ dos ésteres de retinila presentes nos remanescentes de quilomicrons são captados pelo figado, onde se descreveu a presença de dois diferentes tjpos de células particularmente envolvidas com o metabolismo da vitamina A, ou seja, as assim chamadas células perissinusoidais estreladas, ou de Ito, responsáveis pelo armazenamento do refinol na forma de ésteres especialmente na regiāo periportal, e os hepatócitos, diretamente envolvidos com a captação dos remanescentes de quilomicrons e com a sintese e secreção da proteína ligadora de retinol (RBP), uma proteína de $21 \mathrm{kDa}$ com 182 residuos de aminoácidos e apenas um sítio de ligação para o retinol (BATRES e OLSON, 1987; BLOMHOFF et al., 1991).

Acreditava-se até há nāo muitos anos atrás que os hepatócitos constituiam o principal, se não o único, sítio de síntese de RBP. Entretanto, sabe-se agora que células de muitos outros tecidos apresentam mRNA para RBP, ou seja, parecem também sintetizar essa proteina (SOPRANO et al., 1986; BLOMHOFF, 1994). 
No interior dos hepatócitos os ésteres de retinila são subsequentemente hidrolizados, possivelmente pelas enzimas retinil éster hidrolase ácida e neutra presentes na membrana plasmática elou endossomos, e o retinol formado é transferido para o reticulo endoplasmático, onde se liga à RBP para posterior secreçāo para o exterior da célula (RONNE et al., 1983; GAD e HARRISON, 1991; BLOMHOFF, 1994). A interação do retinol com a RBP (holo-RBP) serve para solubilizar a vitamina no sangue e proteger a molécula de refinol contra eventual alteração oxidativa (BASU e DICKERSON, 1996b). Entretanto, antes de ser liberado para a circulação sistêmica o complexo retinol-RBP se associa, no lúmen do retículo endoplasmático, a uma proteina homotetramérica de $55 \mathrm{kD}$ a sintetizada pelo figado e que também apresenta um sítio de ligação com elevada afinidade pela tiroxina, a transtirefina (TTR), previamente conhecida como pré-albumina, que reduz sua filtração glomerular (BLOMHOFF of al., 1991; HENDRIKS, 1996).

A molécula de retinol circula diversas vezes entre o figado e os tecidos extrahepáticos, antes de ser irreversivelmente degradada. Como a meia-vida da RBP no plasma é menor do que a do retinol, isto implica, entretanto, na necessidade de síntese adicional de RBP para que ocorra recirculação de vitamina A (LEWIS et al., 1990; ROSS, 1993).

Assim, o complexo refinol-RBP liberado pelos hepatócitos tem a função básica de satisfazer as necessidades de vitamina $A$ do organismo, sendo o restante armazenado nas células perissinusoidais estreladas, que contêm cerca de $80-90 \%$ do total hepático de retinol, principalmente na forma de esteres de retinila (BATRES e OLSON, 1987; BLOMHOFF e WAKE, 1991).

Os mecanismos atavés dos quais as células captam o retinol presente no complexo retinolRBP-transtiretina são ainda controversos (ROSS, 1993; HENDRIKS, 1996; SILVEIRA e MORENO, 1998), tendo-se demonstrado que isto pode ocorrer com (SMELAND et al., 1995) ou sem (NOY e XU, 1990; NOY e BLANER, 1991) a presença de receptores especíicos para a RBP, presentes nas membranas plasmáticas.

De uma forma geral, cerca de $10-20 \%$ da vitamina A ingerida na alimentação não são absorvidos. Do restante, aproximadamente $20 \%$ aparecem nas fezes através da bile, $17 \%$ são

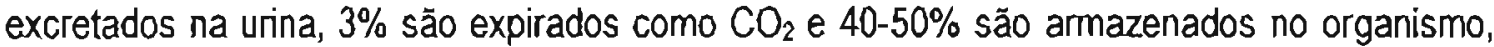
primariamente no figado (BASU e DICKERSON, 1996b).

Portanto, a ingestão de retinol em excesso por períodos prolongados pode causar lesão hepática, tendo-se sugerido que a toxicidade da vitamina $\mathrm{A}$ pode ser devida à sua elevada concentração excedendo a capacidade de ligação da molécula de RBP, ou de CRBP, com consequente precipitação do retinol e alteração na estrutura e funçăo normal das membranas celulares (BLOMHOFF, 1994; LETTINGA et al., 1996). Um outro eventual mecanismo que poderia ser responsável pela toxicidade seria atuavés da interação dos retinóides com seus respectivos receptores nucleares (SILVEIRA e MORENO, 1998).

Da mesma forma que no intestino delgado, o retinol ligado à CRBP pode ser esterificado no figado, pelas enzimas LRAT e ARAT (BLOMHOFF et al., 1991). Além disso, descreveu-se que a CRBP está também envolvida com a conversão do retinol hepático em ácido retinóico, que em elevadas concentraçōes pode inibir a conversão da vitamina $A$ em retinaldeido, além de estimular a sintese de ésteres de retinila (NAPOLI, 1993; WANG et al., 1993).

Assim, no interior das células o retinol pode ser armazenado na forma de ésteres de retinila, pode ser reciclado novamente para a circulação sistêmica ou ser oxidado a ácido retinóico, o que envolve, inicialmente, a oxidação da vitamina $A$ em retinaldeido, através das atividades das enzimas álcool desidrogenase e retinol desidrogenase (BLOMHOFF, 1994; SILVEIRA e MORENO, 1998).

Observou-se que o retinaldeido, por sua vez, pode ser oxidado a ácido retinóico pela enzima retinaldéido desidrogenase e membros da família do sistema citocromo P450, ou seja, as suas formas $1 A 1$ e 1A2, e que diversas outras isoenzimas desse sistema podem participar, a 
seguir, do metabolismo do ácido retinóico, produzindo compostos polares tais como os ácidos retinóicos $4-\mathrm{OH}$ e $18-\mathrm{OH}$, que serão posteriormente excretados na urina ou conjugados no figado com o ácido glicurônico, com subsequente excreção biliar na forma de glicuronideos (ROBERTS et al.، 1992; ROSS, 1993; EL-AKAVI e NAPOLI, 1994; DUESTER, 1996).

Diversos desses compostos, apesar de constituirem metabólitos do ácido retinóico, apresentam ainda atividade biológica Relatou-se ainda que o principal destes glicuronideos, o retinoil Buglicuronideo é capaz de estimular o crescimento de animais deficientes em vitamina A e induzir in vitro e in vivo a diferenciação de células epitelias (FORMELU et al, 1996; BARUA, 1997).

O ácido retinóico todo-trans pode também dar origem no organismo ao isômero 9-cis, que se liga com elevada afinidade aos receptores nucleares para retinóides, capazes de regularem respostas celulares. Discute-se, entretanto, se este processo de isomerizaçāo ocome espontaneamente ou através de atividade enzimática (NAPOU, 1996a; 1996b; MERTZ ef al., 1997 ).

Relatou-se, ainda, que as células de diferentes tecidos tais como do figado, cérebro, ovário, testiculos, útero e rins sintetizam uma proteina que se liga ao ácido retinóico celular (CRABP), e que tem afinidade de ligação principalmente pelo isômero todo-trans, mas que também é capaz de se ligar a seus isômeros 9-cis e 13-cis, bem como a seu metabólito polar, 0 ácido 4OH-retinóico (FIORELLA e NAPOLI, 1994). Apesar de sua verdadeira função não estar ainda devidamente esclarecida, sugeriu-se que esta proteina talvez pudesse estar envoivida com o tansporte do ácido retinóico do citossol para o núcleo ou, até mesmo, que estivesse mais diretarnente relacionada com a homeostase do ácido retinóico no interior da célula, sequestrando-o e limitando sua distribuição e efeitos biológicos (ROSS, 1993; NAPOLI et al., 1995).

Além disso, descreveu-se a existência de uma outra proteína celular com afinidade de ligação pelo ácido retinóico, a CRABPIl, com propriedades semeihantes às da CRABP, e detectável durante a embriogênese, mas cuja localizaçāo se restringe à pele, em adultos (ASTRÖM et al., 1991).

\subsubsection{Propriedades Biológicas dos Retinóides Naturais}

Reconhecese, há muitos anos, que a vitamina $A$ é um nutriente essencial a animais, necessário à espermatogénese e ao desenvolvimento embrionário adequados, à promoção do crescimento de uma forma geral, e à manutenção da integridade do sistema imune e da função visual, bem como da proliferação celular e diferenciação nomais (OLSON, 1994c; SPORN et al, 1994).

Com o decorrer do tempo, tornou-se também claro que não só o retinol, como também outros refinóides naturais podem apresentar propriedades biológicas especificas. Assim, sabe-se que o retinol, retinaldeido e ésteres de retinila, que são interconversiveis, desempenham papéis na visão e espermatogênese (OLSON, 1994c; SPORN ef al., 1994; BARUA, 1997). Em contrapartida, a forma ácida da vitamina $A$, ou seja, $O$ ácido retinóico, pode substituir a vitamina $A$ quanto a seus papéis no crescimento e desenvolvimento, mas não é ativo na visão e reprodução (BASU e DICKERSON, 1996b).

A falta de ácido retinóico pode causar sintomas de deficiência de vitamina A, mas seu excesso pode ser tóxico ao organismo. Da mesma forma, a deficiência de vitamina A pode resultar em enfermidades, cegueira e até morte, e seu excesso culminar em hipervitaminose, bem como em teratogenicidade (OLSON, 1994c; SPORN et al., 1994).

Assim, diversos estudos demonstraram que a vitamina A é necessária ao crescimento e desenvolvimento normais, e sua deficiência se expressa após poucas semanas, em porcos, gatos, galináceos e outras espécies de animais, como anorexia seguida de rápida perda de peso e interrupção no crescimento (GERSTER, 1997b). 
No olho a vitamina A tem uma ação especifica, altamente complexa, para a visão no escuro. Associado à proteina opsina, o isômero 11-cís do ré̂naldeído, derivado natural da vitamina $A$, forma a rodopsina, um pigmento visual sensivel à luz localizado nos bastonetes da retina. Após exposição à luz os pigmentos visuais se desintegram liberando sinais de energia que se traduzem na imagem visual, formado-se, a seguir, no ciclo da visāo, nova rodopsina. Um dos primeiros sinais da deficiência de vitamina A é a nictalopia (cegueira noturna) ou menor capacidade visual à luz difusa (SPORN et al., 1994; BASU e DICKERSON; 1996b; GERSTER, 1997b).

Outra propriedade biológica importante da vitamina A é seu papel no controle da proliferação celular e diferenciação. Há muitos anos sabe-se, por exemplo, que sua deficiência resulta em queratinização de epitélios ciliares secretantes de muco e em outras alteraçōes epiteliais, inclusive metaplasias semelhantes àquelas causadas por carcinogênicos químicos, em tecidos sensiveis como os da traquéia, pele, glândula salivar, córnea e testículos (BASU e DICKERSON, 1996b; DE LUCA et al., 1997; GERSTER, 1997b).

No olho, lesões da conjuntiva e da cómea, tais como a xerose, manchas de Bitot, erosões e, finalmente, a cegueira, resultam de atteraçöes na diferenciaçāo do epitélio superticial (BASU e DICKERSON; 1996b).

Alteraçōes na divisão e diferenciação celulares podem também afetar células-mãe ("stem cells $\left.{ }^{p}\right)$, resultando, por exemplo, em deficiência de hematopoiese. A deficiência de vitamina A está então frequentemente associada com anemia, caracterizada por ferro sérico reduzido, baixa capacidade de ligaçăo do ferro, mas deposição aumentada desse mineral no fígado. Esta responde prontamente à suplementação com vitamina A (GERSTER, 1997b).

Da mesma forma, a deficiência de vitamina A pode resultar em alteraçōes na imunidade, tanto humoral como celular, bem como em respostas anomais de reparo tecidual, com consequente aumento da severidade de infecções (ROSS, 1992; ROSS e STEPHENSEN, 1996).

Acredita-se que essa grande diversidade de efeitos biológicos dos retinóides seja em parte mediada, em última instância, por proteínas receptoras nucleares que fazem parte da numerosa familia de receptores para os hormônios esteróides e tireoidianos, bem como para a vitamina D, e que atuam como fatores de transcrição modulando a expressão gênica (EVANS, 1988; MANGELSDORF, 1994; SILVEIRA e MORENO, 1998).

Essa nova era da pesquisa em vitamina A teve seu início ao final da década de 80 deste século, por ocasião do descobrimento quase que simultâneo, por dois grupos independentes de pesquísa, um liderado por P. CHAMBON em Strasbourg (França) e o outro por R. M. EVANS em San Diego (EUA), da existência de receptores nucleares para o ácido retinóico (KASTNER et al. 1994; MANGELSDORF et al., 1994; WOLF, 1996).

Estes atuam como fatores de transcrição dependentes de seus ligantes, e são estruturalmente semelhantes, apresentando uma região AB próxima à extremidade amino-terminal da proteina, importante para a ativaçāo da transcrição, uma região $C$ contendo dois motivos ligadores de żnco envolvidos com a ligaçāo do receptor a sequências específicas do DNA, e uma regiāo $E$ próxima à extremidade carboxila-terminal, responsável pela ligação do receptor a seu ligante e para a formação de dímeros. As funçōes das regiōes $D$ e $F$ desses receptores não foram, entretanto, ainda suficientemente esclarecidas (LEID et al., 1992).

Descreveu-se ainda a existência de dois tipos de receptores para retinóides, os assim chamados receptores RAR e RXR, com seus respectivos subtipos $\alpha, \beta$ e $\gamma$, todos codificados por genes individuais. Os receptores RAR podem se ligar ao ácido retinóico todo-trans e a seu isômero 9-cis, bem como ao 4-oxo-retinol, um metabólito da vitamina A, mas não apresentam, entretanto, afinidade pelo isômero 13-cis do ácido retinóico. Já os receptores RXR apresentam afinidade pelo isômero 9-cis do ácido retinbico, mas não pelo isômero todo-trans (GUDAS, 1994; MANGELSDORF, 1994). 
Além dos isômeros todo-trans e 9-cis do ácido retinóico, os receptores RAR e RXR podem se ligar com diferentes graus de seletividade, a uma variedade de retinóides sintéticos (LOTAN et al., 1995).

Estes receptores variam em termos de suas distribuições nos vários teciüus durante 0 desenvolvimento e na vida adulta, tendo-se, portanto, sugerido que podem apresentar funçōes distintas na regulação da transcrição gênica. Desta forma, obsenou-se, por exemplo, expressão dos genes que codificam para os receptores RAR $\alpha$ e RXR em diversos tecidos de embriōes e animais adultos, enquanto a expressão do gene para o receptor RAR $\beta$ foi detectada nos rins, músculo e próstata de animais adultos (LEID et al., 1992; MANGELSDORF, 1994). Por outro lado, constatou-se expressão do gene que codifica para o receptor RARy na pele, o que sugere seu envolvimento na morfogênese e diferenciação epitelial (RUBERTE et al., 1990).

Além disso, relatou-se em um estudo in vitro em células F9, em que se realizou mutação no gene para o receptor RARy, perda da expressão de genes que respondem a retinóides, tais como dos genes para as proteinas Hoxa-1, Hoxa-3, laminina B1 e colagenase IV, bem como redução no metabolismo do ácido refinóico todo-trans a seus derivados polares. Nesse mesmo estudo, a realização de mutação no gene para o receptor RAR $\alpha$ resultou em aumento do metabolismo do retinóide e redução na expressão dos genes para CRBPII e Hoxb-1, o que indica que cada subtipo de receptor pode apresentar uma função especifica na modulaçāo da expressão gênica (BOYLAN et al., 1995).

Genes da familia Hox codificam para proteinas que atuam como fatores de tanscrição, e cujas expressōes estão envolvidas com o desenvolvímento embrionário adequado (MARSHALL et al., 1996).

Observou-se, ainda, que estes receptores nucleares para retinbides podem modular a transcrição ligando-se como dímeros a sequências nucleotídicas especificas presentes nos elementos de resposta de seus genes alvos (MANGELSDORF, 1994).

Os receptores RXR são os únicos capazes de formar homodimeros (RXR-RXR), atuando nesta forma em genes tais como CRBPIl e apo A1. Formam tambem heterodimeros com os receptores $R A R$ ( $R X R-R A R$ ), para a vitamina $D$ (RXR-DR), para o hormônio tireoidiano (RXR-TR) e com o receptor proliferador de peroxissomos ativado (RXR-PPAR). Heterodimeros são mais estáveis que homodimeros e apresentam maior afinidade com regiões promotoras de genes presentes no DNA (MANGELSDORF, 1994; CHAMBON, 1996).

Descreveu-se, ainda, que o heterodimero RXR-RAR e o homodímero RXR-RXR reconhecem sequências especificas de nucleotideos presentes em genes que respondem aos retinóides. Tais elementos consistem de tês ou mais repetiçōes da sequência de bases AGGTCA. As sequências do elemento de resposta para o ácido retinćico (RARE), ou seja, para o heterodimero RXR-RAR, encontram-se separadas por 2 ou 5 nucleotideos (DR2 e DR5), sendo, inclusive, o espaçamento DR5 o mais frequente, enquanto que o elemento de resposta para o homodimero RXR-RXR (RXRE) reconhece essas mesmas sequências quando espaçadas por apenas 1 nucleotideo (DR1) (MANGELSDORF, 1994). RAREs e RXREs são também capazes de se ligarem a complexos de homo ou heterodimeros de receptores nucleares brfãos tais como a proteina regulatória apo A1 (ARP-1), receptores nucleares do hepatócito (HNF-4) e a proteina 3 v-erbA-relacionada (EAR 3) (NAKSHATR) e CHAMBON, 1994; CHAMBON, 1996; JIANG e SLADEK, 1997).

Entende-se por receptores órfăos aqueles membros da familia de receptores para hormônios esteróides/tireoidianos/retinóides, para os quais ainda não se determinou um ligante especifico (GUDAS, 1994).

Assim, observou-se que retinóides podem tanto estimular como inibir a transcrição gênica. 
Exemplos de genes ativados pelo ácido retinóico e seus receptores, por processo denominado de transativação, são os genes que codificam para o hormônio do crescimento e a oxitocina, para enzimas como a fosfoenolpiruvato ou álcool desidrogenase e os genes para as proteinas CRBP e CRABPII, bem como para algumas proteinas constituintes da matriz extracelular, tais como determinadas colagenases e a laminina B (GUDAS et al., 1994). Neste caso, estes podem atuar de forma direta sintetizando uma proteína após ligação dos receptores RAR ou RXR ao elemento de resposta do respectivo gene no DNA, ou indireta, produzindo um fator de transcrição que atuará, a seguir, nos genes alvos (SILVEIRA e MORENO, 1998).

Por outro lado, exemplos de genes cujas transcrições são inibidas por retinóides são os genes para os fatores de crescimento IGF-1 e TGF- $\alpha$ (GUDAS ef al., 1994), bem como o gene para a proteína Gla da matriz extracelular (KIRFEL et al., 1997).

Descreveu-se, além disso, que as ações dos retinóides na transcrição gênica dependem das quantidades e tpos dos receptores presentes, da mesma forma que dependem das concentrações de seus ligantes. Assim, na presença de uma concentração reduzida do ácido retinóico 9-cis elou de grandes quantidades de receptores RAR, ocorte a formaçāo preferencial do heterodímero RXR-RAR, que nessas condições pode, inclusive, se ligar ao elemento de resposta RXRE, inibindo a transcrição gênica, como por exemplo no caso da proteína CRBPI (MANGELSDORF et al., 1991).

Relatou-se, ainda, que retinóides podem também atuar em nivel pós-transcricional através do aumento da estabilidade (ZHOU et al., 1994) ou meia-vida do RNA mensageiro (BEX et al., 1995), e regulando o processamento de precursores de transcritos (JARROUS e KAEMPFER, 1994).

Além disso, através de um processo denominado de transrepressão, observou-se que retinóides podem inibir alguns oncogenes e colagenases, bem como o fator de crescimento TGF- $\beta 1$ através da interação dos receptores RAR e RXR com o complexo protéico AP- 1 , um dimero das proteinas codificadas pelos proto-oncogenes fos e jun em geral envolvido com o controle da proliferação celular e da inflamação, com consequente perda da capacidade desse fator de transcriçăo de se ligar a elementos de resposta de seus respectivos genes (SALBERT et al., 1993; GUDAS et al., 1994).

As regiões dos receptores para retinóides que contribuem para com o antagonismo da função do complexo AP-1 não são idênticas àquelas envolvidas com a ativação transcricional (NAGPAL et al., 1995).

\subsubsection{Retinóides e Câncer}

\subsubsection{Estudos em Humanos}

Devido a seu envolvimento com o controle da proliferação e diferenciação celular, há alguns anos tem havido bastante interesse em se esclarecer o papel da vitamina A na carcinogênese humana, tendo sido conduzidos, consequentemente, diversos estudos epidemiológicos observacionais que procuraram examinar a relaçāo ente a ingestăo de vitamina A e o risco para o câncer.

Entretanto, de uma forma geral, as evidências foram até o momento inconclusivas nesse sentido, não havendo, inclusive, muitas dessas investigações estabelecido distinções entre a ingestāo de vitamina $A$ pré-formada e a de carotenóides.

Assim, BJELKE (1975) foi o primeiro a relatar na líteratura, evidências epidemiológicas sugestivas de que a vitamina A poderia ter um efeito protetor contra o câncer de pulmão, e que se 
basearam em um inquérito enviado a 8278 noruegueses em que estes eram questionados a respeito de seus hábitos alimentares e de tabagismo, bem como em um indice de ingestão total de vitamina A calculado, a seguir, a partir do consumo de vegetais e laticínios referido por essa população.

Nos anos subsequentes, diversos outos estudus sugeriram que o maior consumo de vitamina A na alimentaçāo poderia proporcionar proteçāo contra o câncer de pulmāo.

Desta forma, oois anos após, em um estudo tipo caso-controle conduzido em mulheres chinesas de Singapura, observou-se a existência de uma associação inversa entre o consumo de hortaliças, ricas em carotenóides com atividade pró-vitamínica A, e o câncer de pulmão (MACLENNAN et al., 1977).

Preparaçōes farmacológicas de vitamina A também pareceram conferir algum beneficio, ao se comparar suas utilizaçóes entre 800 individuos recém diagnosticados como portadores de cânceres e 3.433 pacientes com condições não-malignas, observando-se nos homens, uma associação negativa entre o desenvolvimento de câncer e o uso frequente dos suplementos (SMITH e JICK, 1978).

Já no inicio dos anos 1980s, tornou-se evidente a existência de uma associação mais especificamente entre o $\beta$-caroteno e redução do risco para câncer de pulmāo, mas não para o retinol.

Assim, em um estudo prospectivo conduzido em 1.954 homens de meia-idade e que foram seguidos por 19 anos, descreveu-se que a ingestāo de $\beta$-caroteno na alimentação relacionava-se inversamente com a incidência de câncer de pulmāo, antes e após ajuste para o consumo de cigarros. Por outro lado, não se observou nessa investigaçāo, relação entre a ingestāo de vitamina A pré-formada e o risco para câncer de pulmão (SHEKELLE et al., 1981).

Em uma investigação realizada no Havai em 102 mulheres e 230 homens portadores de câncer de pulmão, bem como em 288 mulheres e 597 homens controles, demonstrou-se ainda uma associação negativa claramente dose-dependente, entre a ingestão de $\beta$-caroteno na alimentação e o risco para o câncer de pulmāo nos dois sexos. Nāo se observou, entretanto, associação ente o retinol e o câncer de pulmāo (LE MARCHAND et al., 1989).

Por outro lado, em um estudo conduzido em 106 pacientes portadores de câncer epidermóide de pulmão e 212 controles, observou-se que os consumos de vitamina $A$ pré-formada e de $\beta$-caroteno estavam associados, de forma independente e significante, a um menor risco de desenvolvimento dessa neoplasia (DARTIGUES et al., 1990). Portanto, ao mesmo tempo que esta investigação confirmou o papel protetor do $\beta$-caroteno, também sugeriu, entretanto, que a vitamina A pré-formada exerce o mesmo efeito.

Mais recentemente, em uma revisão de estudos epidemiológicos observacionais publicados na literatura, descreveu-se que de sete investigacões tipo caso-controle que avaliaram o rísco para câncer de bexiga e a ingestāo de vitamina $A$ pré-formada na alimentaçāo, quatro não observaram associação, duas constataram redução de risco e uma detectou aumento do mesmo, embora nãosignificante, o que talvez possa sugerir que a maior ingestảo de retinol pode reduzir o risco para o câncer de bexiga. Todavia, relatou-se também nessa mesma revisão, que as evidências epidemiológicas publicadas até então na literatura, apontavarn para o fato de nâo haver, possivelmente, uma relação entre a ingestão de vitamina A pré-formada na alimentação e os riscos para os cânceres de pulmão, estômago, mama e colo uterino (WORLD CANCER RESEARCH FUNDIAMERICAN INSTITUTE FOR CANCER RESEARCH, 1997e).

Diversos estudos epidemiológicos comparafivos demonstraram, ainda, a existência de uma associaçäo entre as concentraçoes séricas reduzidas de retinol ou $\beta$-caroteno, e o desenvolvimento de câncer em numerosos sítios, incluindo o pulmão, cavidade orallorofaringe, esôfago, trato gastrointestinal, próstata, colo uterino, ovário e mama. En relação ao carotenóide, essas relações parecem preceder o desenvolvimento da moléstia. Entretanto, as evidèncias nesse sentido quanto ao 
refinol são bem menos consistentes e, em alguns casos, as associações podem representar mais uma consequência do que a causa do câncer (HONG e ITRI, 1994).

Não existem também evidências consistentes até o momento de que a suplementação com retinol possa reduzir o risco de desenvolvimento de qualquer tipo de câncer. Ao contrárío, no estudo CARET ( $\beta$-Carotene and Retinol Efficacy Trial) de intervençảo primária, conduzido em milhares de individuos com história prévia de tabagismo ou exposição ao asbesto no ambiente de trabalho, e aos quais se administrou diariamente $25.000 \mathrm{Ul}$ de retinol associadas a $30 \mathrm{mg}$ de $\beta$-caroteno, descreveu-se um aumento significante do risco para câncer de pulmão no grupo suplementado, em comparação ao grupo que recebeu apenas placebo (OMENN et al., 1996).

Em contrapartida, relatou-se que no estudo Wittenoom, conduzido na Austrália, o câncer de pulmão foi menos frequente em trabalhadores de minas de asbesto que receberam retinol (palmitato de retinila $25.000 \mathrm{Ul} / \mathrm{dia}$ ), do que naqueles que receberam $\beta$-caroteno ( $30 \mathrm{mg} / \mathrm{dia}$ ), embora a diferença não tenha alcançado significância estatistica nesse caso (DE KLERK, 1998).

Já em duas investigações realizadas em Linxian, onde se procurou avaliar 0 efeito da suplementação com refinol (palmitato de retinila; 5000 Ulidia), em combinação com o zinco ou outras vitaminas e microelementos, na prevenção dos cânceres de estômago e esôfago, extremamente frequentes nas populaçōes dessa região da China, não se constatou qualquer efeito benéfico por parte da vitamina $A$, até mesmo quando já existiam anteriormente deficiências nutricionais estabelecidas (BLOT et al., 1993; LI et al., 1993).

Dois outros estudos de intervenção conduzidos nos EUA descartaram um efeito benéfico do retinol (25.000 Ul/dia) em relação ao carcinoma cutâneo de células basais. Observou-se, por outo lado, uma redução de $25 \%$ no risco de desenvolvimento do carcinoma de células escamosas, uma neoplasia mais agressiva que a anterior, em individuos que apresentavam risco moderado de desenvolvimento de carcinomas de pele, embora individuos com alto risco não tivessem apresentado qualquer beneficio (LEVINE et al., 1997; MOON et al., 1997).

Deve-se ressaltar, entretanto, que apesar de bem projetados e conduzidos, esses seis estudos de intervenção primária tiveram suas limitaçōes. Assim, por exemplo, nos estudos CARET e Wittenoom não fol possivel a inclusão de grupos placebo. Todos os ensaios, exceto os de Linxian, foram interrompidos ou modificados antes do que inicialmente planejado. Além disso, estes foram conduzidos em individuos de alto-risco, o que impossibilita a extrapolação dos resultados obtidos para a população geral.

Quanto à prevenção do desenvolvimento de novos cânceres primários ou de recorrência, procurou-se avaliar na Itália, em 1993, o efeito adjuvante de altas doses de vitamina A em 307 pacientes portadores de câncer pulmonar grau I de células nāo-pequenas. Após a cirurgia, estes foram distribuidos aleatoriamente em dois grupos, um tratado com doses orais de palmitato de retinila ( 300.000 Ulidia) e o outro que não recebeu tratamento. Após 46 meses de seguimento, $37 \%$ dos indivíduos tratados e $48 \%$ dos não tratados apresentaram uma recorrência ou desenvolvimento de novos cânceres primários. Dezoito pacientes do primeiro grupo desenvolveram novos cânceres primários, enquanto isto ocorreu em 33 indivíduos do grupo controle. $O$ inicio do desenvolvimento de novos cânceres primários foi ainda significantemente retardado no grupo tratado com a vitamina A (PASTORINO et al., 1993).

Já em 1994, avaliou-se, nos EUA, a eficácia do acetato de retinila quando administrado em doses diárias de 5000 Ul ou 40.000 Ul combinadas com outras vitaminas ou o zinco, em reduzir recorrências de carcinomas da bexiga. Após 12 meses de tratamento, apesar da sobrevida ter sido semelhante nos dois grupos, as taxas gerais de recortência foram de $80 \%$ no grupo tratado com baixas doses de vitamina $\mathrm{Ae}$ de $40 \%$ no tratado com altas doses diárias (LAMM et al., 1994).

Entretanto, descreveu-se que a vitamina A por via oral nāo foi capaz de aumentar a sobrevida de pacientes portadores de melanoma maligno cutâneo em sua fase inicial após 
18 meses de tratamento (MEYSKENS ef al., 1994), nem de prevenir a recidiva ou desenvolvimento de novos cânceres primários de cabeça e pescoço (JYOTHIRMAYI et al., 1996)

Por outro lado, em se tratando de lesões pré-neoplásicas, relatou-se que tanto a vifamina A como o $\beta$-caroteno foram capazes de reduzir a frequência de células exfoliadas da cavidade oral que apresentavam micronúcleos (STICH et al, 1984a, 1984b; STICH e ROSIN, 1984), bem como de reverter e suprimir a leucoplaquia, uma condição pré-cancerosa frequentemente associada com o desenvolvimento do câncer oral (STICH ef al., 1988a, 1988b). Apesar do B-caroteno ter apresentado por si só alguma atividade, a combinação desse carotenóide com baixas doses de vitamina A foi mais efetiva (STICH et al., 1988b, 1991).

Além disso, relatou-se que o tatamento de lesões pré-neoplásicas da pele com refinol (25.000 Ul/dia), resultou em diminuição significante na incidência de carcinomas de células escamosas, em comparação ao grupo controle (LOTAN, 1996).

Quando os estudos iniciais com a vitamina A foram conduzidos, doses terapêuticas resultaram entretanto na sindrome da hipervitaminose $A$ aguda, fazendo com que as atençōes e esforços se focalizassem na síntese de derivados menos tóxicos do retinol.

Nesse sentido, o primeiro desses compostos a ser sintetizado, e que também constitui um derivado natural da vitamina $A$, foi 0 ácido retinóico todo-trans. Descreve-se que os ácidos retinóicos todo-trans e 13-cis, bem como a 4-hidroxifenil retinamida (4-HPR), podem ser considerados, hoje em dia, como retinóides de primeira geração. Já os retinóides de segunda geraçāo são constituídos por compostos aromáticos do tipo etretinato e seu principal metabólito, a atretina. Mais recentemente, foram também utilizados retinóides de terceira geração em ensaios clínicos, os assim chamados arotinóides, uma classe de compostos retinóides poliaromáticos (HONG e ITRI, 1994).

Desta forma, observou-se nos últimos anos que uma série de isômeros e derivados sintéticos do ácido retinóico apresentou atividade na quimioprevenção e no tratamento de lesões pré-neoplásicas, bem como na terapêutica de algumas formas de câncer, especialmente na leucemia promielocitica aguda (HONG e ITRI, 1994; WOLF, 1996; SILVEIRA e MORENO, 1998).

Assim, evidências clínicas têm demonstrado, por exemplo, a eficácia do ácido retinóico todo-trans no tratamento de lesões pré-neoplásicas da pele ou do colo uterino, e do ácido retinóico 13-cis na prevenção de lesōes pré-neoplásicas da laringe e do câncer de pele em pacientes com xeroderma pigmentoso, bem como nos tratamentos da leucoplaquia oral (LIPPMAN et al., 1995) e do carcinoma avançado de células escamosas da pele, do carcinoma de células escamosas do colo uterino, e em cânceres de cabeça e pescoço (GUDAS, 1992; HONG e ITRI, 1994; LIPPMAN et al., 1995; LOTAN, 1996; HONG e SPORN, 1997).

Da mesma forma, em estudo recente conduzido em 89 pacientes que foram seguidos por um periodo aproximado de 38 meses, descreveu-se que a administração por via oral de um retinóide acíclico, o ácido poliprenóico, foi capaz de reduzir significantemente a incidência de novos carcinomas hepatocelulares, após injeção percutânea com etanol ou ressecção cirúrgica do câncer primário (MUTO et al., 1996).

\subsubsection{Estudos in vitro e em Animais de Experimentação}

A base racional para a utilizaçăo de retinóides como agentes quimiopreventivos ou na terapia do câncer começou a ser estabelecida há praticamente oito décadas, quando se observou que a deficiência de vitamina A poderia resultar em metaplasias nos epitélios dos 
tratos respiratório, gastrointestinal e urinário (MORI, 1922; WOLBACH e HOWE, 1925), bem como no desenvolvimento de carcinomas de estômago em ratos (FUJIMAKE, 1926).

Entretanto, não foi senão mais recentemente, inclusive com a descuberta da ação anticarcinogênica da vitamina A (SAFFICiTI et al., 1967), que houve grande impulso na pesquisa dessa área do conhecimento (WOLF, 1996).

Estudos in vifro demonstraram, principalmente a partir dos anos 1970s, que retinóides podem reverter alteraçōes pré-malignas dos epitélios de traquéia de "hamster" e de glândulas da próstata ou mamárias de camundongo em culturas de órgão, bem como suprimir a tansformação maligna de inúmeras linhagens de células, induzida por carcinogênicos virais, físicos ou quimicos (MOON ef al., 1994; LOTAN, 1996).

Da mesma forma, inúmeros estudos avaliaram nos últimos anos a ação quimiopreventiva ou terapêutica dos retinóides, em vários modelos de carcinogênese que utilizavam animais de experimentaçåo. Logo de inicio empregou-se mais frequentemente refinóides de ocorrência natural, tais como o retinol e os ácidos retinóicos todo-trans e 13-cis. Todavia, com o aumento da disponibilidade de retinoides sintéficos, vêm sendo testados compostos mais ativos e que apresentam, inclusive, menos toxicidade.

Assim, em modelo de carcinogênese mamária induzida pela administração de DMBA observou-se, por exemplo, ainda em 1976, uma redução de $52 \%$ na incidència de cânceres de ratos tratados diariamente com acetato de retinila, em comparação a animais que receberam somente placebo em suas rações (MOON et al., 1976). Estudos subsequentes não apenas confirmaram esses resultados, como também demonstraram uma ação inibitória da vitamina $A$ no modelo de carcinogênese mamária induzida pela aplicação de MNU. Observou-se ainda que a vitamina A foi também capaz de prevenir a ocorrência de novas neoplasias mamárias, após remoção cirúrgica do câncer primário (MOON e MEHTA, 1990).

Mais recentemente, demonstrou-se que o ácido retinóico 9-cis apresentou maior efeito inibitório do que o isômero todo-trans, em modelo de carcinogênese mamária induzida pela MNU em ratos, sendo particularmente efetivo se combinado com o tamoxifeno ou raloxifeno, moduladores seletivos de receptores para estrógenos (ANZANO et al., 1994; 1996; HONG e SPORN, 1997).

De uma forma geral, tais estudos indicaram que durante o processo de carcinogênese mamária existe um periodo ideal em que as células respondem ao tratamento com os retinóides, e de que estes são mais eficazes se administrados de forma continua, principalmente durante as etapas de promoção e progressão (MOON et al., 1994; LOTAN, 1996).

Descreveu-se ainda que a administração de vitamina $A$, bem como dos ácidos retinóicos todo-trans e 13-cis, principalmente durante a etapa de promoção, foi também capaz de inibir a formação de papilomas cutâneos em modelo de carcinogênese de pele induzida pelo DMBA em camundongos, com ou sem a aplicaçäo concomitante de um agente promotor como o éster de forbol ou a antalina, antrona ou o ácido ocadáico (DAVES, 1967; DAWSON, 1987; LOTAN, 1996; DE LUCA et al., 1997).

Resultados conflitantes foram, entretanto, descritos em relação aos efeitos de retinóides na fotocarcinogênese, em que papilomas e carcinomas da pele são induzidos pela radiação UV-B. Na verdade, diversos estudos nos anos 1970 s e 1980 s observaram nesse modelo, aumento da carcinogênese quando o ácido retinóico foi aplicado topicamente ou administrado por via oral (MOON et al., 1994; LOTAN, 1996). Todavia, em estudo mais recente observou-se nesse tipo de modelo em camundongos, supressāo da conversāo de papilomas em carcinomas pela aplicação tópica de ácido refinóico todo-trans (ATHAR et al., 1991).

Demonstrou-se também que o ácido retinóico 13-cis foi capaz de inibir a carcinogênese oral em tês diferentes modelos experimentais, ou seja, as carcinogêneses induzidas na bolsa 
facial e na lingua de "hamsters" pela aplicação de DMBA, e a induzida na cavidade oral de camundongos pela administração de óxido de nitroquinolina (LOTAN, 1996).

Além disso, observou-se que os ácidos retinóicos todo-trans e 13-cis, bem como diversas retinamidas, incluindo a $4 \mathrm{HPR}$, além de suprimirem a atipia histológica de lesões uroteliais, também reduziram a incidência, o número e a severidade de carcinomas de bexiga induzidos pela administração intragástrica de $\mathrm{N}$-butili- $\mathrm{N}$-(hidroxibutil) nitrosamina em ratos ou camundongos. $\mathrm{A}$ maioria dos retinóides efetivos reduziu o aparecimento das neoplasias, suprimindo a progressāo de lesões uroteliais a carcinomas de rápido crescimento (MOON et al., 1994; LOTAN, 1996).

Relatou-se, ainda, que o acetato de retinila foi capaz de inibir a carcinogênese vesical induzida pela suplementação de rações de camundongos com o carcinogênico $\mathrm{N}$-[4-(5-nitro-2-furil)-2-tiazolinformamida, e de reduzir a incidência de adenomas e carcinomas pancreáticos em ratos tratados com rações suplementadas com azasserina, ou o número de adenomas presentes no cólon de ratos expostos à DMH (MOON et al., 1994; LOTAN, 1996).

Descreveu-se também ainda recentemente, que o ácido retinóico 9-cis e a 4-HPR reduziram a proliferaçāo celular e preveniram a formaçāo de lesōes pré-neoplásicas e de cânceres, em ratos tratados com azoximetano como carcinogênico indutor da carcinogênese de cólon (ZHENG et al., 1997).

\subsection{Retinóides e Hepatocarcinogênese Experimental}

Quanto aos poucos estudos descritos na literatura a respeito dos efeitos de refinóides na hepatocarcinogênese, seus resultados têm sido também muitas vezes conflitantes.

Investigações conduzidas nos anos 1970 s em ratos submetidos a modelo que empregava aflatoxina B1 como hepatocarcinogênico, demonstaram, inicialmente, que tanto a administraçāo de palmitato de retinila como a de acetato de retinila não foram capazes de inibir o desenvolvimento de cânceres hepáticos (NEWBERNE e ROGERS, 1973b; NEWBERNE e SUPHAKARN, 197 ).

Mais recentemente demonstrou-se, entretanto, que ratos expostos a diferentes doses do hepatocarcinogênico $3^{\prime}-M D A B$ na ração e tratados com rações suplementadas com acetato de retinila (1 $\mathrm{mmol} / \mathrm{kg}$ ), não apresentaram nódulos hepáticos observáveis, ao contrário dos animais do grupo controle, cujos figados foram bastante comprometidos por essas lesões préneoplásicas (MACK el al., 1990).

Por outro lado, relatou-se, a seguir, que a administração intraperitoneal intermitente de retinol em diferentes dosagens $(6,25 ; 12,5$ e 25 mg/rato) durante as etapas iniciais da hepatocarcinogênese induzida pelo carcinogênico $3^{\prime}-\mathrm{MDAB}$ resultou em aumento moderado, mas não significante, no desenvolvimento de cânceres hepáticos em ratos (OHKAWA ef al., 1991).

Em camundongos $\mathrm{C}_{3} \mathrm{H}-\mathrm{A}$ vy femeas tratados com rações suplernentadas com acetato de retinila observou-se, por sua vez, redução dose-dependente na incidência de hepatomas espontáneos (MAIORANA e GULLINO, 1980), ao contrário de camundongos submetidos a modelo de hepatocarcinogênese induzida pela aplicação de DEN e tatados com ácido retinóico todo-trans ou retinamidas, que apresentaram aumento no número de carcinomas hepatocelulares (MCCORMICK of al., 1990).

Em contraste, constatou-se ao final de um outo estudo que $90 \%$ dos ratos alimentados com rações contendo o carcinogênico 3'-MDAB desenvolveram cânceres hepáticos, enquanto isto ocorreu em apenas $11 \%$ dos animais que receberam a mesma ração suplementada com 0 ácido retinóico 13-cis (DAOUD e GRIFFIN, 1980). 
Da mesma forma, descreveu-se que injeções intramusculares de ácido retinóico todo-trans em ratos tratados com o carcinogênico $\mathrm{N}$-nitrosomorfolina dissolvido na água dos bebedouros, resultaram em reduçôes significantes no número, e dirnensões de lesões pré-neoplásicas positivas para a enzima $\gamma \mathrm{GT}$, com concomitante aumento no número de lesões myc 110-negativas, sugerindo um efeito supressor desse retinóide na expressão do oncogene myc e na proliferação celular de lesões pré-neoplásicas hepáticas (BABA et al., 1991).

Os resultados desse estudo estão de acordo com outra observação também conduzida em ratos, em que a suplementação das raçōes com palmitato de retinila foi capaz de reduzir o número e volume de lesões pré-neoplásicas induzidas nos animais por aplicação de dois diferentes agentes promotores durante 8 semanas consecutivas, em modelo de hepatocarcinogênese que utilizava DEN como agente iniciante (BERBERIAN et al., 1995).

Em contrapartida, observou-se em nosso meio que ratos submetidos ao modelo do hepatúcito resistente $(\mathrm{RH})$, que também utiliza a DEN como carcinogênico iniciante mas que não emprega agente promotor por tempo prolongado, e tratados concomitantemente com acetato de retinila por oito semanas consecutivas durante as fases de iniciaçãolseleção, apresentaram uma incidência de nódulos hepáticos de $100 \%$ e apenas uma diminuição moderada do número total dessas lesões pré neoplásicas, em comparação a animais do grupo controle. Nessas condiçōes experimentais, a administraçäo de vitamina $A$ também não reduziu significantemente o número e as dimensões de focos de hepátocitos marcados positivamente pela enzima rGT (MORENO et al., 1995a).

Além disso, descreveu-se posteriormente ainda em nosso meio, que ratos submetídos ao modelo de hepatocarcinogênese do $\mathrm{RH}$ e tratados com acetato de retinila por cinco semanas consecutivas durante a fase de promoção inicial da carcinogênese, também não apresentaram reduçōes significantes nos números e dimensōes das lesōes pré-neoplásicas hepáticas, em comparação a animais do grupo controle (RIZZ) et al., 1997).

Quando administrada especiricamente por oito semanas durante a fase de progressão observou-se recentemente, entretanto, que a vitamina $A$ foi capaz de reduzi a incidência de hepatocarcinomas e nódulos persistentes de hepatócitos em ratos Wistar submetidos ao modelo do $\mathrm{RH}$ (SILVEIRA, 1998).

\subsubsection{Mecanismos de Ação dos Retinóides Envolvidos com a Carcinogênese}

Até o presente foram aventados inúmeros mecanismos que poderiam estar relacionados com as ações da vitamina $A$ e dos retinóides nas etapas da iniciação, promoção e progressão da carcinogènese (GUDAS et al., 1994).

Assim, demonstrou-se que a vitamina $A$ e outros refinóides podem inibir mutagênicos de ação direta, bem como a ativação metabólica de alguns carcinógenos químicos, que de outra forma interagiriam com o DNA lesando-o (LUPULESCU, 1993). Relatou-se, ainda, que os retinoides poderiam também induzir as afividades de enzimas relacionadas com a metabolização de compostos químicos (GUDAS et al., 1994; WANG e HIGUCHI, 1995).

Estes efeitos poderiam ser, portanto, responsáveis pela atividade anticarcinogênica dos retinoides mais especificamente na fase de iniciação, embora se tenha descrito que estes compostos agem preferencialmente nas etapas mais tardias da carcinogênese, ou seja, na promoçāo e progressão (LUPULESCU, 1993; LOTAN, 1996).

A etapa de promoçāo envolve a expansão da população de células iniciadas para formar uma lesão pré-neoplásica, com subsequente progressão e conversão da mesma em uma neoplasia maligna. Estes processos estão associados, basicamente, com desregulação da 
proliferação celular e diferenciação aberrante, bem como com perda da capacidade ou tendência diminuida das células sofrerem apoptose (LOTAN, 1996).

Desta forma, as evidências de que os retinóides podem também atuar de modo protetor na etapa da promoção ou progressão da carcinogênese se devem, basicameiıte, a diversas investigaçōes que demonstraram as capacidades dessas substâncias de inibir a transformação in vitro de diversas linhagens celulares, de reverter lesões pré-neoplásicas em animais, e de suprimir a síntese do DNA, a prokiferação celular e a angiogênese, além de induzir a diferenciação e a apoptose de células. Além disso, retinóides podem ainda alterar comunicações intercelulares do tipo hiato, inibir a produção de prostaglandinas, a indução da enzima ornitina descarboxilase ou a expressão de oncogenes como c-fos ou c-myc e fatores de crescimento do tipo TGF- $\alpha$, bem como estimular a expressão de citocinas tais como o TGF- $\beta$, inibindo assim a carcinogênese (GUDAS et al., 1994; LOTAN, 1996).

Quanto ao papel das prostaglandinas na carcinogênese, descreve-se que estas teriam potencialmente importância nas fases pós-iniciação, devido a seus papéis na modulação da vigilância imunitária (MARNET, 1992) e pelo fato da hiperexpressão da enzima cicloxigenase-2, que cataliza a sintese de prostaglandinas e a produção de radicais eletrofilicos mutagênicos, estar relacionada com uma inibiçāo da apoptose em células epiteliais (TSUJII e DUBOIS, 1995). Portanto, inibidores dessa enzima teriam, teoricamente, um efeito anticarcinogênico, o que foi confirmado através da utilizaçảo de antinfiamatórios não-esteroidais em modelos experimentais in vivo de carcinogênese de cólon, bem como em seres humanos (MARNETT, 1992; GIARDELLO et al., 1993; HONG e SPORN, 1997).

Relatou-se ainda recentemente que retinóides tais como o acetato de refinila e o ácido retinóico, podem suprimir a indução da enzima cicloxigenase-2 e a produção de prostaglandína $E_{2}$, mediadas pelo agente promotor éster de forbol em células epiteliais da cavidade oral, sugerindo que estes efeitos poderiam estar também relacionados com suas atividades quimiopreventivas contra o câncer (MESTRE et al., 1997).

Já a enzima ornitina descarboxilase, que cataliza a descarboxilação da ornitina em putrescina, desempenha importante papel na síntese de poliaminas e, portanto, na proliferação celular, podendo ser induzida por diversos fatores, incluindo a administraçäo de agentes promotores do câncer. Nesse sentido, descreveu-se que refinóides podem reduzir sua atividade em diversas linhagens celulares e em modelos experimentais in vivo, 0 que também explicaria, ao menos em parte, os efeitos inibitórios desses compostos na etapa de promoção da carcinogênese (GUDAS et al., 1994).

Entretanto, acredita-se hoje em dia que é, na verdade, a capacidade que os retinóides têm de modular a expressão gênica através de suas interaçōes com receptores nucleares que atuam como fatores de transcrição, a principal responsável por suas propriedades biológicas e atividades na carcinogênese.

Assim, existem inúmeras evidências de que atteraçōes na estrutura, função e expressão dos próprios genes desses receptores nucleares para retinóides estão associadas com a carcinogênese.

Nesse sentido, demonstrou-se, por exemplo, há já alguns anos, a existência de alteraçāo no gene para o receptor RAR $\alpha$ na leucemia promielocitica aguda, com a ocorrência de uma translocaçāo cromossômica t(15;17) fundindo o gene PML do cromossomo 15 com o gene para o receptor RAR a localizado no cromossomo 17 (WARRELL et al., 1993; SILVEIRA e MORENO, 1998) e, em um caso de carcinoma hepatocelular humano, alteração do gene para o receptor RARß por integração do DNA do virus da hepatite $B$ (DEJEAN et al., 1986).

Da mesma forma, demonstrou-se também uma redução nas expressöes dos genes para os receptores RAR $\alpha$ e RARY na pele normal e em neoplasias cutâneas benignas de camundongos, induzida pela administração do agente promotor éster de fortol. Esta se associava, no caso, com uma 
ativaçāo concomitante do oncogene v-ras ${ }^{\text {th }}$ e maior risco de conversão à malignidade (DARWICHE et al., 1996). \}. Já a introdução de um vetor recombinante de expressão do receptor RAR $\alpha$ em células de papiloma cutâneo resultou em inibição da proliferaçăo celular, em resposta à administração de ácido retinóico (DARWICHE et al, 1996; DE LUCA ef al., 1997).

Observou-se, ainda, concentações reduzidas ou praticamente não-detectáveis do mRNA para o receptor $R A R \beta$ em muitas linhagens celulares epiteliais malignas derivadas, por exemplo, de carcinomas de pulmão (ZHANG ot al., 1994; 1996), de câncer epitelial ovariano (CALARO ef al, 1994), de carcinomas do colo uterino (GEISEN et al., 1997), de carcinomas de células escamosas da orofaringe (HU et al., 1991) e de cânceres de mama (SWISSHELM et al, 1994; ZHANG et al., 1996), bem como redução do mRNA para RARß em carcinoma de células escamosas da região da cabeça e pescoço (XU et al., 1994), em lesões pré-neoplásicas da cavidade oral (LOTAN et al, 1995b) e em carcinomas de mama (XU et al., 1997).

Redução de transcritos para o receptor RARß foi também constatada em linhagens de células de hepatoma, em comparação ao figado adulto de rato. Isto sugere que o aumento da expressão para RARß esteja associado, no caso, à diferenciação ou maturação dos hepatócitos (WAN ef al., 1992).

Por outro lado, essas diversas observaçōes sugerem, ainda, de uma forma geral que uma reduçāo ou perda específica da expressāo de determinado gene codficante para receptor nuclear de refinóide, como por exemplo do gene para o receptor RAR $\beta$, possa constituir evento importante no processo em múltiplas etapas da carcinogênese e contribuir para com a resistência a refinóides observada em certas células, e que estes poderiam representar, inclusive, anti-oncogenes (GERADTS et al., 1993; ZHANG et al., 1996; DE LUCA et al., 1997; XU et al., 1997).

As observaçōes de que a transfecção de células de carcinoma epidermóide de pulmāo humano com um plasmidio de expressăo do receptor RARß resultou em reduçāo da carcinogenicidade em camundongos (HOULE et al, 1993), e de que camundongos transgênicos que expressam um gene RAR $\beta$ anti-sentido desemolveram cânceres pulmonares (BERARD et al., 1996), bem como a constatação de que a transfecção de células de câncer de mama hormônio independente com o gene RARß resultou em recuperação da sensibilidade a retinóides por parte dessas células previamente deficientes nesse gene (ZHANG et al., 1996), reforçam esta hipótese.

Além disso, que alteraçōes na expressão do gene RAR $\beta$ podem ainda contribuir para o desenvolvimento de cânceres do colo uterino, foi também sugerido pela análise de hibridos formados ente células somáticas Hela de carcinoma de colo uterino e células humanas normais. Assim, demonstrou-se que o tatamento com ácido refinóico resulta em potente induçāo na expressão do gene RARß em hibridos não-carcinogênicos ente células HeLa e células normais, mas não nas células HeLa parentais ou nos hibridos carcinogênicos (BAUST et al., 1996).

De certo modo em concordância com essas observações relatou-se, ainda, que a hiperexpressão de RARß em células HeLa resultou em dramática supressão da proliferação celular na presença de ácido refinóico todo-trans, mas não em sua ausência (FRANGIONI et al., 1994).

Assim, a ativação transcricional mediada pelos receptores nucleares e induzida pelos retinóides pode contribuir para com a atividade anticarcinogênica descrita para diversas dessas substâncias naturais e sintéticas.

Um exemplo já bem conhecido é a ativação do receptor RAR $\alpha$ pela administração de ácido retinóico todo-trans ou 9-cis como terapia de diferenciaçāo na leucemia promielocitica aguda, com consequente maturação dos promielócitos leucêmicos não-diferenciados e proliferantes, em granulócitos diferenciados não-proliferantes que são, então, eliminados por apoptose (WARRELL et al., 1993; CHOMIENNE et al, 1996).

Descreveu-se ainda que o receptor RAR $\beta$ ativado por seus respectivos ligantes pode ser necessário à atividade anticarcinogênica de análogos da vitamina A em pacientes portadores de 
lesões orais (LOTAN of al., 1995), ou em células de câncer de mama, talvez também mediada, neste caso especifico, por uma indução de apoptose (LIU et al., 1996).

Por outro lado, a atividade anticarcinogènica dos retinóides pode estar também relacionada à capacidade que alguns destes compostos têm de transreprimir o complexo protéico AP-1, cuja desregulação está associada a estados inflamatórios e à transformação maligna.

Sugeriu-se portanto recentemente que retinóides que têm a capacidade de transreprimir especificamente AP-1, inibindo desta forma os processos de proliferação e transformação das células, poderiam representar valjosos agentes terapêuticos antiproliferativos e contra o câncer, produzindo, inclusive, menos efeitos colaterais (FISHER e VOORHEES, 1996; AGADIR et al., 1997).

Nesse sentido, descreveu-se também nos últimos anos que refinóides com atividade específica anti-AP-1 foram capazes de inibir a proliferação de linhagens de células epiteliais da epiderme de camundongo sensiveis à transformação por agente promotor, e de cânceres de pulmão e de mama (FANJUL et al, 1994; CHEN et al., 1995; Ll et al., 1996). 


\section{OBJEMVOS}

\subsection{Geral}

Avaliar e comparar os efeitos das administrações de $\beta$-caroteno e vitamina $A$ em ratos Wistar na etapa de progressão do modelo de hepatocarcinogênese do "hepatócito resistente".

\subsection{Específicos}

- Avaliar em ratos Wistar a ocorrência ou nāo de eventuais efeitos inibitórios do $\beta$-caroteno e da vitamina A em lesỏes pré-neoplásicas e neoplásicas, quando administrados durante a etapa de progressão do modelo de hepatocarcinogênese do "hepatócito resistente".

- Avaliar em ratos Wistar a ocorrência ou não de eventuais efeitos modulatórios do $\beta$-caroteno ou da vitamina $A$ na proliferaçāo celular, quando administrados durante a etapa de progressão do modelo de hepatocarcinogênese do "hepatócito resistente".

- Avaliar em ratos Wistar a ocorrência ou não de eventuais efeitos modulatórios do $\beta$-caroteno ou da vitamina A na metilaçāo dos proto-oncogenes c-Ha-ras e c-myc, bem como do gene que codifica para a enzima HMGCoA redutase, quando administrados durante a etapa de progressāo do modelo de hepatocarcinogênese do thepatócito resistente". 


\section{MATERIAL E MÉTODOS}

\subsection{Animais}

Foram utilizados neste estudo ratos machos da linhagem Wistar (Ratus norvegicus, var. albinos, Rodentia mammalia), com peso médio inicial de $50,1 \pm 1,9 \mathrm{~g}$, e obtidos a partir de colônia do biotério da Faculdade de Ciências Farmacêuticas da Universidade de São Paulo. Estes foram mantidos durante todo o experimento em sala desse mesmo biotério provida de ar condicionado, e que propiciava a manutenção de uma temperatura ambiente de $22^{\circ} \mathrm{C} \pm 2{ }^{\circ} \mathrm{C}$, bem como de sistema de iluminaçäo programado para geração de cictos claro-escuro de 12 horas cada, com luz acesa a partir das 6 horas.

Nesse ambiente controlado, os animais foram alojados em número de no máximo quatro, em gaiolas de polipropileno com tampas de aço inoxidável e contendo maravalha previamente esterilizada, que foi trocada rotineiramente em dias alternados. Estes receberam, ad libitum, e durante todo o estudo, água e ração comercial peletizada (Purina Nutrimentos Ltda., Campinas, Brasil), sendo ainda controlado o peso dos ratos em dias alternados.

\subsection{Delineamento experimental}

Após um periodo de aclimatação de 4 dias, com exceção de quatro animais que constituíram um grupo controle nảo submetido a qualquer procedimento experimental durante todo o estudo (ratos normais), mas que simplesmente permaneceram na mesma dependência do biotério em que os outros grupos experimentais foram alojados até serem sacrificados após 12 meses, todos os outros ratos $(n=28)$, foram submetidos ao modelo de hepatocarcinogênese do "hepatócito resistente" (RH) desenvolvido por SOLT e FARBER (1976), modificado por SEMPLE-ROBERTS et al. (1987) e adaptado para ratos Wistar (MORENO et al., 1991).

Para tanto, administrou-se nos animais, logo de inicio, e por via intraperitoneal, uma única dose (20 mg/100 g de peso corpóreo) necrogênica de dietilnitrosamina (DEN - Sigma Chemical Co., St Louis, MO, USA), dissolvida em solução salina estéril a 0,9\%. Decorridas duas semanas, deuse início ao processo de seleção/promoção com a aplicação intragástrica, em dose única diária ( $2 \mathrm{mg} / 100 \mathrm{~g}$ de peso corpóreo), por quatro dias consecutivos, de 2-acetilaminofluoreno (2-AAF - Sigma) dissolvido em dimetilsulfóxido (DMSO - Sigma) e óleo de milho (Mazola ${ }^{\circledR}$ ).

A seguir, 24 horas após a quarta dose de 2-AAF, todos os ratos foram submetidos a uma hepatectomia parcial a 70\%, basicamente de acordo com HIGGINS e ANDERSON (1931), e no $2^{\circ}$ e $4^{\circ}$ dias após a cirurgia, administrou-se ainda nos mesmos, por via intragástrica, doses únicas de 2-AAF (20 mg/kg de peso corpóreo), também dissolvidas em dimefilsulfóxido e óleo de milho (Figura 1).

Após esse procedimento, os animais foram distribuidos, quando indicado, em tếs diferentes grupos experimentais, ou seja, nos grupos denominados OM, $\beta C$ e VA, respectivamente.

Decorridos 10 meses da iniciação com DEN, deu-se inicio ao tratamento dos três grupos de ratos, com óleo de milho (grupo OM; $0,25 \mathrm{~mL} / 100 \mathrm{~g}$ de peso corpóreo), $\beta$-caroteno (grupo $\beta C ; 7 \mathrm{mg} / 100 \mathrm{~g}$ de peso corpóreo dissolvidos em 0,25 mL de óleo de milho; trans $\beta$-caroteno tpo 1, Sigma) ou vitamina A (grupo VA; $1 \mathrm{mg} / 100 \mathrm{~g}$ de peso corpóreo dissolvido em 0,25 $\mathrm{mL}$ de oleo de milho; acetato de retinila, Merck, RJ, Brasil), respectivamente, por via intragástrica e em dias alternados, e que se estendeu por 8 semanas consecutivas até a ocasião do sacrificio dos animais (Figura 1). 
EFEITOS DAS ADMINVISTRAÇCEES DE $\beta$-CAROTENOE VITAMINA A EM RATOS WISTAR NA ETAPA DE PROGRESSÃO DO MODELO DE HEPATOCARCINOGENESE DO "HEPATOCOTO RESISTENTE'

FIGURA 1. Representação esquemática do modelo experimental.

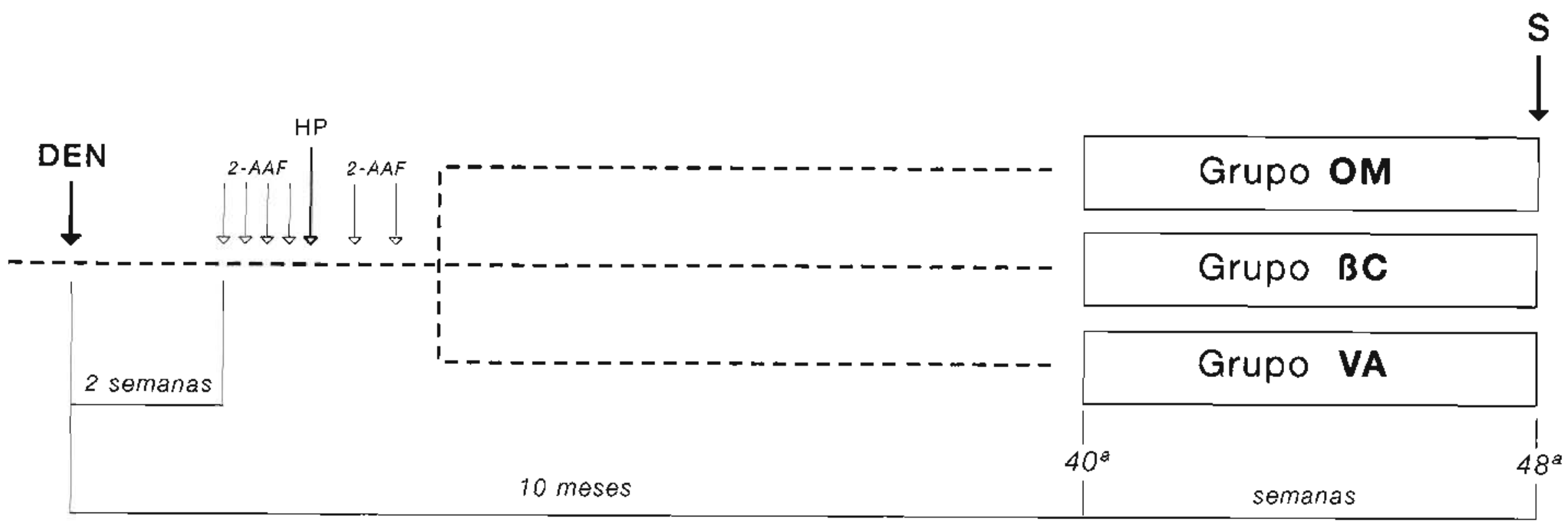

DEN - Dietilnitrosamina (20 $\mathrm{mg} / 100 \mathrm{~g}$ de peso corpóreo)

2-AAF - 2-Acetilaminofluoreno (6 $\times 2 \mathrm{mg} / 100 \mathrm{~g}$ de peso corpóreo)

HP - Hepatectomia parcial $(70 \%)$

OM - Óleo de milho $(0,25 \mathrm{~mL} / 100 \mathrm{~g}$ de peso corpóreo $)$

BC - B-Caroteno ( $7 \mathrm{mg} / 100 \mathrm{~g}$ de peso corpóreo)

$\mathrm{VA}$ - Vitamina A ( $\mathrm{mg} / 100 \mathrm{~g}$ de peso corpóreo)

$S$ - Sacrificio 


\subsection{Veriflcação da Pureza do $\beta$-caroteno e da Vitamina A a Serem Administrados nos} Animais

Para cálculo das quantidades adequadas de $\beta$-caroteno e vitamina $A$ a serem administradas nos animais em dias alternados e por 8 semanas consecutivas, verificou-se a pureza dessas substâncias após preparo de uma solução-mãe de concentração teoricamente connecida, do carotenóide (trans $\beta$-caroteno tipo 1, Sigma) em éter de petróleo (Synth PA) e da vitamina A (acetato de retinila, Merck) em hexano (Merck PA). Devido à alta concentração dessas soluçōes, estas foram a seguir diluidas, procurando-se obter as concentraçōes adequadas para leituras a serem realizadas em espectrofotômetro (Beckman, modelo DU-70, CA, EUA).

De posse dos valores de absorbâncias máximas, calculou-se o teor real de $\beta$-caroteno e retinol (vitamina A) nas respectivas soluçōes, utilizando-se a seguinte fórmula:

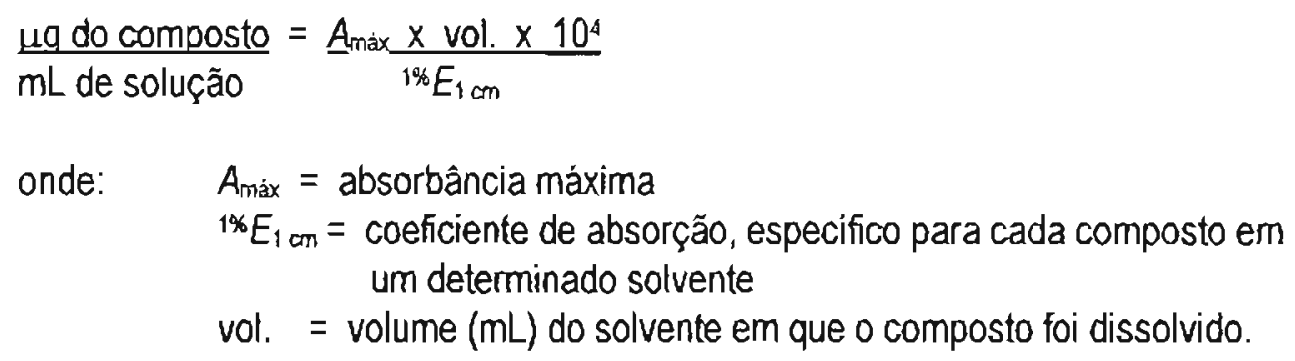

O valor do coeficiente de absorção utilizado para o cálculo do $\beta$-caroteno foi de 2592 , referente ao éter de petróleo (DAVIES, 1976), realizando-se a varredura entre 350 e 520 nm no espectrofotômetro.

Da mesma forma, o valor do coeficiente de absorção empregado para o cálculo do retinol foi de 1826, referente ao hexano (RETTENMAIER e SCHUEP, 1992), sendo a varredura realizada entre 300 e $350 \mathrm{~nm}$.

Determinou-se a porcentagem de pureza relacionando-se os valores real e teórico.

\subsection{Sacrifício dos Animais}

Decorridas as 8 semanas de tratamento dos três grupos experimentais, na noite anterior ao sacrificio retirou-se as rações que estavam à disposição dos ratos.

Uma hora antes deste ocorrer administrou-se, entretanto, em todos os animais, uma única dose intraperitoneal (10 mg/100 de peso compóreo) de 5-bromo,2-desoxiundina (BrDU - Sigma), dissolvida em DMSO (Sigma) e solução sadina (1:3 v/v).

Além disso, antes do sacrificio pesou-se todos os ratos em balança eletônica digital (ACATEC BCM 1100; São Paulo, Brasil). A seguir, estes foram anestesiados com éter etúlico (Merck PA) e colocados em decúbito dorsal sobre prancha cirúrgica, procedendo-se, entāo, à laparotomia.

O sacrificio se deu sob inalação continua do anestésico, através de secção da aorta abdominal e consequente choque hipovolêmico.

Em seguida, retirou-se o figado dos ratos, que foi entāo "lavado" em solução salina à $0,9 \%$ gelada, pesado em balança eletrônica digital ACATEC BCM 1100 e examinado do ponto de vista macroscópico. 
Subsequentemente, seccionou-se cada lobo hepático em fatias de aproximadamente $0,3 \mathrm{~cm}$ de espessura compreendendo, concomitantemente, regiões ao redor das lesōes consideradas "normais" à macroscopia e as próprias lesões pré-neoplásicas e neoplásicas, para posterior fixaçāo e realização de exames microscópicos (histoquímica enzimática pâía a yGT, histopatológico atavés da hematoxilina-eosina e imunohistoquímica para a BrDU\}.

Colheu-se na ocasião amostras do lobo direito do figado contendo apenas as regiōes consideradas "normais" à macroscopia para determinação das concentrações hepáticas de $\beta$-caroteno, retinol e DNA, bem como para a avaliação da metilação dos proto-oncogenes c-Haras e c-myc e do gene que codifica para a enzima HMGCoA redutase. Da mesma forma, colheu-se também amostras de lesões hepáticas pré-neoplásicas e neoplásicas eventualmente presentes, especificamente para avaliação da mefilação dos proto-oncogenes c-Ha-ras e c-myc, bem como do gene para a enzima HMGCoA redutase. Estas foram imediatamente congeladas em nitrogênio liquido e, a seguir, armazenadas em congelador a $-70^{\circ} \mathrm{C}$ (Kelvinator series 100 , Wis., EUA).

\subsection{Exame Macroscópico}

Cada lobo do figado foi examinado individualmente, logo de início, quanto à presença em sua superficie de formaçōes pré-neoplásicas (Figuras 2a, b e c) ou neoplásicas (Figuras 3a e b) de tamanhos variados e coloração em geral esbranquiçada ou amarelada, que se distinguiam do parênquima hepático.

Após o exame da superficie, cada lobo hepático foi seccionado em fatias de aproximadamente $0,3 \mathrm{~cm}$ de espessura, sendo, então, também identificadas e contadas as lesões internas. 
FIGURA 2. Aspecto macroscópico de figado de rato tratado com óleo de milho (a), $\beta$-caroteno (b) ou vitamina $A$ (c) por oito semanas consecutivas durante a fase de progressão do modelo de hepatocarcinogênese do "hepatócito resistente". Observar a presença de formações nodulares (seta) na superficie, de cor amarelada e com contornos bem definidos. 

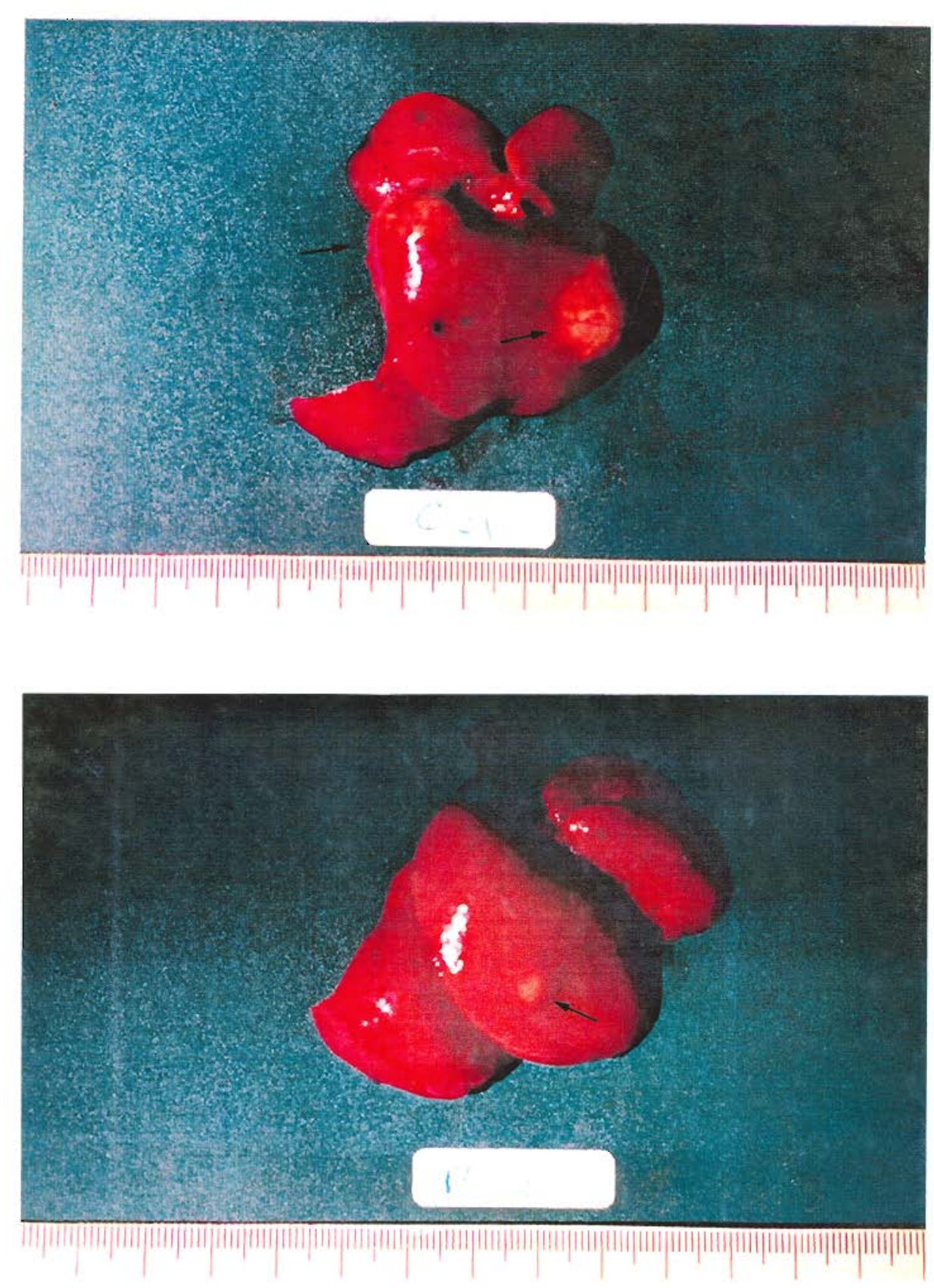

b

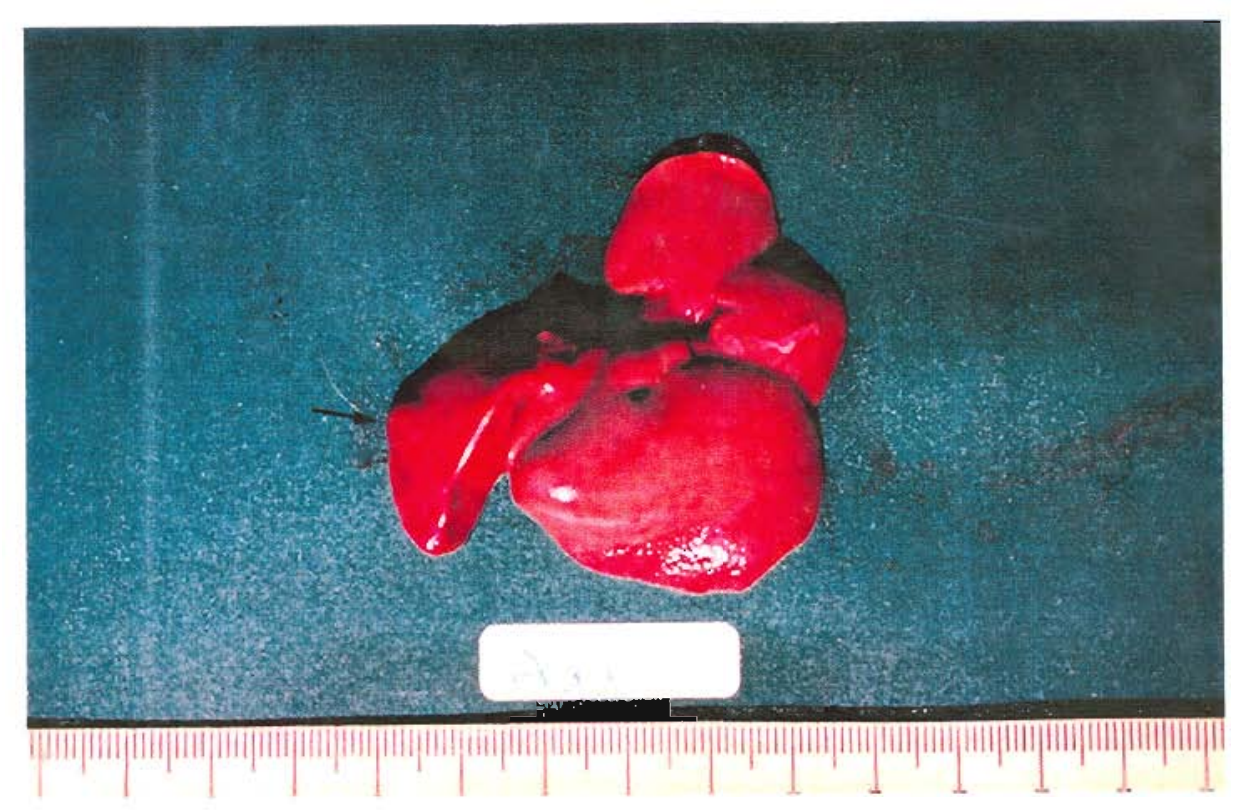

C 
Figura 3 a e b. Aspecto macroscópico de figado de rato tratado com óleo de milho por oíto semanas consecutivas durante a fase de progressão do modelo de hepatocarcinogenese do "hepatócito resistente". Observar na superficie dos diversos lobos hepáticos, a presença de formações nodulares de coloração amarelada ou esbranquiçada, com volumes desiguais e contornos irregulares e mal delimitados, comprometendo e deformando grosseiramente o órgão. 
EFEITOS DAS̈ ADMINISTRACCOES DE ß-CAROIENO E VITAIMINAA A EM RATOS WISTAR NA ETAPA DE PROGRESSĀO
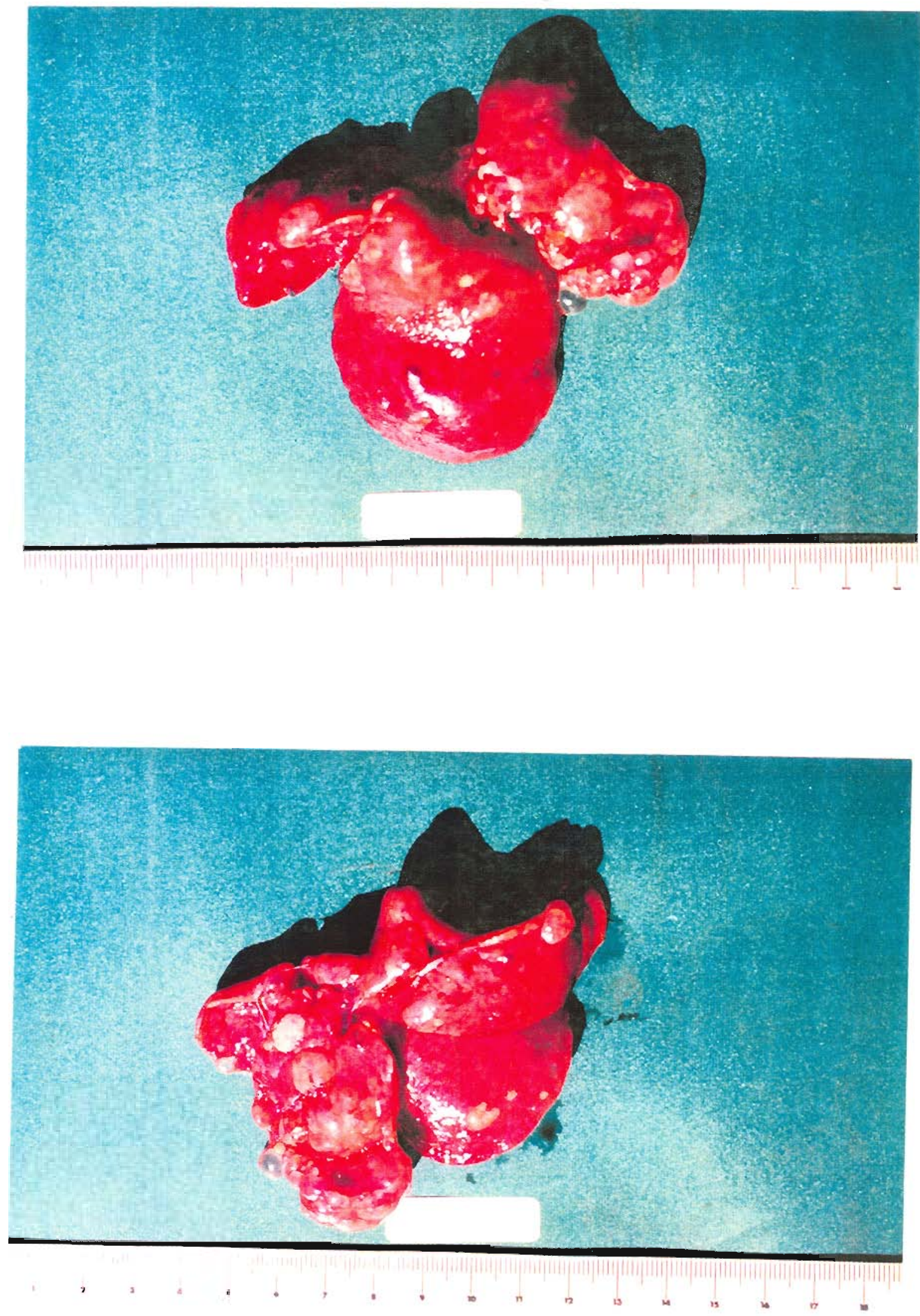

b 


\subsection{Exame Microscópico}

\subsubsection{Microscopia de Luz}

Por ocasiāo do sacrificio dos animais foram colhidos fragmentos representativos de cada lobo hepático, de aproximadamente $5 \mathrm{~mm}$ de espessura, e submetidos aos seguintes procedimentos:

\subsubsection{Histoquímica Enzimática para Evidenciação da Atividade de $\gamma$-glutamiltranspeptidase $(\gamma \mathrm{GT})$}

Os fragmentos de figado foram rapidamente congelados em nitrogênio liquido e transportados em gelo seco, para subsequente estocagem em congelador a $-70^{\circ} \mathrm{C}$.

Posteriomente, utilizou-se um criostato Cryocut 1800 (Reichert-Jung; Alemanha), do Laboratório de Oncologia Experimental do Departamento de Patologia da Faculdade de Medicina Veterinária e Zootecnia da Universidade de Sāo Paulo, São Paulo, para obtenção de cortes de 10 micrômetros. A seguir, estes foram fixados em acetona (Synth PA) a $4{ }^{\circ} \mathrm{C}$ por 10 minutos e mantidos em geladeira até a realização da reação de coloração.

Nesse sentido, a técnica utilizada foi a preconizada por RUTENBURG et al. (1969). Para tanto, realizou-se, inicialmente, incubação dos cortes em estufa a $37^{\circ} \mathrm{C}$, por 30 minutos, com a seguinte mistura:

- 2,5 mg de $y$-glutamil-4-metoxi-2-naftilamida (Sigma), dissolvidos em 0,05 mL de DMSO (Sigma);

- $\quad 0,05 \mathrm{~mL}$ de hidróxido de sódio $1 \mathrm{~N}$ (Merck PA);

- $14 \mathrm{~mL}$ de cloreto de sódio a 0,85\% (J. T. Backer PA, SP, Brasil);

- $10 \mathrm{~mL}$ de glicil-glicina (Sigma), e

- $10 \mathrm{mg}$ de Fast Blue BB salt (Sigma).

A seguir, após a incubação, lavou-se os cortes por 2 minutos em solução salina à $0,9 \%$, em solução de sulfato de cobre 0,1 M (J. T. Backer PA) por 2 minutos e, novamente, em solução salina a $0,9 \%$ por 2 minutos.

Efetuada a coloração, montou-se os cortes em glicerina para subsequente exame quantitativo em sistema computadorizado de análise de imagem, constituído por um microscópio (Olympus, Japão) ou lupa ao qual se encontrava acoplada câmera de vídeo que se conectava a um microcomputador AT-486, equipado com placa apropriada e com o programa BIOSCANOPTIMAS 4.1 (Edmonds, CA, EUA).

Para tanto, após calibração do equipamento, delimitou-se as áreas de interesse com 0 cursor, fornecendo o programa automaticamente suas respectivas dimensões em $\mathrm{cm}^{2}$. 


\subsubsection{Exame Histopatológico Através de Coloraçāo pela Hematoxilina e Eosina}

Fragmentos representativos de cada lobo hepático foram também fixados em formüi a $10 \%$, em solução salina tamponada com fosfato (PBS), durante aproximadamente 48 horas.

A seguir, estes materiais foram processados por técnicas rofineiras de desidrataçāo, diafanização e inclusão em parafina, obtendo-se, posteriomente, cortes seriados de aproximadamente $5 \mu \mathrm{m}$. Estes foram, subsequentemente, corados com hematoxlina de HARRIS e easina, basicamente como descrito por JUNQUEIRA e JUNQUEIRA (1983).

\subsubsection{Exame Imunohistoquímico para a BrDU}

Fragmentos representativos de cada lobo hepático contendo áreas consideradas "normais" à macroscopia e lesōes pré-neopiásicas, bem como, eventualmente, neoplásicas, foram fixados em metacarn $(60 \%$ de metanol, $30 \%$ de clorofórmio e $10 \%$ de ácido acéfico glacial; Merck PA) por aproximadamente 48 horas.

Em seguida, estes foram submetidos às técnicas rotineiras de desidratação, diafanização e inclusão em parafina, sendo, então, obtidos cortes seriados de aproximadamente $5 \mu \mathrm{m}$.

Subsequentemente, realizou-se nos mesmos a técnica imunohistoquimica para a BrDU, utilizando-se, para tanto, anticorpos primários monoclonais anti-BrDU (Dako, Dinamarca) na diluiçăo de 1:60 e anticorpos secundários biotinilados anti-imunoglobulinas de coelho (Vector Laboratories, CA, EUA), na diluição de 1:400.

O método utilizado foi basicarnente o da avidina-biotina (HSU et al., 1981), intercalando-se cada procedimento com lavagens das lâminas em solução salina tamponada com fosfało (PBS).

Assim, nesse sentido, logo de inicio os cortes histológicos foram desparafinizados em xilol e hidratados em sequência dos álcoois absoluto, a $95 \%$ e a $70 \%$, e, por último, em água destilada.

A seguir, estes foram incubados por 1 hora em ácido cloridrico $2 \mathrm{~N}$ (Merck, PA), bloqueando-se, subsequentemente, por 30 minutos, a peroxidase endogena através de incubação das lâminas em metanol (Labsynth, PA) contendo $50 \%$ de peróxido de hidrogênio a 30 volumes (Labsynth, PA).

Estes cortes foram, entāo, incubados com os anticorpos primários na diluiçāo já mencionada, por periodo de uma noite, a $4^{\circ} \mathrm{C}$ e em câmara úmida. Para diluição desses anticorpos utilizou-se uma solução contendo soro-albumina a $5 \%$ (albumina bovina fração V-Sigma) em água destilada $(1,25 \mathrm{~mL}$ ), azida sódica a $5 \%$ (Labsynth PA) em água destilada (2,5 mL) e solução salina tamponada (PBS; $59 \mathrm{~mL}$ ).

Em seguida, incubou-se os cortes por 30 minutos com os anticorpos secundários biotinilados na diluição anteriormente citada, seguindo-se a aplicação do conjugado avidinabiotina-peroxidase Nectastain-ABC kit, Vector) diluido em PBS (1:400), por 30 minutos, e, posteriormente, de solução contendo substrato da peroxidase preparada imediatamente antes da utilizaçăo e consistindo na mistura de peróxido de hidrogènio a 0,02\% (Merck PA) com 3,3'-diaminobenzidina (Sigma) a 0,1\% em PBS.

Finalmente, estes foram lavados em PBS por 5 minutos, contracorados com hematoxilina, desidratados, diafanizados e montados com resina sintėtica. 


\subsection{Quantificação dos Hepatócitos Marcados com BrDU}

Para a quantificação dos hepatóciius marcados com a BrDU (Figura 4), foram contados 1000 núcleos de hepatócitos no tecido considerado "normal" ao redor das lesões préneoplásicas e neoplásicas, compreendendo aproximadamente 350 núcleos em cada uma das três zonas de RAPPAPORT e 1000 núcleos de hepatócitos nas áreas de lesão. Segundo RAPPAPORT et al. (1954), classifica-se como zona I do parênquima hepático as regiōes situadas ao redor dos vasos aferentes, como zona ll as regiões intermediárias entre as zonas I e III, e como zona III as regiões próximas às veias centrolobulares.

Os resultados foram expressos através do indice de marcação (I.M.), utilizando-se a seguinte fórmula:

I.M. = $\frac{\text { No de núcleos positivos para a BrDU } \times 100}{N^{\circ} \text { total }}$

No total de núcleos contados 
Figura 4. Núcleos de hepatócitos corados em marrom (seta) apresentando padrão tipico de marcação de BrDU. (Estreptavidina-biotina-peroxidase/Hematoxilina, 560x) 


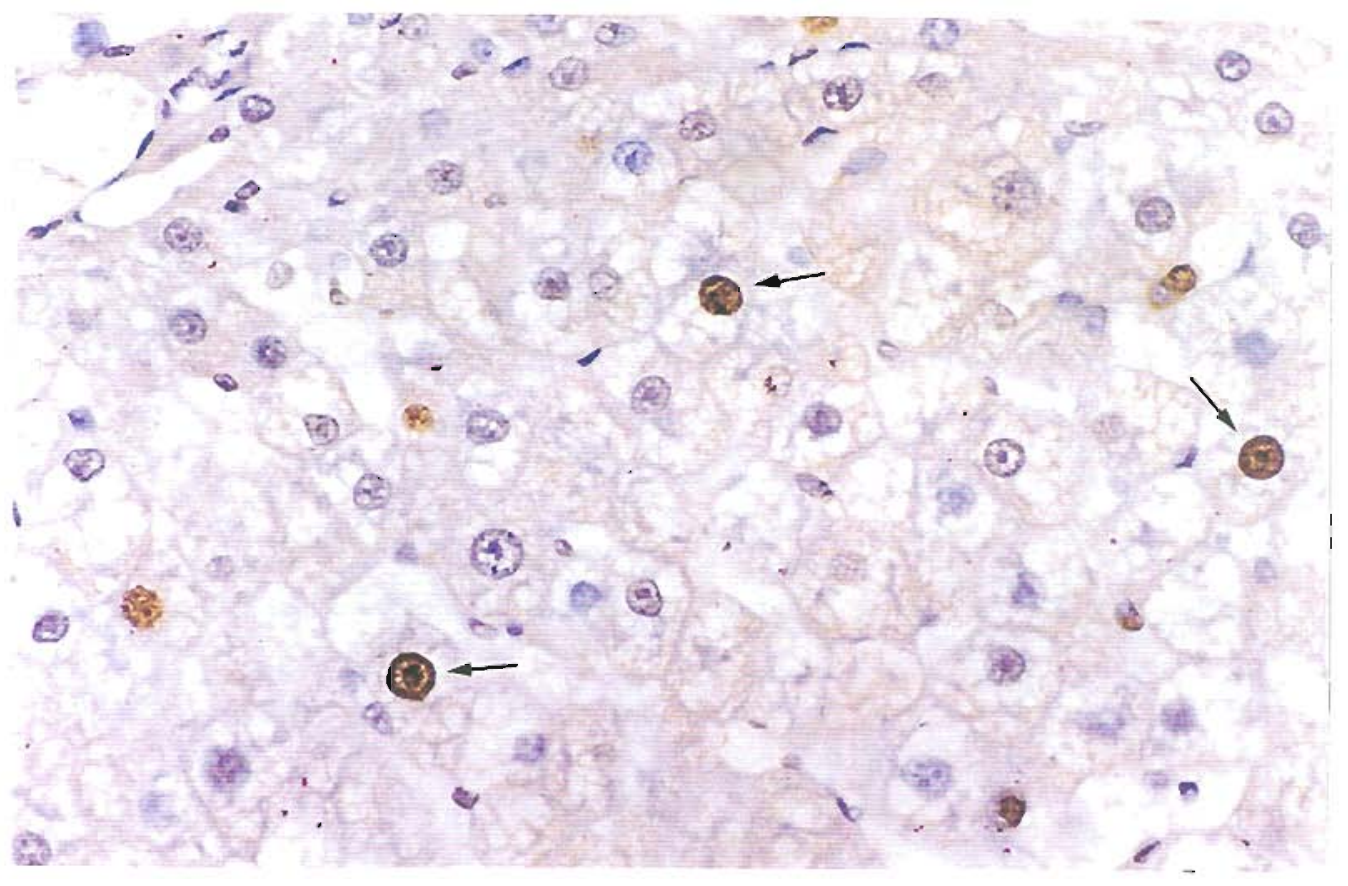




\subsection{Determinação das Concentrações Hepáticas de $\beta$-caroteno e retinol}

Para a determinaçăo das concentrações hepáticas de $\beta$-caroteno e retinol, colheu-se, durante 0 sacrificio, amostras com aproximadamente $1 \mathrm{~g}$ do lobo direito do figado dos animais, de áreas consideradas "normais" ao exame macroscópico. Estas foram rapidamente congeladas em nitrogênio liquido e transportadas em gelo seco, para subsequente estocagem em congelador a $-70^{\circ} \mathrm{C}$.

As análises de $\beta$-caroteno e refinol no figado foram realizadas atraves de cromatografia liquida de alta eficiência (CLAE).

Para tanto, realizou-se, logo de inicio, os processos de saponificação e extraçāo do retinol e $\beta$-caroteno, basicamente de acordo com AL-ABDULALY e SIMPSON (1989).

Assim, o figado foi pesado em tubo de ensaio e homogeneizado com triturador tpo Turrax (Marconi, SP, Brasil), utilizando-se aproximadamente $2 \mathrm{~mL}$ de água destilada. A seguir, adicionou-se $30 \mathrm{~mL}$ de $\mathrm{KOH}$ metanólico a $30 \%$ (Synth PA) (p/v), deixando-se a mistura ern repouso durante uma noite, no escuro, sob nitrogênio e à temperatura ambiente.

Ao término desse periodo, a mistura foi tansferida para un erlènmeyer contendo $50 \mathrm{~mL}$ de éter etilico (Synth PA) e agitada mecanicamente por 15 minutos, sendo, entāo, transferida para um funil de separação, onde se descartou a fase metanólica.

A seguir, removeu-se o álcali residual presente na fase etérea através de sucessivas lavagens com água destilada, transferindo-se, subsequentemente, a solução para um erlenmeyer e refirando-se a água remanescente através da adição de sulfato de sódio anidro (Synth PA).

O éter etílico contendo o $\beta$-caroteno e o retinol foi, então, transferido para um balão e evaporado até à secura, em rota-evaporador a vácuo (Tecnal, SP, Brasil).

Em seguida, lavou-se esse balảo com $2 \mathrm{~mL}$ de éter etilico e separou-se a solução em duas aliquotas de $1 \mathrm{~mL}$ cada, evaporando-se subsequentemente o éter com nitrogênio. $A$ uma dessas aliquotas adicionou-se 0,3 a $0,5 \mathrm{~mL}$ de metanol (Merck, grau HPLC) para a determinação de $\beta$-caroteno, e na outra cerca de 0,5 a 2,0 mL de hexano (Merck, grau HPLC) para análise de retinol.

Antes da injeção no cromatógrafo as amostras foram filtradas em membranas de 0,45 $\mu \mathrm{m}$ de malha.

O $\beta$-caroteno presente no figado foi determinado através de cromatografia de fase reversa, basicamente de acordo com SCHMITZ et al. (1991).

Para tanto utilizou-se cromatógrafo Shimadzu LC9A (Japão) com sistema de bombearnento para multisolventes, auto-injetor e detector UV-VIS. Aliquotas com volume correspondente a $20 \mu \mathrm{L}$ foram injetadas no aparelho, sendo o carotenóide separado em coluna C18 (Vydac 201 TP 54; 5 um, $250 \times 4,6 \mathrm{~mm}$ Dil) e eluido através de fase móvel consistindo em uma mistura de metanol (Merck grau HPLC), acetonitrila (Merck grau HPLC) e água (88:9:3 v/v/v), com fluxo de $2 \mathrm{~mL}$ minuto. A deteç̧āo foi realizada no comprimento de onda de $452 \mathrm{~nm}$.

Por outro lado, a determinação do retinol no figado foi realizada através de cromatografia líquida em fase normal, basicamente de acordo com RETTENMAIER e SCHUEP (1992), e empregando o mesmo cromatógrafo e sistema de bombeamento e injeção descritos acima, com exceção do detector, que no caso foi de fluorescência.

Além disso, para a separação do retinol nas aliquotas de $20 \mu \mathrm{L}$ que foram injetadas no aparelho, utilizou-se coluna de silica com micro-esferas de $5 \mu \mathrm{m}, 6 \mathrm{~mm}$ de diâmetro interno e $15 \mathrm{~cm}$ de comprimento (Shimadzu, Japão), bem como sistema de eluiçāo isocrático ( fluxo de 
2,0 mL/minuto) com fase móvel consistindo de uma mistura de hexano (Merck grau HPLC) com isopropanol (Merck grau HPLC), na proporção de $99: 1$ (v/v). Para a detecção, os comprimentos de onda empregados foram: emissão $=480 \mathrm{~nm}$ e excitaçāo $=330 \mathrm{~nm}$.

De acordo com essas condições experimentais, o tempo de retenção do $\beta$-caroteno foi de aproximadamente 12 minutos e o da vitamina $A$ de 8 minutos, tendo sido estes identificados através de comparação com os tempos de retenção dos picos dos padrões correspondentes, ou seja, do $\beta$-caroteno todo-trans (Sigma) e do retinol todo-trans (Sigma).

Da mesma forma, a quantificaçāo desses compostos foi feita através de determinação das áreas dos picos e comparação com os respectivos padrōes, utilizando-se curvas de calibração. Antes da construção das mesmas verificou-se o grau de pureza dos padrões, conforme descrito no item 3.3.

\subsection{Determinação da Concentração Hepática de DNA}

Para a determinação da concentração hepática de DNA foi utilizado o método bioquímico de BURTON (1956), realizando-se as análises em duplicatas e com repetçōes, em amostras contendo aproximadamente $1 \mathrm{~g}$ de figado obtidas de regiōes do lobo direito consideradas "normais" ao exame macroscópico, e armazenadas a $-70^{\circ} \mathrm{C}$.

Assim, após pesagem de $500 \mathrm{mg}$ de figado em balança eletrônica digital estes foram triturados em homogeneizador tipo Potter-Elvehjem com $3 \mathrm{~mL}$ de ácido perclórico (PCA; Merck PA) $1 \mathrm{~N}$ gelado, centrifugando-se o hornogeneizado, subsequentemente, a 8000 r.p.m. (centrifuga Sorvall Instruments, EUA, modelo RC5C, rotor SS34) por 10 minutos, à temperatura de $4{ }^{\circ} \mathrm{C}$.

Desprezou-se, em seguida, o sobrenadante.

A seguir, com auxilio de bastão de vidro, dissolveu-se o precipitado em $6 \mathrm{~mL}$ de PCA 0,5 $\mathrm{N}$ gelado, agitou-se o mesmo por 2 minutos em agitador de tubos (Marconi, modelo 162, SP, Brasil) e centrifugou-se a suspensão a 8000 r.p.m., por 10 minutos e à temperatura de $4^{\circ} \mathrm{C}$.

Este procedimento foi repetido por mais duas vezes.

A seguir, ressuspendeu-se o precipitado em $4 \mathrm{~mL}$ de PCA 0,5 $\mathrm{N}$ gelado com ajuda de bastão de vidro, colocando-se, então, a suspensão em banho-maria (New Brunswick Scientific, modelo R76, NJ, EUA) a $70^{\circ} \mathrm{C}$, por 1 hora.

Decorrido esse período, e durante o qual se tomou a cautela de agitar manualmente a suspensão a cada 5 minutos, esta foi centrifugada a 8000 r.p.m. por 10 minutos à temperatura de $4^{\circ} \mathrm{C}$, armazenado-se, em seguida, o sobrenadante a $4^{\circ} \mathrm{C}$.

Para a determinação da concentração de DNA nesse sobrenadante pipetou-se, então, $100 \mu \mathrm{L}$ dessa amostra em tubo de vidro, adicionando-se $900 \mu \mathrm{L}$ de PCA $0,5 \mathrm{~N}$ e $2 \mathrm{~mL}$ de uma solução de difenilaminalacetaldeído, armazenando-se subsequentemente a solução por 17 horas as abrigo da luz

A solução de difenilaminalacetaldeido consistiu no seguinte: $50 \mathrm{~mL}$ de solução de difenilamina [750 mg de difenilamina (Sigma), $50 \mathrm{~mL}$ de ácido acético glacial (Merck PA) e $750 \mu \mathrm{L}$ de ácido sulfúrico concentrado (Merck PA), juntamente com $250 \mu \mathrm{L}$ da solução de acetaldeido (125 $\mu \mathrm{L}$ de acetaldeído - Fuka Chemie AG, Suiça - em $6 \mathrm{~mL}$ de água destilada)].

A leitura da absorbância foi realizada em espectofotồmetro Hitachi modelo U3410 (Japão), no comprimento de onda de $600 \mathrm{~nm}$, determinando-se a concentração de DNA através de comparaçāo com curva padrāo construida através da utilizaçāo de DNA de timo de vitela (Sigma). 


\subsection{Análise do Padrảo de Metilação dos proto-oncogenes c-Ha-ras e c-myc, bem como do Gene que Codifica para a Enzima HMGCoA Redutase}

\subsubsection{Isolamento do DNA Genômico}

A avaliação do padrāo de metilação dos proto-oncogenes c-Ha-ras e c-myc, bem como do gene que codifica para a a enzima HMGCOA redutase, foi realizada em amostras de figado de ratos normais, bem como de regiōes de tecido hepático do lobo direito consideradas "normais" à macroscopia e de lesōes pré-neoplásicas/neoplásicas de ratos submetidos ao modelo do RH e tratados com óleo de milho, $\beta$-caroteno ou vitamina $A$ da $40^{\circ}$ à $48^{\circ}$ semana do estudo, colhidas durante o sacrificio e armazenadas a $-70^{\circ} \mathrm{C}$.

Para tanto, procedeu-se, logo de inicio, ao isolamento do DNA genômico das mesmas mediante centrifugação diferencial (centrifuga Sorvall RC5C, rotor SS34), e basicamente de acordo com o descrito por RAJALAKSHMI et al. (1978).

Assim, 0,5-1,0 g de tecido de cada amostra foi homogeneizado, inicialmente, em um triturador Potter-Elvehjem na presença de solução de $\mathrm{NaCl}$ (Sigma) $0,075 \mathrm{M}$, ácido etilenodiaminotetracético (EDTA; Sigma) 0,025 M e Triton X-100 (Sigma) 0,1\% e, logo após, centrifugado a 3500 r.p.m., por 10 minutos e a $4{ }^{\circ} \mathrm{C}$.

A seguir, o precipitado foi ressuspendido em soluçäo de cloridrato de trishidroximetlaminometano (Tris-HCl; Sigma) 0,05 M (pH 7,6) contendo 0,1\% de Triton e centuifugado a 3500 r.p.m., por 10 minutos e a $4^{\circ} \mathrm{C}$.

Repetiu-se esse procedimento por duas vezes, seguindo-se duas outras "lavagens" do precipitado com solução de Tris- $\mathrm{HCl} 0,05 \mathrm{M}, \mathrm{pH} 7,6$.

Em seguida, ressuspendeu-se, novamente, o precipitado de núcleos em solução de Tris- $\mathrm{HCl} 0,05 \mathrm{M}(\mathrm{pH} 7,6)$ contendo $0,1 \%$ de Triton $X-100$ e centrifugou-se a 3500 r.p.m, por 10 minutos a $4{ }^{\circ} \mathrm{C}$. Tais "lavagens" foram efetuadas por duas vezes, seguindo-se duas outras "lavagens" com solução de Tris- $\mathrm{HCl} 0,05 \mathrm{M}, \mathrm{pH} 7,6$.

O precipitado resultante foi ressuspendido, agora, em solução de Tris- $\mathrm{HCl} 0,01 \mathrm{M}$ $(\mathrm{pH} 8,0)$, e centrifugado a 3500 r.p.m por 10 minutos, a $4{ }^{\circ} \mathrm{C}$.

A cromatina solubilizada nessa solução de Tris- $\mathrm{HCl} 0,01 \mathrm{M}(\mathrm{pH} 8,0)$, foi então desproteinizada, após adição de $\mathrm{NaCl}$ a uma concentração final de $1 \mathrm{M}, \mathrm{com} 100 \mu \mathrm{g} / \mathrm{mL}$ de proteinase $\mathrm{K}$ (Sigma), pelo periodo de uma noite, a $37^{\circ} \mathrm{C}$ e sob agitaçāo continua.

A seguir, adicionou-se à essa cromatina digerida um volume igual de solução de clorofórmio:álcool isoamílico (Sigma) $(24: 1, \mathrm{v} / \mathrm{V}$ ), agitando-se a mesma delicadamente por 30 minutos, à temperatura ambiente. Após centrifugação a 5000 r.p.m. por 20 minuto, recolheu-se a fase aquosa cuidadosamente, procurando-se evitar contaminação com a camada de proteinas desnaturadas, estratificada na interface com a fase orgânica.

Em seguida, após adição de dois volumes de álcool etilico absoluto (Merck PA) gelado, realizou-se precipitaçāo do DNA por periodo de uma noite, à temperatura de $-20^{\circ} \mathrm{C}$.

O precipitado foi ressuspendido em soluçāo de $\mathrm{NaCl}$ a $0,01 \mathrm{M}$ e Tris- $\mathrm{HCl} 0,01 \mathrm{M}(\mathrm{pH} 8,0)$, eliminando-se, subsequentemente, o RNA contaminante através do tratamento com $100 \mu \mathrm{g} / \mathrm{mL}$ de RNase livre de DNase (RNase A, Pharmacia Biotech, EUA), por 2 horas e à temperatura de $37^{\circ} \mathrm{C}$.

A seguir, realizou-se nova extração com solução de clorofórmio:álcool isoamílico e precipitação em etanol absoluto, como descrito anteriormente. O DNA purificado foi, então, "lavado" em etanol a 70\%, secado á temperatura ambiente e dissolvido em soluçāo de Tris- $\mathrm{HCl}$ $0,01 \mathrm{M}(\mathrm{pH} 8,0)$. Posteriomente, sua concentração foi determinada em um comprimento de onda de $260 \mathrm{~nm}$, utilizando-se, para tanto, espectofotômetro Hitachi modelo U3410 (Japão). 


\subsubsection{Digestão do DNA Genômico com Enzimas de Restrição}

Para avaliação do padrão de metilação dos oncogenes c-Ha-ras e c-ri,yc, bem como do gene que codifica para a enzima HMGCoA redutase, o DNA genômico $(10 \mu \mathrm{g})$ extraido das amostras de figado foi, então, submetido à digestão com 5 U/ug de DNA das enzimas de restrição Hpa ll e Msp I (Pharmacia), por 3 horas e à $37^{\circ} \mathrm{C}$.

Após a digestão, e previamente à eletroforese das amostras de DNA digerido em gel de agarose a $1 \%$ (Sigma), adicionou-se às mesmas $3 \mu \mathrm{L}$ de solução contendo glicerol a $30 \% \mathrm{em}$ água grau reagente tipo I (Milli-Q Plus, Millipore Co., EUA), EDTA (Sigma) a $1 \mathrm{mM}$, azul de bromofenol (Sigma) a 0,25\% e xileno cianol FF (Sigma) a 0,25\%.

\subsubsection{Eletroforese em Gel de Agarose e Transferência para Suporte Sólido}

Os fragmentos de restrição resultantes da digestão do DNA genômico (10 $\mu \mathrm{g}) \mathrm{com}$ as enzimas Hpa II e Msp I, bem como amostra de DNA de fago $\lambda$ digerido com a enzima de restrição Hind III (Sigma) e utilizado como marcador, foram então separados abavés de elefroforese horizontal em gel de agarose (Sigma) a 1\%, durante 16 horas, a $20 \mathrm{~V}$ e em tampão TPE 1x contendo Tris- $\mathrm{HCl} 0,036 \mathrm{M}, \mathrm{NaH}_{2} \mathrm{PO}_{4}$ (Sigma) 0,03 $\mathrm{M}$ e Na2 EDTA (Sigma) 0,01 M, $\mathrm{pH}$ 7,5. Subsequentemente, fotografou-se (Polaroid, modelo DS 34; England) o gel em transiluminador equipado com luz UV (Pharmacia) e utilizando-se filme Polaroid 667, após coloraçāo do mesmo com brometo de etídio $(0,5 \mu \mathrm{g} / \mathrm{mL}$; Sigma).

A seguir, transferiu-se o DNA para membrana de nitrocelulose com suporte (Schleicher \& Schuell $0,45 \mu \mathrm{m}$ ), basicamente de acordo com método descrito originalmente por SOUTHERN (1975).

Рara tanto despurinizou-se previamente o DNA, imergindo-se o gel por 15 minutos em $\mathrm{HCl}$ (Merck PA) 0,2 M. Além disso, após lavagem do gel com água grau reagente tipo I desnaturou-se o DNA em solução contendo $\mathrm{NaOH}$ (Merck PA) 0,5 M e NaCl 1,5 M, por 15 minutos. Este procedimento foi repetido, com subsequente neutralização em tampão contendo Tris-HCl 0,5 M pH 7,5 e NaCl 1,5 M, por 30 minutos. Cada uma dessas etapas foi realizada com suave agitação do gel mergulhado nas respectivas soluções, e à temperatura ambiente.

A transferência foi efetuada por capilaridade durante periodo compreendendo cerca de 18-20 horas, através da ưfilização de papel de filtro 3 MM Chr. (Whatman International Ltd., England) e tampão SSC 20x pH 7,0 ( $\mathrm{NaCl} 3 \mathrm{M}$, citrato de sódio 0,3 M).

Em seguida, fixou-se irreversivelmente o DNA à membrana de nitrocelulose, expondo-se a mesma por 2 horas a uma temperatura de $80^{\circ} \mathrm{C}$, em forno à vácuo $(25 \mathrm{~mm} \mathrm{Hg}$; Fanem modelo 099, Brasil).

\subsubsection{Pré-hibridizaçāo, Hibridização, Lavagem da Membrana e Autorradiografia}

Tais procedimentos foram realizados, basicamente, de acordo com o descrito por SAMBROOK et al. (1989).

Assim, a membrana de nitrocelulose contendo o DNA genômico digerido foi préhibridizada, logo de início, em forno de hibridização (Techne modelo HB200; Techne 
(Cambridge) Ltd., England), por uma noite e a $42^{\circ} \mathrm{C}$, em um excesso de solução $\left(0,1 \mathrm{~mL} / \mathrm{cm}^{2}\right.$ de membrana) contendo: formamida desionizada a $50 \%$ (Sigma), SSC $6 x$, solução de Denhardt $5 x$ $(0,5 \mathrm{~g}$ Ficol 400 [Pharmacia], polivinilpirrolidona [Sigma], albumina bovina fração $V$, dodecilsulfato de sódio (SDS; Sigma) a 0,5\%, $\mathrm{NaH}_{2} \mathrm{PO}_{4}$ 0,05M pH 7,0 e $100 \mu \mathrm{g} / \mathrm{mL}$ de DNA sonicado de esperma de salmão (Pharmacia) desnaturado mediante fervura por 10 minutos e rápido resfriamento em gelo por 2 minutos.

Subsequentemente, por ocasião da etapa de hibridização, conduzida a $42^{\circ} \mathrm{C}$ e por 48 horas, adicionou-se à solução de pré-hibridização a sonda marcada com ${ }^{32} \mathrm{P}$, após desnaturação da mesma através de fervura por 10 minutos e incubação em gelo por 2 minutos.

Decomido o procedimento, descartou-se a solução de hibridização e lavou-se gentilmente a membrana sob agitaçăo, por periodo de 5 minutos e à temperatura ambiente, em uma solução contendo SSC $2 x$ e SDS a $0,5 \%$, e, em seguida, por 15 minutos à temperatura ambiente em uma solução SSC $2 x$ e SDS $0,1 \%$ e, finalmente, por 10 minutos a $52^{\circ} \mathrm{C}$ em uma soluçāo SSC 0,1x e SDS 0,5\%.

Após as lavagens, e enquanto ainda úmida, envolveu-se a membrana em filme de PVC, retirando-se o excesso de líquido através de suave compressão manual sobre a mesma. Em sala escura apropriada, esta foi então colocada entre filmes radiográficos X-OMAT-K (Eastman Kodak Co., NY, EUA), inserindo-se, em seguida, todo o conjunto em um chassi de metal contendo telas intensificadoras (Imagem Lanex, base verde; Eletro Médica, Brasil), que foi posteriormente armazenado a $-70^{\circ} \mathrm{C}$.

Decorrido o tempo adequado de exposição (de um dia a uma semana), revelou-se e fixouse os filmes radiográficos utilizando-se, para tanto, revelador e fixador GBX (Kodak Brasileira Com. Ind. Lıda; Brasil), respectivamente, de acordo com as instruçōes do fornecedor.

\subsubsection{Origem das Sondas e suas Marcações}

As sondas v-Ha-ras, de rato, com 0,73 kb, e c-myc humana, com 1,4 kb e para o $3^{\circ}$ éxon, foram adquiridas da Oncor ${ }^{\circledR}$, Gaithersburg, MD, EUA.

Por outo lado, a sonda para o gene da HMGCoA redutase foi gentilmente cedida pelo Prof. Dr. D.S.R. Sarma, do Departamento de Patologia da Faculdade de Medicina da Universidade de Toronto, Canadá, e consistia em um fragmento com 4,5 kb do plasmidio pRed227 (ATCC), representando o cDNA para a HMGCoA redutase de hamster e contendo toda a região codificante, bem como 163 pb da região $5^{1}$ não-traduzivel e $1,65 \mathrm{~kb}$ da sequència 3' não-traduzivel (CHIN et al., 1984).

Estas foram marcadas com $\alpha$-32P-dCTP (Amersham, sp. act. $6000 \mathrm{Ci} / \mathrm{mmol}$ ) utilizando-se o conjunto Multiprime DNA Labelling System da Amersham, de acordo com as instruçōes do fornecedor e essencialmente conforme os procedimentos descritos por FEINBERG e VOGELSTEIN (1983b, 1984).

Após a marcação por periodo de uma noite, as sondas foram purificadas dos nucleotideos marcados não-incorporados, mediante filtração em gel de Sephadex G-50, utilizando-se, para tanto, colunas descartáveis (Nick ${ }^{\circledR}$ Column; Pharmacia). Foram obtidas, rotineiramente, sondas com atividades especificas correspondendo a (1-3) $\times 10^{9} \mathrm{cpm} / \mu \mathrm{g}$ de DNA. 


\subsection{Análise Estatística}

Quando indicado, a análise estatística dos resultados foi realizada com auxilio do programa INSTAT para microcomputador (GraphPad Software V2.01 - Copyright 1990-1993).

Assim, logo de inicio, para se verificar a existência de diferenças significantes entre os diversos grupos experimentais ut́lizou-se o teste de Kruskall-Wallis, análise de variância năo-paramétrica capaz de verificar heterogeneidade entre grupos em que $0 \mathrm{n}<30$. Quando isto ocorreu, empregou-se, logo a seguir, o teste não-paramétrico de Mann-Whitney com nivel de confiança de 95\%, para a realização de comparações grupo a grupo (GAD e WEIL, 1989). 


\section{RESULTADOS}

\subsection{Curva Ponderal dos Animais Durante Aplicação do Modelo dz Hepatocarcinogênese}

A Figura 5 demonstra curva que ilustra o comportamento durante os primeiros sessenta dias do estudo, dos pesos corporeos dos ratos Wistar que foram submetidos ao modelo de hepatocarcinogênese do "hepatócito resistente" (RH). Pode-se observar nessa Figura que durante esse periodo os animais tenderam, de uma forma geral, a ganhar peso, exceto durante quatro dias após a aplicação intraperitoneal do carcinogênico iniciante dietilnitrosamina (DEN) e durante a fase de administração das 6 doses de 2-acetilaminofluoreno (2-AAF) por intubação gástrica, quando este se manteve praticamente constante, bem como após a realização da hepatectomia parcial a $70 \%$, quando houve, inclusive, e como esperado, decréscimo ponderal.

Estas variações devem refletir, portanto, além do crescimento normal esperável em ratos jovens, os momentos em que estes sofreram as respectivas intervençōes relativas à aplicação do modelo de hepatocarcinogênese e as próprias toxicidades da DEN e do 2-AAF, nas concentrações em que foram empregados.

Decorridos esses sessenta dias, os animais foram distribuidos em tês grupos experimentais a serem tratados a partir da 40 semana da aplicação da DEN, com óleo de milho (grupo OM - controles), $\beta$-caroteno (grupo $\beta C$ ) ou vitamina A (grupo VA), respectivamente (Figura 1). 
FIGURA 5. Curva de peso dos ratos Wistar durante a aplicação do modelo do "hepatócito resistente".

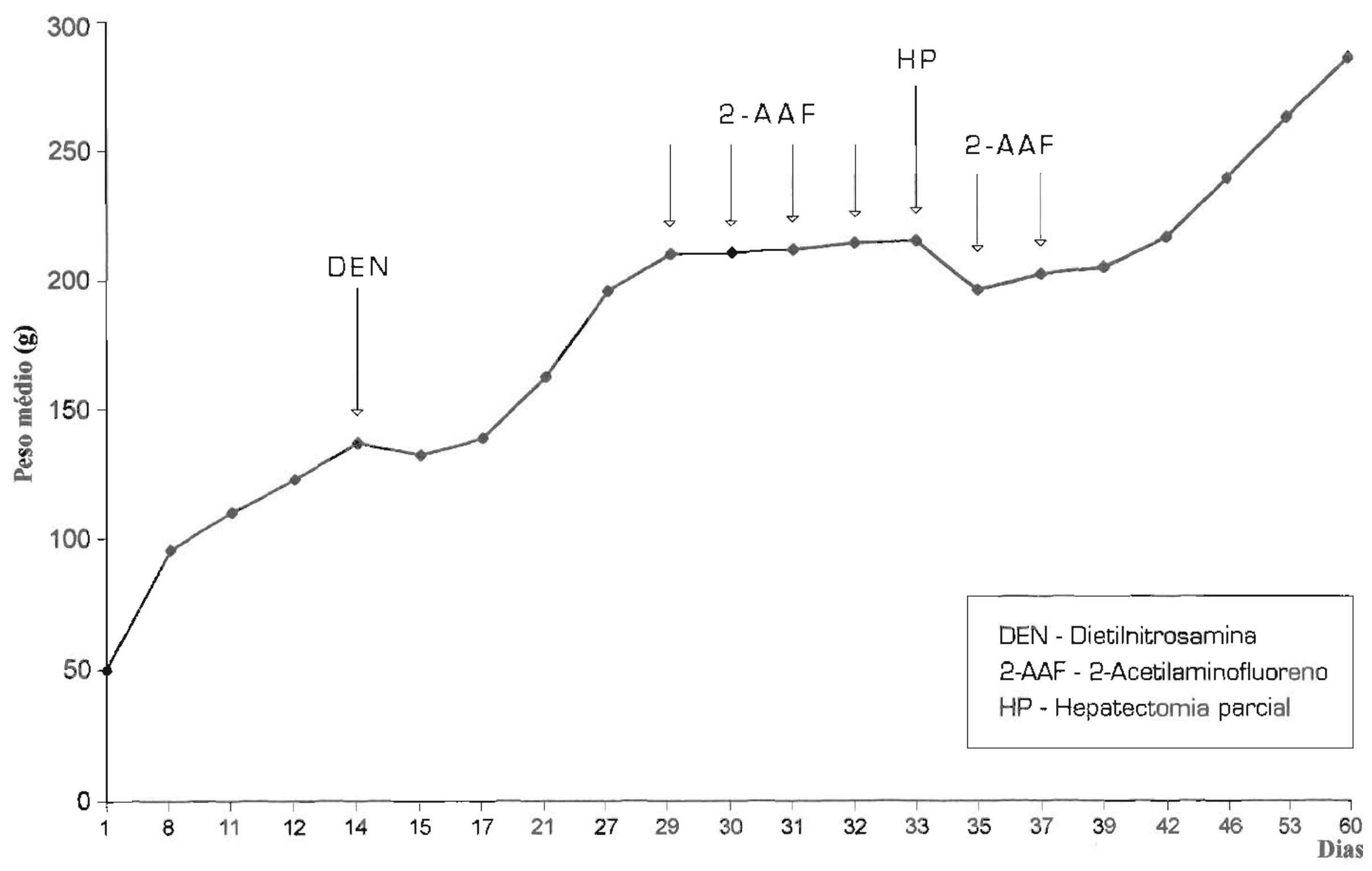




\subsection{Pesos Corpóreos ao Início e Final do Tratamento, Bem como Pesos dos Fígados por Ocasião do Sacrificio}

Assim, após 40 semanas da realização do processo de iniciação com DEN deutse inicio ao tratamento dos animais dos grupos experimentais OM (controles), $\beta C$ e VA, com óleo de milho, $\beta$ caroteno ou vitamina $A$, respectivamente, e que se estendeu por oito semanas consecutivas, quando, então, os ratos foram sacrificados durante a fase de progressão do modelo do "hepatócito resistente".

Desta forma, a Tabela 1 demonstra os pesos corpóreos dos animais quando do ínicio do tratamento e do sacrifico, bem como os pesos de seus figados nessa ocasião.

Tabela 1. Pesos corpóreos e dos fígados de ratos Wistar submetidos ao modelo do "hepatócito reslstente" e tratados com óleo de milho (grupo OM - comtroles), $\beta$-caroteno (grupo $\beta C$ ) ou vitamina A (grupo VA), por 8 semanas consecutivas, durante a fase de progressão da hepatocarcinogênese.

\begin{tabular}{|c|c|c|c|c|c|}
\hline Grupos & $\mathbf{N}$ & $\begin{array}{l}\text { Peso } \\
\text { corpóreo } \\
\text { inicial' } \\
\text { (g) }\end{array}$ & $\begin{array}{l}\text { Peso } \\
\text { corpóreo } \\
\text { final' } \\
\text { (g) }\end{array}$ & $\begin{array}{l}\text { Peso do } \\
\text { fígado } \\
\text { (g) }\end{array}$ & $\begin{array}{l}\text { Peso relativo } \\
\text { do figadolío0 } \\
\text { g de peso } \\
\text { corpóreo }\end{array}$ \\
\hline OM & 8 & $496,6 \pm 37,9$ & $501,0 \pm 41,2$ & $23,4 \pm 7,5$ & $4,7 \pm 1,7$ \\
\hline$\beta C$ & 8 & $491,0 \pm 55,0$ & $507,0 \pm 36,9$ & $18,5 \pm 4,7$ & $3,6 \pm 0,9$ \\
\hline VA & 8 & $494,0 \pm 56,1$ & $499,4 \pm 47,6$ & $19,7 \pm 8,4$ & $4,0 \pm 1,7$ \\
\hline
\end{tabular}

Pode-se observar nessa Tabela, a homogeneidade dos pesos corpóreos dos animais dos tềs grupos experimentais, por ocasiāo do início das administraçōes de óleo de milho (grupo OM - contoles), $\beta$-caroteno (grupo $\beta C$ ) ou vitamina A (NA) na $40^{\text {a }}$ semana após aplicação do carcinogênico iniciante DEN.

Aos 12 meses de experimento, ou seja, após 8 semanas consecutivas de tratamento $e$ quando do sacrificio dos animais na fase de progressão do modelo do RH, observa-se ainda na Tabela 1 que os pesos corpóreos dos ratos dos três grupos experimentais praticamente não diferiram entre si, e que os pesos dos animais dos grupos VA e OM se mantiveram praticamente inalterados em relação a seus respectivos pesos apresentados por ocasião do inicio das aplicaçōes na $40^{\mathrm{a}}$ semana, enquanto houve certa tendência, embora não estatisticamente significante de acordo com o teste de Mann Whitney para amostras não-pareadas, destes aumentarem no grupo $\beta C$. Isto pode indicar que as doses administradas do carotenóide, e até mesmo do refinóide, nảo resultaram no presente estudo em toxicidade geral digna de nota.

Por outro lado, embora também não resultando em diferenças significantes do ponto de vista estatistico de acordo com o teste de Mann Whitney para amostras não-pareadas, os pesos dos figados, inclusive dos relativos, dos animais tratados com $\beta$-caroteno (grupo $\beta C$ ) ou vitamina A (grupo VA) durante 8 semanas consecutivas e sacrificados 12 meses após aplicaçāo 
da DEN, tenderam a ser menores do que os dos ratos que receberam tão somente óleo de milho durante esse mesmo período (grupo OM - controles) (Tabela 1). Estas observações sugerem que as doses administradas do carotenóide, ou da vitamina A, não resultaram, da mesma forma, em hepatotoxicidade digna de nota nessas condições experimentais, podendo ainda refletir, inclusive, a presença de lesóes neoplásicas malignas constatada em maior número no grupo OM (controles) (Tabela 2).

\subsection{Quantificaçāo das Lesões Nodulares e de Cânceres Observados Macroscopicamente}

A Tabela 2 apresenta a observação macroscópica de figados de ratos Wistar submetidos ao modelo de hepatocarcinogènese do "hepatócito resistente", tratados a partir da $40^{\text {a }}$ semana do experimento com óleo de milho (grupo OM - controles), $\beta$-caroteno (grupo $\beta C$ ) ou vitamina A (grupo VA) durante 8 semanas consecutivas, e sacrificados, portanto, ao término da $48^{\text {a }}$ semana do estudo, em fase adequada à constatação da presença de neoplasias malignas.

Nessa etapa do processo de hepatocarcinogênese desencadeado pelo modelo do $\mathrm{RH}$ em ratos Wistar, ou seja, 1 ano após a aplicaçăo do carcinogênico iniciante DEN, espera-se constatar ao exame macroscópico, em maior ou menor número de animais, a presença simultânea nos figados dos mesmos, de uma quantidade variável de nódulos persistentes de hepatócitos ou cànceres.

Tabela 2. Quantificação das lesões nodulares macroscópicas, bem como de cânceres, de ratos Wistar submetidos ao modelo do "hepatócito resistente" e tratados com óleo de milho (grupo OM - controles), $\beta$-caroteno (grupo $\beta C$ ) ou vitamina A (grupo VA) por 8 semanas consecutivas, durante a fase de progressão da hepatocarcinogênese.

\begin{tabular}{cccccc}
\hline Grupos & $\begin{array}{c}\text { No. de ratos } \\
\text { com nódulos } \\
\text { persistentes }\end{array}$ & $\begin{array}{c}\text { Incidêncla de } \\
\text { nódulos } \\
\text { persistentes } \\
(\%)\end{array}$ & $\begin{array}{c}\text { No. total de } \\
\text { nódulos } \\
\text { persistentes }\end{array}$ & $\begin{array}{c}\text { No. de ratos } \\
\text { com câncer }\end{array}$ & $\begin{array}{c}\text { Incidência de } \\
\text { cânceres } \\
(\%)\end{array}$ \\
\hline OM & $5 / 8$ & 62,5 & 26 & $5 / 8$ & 62,5 \\
$\beta C$ & $6 / 8$ & 75,0 & 27 & $2 / 8$ & 25,0 \\
VA & $3 / 8$ & 37,5 & 8 & $2 / 8$ & 25,0 \\
\hline
\end{tabular}

Pode-se constatar na Tabela 2 que ratos submetidos ao modelo do $\mathrm{RH}$ e tratatos com vitamina A (grupo VA), apresentaram por ocasião do sacrificio, em comparação a animais do grupo OM (controles), menores incidências de nódulos persistentes de hepatócitos e cânceres. Além disso, ainda em comparaçāo ao grupo OM, ratos aos quais se administrou esse retinóide natural (grupo VA) por 8 semanas consecutivas durante fase do modelo de hepatocarcinogênese propicia ao desenvolvimento de neoplasias malignas, também apresentaram menor número total de nódulos persistentes de hepatócitos. 
Por outro lado, quando comparados aos contoles (grupo OM), ratos tratados com $\beta$-caroteno (grupo $\beta C$ ) da $40^{\circ}$ à $48^{a}$ semana após iniciação com o carcinogênico DEN, apresentaram maior incidência de nódulos persistentes, mas menor incidência de cânceres, ao exame macroscópico por ocasião do sacrificio (Tabela 2). Além disso, estes apresentaram (grupo $\beta C$ ) praticamente 0 mesmo número total de nódulos persistentes que animais do grupo controle (OM).

\subsection{Quantificação dos Focos e Nódulos de Hepatócltos Marcados Positivamente pela Enzima $\gamma$-glutamiltranspeptidase $(\gamma \mathrm{GT})$}

Os resultados das quantificaçōes dos focos e dos nódulos de hepatócitos marcados positivamente pela enzima rGT apresentados por animais tratados com óleo de milho (grupo OM - controles), $\beta$-caroteno (grupo $\beta C$ ) ou vitamina A (grupo VA) e sacrificados na fase de progressão do modelo do $\mathrm{RH}$, realizadas em sistema de análise de imagem computadorizado, estão apresentados na Tabela 3.

A técnica empregada para marcar a yGT demonstrou resultados satisfatórios no presente estudo, do ponto de vista morfológico. Além de delimitar áreas de hepatócitos alterados (focos ou nódulos pré-neoplásicos), esta revelou que os ductos biliares também se mostravam positivos para essa enzima, da mesma forma que grupos de células alongadas (células ovais) que entremeavam o parênquima hepático e também delimitavam algumas lesões pré-neoplásicas (focos e nódulos de hepatócitos).

Tabela 3. Quantificação dos focos e nódulos pré-neoplásicos (F/N) positivos para a enzima $\gamma$ GT, de ratos Wistar submetidos ao modelo do "hepatócito resistente" e tratados com óleo de milho (grupo OM - controles), $\beta$-caroteno (grupo $\beta C$ ) ou vitamina $A$ (grupo VA) por 8 semanas consecutivas, durante a fase de progressāo da hepatocarcinogênese.

\begin{tabular}{ccccc}
\hline Grupos & $\mathbf{n}$ & $\begin{array}{c}\text { Número de F/N } \\
\text { por } \mathrm{cm}^{2^{*}}\end{array}$ & $\begin{array}{c}\text { Área média de } \\
\text { F/N por } \mathrm{mm}^{2^{*}}\end{array}$ & $\begin{array}{c}\text { \% de Área do } \\
\text { corte ocupada } \\
\text { por F/N }\end{array}$ \\
\hline OM & 8 & $5,68 \pm 4,0$ & $0,80 \pm 0,6$ & $4,11 \pm 3,6$ \\
$B C$ & 8 & $5,51 \pm 3,7$ & $0,47 \pm 0,2$ & $3,25 \pm 2,2$ \\
VA & 8 & $5,71 \pm 2,5$ & $0,48 \pm 0,2$ & $2,78 \pm 2,0$ \\
\hline
\end{tabular}

$\mathrm{n}=$ número de animais

" = os valores representam, respectivamente, média \pm desvio padrão da média.

Pode-se observar na Tabela 3 que foi praticamente idêntico o número de lesōes préneoplásicas (focos e nódulos) marcadas positivamente pela enzima $\gamma \mathrm{GT}$, observado no figado dos animais dos grupos OM (controles), $\beta C$ e VA, ou seja, daqueles submetidos ao modelo do $R H$ e tratados da $40^{\text {a à }} 48^{a}$ semana do estudo com óleo de milho, $\beta$-caroteno ou vitamina $A$, respectivamente, durante a fase de progressão da hepatocarcinogênese. Todavia, pode-se também constatar nessa Tabela que animais tratados com $B$-caroteno (grupo BC) ou vitamina $A$ (grupo VA) por 8 semanas consecutivas, tenderam a apresentar por ocasião do sacrificio ao 
término da 48a semana, lesões pré-neoplásicas (focos e nódulos de hepatócitos) positivas para a enzima yGT com menores áreas médias e que ocupavam menores porcentagens da área do corte, do que ratos do grupo OM (controles). Estas diferenças não atingiram, entretanto, significância do ponto de vista estatıstico, de acordo com o teste de Mann Whitney para amostras não-pareadas.

\subsection{Exame Histopatológico dos Fígados dos Ratos Através de Coloração pela Hematoxilina e Eosina}

\subsubsection{Observação Geral}

Focos e nódulos pré-neoplásicos consistem em áreas em que os hepatócitos se encontram morfologicamente alterados, correspondendo, respectivamente, a diâmetros inferior e igual ou superior ao de um lóbulo hepático. Além disso, esses podem ser predominantemente constituidos por células claras, acidófilas, basófilas, ou serem mistos contendo células claras e acidófilas.

O aspecto histológico dos focos e nódulos de hepatócitos dos ratos submetidos ao modelo de hepatocarcinogênese do "hepatócito resistente" $(\mathrm{RH})$ observado no presente estudo confirmou aqueles decritos na literatura.

Assim, nessas áreas os hepatócitos apresentavam alterações morfológicas assumindo arranjo acinar e comprimindo, no caso dos nódulos, o parénquima hepático.

As células que compunham os focos predominantemente compostos de células claras (focos de células claras) apresentavam-se aumentadas de volume e com seu citoplasma rarefeito. Os núcleos estavam algumas vezes deslocados para um dos polos da célula, mostrando-se pleomóricos e com nucléolos (em número de um, dois ou mais) evidentes. Em geral não se observavam sinusóides no interior desses focos. Além disso, uma população de células alongadas semelhantes às sinusoidais achava-se presente, entremeando os hepatócitos. Com pouca frequência observavam-se células ductulares ("células ovais") envolvendo parcialmente os focos. Desta forma, estes distinguiam-se do parênquima hepático devido às características de suas células, porem não se observava compressão das áreas adjacentes.

Nos focos constituidos predominantemente de células acidófilas focos de células acidofilas), constatavam-se células com volume aumentado e o citoplasma corando-se mais intensamente pela eosina, o que thes conferia coloração avermeihada uniforme. Corpúsculos semelhantes aos de Councilman, considerados apoptóticos, observados também em hepatites tóxicas ou virais, que apresentam volume reduzido em relaçāo às demais células, intensamente acidófilos e com núcleo picnótico, podiam ser vistos principalmente na região mais periférica dos focos de células acidófilas. Nessas células foi possivel se observar pleomorismo nuclear, com a evidenciação de nucléolos únicos ou múltiplos, que se situavam em uma posição central ou periférica em relação à carioteca. Células binucleadas foram ocasionalmente observadas. Além disso, nesse tipo de foco foram vistas figuras de mitose fipicas e atipicas. Entremeando os hepatócitos constou-se a presença de sinusóides e de capilares com a luz dilatada. Uma população de células alongadas semelhantes às que compunham a população sinusoidal, foi também vista em meio aos hepatócitos, dentro dos focos. 
Focos mistos, compostos por células claras e acidófilas, foram também observados em todos os grupos de animais submetidos ao modelo do RH. Neste caso, variava a proporção de um e outro tipos celulares. Sinusóides foram vistos entremeando os hepatócitos alterados, principalmente nas lesões com maior área. A delimitaçāo por "celulas civais" foi vista com maior frequência, neste caso, do que nos focos de células claras.

Foram também observados focos constituidos predominantemente de células basófilas (focos basófilos) constituídos por hepatócitos pequenos e que tinham como caracteristica a intensa basofilia citoplasmática. Em geral não se constatou, neste tipo de lesão, anaplasia nem figuras de mitose.

Quanto aos nódulos de hepatócitos, são válidos os mesmos achados e a mesma classificação que para os focos. Entretanto, alguns dos nódulos diferiam quanto à presença de uma delimitação mais evidente feita às custas principalmente de células alongadas do tipo "células ovais", bem como de outras células alongadas e arredondadas que as acompanhavam, além de tecido conjuntivo.

No parênquima hepático livre de focos ou nódulos foram também observadas alterações hepałocelulares, consistindo principalmente de degeneração vacuolar. Além disso, foram constatados infiltrados inflamatórios constituídos predominantemente por células mononucleares, e situando-se em regiāo peri-portal.

Além da presença no figado dos animais, de focos e nódulos pré-neoplásicos, proliferação de "celulas ovais" e infiltrado inflamatório, foram constatadas, ainda, a colangiofibrose, peliose e a espongiose, bem como a presença, em determinados casos, de lesões neoplásicas benignas e de carcinoma hepatocelular com padrão trabecular ou glandular (Quadro 1).

\subsubsection{Observação Específica}

\section{Grupo OM}

Foram estudados os figados de 8 ratos deste grupo, e os animais apresentaram lesões préneoplásicas (focos e nódulos) distinguíveis nos cortes corados por $\mathrm{H}$ \& E, principalmente de células claras e mistos. Discreta a moderada inflamação peri-portal foi constatada, além de discreta degeneraçăo vacuolar em hepatócitos peri-portais. Lesões neoplásicas benignas e malignas foram observadas, bem como outras lesões hepáticas, conforme apresentado no Quadro 1 a seguir.

\section{Grupo $\beta C$}

Foram estudados os figados de 8 ratos deste grupo. Estes apresentaram focos e nódulos préneoplásicos distinguiveis nos cortes corados por $\mathrm{H} \& \mathrm{E}$, principalmente de céfulas claras e mistos. Discreta a moderada inflamação peri-portal foi constatada, além de discreta degeneração vacuolar em hepatócitos peri-portais. Lesōes neoplásicas benignas e malignas foram observadas, bem como outras lesões hepáticas, conforme apresentado a seguir no Quadro 1.

\section{Grupo VA}

Foram estudados os figados de 8 ratos deste grupo. Estes apresentaram focos e nódulos de hepatócitos distinguiveis nos cortes corados por H \& E, principalmente de células claras e mistos. Discreta a moderada inflamação peni-portal foi constatada, além de discreta degeneração vacuolar em hepatócitos peri-portais. Lesōes neoplásicas benignas e malignas foram vistas, bem como outras lesōes hepáticas, conforme apresentado no Quadro 1 a seguir. 
Quadro 1. Incidência e descrição das lesōes neoplásicas benignas e malignas, bem como de outras lesões hepáticas, de ratos Wistar submetidos ao modelo do "hepatócito resistente" e tratados com óleo de milho (grupo OM - controles), $\beta$-caroteno (grupo $\beta C$ ) ou vitamina A (grupo VA) por 8 semanas consecutivas, durante a fase de progressão da hepatocarcinogênese.

\begin{tabular}{|c|c|c|c|}
\hline Grupo & $\begin{array}{c}\text { Incidência (\%) e Tipos } \\
\text { de lesōes neoplásicas } \\
\text { benignas }\end{array}$ & $\begin{array}{c}\text { Incidência (\%) e Tipos } \\
\text { de lesōes neoplásicas } \\
\text { malignas }\end{array}$ & $\begin{array}{c}\text { Incidência (\%) e Tipos } \\
\text { de outras lesōes } \\
\text { hepáticas }\end{array}$ \\
\hline$O M$ & $\begin{array}{l}62,5 \% \\
\text { - Colangioma cístico } \\
(50 \%) \\
\text { - Adenoma } \\
\text { hepatocelular }(62,5 \%)\end{array}$ & $\begin{array}{l}62,5 \% \\
\text { - Carcinoma } \\
\text { hepatocelular padrão } \\
\text { trabecular }(37,5 \%) \\
\text { - Carcinoma } \\
\text { hepatocelular padrão } \\
\text { glandular }(25,0 \%)\end{array}$ & $\begin{array}{l}\text { - Colangiofibrose } \\
(12,5 \%) \\
\text { - Peliose }(37,5 \%)\end{array}$ \\
\hline$\beta C$ & $\begin{array}{l}75 \% \\
\text { - Colangioma cístico } \\
(50 \%) \\
\text { - Adenoma } \\
\text { hepatocelular }(50 \%) \\
\end{array}$ & $\begin{array}{l}25,0 \% \\
\text { - Carcinoma } \\
\text { hepatocelular padrão } \\
\text { trabecular }(25,0 \%)\end{array}$ & $\begin{array}{l}\text { - Colangiofibrose (25\%) } \\
\text { - Peliose }(25 \%) \\
\text { - Espongiose }(37,5 \%)\end{array}$ \\
\hline VA & $\begin{array}{l}37,5 \% \\
\text { - Colangioma cístico } \\
(25 \%) \\
\text { - Adenoma } \\
\text { hepatocelular }(25 \%)\end{array}$ & $\begin{array}{l}25,0 \% \\
\text { - Carcinoma } \\
\text { hepatocelular padrāo } \\
\text { trabecular }(25,0 \%)\end{array}$ & $\begin{array}{l}\text { - Colangiofibrose } \\
(12,5 \%) \\
\text { - Espongiose }(50 \%)\end{array}$ \\
\hline
\end{tabular}

Observa-se no Quadro 1 que o grupo de animais tratados com $\beta$-caroteno (grupo $\beta C$ ) por 8 semanas consecutivas e sacrificados na 48 a semana do experimento, ou seja, na fase de progressão da hepatocarcinogênese, apresentou maior incidência (75\%) de lesōes hepáticas benignas do que o grupo de ratos tratados com óleo de milho durante o mesmo periodo $(62,5 \%$ ) (grupo OM - controles). Todavia, constata-se ainda nesse Quadro, que a incidência de colangioma cistico foi idêntica (50\%) nesses dois grupos experimentais, e que ratos tratados com o carotenoide (grupo $\beta C$ ) apresentaram menor incidência $(50 \%$ ) de adenoma hepatocelular do que animais tratados com óleo de milho (62,5\%) (grupo OM).

Observou-se também menor incidência (25\%) de peliose no grupo $\beta C$ do que no grupo OM $(37,5 \%)$, embora o grupo de animais tatados com $\beta$-caroteno (grupo $\beta C$ ) tenha apresentado maior incidência (25\%) de colangiofibrose do que o grupo de ratos aos quais se administrou apenas óleo de milho (12,5\%) (grupo OM). Além disso, a incidência de espongiose foi de $37,5 \%$ no grupo $\beta C$, não tendo sido observada esta lesão hepática no grupo OM.

Por outro lado, constata-se também no Quadro 1 que a incidência de carcinomas foi menor $(25,0 \%)$ no grupo de ratos tratados por 8 semanas consecutivas com $\beta$-caroteno (grupo 
BC) e sacrificados 12 meses após aplicaçăo do carcinogênico iniciante DEN, do que no grupo controle $(62,5 \%)$ (grupo OM).

Resultados semelhantes a estes foram também observados em animais tratados com vitaminà A.

Assim, ainda de acordo com o Quadro 1, constata-se que o grupo de ratos que recebeu

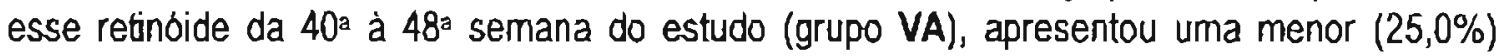
incidência de carcinomas do que o grupo controle $(62,5 \%$ ) (grupo OM — controles).

Além disso, o grupo de ratos tratados com a vitamina A por 8 semanas consecutivas durante a fase de progressão do modelo do RH (grupo VA) também apresentou menor $(37,5 \%)$ incidência de neoplasias benignas do que o grupo controle $(62,5 \%$ ) (grupo OM), incluindo estas lesỏes tanto o colangioma cistico como o adenoma hepatocelular. Por outro lado, observou-se incidência idêntica $(12,5 \%)$ de colangiofibrose nesses dois grupos experimentais. A incidência de espongiose observada no grupo VA correspondeu a $50 \%$, enquanto este tipo de lesão não foi constatado no figado dos animais do grupo controle (grupo OM).

\subsection{Avaliação das Concentraçóes Hepáticas de $\beta$-caroteno e Retinol}

A Tabela 4 apresenta os resultados relativos às concentraçōes hepáticas de $\beta$-caroteno e retinol (vitamina A) determinadas por cromatografia líquida de alta eficiência (CLAE), em figados de ratos Wistar submetidos ao modelo do "hepatócito resistente" e tratados da $40^{\text {a a }} 48^{\text {a }}$ semana do estudo com bleo de milho (grupo OM - controles), $\beta$-caroteno (grupo $\beta C$ ) ou vitamina $A$ (grupo VA), durante a fase de progressão da hepatocarcinogênese.

Tabela 4. Concentraçōes hepáticas de $\beta$-caroteno e retinol, de ratos Wistar submetidos ao modelo do "hepatócito resistente" e tratados com óleo de milho (grupo OM — controles), $\beta$-caroteno (grupo $\beta C$ ) ou vitamina A (grupo VA) por 8 semanas consecutivas, durante a fase de progressão da hepatocarcinogênese.

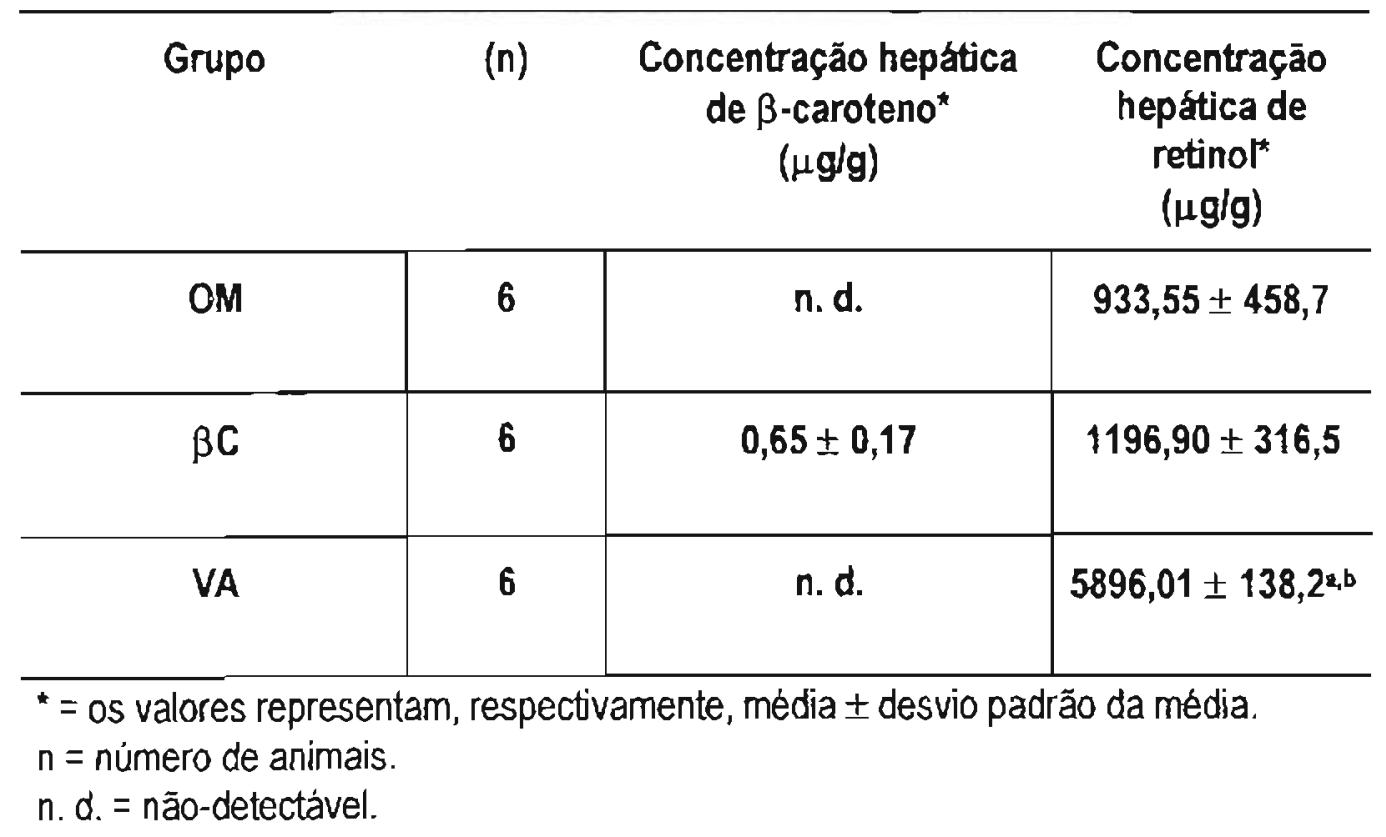


A significância $(p<0,05)$ entre as diferenças das médias foi determinada pelo teste de Mann Whitney para amostras não-pareadas:

$\mathrm{a}=$ diferente estatisticamente do grupo OM;

$b=$ diferente estatisticamente do grupo $\beta C$

Pode-se observar nessa Tabela que foram detectadas por cromatografia líquida de atta eficiência (CLAE), quantidades mensuráveis de $\beta$-caroteno no figado dos animais tratados com esse carotenóide por 8 semanas consecutivas e sacrificados 12 meses após aplicação da DEN (grupo $\beta C$ ), ao contrário do que ocorreu nos grupos OM (controles) e VA, e que contaram apenas com suas raçōes como única fonte de $\beta$-caroteno, durante esse mesmo periodo. Além disso, por ocasiāo do sacrificio ao término da $48^{\text {a }}$ semana do estudo, os ratos do grupo $\beta C$ tenderam a apresentar maiores concentrações hepáticas de retinol do que os animais do grupo controle (grupo OM), embora essa diferença nāo tenha alcançado, neste caso, significáncia do ponto de vista estatístico.

Por outro lado, observa-se ainda na Tabela 4 que animais tratados por 8 semanas consecutivas com vitamina A e sacrificados 12 meses após realizaçăo do processo de iniciação com a DEN (grupo VA), apresentaram concentrações hepáticas de retinol significantemente maiores $(p<0,05)$ do que os dois outros grupos experimentais, ou seja, do que o grupo OM (controles) e o grupo $\beta C$.

\subsection{Avaliação da Prolifferação Celular Hepática}

A quantificação da proliferação celular no figado pode ser realizada através de métodos bioquímicos que determinam as concentrações de DNA no tecido, ou métodos histológicos capazes de demonstrarem células que incorporaram no DNA de seus núcleos (indice de marcação) durante a sintese desse ácido nucléico, por exemplo, a base 5-bromo-2'-desoxiuridina (BrDU), um análogo da timidina (Figura 4).

Assim, a Tabela 5 demonstra os resultados das determinações das concentraçōes hepáticas de DNA realizadas através de método bioquímico, de animais submetidos ao modelo do "hepatócito resistente" e tratados com óleo de milho (grupo OM - controles), $\beta$-caroteno (grupo $B C$ ) ou vitamina A (grupo VA) por oito semanas consecutivas durante a fase de progressão da hepatocarcinogẽnese. 
Tabela 5. Concentrações hepáticas de DNA de animais submetidos ao modelo do "hepatócito resistente" e tratados com óleo de milho (grupo OM - controles), $\beta$-caroteno (grupo $\mathrm{BC}$ ) ou vitamina A (grupo VA) por 8 semanas consecutivas, durante a fase de progressão da hepatocarcinogênese.

\begin{tabular}{c|c|c}
\hline Grupos & $n$ & $\begin{array}{c}\text { Concentraçāo hepática } \\
\text { de DNA em mg/g* }\end{array}$ \\
\hline OM & 6 & $2,23 \pm 0,12$ \\
\hline$\beta C$ & 6 & $1,82 \pm 0,07 \mathrm{a}$ \\
\hline VA & 6 & $1,54 \pm 0,16^{2}$ \\
\hline
\end{tabular}

* = os valores representam, respectivamente, média \pm desvio padrāo da média.

$\mathrm{n}=$ número de animais.

A significância $(p<0,05)$ entre as diferenças das médias foi determinada pelo teste de Mann Whitney para amostras não-pareadas:

$a=$ diferente estatisticamente do grupo OM.

Pode-se observar na Tabela 5 que ratos submetidos ao modelo do RH e tratados com $\beta$-caroteno (grupo $\beta C$ ) ou vitamina $A$ (grupo VA) apresentaram menores $(p<0,05$ ) concentrações hepáticas de DNA do que seus respectivos controles (grupo OM), ou seja, do que aqueles animais tratados com óleo de milho e também sacrificados 12 meses após realização do processo de iniciaçāo com a DEN.

Já a Tabela 6 apresenta os resultados relativos ao indice de marcação com a BrDU, das áreas hepáticas consideradas "normais" ao redor das lesões pré-neoplásicas ou neoplásicas à macroscopia, bem como das próprias lesōes, de figados de animais submetidos ao modelo do "hepatócito resistente" e tratados durante 8 semanas consecutivas, com óleo de milho, $\beta$-caroteno ou vitamina $A$, em fase propicia ao desenvolvimento de cànceres. Além disso, pode-se ainda observar nessa Tabela, 0 valor relativo ao indice de marcaçāo de animais que não foram submetidos a esse modelo de hepatocarcinogênese ou a qualquer outro tipo de tratamento, mas que permaneceram na mesma sala em que ficaram os ratos dos outos grupos experimentais, até serem sacrificados ao término da $48^{\text {a }}$ semana do estudo. 
Tabela 6. Índice de marcação com a BrDU, de amostras de fígado de ratos normais (nenhum tratamento), bem como de áreas "normais" ao redor das lesões, e das próprias lesões, de animais submetidos ao modelo do "hepatócito resistente" e tratados com óleo de milho, $\beta$-caroteno ou vitamina $A$ por 8 semanas consecutivas, durante a fase de progressão da hepatocarcinogênese.

\begin{tabular}{c|c|c|c|c}
\hline Tratamento & $n$ & $\begin{array}{l}\text { Índice de marcação da } \\
\text { área unormal" ao } \\
\text { redor das lesōes" }\end{array}$ & $n$ & $\begin{array}{l}\text { Índice de marcaçāo das } \\
\text { lesões (nódulos persistentesl } \\
\text { cânceres) }^{*}\end{array}$ \\
\hline Nenhum & 4 & $0,03 \pm 0,05^{\mathrm{a}}$ & - & - \\
\hline Oleo de milho & 8 & $0,32 \pm 0,10$ & 7 & $2,87 \pm 1,8 \mathrm{~b}$ \\
\hline B-Caroteno & 8 & $0,11 \pm 0,08^{\mathrm{a}}$ & 7 & $1,05 \pm 1,1 \mathrm{a} . \mathrm{b}$ \\
\hline Vitamina A & 8 & $0,11 \pm 0,14^{\mathrm{a}}$ & 4 & $0,72 \pm 0,9$ \\
\hline
\end{tabular}

* = os valores representam, respectivamente, média \pm desvio padrâo da média.

$\mathrm{n}=$ número de animais.

A significância $(p<0,05)$ entre as diferenças das médias foi determinada pelo teste de Mann Whitney para amostras não-pareadas:

$a=$ diferente estatisticamente do grupo de animais tratados com óleo de milho;

$b=$ diferente estatisticamente do indice de marcação da respectiva área "normal" ao redor das lesões.

Pode-se constatar nessa Tabela que o índice de marcação com a BrDU da área considerada "normal" ao redor das lesões à macroscopia, de animais submetidos ao modelo do $\mathrm{RH}$ e tratados com óleo de miłho, foi maior $(p<0,05)$ do que o índice de marcação de animais não submetidos a esse modelo de hepatocarcinogênese ou a qualquer outro tratamento (nenhum tratamento). Além disso, observa-se tambem nessa Tabela 6 que os indices de marcação com a BrDU das áreas consideradas "normais" ao redor das lesões, de animais tratados com $\beta$-caroteno ou vitamina $A$ durante 8 semanas consecutivas em fase do modelo de hepatocarcinogênese propicia ao desenvolvimento de cânceres, foram menores $(p<0,05)$ do que o índice de marcação da área "normal" dos animais submetidos ao modelo do RH e tratados com óleo de milho da $40^{\mathrm{a}}$ à $48^{\mathrm{a}}$ semana do estudo.

Da mesma forma, constata-se ainda nessa Tabela que o indice de marcaçāo com a BrDU das áreas das lesões (nódulos persistentes/cânceres) de animais tratados com $\beta$-caroteno, foi menor $(p<0,05)$ do que o indice de marcação das áreas das lesōes do grupo de animais tratados com óleo de milho, sacrificados 12 meses após aplicação do carcinogênico iniciante DEN. Resultados semelhantes quanto ao indice de marcaçăo com a BrDU na área das lesões foram também observados em ratos tratados com a vitamina $A$, embora a diferença não tenha alcançado, neste caso, significància estatística quando em comparação ao indice de marcação da área das lesōes do grupo de animais submetidos ao modelo do $\mathrm{RH}$ e tratados com óleo de milho. 
Finalmente, pode-se ainda observar na Tabela 6 que os índices de marcação com a BrDU das áreas de lesões (nódulos persistentes/cânceres) foram maiores $(p<0,05)$ do que os indices de marcação das respectivas áreas consideradas "normais" ao redor das lesões à macroscopia, tanto no grupo de animais tratados com óleo de milho como no grupo de ratos tratados com (caroteno na fase de progressão do modelo do RH. Além disso, apesar de haver também uma tendência nesse sentido no grupo de animais tratados por 8 semanas consecutivas com vitamina A nessa etapa da hepatocarcinogênese, a diferença não atingiu, entretanto, neste caso, significância do ponto de vista estatistico (Tabela 6).

\subsection{Padrão de Metilação dos proto-oncogenes c-Ha-ras, c-myc, bem como do Gene que Codifica para a Enzima HMGCoA Redutase}

Para a avaliação do padrão de metilação dos proto-oncogenes c-Ha-ras e c-myc, bem como do gene que codifica para a enzima HMGCoA redutase, foram utilizadas amostras de figado coletadas de áreas consideradas "normais" ao exame Macroscópico, bem como de lesões pré-neoplásicas ou neoplásicas cuidadosamente separadas do tecido hepático circundante por ocasião do sacrificio, de ratos Wistar submetidos ao modelo do "hepatócito resistente" (RH) e tratados por 8 semanas consecutivas com óleo de milho (grupo OM - controles), $\beta$-caroteno (grupo BC) ou vitamina A (grupo VA), durante a fase de progressão da hepatocarcinogênese. Além disso, utilizou-se, nesse sentido, e para efeito de comparação, amostras de figado de ratos que não foram submetidos ao modelo do RH ou a quaisquer outros tratamentos (ratos normais) até a ocasião de seus sacrificios, também ao término da $48^{\text {a }}$ semana do estudo.

Após extração do DNA genômico dessas amostras, este foi digerido por 3 horas consecutivas com a enzima de restrição Hpa II ou Msp I. A seguir, analisou-se o padrão dos fragmentos resultantes, separados mediante eletroforese em gel de agarose e transferidos para membrana de nitrocelulose com suporte, empregando-se, por ocasião das hibridizações, sondas para os proto-oncogenes c-Ha-ras e c-myc, bem como para o gene que codifica para a enzima HMGCoA redutase.

Assim, as Figuras 6 e 7 demonstram o padrão de metilação do proto-oncogene c-Ha-ras do DNA extraido de amostras de figado de ratos normais, bem como de animais dos grupos OM (controles), $\beta C$ e VA sacrificados ao término da 48 a semana do estudo, digerido com a enzima de restrição Hpa II ou Msp I, respectivamente.

Pode-se constatar na Figura 6 que a digestão com a enzima de restrição Hpa II, do DNA extraido de amostras de figado de ratos não submetidos a quaisquer tratamentos (ratos normais), bem como de amostras de áreas consideradas "normais" ao exame macroscópico e de lesões hepáticas (nódulos persistentes/cânceres) de animais submetidos ao modelo do $\mathrm{RH} e$ tratados por 8 semanas consecutivas com óleo de milho (grupo OM - controles), $\beta$-caroteno (grupo $\beta C$ ) ou vitarnina $A$ (grupo VA) da $40^{\mathrm{a}}$ à $48^{\mathrm{a}}$ semana do estudo, resultou, basicamente, em seis fragmentos distintos marcados pela sonda para o proto-oncogene c-Ha-ras. Estes apresentavam uma distribuição por tamanho e intensidade de marcação pela sonda semelhante em todas as amostras, sendo dois maiores do que $23 \mathrm{~kb}$, dois apresentando tamanhos compreendidos entre 9,4 e $23 \mathrm{~kb}$, um entre 6,5 e 9,4 kb, e um com tamanho menor do que 2,0 kb. 
Figura 6. Digitalização de autorradiografia demonstrando padrões de fragmentos de restrição, dos DNAs extraídos de amostras de figado de ratos normais (colunas a e b), do tecido hepático ao redor de lesões (colunas $c_{1} d$ e e) e das próprias lesões hepáticas (nódulos persistentes/cânceres) de animais tratados com óleo de milho (colunas f [nódulo persistente], g e h [cânceres]), $\beta$-caroteno (colunas i [nódulo persistente], j e I [cânceres]) ou vitamina $\mathrm{A}$ (colunas $\mathrm{m}$ [nóduio persistente], $\mathrm{n}$ e o [cânceres]) durante a fase de progressão do modelo de hepatocarcinogênese do "hepatócito resistente", digeridos com a enzima Hpa II e hibridizados com sonda para o proto-oncogene c-Ha-ras.

Figura 7. Digitalização de autorradiografia demonstrando padrões de fragmentos de restrição, dos DNAs extraidos de amostras de figado de ratos normais (colunas a e b), do tecido hepático ao redor de lesões (colunas c, d e e) e das próprias lesões hepáticas (nódulos persistentes/cânceres) de animais tratados com óleo de milho (colunas $f$ [nódulo persistente], $g$ e $h$ [cânceres]), $\beta$-caroteno (colunas i [nódulo persistente], je I [cânceres]) ou vitamina A (colunas $m$ [nódulo persistente], $n$ e o [cânceres]) durante a fase de progressão do modelo de hepatocarcinogênese do "hepatócito resistente", digeridos com a enzima Msp I e hibridizados com sonda para o proto-oncogene c-Ha-ras. 


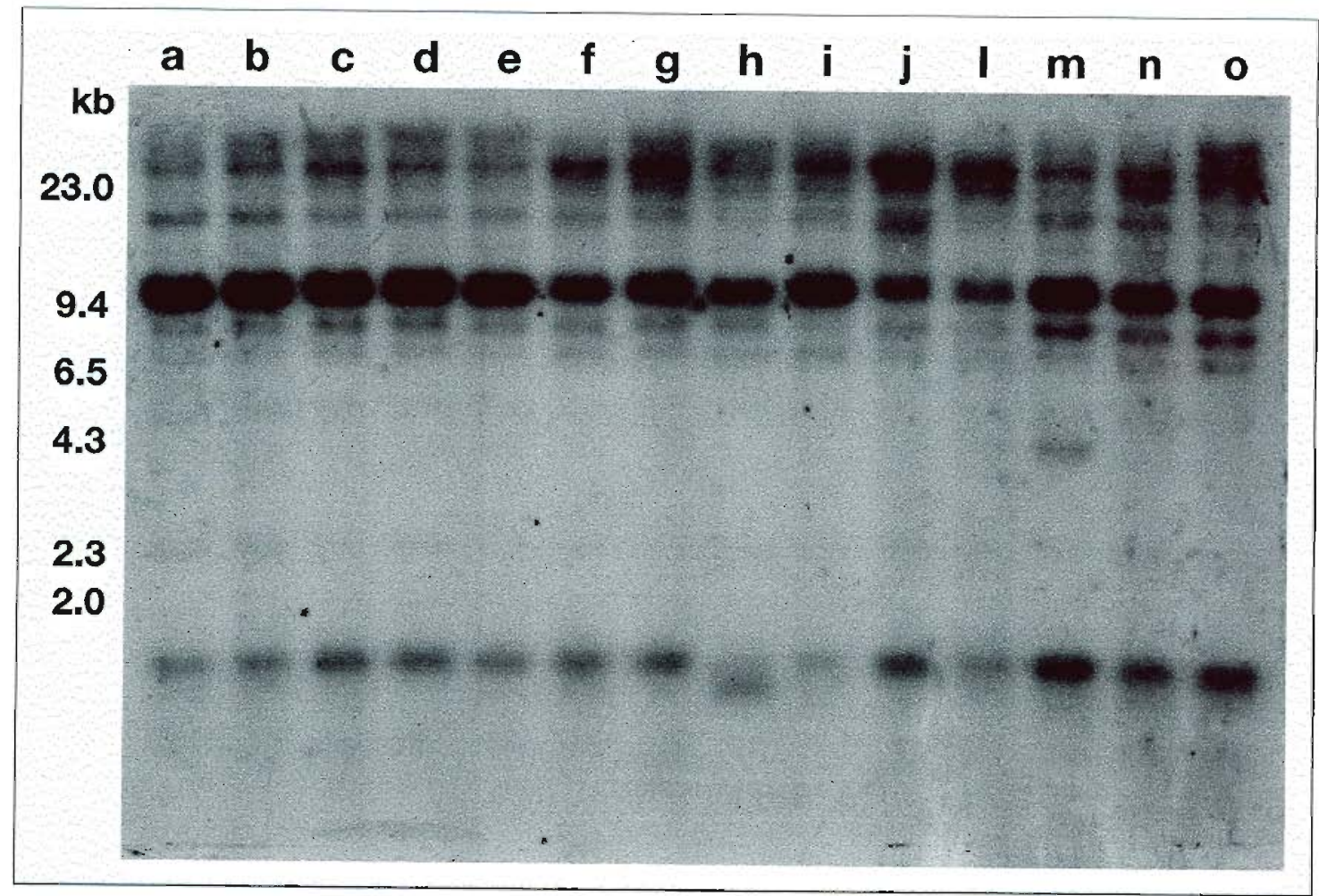

FIGURA 6

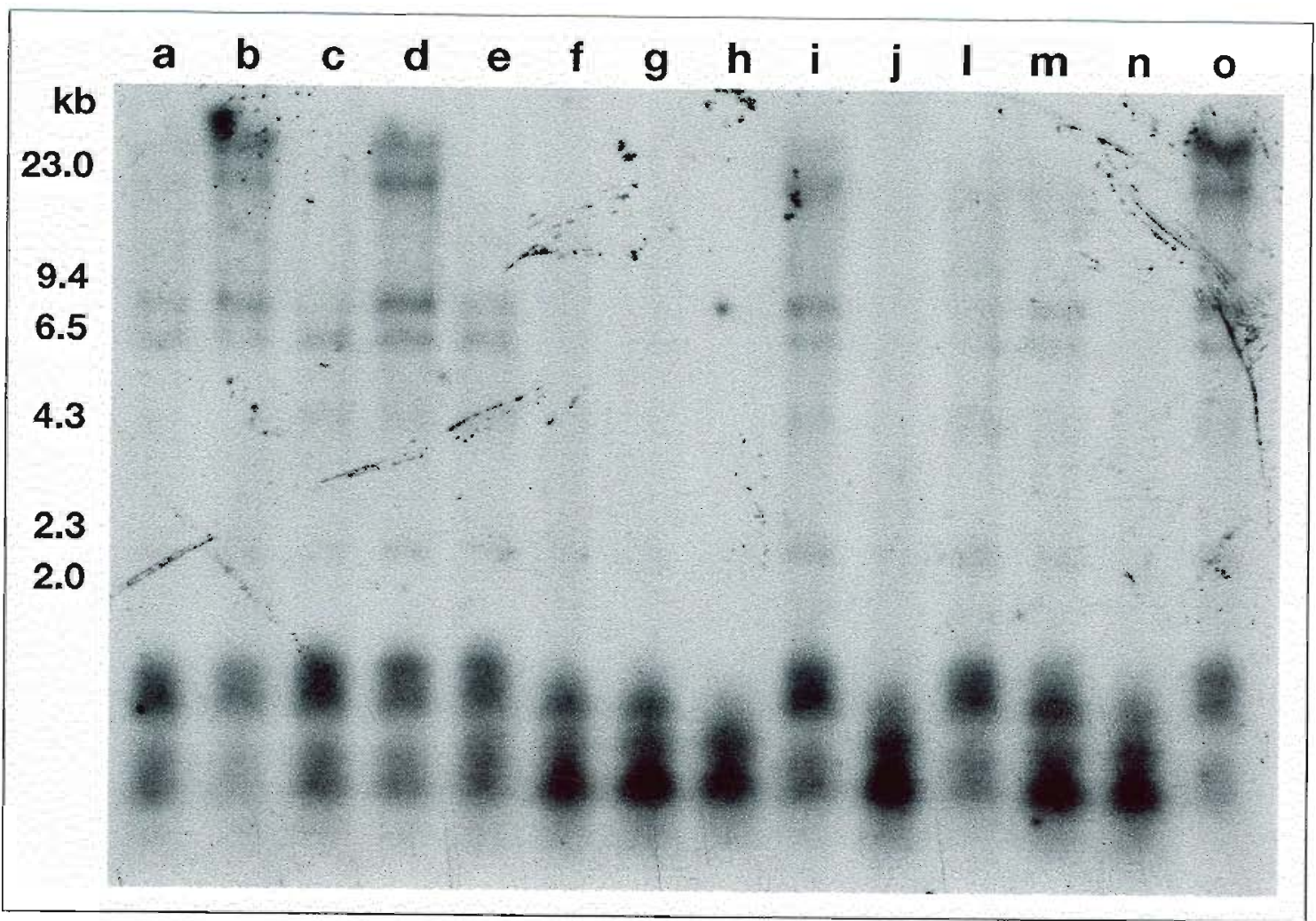

FIGURA 7 
Já na Figura 7 observazse que a digestāo com a enzima de restrição Msp I dessas mesmas amostras de DNA também resultou, nas amostras coletadas de figados de ratos não submetidos a quaisquer tratamentos (colunas a e b), bem como de áreas hepáticas obtidas dos tês outros grupos experimentais (grupos OM, $\beta C$ e VA) e consideradas "normais" à macroscopia (colunas c, d e e), em dez fragmentos distintos marcados pela sonda para o proto-oncogene c-Haras, sendo dois deles maiores do que $23 \mathrm{~kb}$, um apresentando tamanho compreendido entre 9,4 e $23 \mathrm{~kb}$, um com tamanho entre 6,5 e 9,4 kb, um entre 4,3 e 6,5 kb, um entre 2,0 e 2,3 kb e quatro fragrnentos menores do que $2,0 \mathrm{~kb}$, estes últimos marcados bem mais intensamente pela sonda.

Por outro lado, nas amostras de DNA extraido de lesões hepáticas (nódulo persistente e cânceres) de ratos submetidos ao modelo do RH e tratados com óleo de milho (grupo OM controles), a digestão com a enzima de restição Msp I resultou apenas em quatro fragmentos em duas delas (nódulo persistente e câncer; colunas f e g), um com tamanho compreendido entre 2,0 e $2,3 \mathrm{~kb}$ e três menores do que $2,0 \mathrm{~kb}$, bem como em tês bandas em uma das amostras (câncer; coluna h), uma delas com tamanho entre 2,0 e 2,3 kb e duas menores do que $2,0 \mathrm{~kb}$ (Figura 7). Nestas três amostras, as bandas menores do que 2,0 kb também se encontravam marcadas mais intensamente pela sonda para o proto-oncogene c-Ha-ras.

Este padrāo de metilação do proto-oncogene c-Ha-ras após digestão com a enzima de restrição Msp I do DNA extraido de amostras de lesões hepáticas (nódulo persistente e cânceres) do grupo OM (controles) foi também observado em uma amostra de DNA extraido de lesāo hepática (câncer) de animal submetido ao modelo de hepatocarcinogênese e tratado da $40^{\mathrm{a}}$ à $48^{\mathrm{a}}$ semana do estudo com $\beta$-caroteno (grupo $\beta \mathrm{C}$; coluna j) e em uma amostra (câncer) de rato tatado com vitamina A (grupo VA) (Figura 7; coluna n).

Em contraste, constatou-se em duas amostras de DNA extraido de lesōes hepáticas (nódulo persistente e câncer) coletadas de animais submetidos ao modelo do RH e tratados com $\beta$-caroteno (grupo $\beta C$; colunas i e I) durante fase desse modelo de hepatocarcinogênese propicia ao desenvolvimento de neoplasias malignas, bem como em duas amostras de DNA extraido de lesões hepáticas (nódulo persistente e câncer) de animais também submetidos ao modelo do $\mathrm{RH}$ e tatados com vitamina $\mathrm{A}$ (grupo VA; colunas $\mathrm{m}$ e o) durante a mesma fase do estudo, um padrăo de metilação do proto-oncogene c-Haras após digestão com a enzima Msp I, semelhante ao observado após digestão do DNA com essa mesma enzima de restriçāo, extraido a partir de amostras de figado de ratos não submetidos a quaisquer tratamentos (ratos normais; colunas a e b) ou de áreas consideradas "normais" à macroscopia (colunas c, d e e), colhidas de ratos submetidos ao modelo do $\mathrm{RH}$ (grupos $\mathrm{OM}, \beta C$ e VA) e também sacrificados ao término da 48a semana do estudo (Figura 7).

Procurando-se avaliar se foi suficiente para uma digestão adequada o periodo de 3 horas utulizado no presente estudo para a digestāo tanto com a enzima de restrição Hpa II como com a enzima MSp I, realizou-se um experimento em que se empregou DNA extraido de amosta de área hepática considerada "normal" ao exame macroscópico (Figura 8), de animal submetido ao modelo do "hepatócito resistente" e tratado com vitamina A (grupo VA), bem como DNA extraído de amostra de lesão pré-neoplásica (nódulo persistente) de rato submetido ao modelo do RH e tratado com $\beta$-caroteno (Figura 9), os quais foram digeridos com uma ou outra enzima de restriçāo por periodos que variaram de 1 a 6 horas, respectivamente.

A seguir, os fragmentos de DNA resultantes foram separados através de eletroforese em gel de agarose, tansferidos para membrana de nitrocelulose e hibridizados com sonda para o proto-oncogene c-Ha-ras, marcada com ${ }^{32 P}$.

Os resultados desse experimento estão apresentados nas Figuras 8 e 9. 
Figura 8. Digitalização de autonadiografia demonstrando padrōes de fragmentos de restrição, do DNA extraído de amostra de tecido ao redor de lesōes hepáticas de rato tratado com vitamina A durante a fase de progressão do modelo de hepatocarcinogênese do "hepatócito resistente", digerido por períodos que variaram de 1 a 6 horas com a enzima Hpa II ou Msp I e hibridizado com sonda para o proto-oncogene c-Ha-ras.

Figura 9. Digitalização de autorradiografia apresentando padrões de fragmentos de restrição, do DNA extraido de nódulo persistente de hepatócitos de rato tatado com $\beta$-caroteno durante a fase de progressāo do modelo de hepatocarcinogênese do "hepatócito resistente", digerido por periodos que variaram de 1 a 6 horas com a enzima Hpa II ou Msp I e hibridizado com sonda para o proto-oncogene c-Ha-ras. 


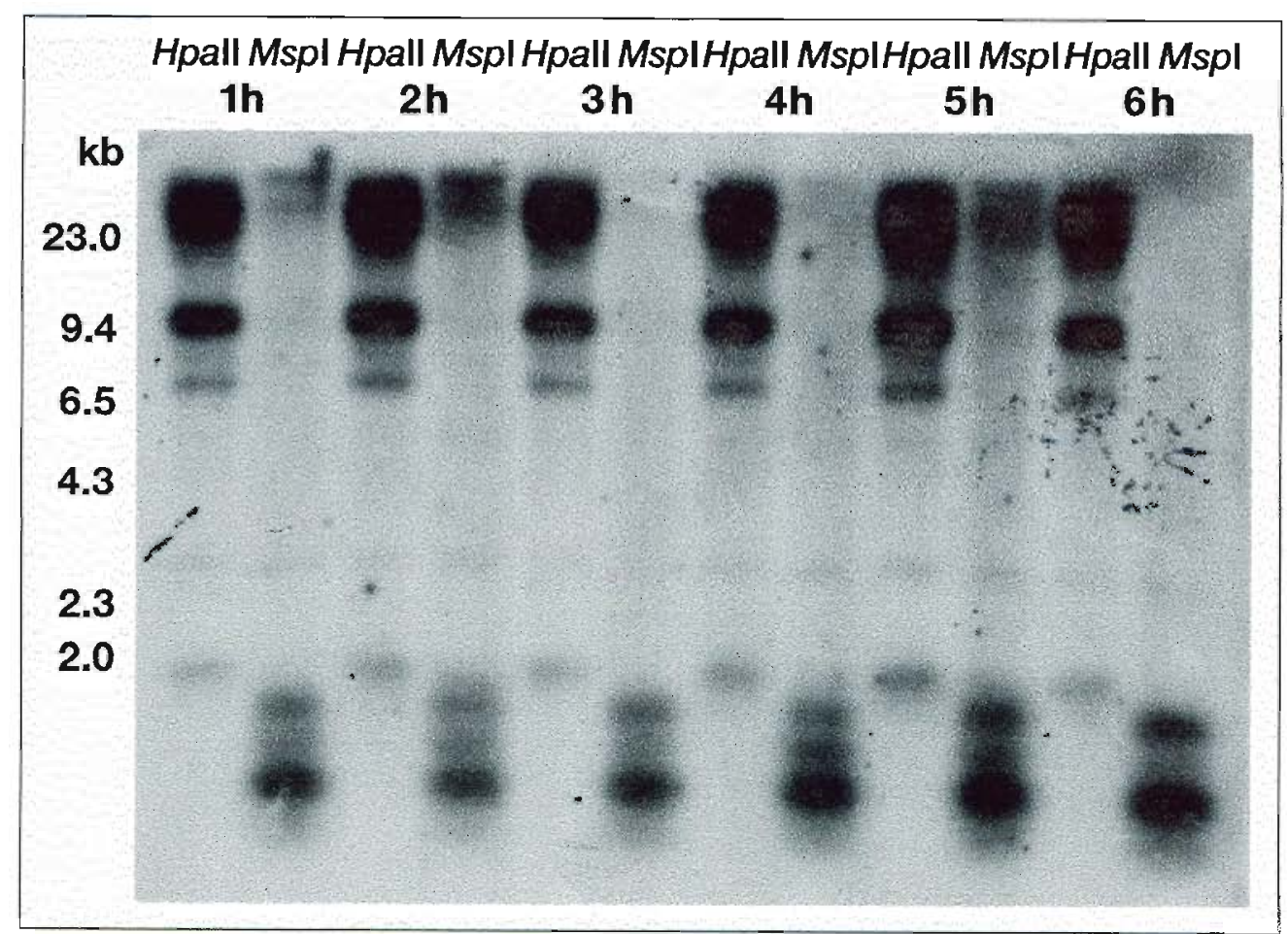

FIGURA 8

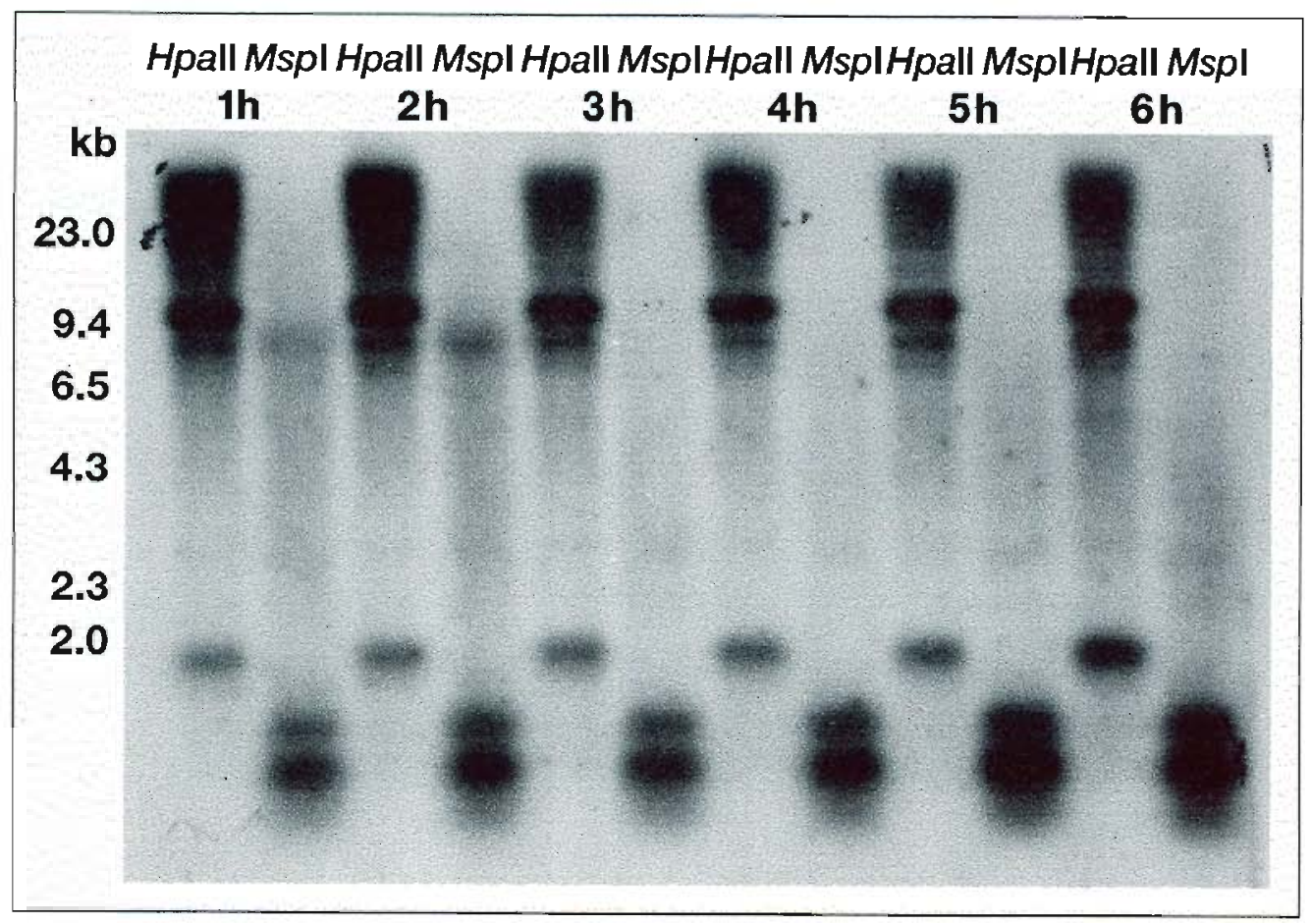

FIGURA 9 
Assim, pode-se observar nessas Figuras padrões de metilação do proto-oncogene c-Ha-ras após digestão com a enzima Hpa II ou Msp I semelhantes aos apresentados nas Figuras 6 e 7 após digestão com as mesmas enzimas, de amostras de DNA extraido de áreas hepáticas consideradas "normais" ao exame macroscópico, iem como de lesões hepáticas de animais submetidos ao modelo do RH e tratados com óleo de milho (grupo OM - controles), $\beta$-caroteno (grupo $\beta C$ ) ou vitamina A (grupo VA) da 40a à 48a semana do estudo. Além disso, pode-se ainda constatar nas Figuras 8 e 9 que os padrões de metilação do proto-oncogene c-Ha-ras foram praticamente os mesmos após os diversos periodos de digestão que variaram de 1 a 6 horas, tanto com a enzima de restrição Hpa II como com a enzima Msp I, respectivamente.

Após hibridização com a sonda para o proto-oncogene c-Ha-ras, as membranas de nitrocelulose com suporte contendo as amostras de DNA extraido de animais normais sacrificados ao término da 48a semana do estudo e de ratos em fase do modelo do RH propicia ao desenvolvimento de cânceres, e digerido com a enzima de restrição Hpa II (Figura 6) ou Msp I (Figura 7), foram, a seguir, lavadas e subsequentemente hibridizadas com a sonda para o proto-oncogene c-myc.

Os resultados dessas hibridizações encontram-se ilustrados nas Figuras de números 10 e 11.

Assim, pode-se observar na Figura 10, que a digestão com a enzima Hpa ll do DNA das amostras de figado colhidas de ratos não submetidos a quaisquer tratamentos (ratos normais), bem como de regiões hepáticas consideradas "normais" ao exame macroscópico de animais submetidos ao modelo do "hepatócito resistente" e sacrificados ao término da 48 a semana do estudo após tratamento por oito semanas consecutivas com óleo de milho (grupo OM controles), $\beta$-caroteno (grupo $B C$ ) ou vitamina $A$ (grupo VA), resultou, basicamente, em sete fragmentos (bandas) distintos de DNA marcados pela sonda para o proto-oncogene c-myc, sendo um deles maior do que $6,5 \mathrm{~kb}$, dois com tamanhos compreendidos entre 4,3 e 6,5 kb, dois com tamanhos entre 2,3 e 4,3 kb, e em dois fragmentos menores do que 2,0 kb. Estes últimos se apresentaram marcados bem menos intensamente pela sonda do que os cinco anteriores.

Por outro lado, pode-se ainda constatar nessa Figura 10 que a digestão com a enzima de restrição Hpa II, do DNA extraido de lesões hepáticas (nódulos persistentes e cânceres) colhidas de animais submetidos ao modelo do RH e sacrificados 12 meses após realização do processo de iniciação, independente do tratamento a que estes foram submetidos resultou apenas em quatro desses sete fragmentos, dois deles com tamanhos compreendidos entre $2,3 \mathrm{e}$ $4,3 \mathrm{~kb}$, e dois menores do que $2,0 \mathrm{~kb}$.

Além disso, pode-se observar na Figura 11 que a digestão agora com a enzima de restrição Msp I dessas mesmas amostras de DNA extraído de figado de ratos não submetidos a quaisquer tratamentos (ratos normais; colunas a e b) e de áreas consideradas "normais" ao exame macroscópico (colunas c, d e e), de animais submetidos ao modelo do "hepatócito resistente" e tratados durante a fase de progressão do modelo do RH com óleo de milho (grupo OM - controles), $\beta$-caroteno (grupo $\beta C$ ) ou vitarrina A (grupo VA), resultou em nove diferentes fragmentos marcados pela sonda para o proto-oncogene c-myc, sete deles com aproximadamente os mesmos tamanhos que os fragmentos resultantes da digestão com a enzima de restrição Hpa II dessas mesmas amostras de figado (Figura 10), e dois outros fragmentos com tamanhos compreendidos entre 2,0 e $2,3 \mathrm{~kb}$.

Por outo lado, a digestão com a enzima de restrição $M s p$ I do DNA extraido de lesões hepáticas, resultou em apenas uma banda marcada pela sonda para o proto-oncogene c-myc menor do que $2,0 \mathrm{~kb}$ em 3 amostras de lesões (nódulo persistente e cânceres) coletadas de animais submetidos ao modelo do RH e tratados com óleo de milho (grupo OM — controles; colunas f, $\mathrm{g} \mathrm{e} \mathrm{h}$ ) da 40a à 48 semana do estudo, bem como em uma amostra de lesão (câncer) obtida de animal 
tratado com $\beta$-caroteno (grupo $\beta C$; coluna j) e em uma amostra (câncer) coletada de rato tratado com vitamina A (grupo VA; coluna $n$ ), também durante essa mesma fase do estudo (Figura 11).

Além disso, em duas amostras de DNA extraido de lesões hepáticas (nódulo persistente e câncer) e digerido com a enzima de restrição $M s p l$, de animais submetidos ao modelc do $\mathrm{RH}$ e tratados com $\beta$-caroteno (grupo $\beta$ C; colunas i e I), bem como em duas amostras de DNA de lesões (nódulo persistente e câncer) coletadas de ratos também submetidos a esse modelo de hepatocarcinogênese mas tratados com vitamina A (grupo VA; colunas $m$ e o), constatou-se a presença de duas bandas menores do que $2,0 \mathrm{~kb}$ marcadas nitidamente pela sonda para o gene c-myc, bem como de dois outros fragmentos com tamanhos compreendidos entre 2,3 e 4,3 kb. Observou-se, ainda, nessas quatro amostras, a presença de um fragmento marcado tenuemente pela sonda, e com tamanho compreendido entre 2,0 e 2,3 kb (Figura 11).

Após as hibridizações com as sondas para os proto-oncogenes c-Ha-ras e c-myc, as membranas de nitrocelulose com suporte contendo as amostras de DNA extraido de animais normais e de ratos sacrificados em fase do modelo do $\mathrm{RH}$ propicia à constatação da presença de cânceres e digerido com as enzimas de restrição Hpa ll (Figuras 6 e 10, respectivamente) ou Msp I (Figuras 7 e 11, respectivamente), foram, a seguir, lavadas e subsequentemente hibridizadas com a sonda para o gene que codifica para a enzima HMGCoA redutase. 
Figura 10. Digitalização de autorradiografia demonstrando padrōes de fragmentos de restrição, dos DNAs extraidos de amostras de figado de ratos normais (colunas a e b), do tecido hepático ao redor de lesões (colunas $\mathbf{c}, \mathbf{d}$ e e) e das próprias lesões hepáticas (nódulos persistentes/cânceres) de animais tratados com óleo de milho (colunas f [nódulo persistente], g e h [cânceres]), $\beta$-caroteno (colunas i [nódulo persistente], j e I [cânceres]) ou vitamina $A$ (colunas $m$ [nódulo persistente], $n$ e o [cânceres]) durante a fase de progressão do modelo de hepatocarcinogênese do "hepatócito resistente", digeridos com a enzima Hpa II e hibridizados com sonda para o proto-oncogene c-myc.

Figura 11. Digitalização de autorradiografia demonstrando padrões de fragmentos de restrição, dos DNAs extraidos de amostras de figado de ratos normais (colunas a e b), do tecido hepático ao redor de lesões (colunas $\mathbf{c}, \mathbf{d}$ e e) e das próprias lesões hepáticas (nódulos persistentes/cânceres) de animais tratados com óleo de milho (colunas f [nódulo persistente], g e h [cânceres]), $\beta$-caroteno (colunas i (nódulo persistente], j e I [cânceres]) ou vitamina $A$ (colunas $m$ [nódulo persistente], $n$ e o [cânceres]) durante a fase de progressão do modelo de hepatocarcinogênese do "hepatócito resistente", digeridos com a enzima Msp I e hibridizados com sonda para o proto-oncogene c-myc. 


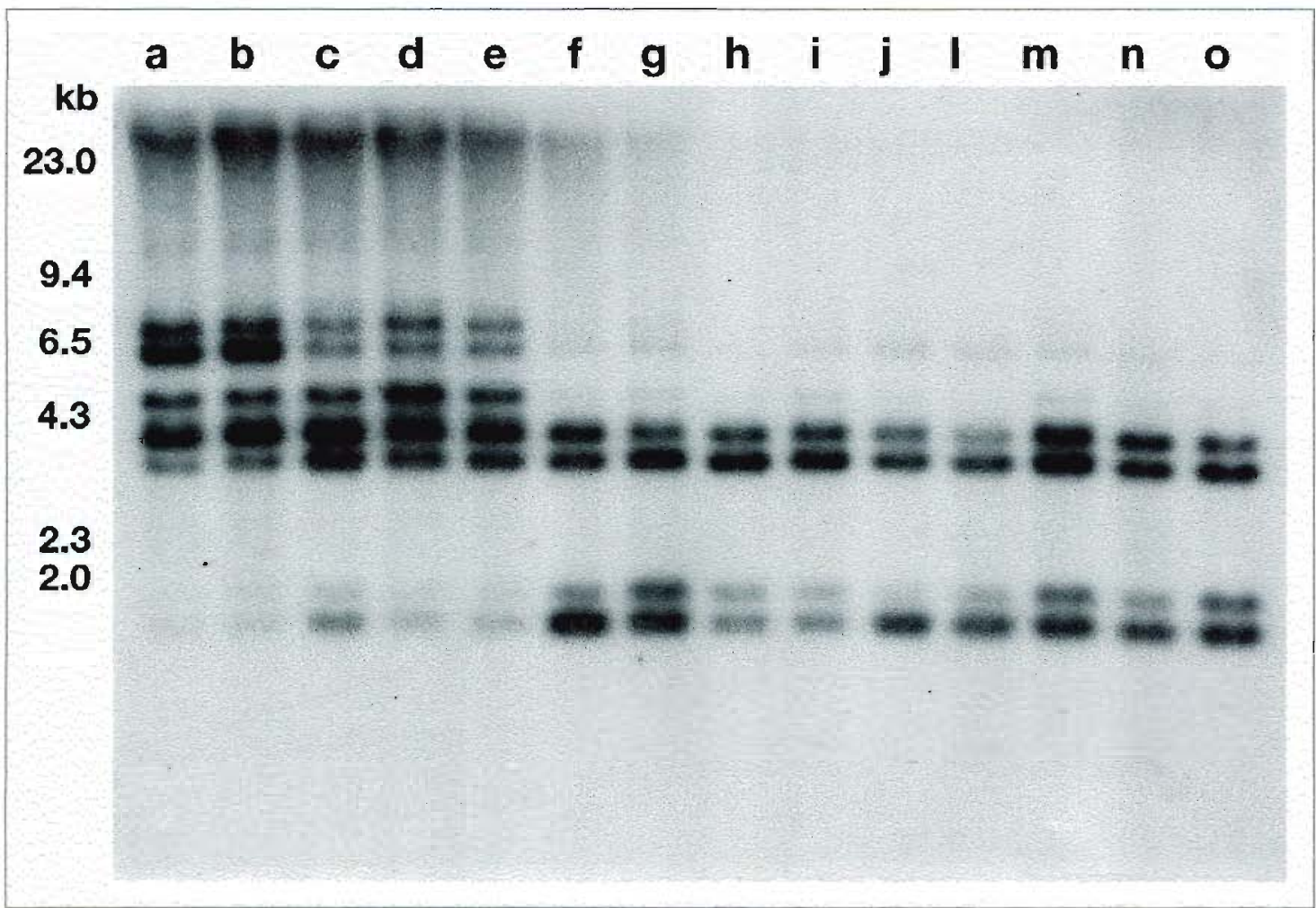

FIGURA 10

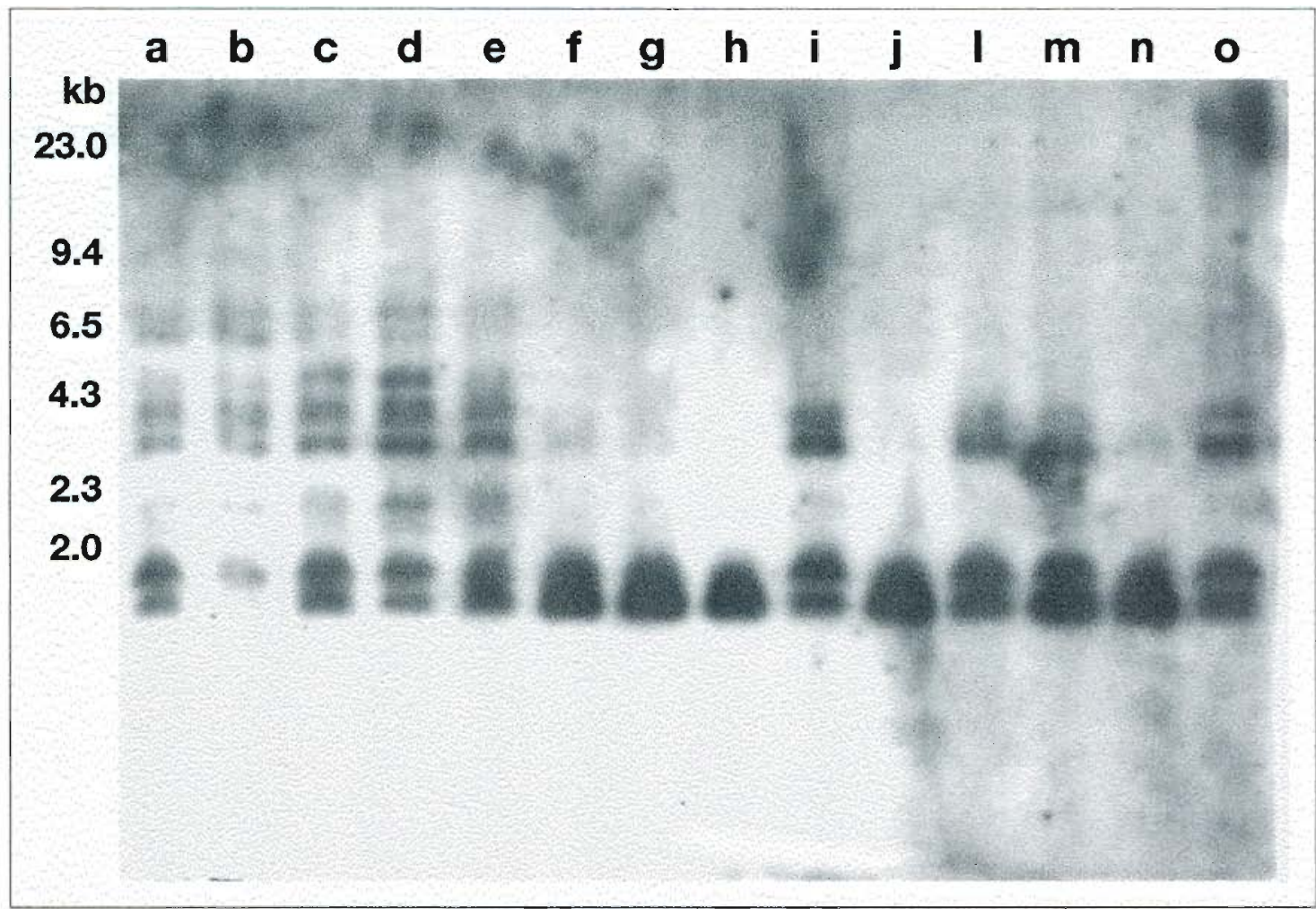

FIGURA 11 
Assim, as Figuras 12 e 13 demonstram o padrão de metilação do gene para a enzima HMGCoA redutase, após digestão com a enzima de restrição Hpa ll ou Msp I, respectivamente, do DNA extraido de amostras de figado coletadas de animais sacrificados ao término da $48^{\mathrm{a}}$ semana da estudo.

Pode-se observar na Figura 12 que a digestão com a enzima de restrição Hpa li, do DNA extraido de amostras colhidas de figados de ratos não submetidos a quaisquer tratamentos (ratos normais) e sacrificados ao término da $48^{a}$ semana do estudo, resultou, basicamente, em seis fragmentos marcados mais intensamente pela sonda para o gene da enzima HMGCoA redutase, um deles maior do que $23 \mathrm{~kb}$, tês com tamanhos compreendidos entre 9,4 e $23 \mathrm{~kb}$ e dois menores do que $2 \mathrm{~kb}$.

Além disso, a digestão com a enzima de restrição Hoa Il, do DNA extraído de áreas hepáticas consideradas "normais" à macroscopia, de animais submetidos ao modelo do "hepatócito resistente" e tratados por 8 semanas consecutivas com óleo de milho (grupo OM controles), $\beta$-caroteno (grupo $\beta C$ ) ou vitamina A (grupo VA), resultou, independentemente do tratamento a que estes foram submetidos, em oito fragmentos (bandas) marcados mais intensamente pela sonda para o gene que codifica para a enzima HMGCoA redutase, um deles maior do que $23 \mathrm{~kb}$, três com tamanhos compreendidos entre 9,4 e $23 \mathrm{~kb}$, dois entre 6,5 e 9,4 kb e dois menores do que $2 \mathrm{~kb}$ (Figura 12).

Por outro lado, a digestāo com a enzima de restriçāo Hpa II do DNA extraido de amostras de lesões hepáticas (nódulos persistentes e cânceres) de ratos submetidos ao modelo de hepatocarcinogênese e tatados com óleo de milho (grupo OM - controles), $\beta$-caroteno (grupo $\beta C$ ) ou vitamina $A$ (grupo VA) durante a fase de progressão do modelo do $\mathrm{RH}$, resultou, também independentemente do tratamento a que estes foram submefidos, em dez fragmentos distintos marcados pela sonda para o gene que codifica para a enzima HMGCoA redutase, sendo um deles maior do que $23 \mathrm{~kb}$, três com tamanhos compreendidos entre 9,4 e $23 \mathrm{~kb}$, dois entre 6,5 e 9,4 kb, dois entre 2,3 e 4,3 kb, um entre 2,0 e 2,3 kb e um bem menor do que 2,0 kb (Figura 12).

Já a digestão com a enzima de restrição Msp 1, do DNA extraído dessas mesma amostras de figado de um dos ratos nāo submetido a quaisquer tratamentos (rato normal; coluna a) e sacrificado ao término da $48^{\text {a }}$ semana do estudo, bem como de áreas hepáticas consideradas "normais" à macroscopia (colunas c, d e e), de animais submetidos ao modelo do RH e tratados com óleo de milho (grupo OM - controles), $\beta$-caroteno (grupo $\beta C$ ) ou vitamina A (grupo VA) por oito semanas consecutivas (Figura 13), resultou em onze fragmentos distintos marcados pela sonda para o gene da enzima HMGCOA redutase. Dez destes foram também constatados após digestāo com a enzima de restrição Hpa II, embora de amostras de DNA extraidas de lesões hepáticas (nódulos persistentes e cânceres) de animais submetidos ao modelo de hepatocarcinogênese e tratados com óleo de milho (grupo OM - controles), $\beta$-caroteno (grupo BC) ou vitamina A (grupo VA) da 40a à 48 semana do estudo (Figura 12), sendo a única exceçăo um fragmento com tamanho pouco menor do que $2,0 \mathrm{~kb}$.

Além disso, o padrāo de metilaçāo do gene que codifica para a enzima HMGCoA redutase após digestão com a enzima Msp I do DNA extraido de amostra de figado de um outro rato não submetido a quaisquer tratamentos e sacrificado ao término da 48 a semana do estudo (coluna b), foi semelhante ao descrito acima para amostra de DNA digerida com essa enzima de restrição e extraída também de figado de rato normal sacrificado na mesma etapa do estudo, exceto pelo fato de não se constatar, neste caso, a presença da banda bem menor do que 2,0 kb (Figura 13). 
Figura 12. Digitalização de autorradiografia demonstrando padrões de fragmentos de restrição, dos DNAs extraidos de amostras de figado de ratos normais (colunas a e b), do tecido hepático ao redor de lesões (colunas c $\mathrm{d}$ e e) e das próprias lesões hepáticas (nódulos persistentes/cânceres) de animais tratados com óleo de milho (colunas f (nớulo persistente], $\mathbf{g}$ e $\mathbf{h}$ [cânceres]), $\beta$-caroteno (colunas i [nódulo persistente], j e I [cânceres]) ou vitamina $\mathrm{A}$ (colunas $\boldsymbol{m}$ [nódulo persistente], $\mathbf{n}$ e o [cânceres]) durante a fase de progressão do modelo de hepatocarcinogênese do "hepatócito resistente", digeridos com a enzima Hpa II e hibridizados com sonda para o gene que codifica para a enzima HMGCoA redutase.

Figura 13. Digitalização de autorradiografia demonstrando padróes de fragmentos de restrição, dos DNAs extraidos de amostras de figado de ratos normais (colunas a e b), do tecido hepático ao redor de lesões (colunas $\mathbf{c}$, $\mathbf{d}$ e e) e das próprias lesões hepáticas (nódulos persistentes/cânceres) de animais tratados com óleo de milho (colunas $f$ [nódulo persistente], $g$ e $\mathrm{h}$ [cânceres]), $\beta$-caroteno (colunas i [nódulo persistente], j e $\mathrm{l}$ [cânceres]) ou vitamina $\mathrm{A}$ (colunas $\mathrm{m}$ [nóơulo persistente], $\boldsymbol{n} \in \mathrm{o}$ [cânceres]) durante a fase de progressão do modelo de hepatocarcinogênese do "hepatócito resistente", digeridos com a enzima Msp I e hibridizados com sonda para o gene que codifica para a enzima HMGCOA redutase. 


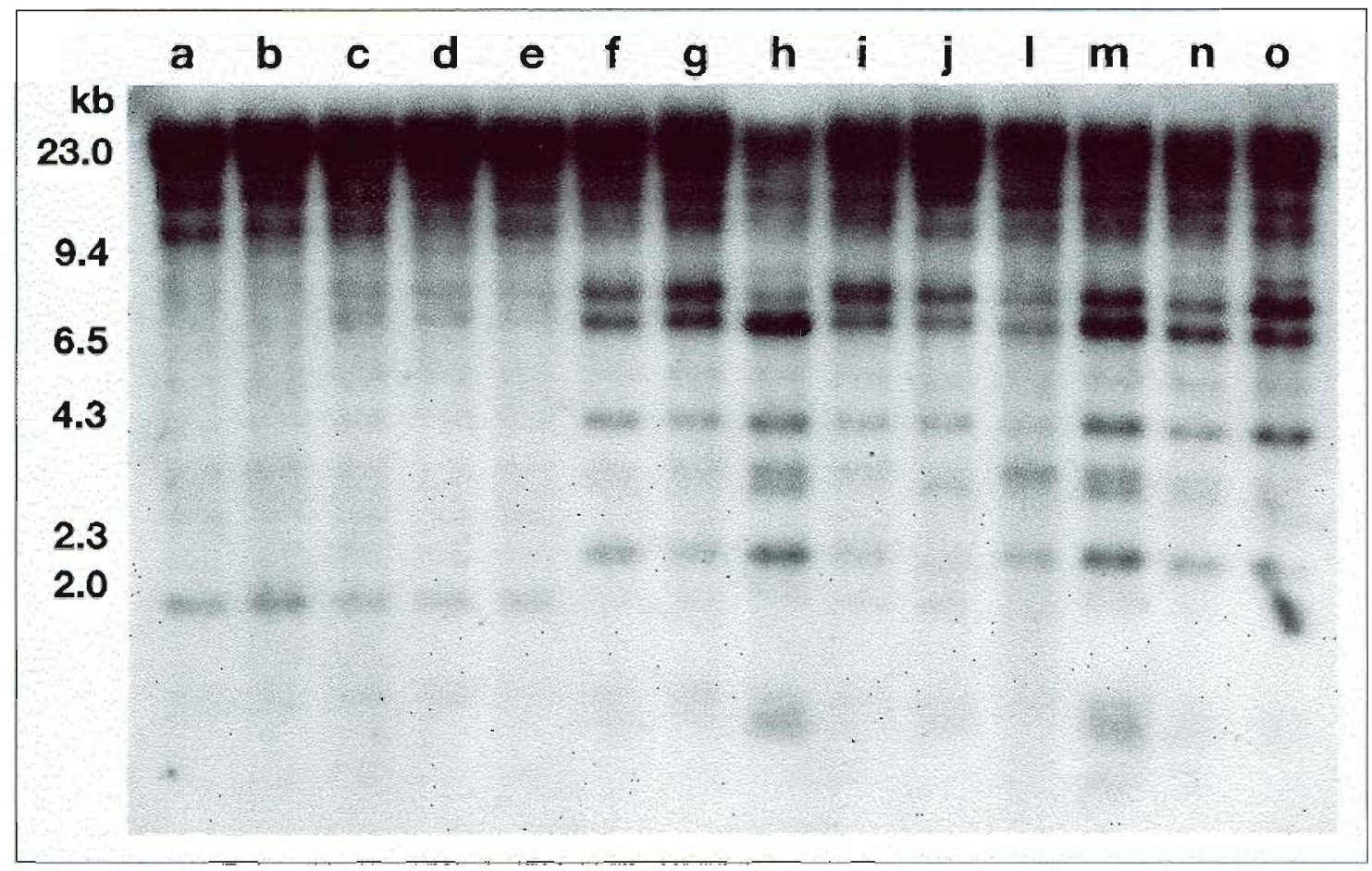

FIGURA 12

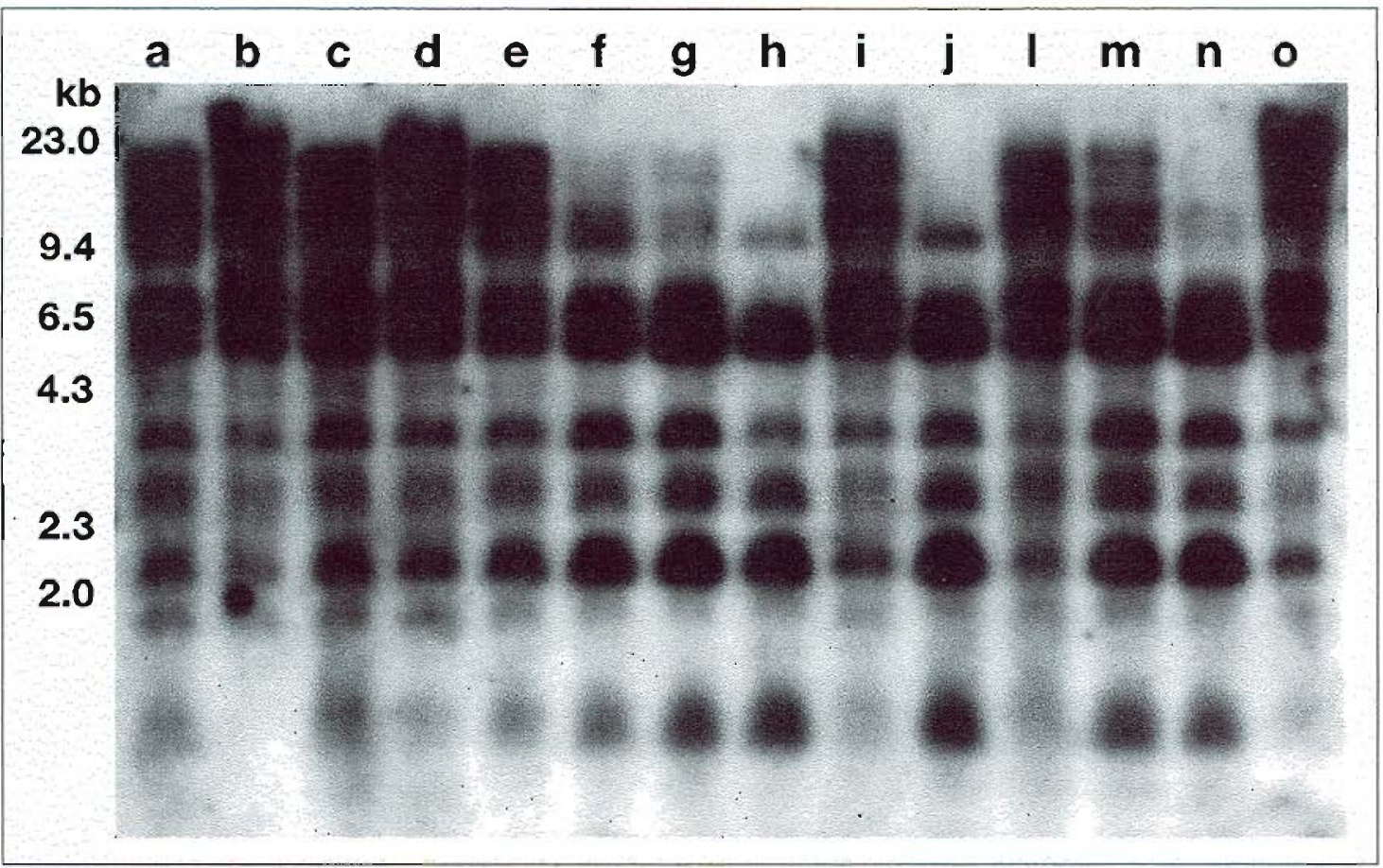

FIGURA 13 
Pode-se ainda observar na Figura 13 que em duas amostras de DNA extraido de lesões hepáticas (nódulo persistente e câncer) e digerido com a enzima de restrição Msp I, de animais submetidos ao modelo do RH e tratados com $\beta$-caroteno (grupo $\beta C$; colunas i e l) durante fase desse modelo propicia ao desenvolvimento de cânceres, bem como em 2 amostras de DNA extraido de lesões hepáticas (nódulo persistente e câncer) de ratos também submetidos a esse modelo de hepatocarcinogênese mas tratados com vitamina A (grupo VA; colunas $m$ e o), 0 padrão de metilação do gene que codifica para a enzima HMGCoA redutase foi praticamente idèntico ao observado após digestão com a enzima Msp l, do DNA extraído de amostras de figado de rato não submetido a quaisquer tratamentos (rato normal), bem como de amostras de áreas hepáticas consideradas "nomais" ao exame macroscópico, de animais submetidos ao modelo do RH e sacrificados 12 meses após aplicação do carcinogênico iniciante DEN.

Portanto, constata-se também nesses casos, a presença de 11 fragmentos distintos marcados pela sonda para o gene da HMGCoA redutase, variando em tamanho desde um fragmento maior do que $23 \mathrm{~kb}$ até um bem menor do que $2,0 \mathrm{~kb}$ (Figura 13).

Por outro lado, como se pode ainda observar na Figura 13, a digestão com a enzima Msp I do DNA extraído das três amostras de lesões hepáticas (nódulo persistente e cânceres) de animais submetidos ao modelo de hepatocarcinogênese e tratados com óleo de milho (grupo OM - controles; colunas $\mathrm{f}, \mathrm{g}$ e h) da 40 à 48a semana do estudo, bem como de uma amostra de lesão hepática (câncer) de animal também submetido ao modelo do RH e tratado com $\beta$-caroteno (grupo $\beta C$; coluna j) na mesma fase do estudo e de uma amostra de lesão hepática (câncer) de rato tratado com vitamina A (grupo VA; coluna $n$ ), resultou em um padrão de metlação do gene que codifica para a enzima HMGCOA redutase com os fragmentos de tamanho aproximado ou menores do que $9,4 \mathrm{~kb}$ marcados mais intensamente pela sonda, e com as bandas próximas a $23 \mathrm{~kb}$ marcadas de forma já bern mais tênue ou, inclusive, nāo-marcadas. 


\section{DISCUSSÃO}

Um dos intúitos básicos do presente estudo foi o de avaliar em ratos Wistar submetidos ao modelo do "hepatócito resistente" (RH), a existência de eventuais efeitos inibitórios em lesões pré-neoplásicas e neoplásicas por parte do $\beta$-caroteno ou da vitamina $A$, quando administrados especificamente durante a etapa de progressão da hepatocarcinogênese.

Para tanto, deu-se inicio às aplicações do carotenóide ou do retinóide na 40a semana após administraçăo do carcinogênico iniciante dietilnitrosamina (DEN) e que se estenderam por oito semanas consecutivas, quando então os animais foram sacrificados.

Não foram constatadas, nessa ocasião, diferenças estatisticamente significantes entre os pesos corpóreos dos ratos dos très grupos experimentais (grupos OM — controles; $B C$ e VA) (Tabela 1), o que sugere que os diferentes resultados relativos aos diversos parâmetros analisados no presente estudo e observados, eventualmente, tanto apos o tratamento com $\beta$ caroteno como com a vitamina $\mathrm{A}$, não devem ser atribuidos à ocorrência de alteraçôes no balanço calórico dos animais.

\subsection{Sobre a Quantificação à Macroscopia das Lesões Pré-neoplásicas e Neoplásicas Presentes nos Fígados de Ratos Wistar Submetidos ao Modelo do "Hepatócito Resistente" e Tratados com Oleo de Milho, $\beta$-Caroteno ou Vitamina A Durante a Fase de Progressāo da Hepatocarcinogênese.}

Tanto em seres humanos como em animais a ocorrência do câncer em muitos sitios é usualmente precedida pelo desenvolvimento de lesões proliferativas focais pré-neoplásicas, tais como papilomas, pólipos ou nódulos (FARBER, 1990).

No figado, da mesma forma que na maioria de outos tecidos e órgãos, pode-se observar um longo periodo de latência entre a exposição inicial a um carcinogênico químico apropriado, à radiaçāo ou a um DNA virus, e as primeiras evidências do câncer. Durante essa evolução prolongada, um achado constante tanto em roedores como em humanos é o aparecimento de proliferaçōes focais ou nódulos, compostos de hepatócitos e ductos biliares ocasionais (FARBER, 1990; SUGITANI et al, 1998).

Demostrou-se em diversos estudos, de forma convincente, que o hepatocarcinoma surge justamente no interior de tais nódulos de hepatócitos (FARBER, 1990).

Assim, baseado na evidência obtida a partir de diversos modelos de carcinogênese hepática no rato através da utilização de vários carcinogênicos químicos e promotores ou até mesmo de restriçăo de colina na ração (FARBER e SARMA, 1987; WU e MORENO, 1998), observou-se a ocorrência de um padrão de desenvolvimento do câncer hepático consistindo, basicamente, nas duas seguintes sequências fundamentais: (A) na gênese de proliferaçōes focais benignas de hepatócitos (focos e nódulos) provavelmente por expansão clonal, e das quais apenas uma pequena quantidade persiste, demonstrando proliferaçāo espontânea de hepatócitos mas sem outras evidências de neoplasia, incluindo o câncer; e (B) na evolução muito lenta de certa quantidade de proliferações focais persistentes de hepatócitos (nódulos persistentes de hepatócitos, "adenomas") através de um processo em múltiplas etapas na direção de um carcinoma hepałocelular com caracterlsticas citológicas e histoquímicas tipicas de malignidade, bem como com invasão e aparecimento de metástases (FARBER et al, 1988).

Em vários modelos de hepatocarcinogênese pode-se observar que essas duas sequèncias de evolução se sobrepõe, de modo que é praticamente impossivel a determinação 
de que etapa precede ou se segue a qualquer outra fase da carcinogênese (FARBER et al., 1988). Além disso, pode-se ainda constatar que as etapas essenciais dessas sequências são representadas pela indução inicial de um novo fenótipo (e também provavelmente um novo genótipo) em ừn raro hepatócito (iniciação), bem como pela expansão clonal subsequente dessas poucas células alteradas para produzirem proliferações focais benignas persistentes, ou seja, nódulos de hepatócitos (promoção). Portanto, a formaçāo dessas lesões no figado constitui um reflexo do desenvolvimento clássico da carcinogênese quimica através das etapas de iniciação e promoção (FARBER, 1984a; SARMA e FARBER, 1987; FARBER, 1990).

Nesse sentido, estima-se que no rato o processo de iniciação da hepatocarcinogênese com vários carcinogênicos quimicos esteja associado ao aparecimento constitutivo em um raro hepatócito (1 a cada $10^{5}-10^{6}$ hepatócitos), de um novo fenótipo denominado de resistência, com padrão bioquímico altamente característico. Este inclui pronunciadas reduçóes nas atividades de enzimas ou hemoproteínas (por exemplo citocromos P-450) que ativam carcinogênicos e outros xenobióticos (enzimas de fase l) e aumentos apreciáveis de atividades de enzimas (gama-glutamiltranspeptidase, glutationa-S-transferases) e outros componentes (glutationa) ativos na destoxificação (enzimas de fase II) (FARBER, 1984a; 1990; ROOMl et al., 1985; FARBER ef al., 1988).

O fenótipo dos hepatócitos iniciados nesse animal não inclui, por sua vez, qualquer grau mensurável de proliferação celular espontânea ou autônoma. Portanto, não ocorre expansão das células iniciadas individuais, até que seja criado um ambiente adequado graças a um regime de promoção (FARBER e RUBIN, 1991).

A única forma conhecida disto acontecer no figado do rato é proporcionando um estímulo geral à proliferação celular em que os hepatócitos iniciados são estimulados, ao mesmo tempo em que é inibida a proliferação de todos os outros hepatócitos normais, ou seja, atraves de um processo denominado de inibição diferencial (FARBER et al., 1988).

Esta consiste justamente na base do modelo de hepatocarcinogênese do "hepatócito resistente", em que o figado é estimulado a proliferar através de uma hepatectomia parcial ou por uma dose de algum agente necrogênico como o tetracloreto de carbono após a aplicação de um carcinogênico iniciante como a dietinitrosamina (DEN), ao mesmo tempo em que e exposto a carcinogênicos como o 2-acetilaminofluoreno (2-AAF), e que possibilitam que apenas os hepatócitos resistentes proliferem seletivamente para gerar nódulos (SOLT e FARBER, 1976; FARBER, 1984a; FARBER e RUBIN, 1991).

Descreve-se que o processo de iniciação ainda nesse modelo ocome de forma completa em aproximadamente 48 a 72 horas, enquanto a promoção se prolonga por cerca de 6 semanas. No caso de outros protocolos de hepatocarcinogênese, como por exempło do modelo do "ácido orótico" ou do "fenobarbita" (WU e MORENO, 1998), a inicação se dá durante o mesmo período de tempo, embora a promoção requeira cerca de 10 a 20 semanas (FARBER et al., 1988).

É interessante notar que o fenótio de resistência dos hepatócitos iniciados tem inúmeras sernelhanças com o fenótipo de células de alguns cânceres de seres humanos, quando estes se tornam resistentes a agentes quimioterápicos, graças também a uma maior expressão do gene mdr (FARBER e RUBIN, 1991).

Assim, durante a expansão clonal dos hepatócitos iniciados na direção da formação de nódulos pode-se observar, logo de início, o aparecimento de pequenas ilhotas microscópicas denominadas de focos distribuidas aleatoriamente pelo figado e sem relacionamento óbvio com qualquer zona do ácino ou lóbulo hepático. Em alguns modelos de hepatocarcinogênese estas expandem rapidamente através de proliferação celular, para gerar nódulos macroscópicos em alguns poucos dias ( 7 a 10 dias após aplicaçāo do 2-AAF, no caso do modelo do RH). Em outros, a expansão é lenta, durando várias semanas (FARBER, 1984a, 1984b). 
Estes focos são considerados "pré-neoplásicos", apesar de apenas alguns poucos (menos de $5 \%$ ) evoluirem para nódulos persistentes de hepatócitos e um menor número ainda estar relacionado, finalmente, ao câncer. Isto se deve a uma outra propriedade inerente aos focos e nódulos de hepatócitos, ou seja à capacidade que estes apresentam de sofrerem um processo denominado de remodelaçāo, ou seguirem, por sua vez, o caminho da persistência (TATEMATSU ef al., 1983; FARBER, 1984a; 1990; FARBER e RUBIN, 1991).

Não se sabe o motivo pelo qual focos e nódulos de hepatócitos adotam uma das duas opções, devendo estas corresponderem, entretanto, à expressão de alguma alteração incomum no genoma desencadeada por um carcinogênico durante o processo de iniciação (FARBER, 1984a; 1990; FARBER e RUBIN, 1991).

A remodelação está associada a alterações na bioquimica, arquitetura, organização e ultraestrutura dos focos e nódulos, de modo que estes se tornam muito semelhantes, senão idênticos, ao figado maduro normal, desaparecendo portanto. Por outro lado, a persistência de alguns poucos nódulos parece indicar um bloqueio nesse processo, surgindo a opçāo para a verdadeira evolução da sequência carcinogênica do nódulo para o câncer (FARBER, 1984a; 1990; FARBER e RUBIN, 1991).

Esta longa sequência, ou seja, a etapa assim chamada de progressão da hepatocarcinogênese contém, na verdade, as fases que são mais relevantes e ainda muito pouco conhecidas para o estabelecimento da malignidade, caracterizando-se pelo desenvolvimento de uma instabilidade genética nas celulas com consequente formação de subpopulações celulares neoplásicas heterogêneas (SARGENT et al., 1996).

Apesar de ainda praticamente desconhecida, tornou-se evidente no decorrer dos anos, entretanto, que a etapa de progressão pode ser modulada por exemplo através da alimentação ou por influências hormonais, que tendem a retardála ou inibi-la. Isto faz com que represente um segmento attativo do processo carcinogênico visando-se a quimioprevenção do câncer (FARBER e SARMA, 1987).

Durante a progressão, graças ainda ao processo de remodelação que também continua, ocorre subsequente redução no número de nódulos persistentes de hepatócitos, de tal forma que se costuma observar apenas cerca de 1-3 desses nodulos em todo o figado, quando se pode detectar concomitantemente um câncer de forma inequivoca, cerca de 10 a 12 meses após realizaçăo do processo de iniciação (FARBER e SARMA, 1987; FARBER ef al., 1988).

Descreve-se, ainda, que por ocasião da aplicação do modelo original do "hepatócito resistente" em ratos Fischer (F-344) machos, a breve exposição ao 2-AAF administrado na ração em concentraçōes variando de 0,015 a $0,05 \%$ é suficiente para promover o desenvolvimento de hepatocarcinomas em cerca de 70-90\% dos animais iniciados com os carcinogênicos DEN, N-metil-nitrosouréia (MNU), benzo[a]pireno (BP) ou dimefilhidrazina (DMH) (FARBER, 1984C; IMAl et al., 1997).

Apesar da administração crônica isolada do 2-AAF na ração poder iniciar hepatócitos e desencadear o desenvolvimento de cânceres no figado, deve ser enfatizado que a simples e rápida exposiçăo a essa substância nas condiçōes em que é empregada no modelo do RH original e sem a prévia aplicação de carcinogênicos, nāo è capaz de induzir à formação de hepatócitos resistentes e nem de hepatocarcinomas (FARBER e CAMERON, 1980; SOLT ef al., 1983; SEMPLE-ROBERTS ef al., 1987)

Quando o 2-AAF foj aplicado em ratos F-344 por intubação gástrica nas concentrações totais de 60 a $80 \mathrm{mg} / \mathrm{kg}$ de peso corpóreo distribuidos em 3-4 doses após a administração da DEN, por ocasião da tentativa de desenvolvimento de um modelo do "hepatócito resistente" modificado que evitasse as restrições legais impostas à adição de carcinogênicos nas raçōes 
em diversos paises desenvolvidos, constatou-se, entretanto, incidências de cânceres que variaram de 50 a $71 \%$ (SEMPLE-ROBERTS ef al., 1987).

No presente estudo a incidência de câncer observada ao exame macroscópico do figado por ocasião do sacrificio do grupo de ratos Wistar machos submetidos ao modelo do "hepatócito resistente ${ }^{p}$ e tratados com óleo de milho por oito semanas consecutivas durante a fase de progressão da hepatocarcinogênese (grupo OM - controles) correspondeu a 62,5\% (Tabela 2). Além disso, constatou-se ainda em cinco dos oito animais desse grupo um total de 26 nódulos persistentes de hepatócitos, ou seja, em média cerca de 5 dessas lesões proliferativas persistentes por rato.

Tais resultados estão de acordo, portanto, com evidências anteriormente descritas na literatura por ocasião da aplicação do modelo do "hepatócito resistente" modificado em ratos F-344 (SEMPLE-ROBERTS ef al., 1987), embora no atual experimento a incidência de cânceres constatada no grupo OM (controles) tenha sido pouco menor do que a observada em investigaçoes conduzidas tambem com ratos da linhagem Fischer (F-344) submetidos ao modelo do RH original e que utiliza, portanto, o 2-AAF adicionado à ração dos animais.

Esta diferença talvez possa ser atribuida à forma de adminisłação do 2-AAF (por intubação gástrica), ou à maior resistência que ratos Wistar apresentam reconhecidamente por ocasião da aplicação desse protocolo de hepatocarcinogênese (IRVING, 1975; FARBER et al., 1976), fato este que logo de inicio se procurou contomar quando da aplicação do modelo do RH modificado no presente estudo, mediante a ufilização de 2-AAF em grande dosagem total $(120 \mathrm{mg} / \mathrm{kg}$ de peso corpóreo distribuíoos em 6 doses iguais). Vale destacar que ratos dessa linhagem exibem ainda, caracteristicamente, uma reduzida tendência para a formação espontânea de hepatocarcinomas (SCHULTE-HERMANN, 1985).

Da mesma forma que em recentes experimentos conduzidos em condições praticamente idênticas (SILVEIRA, 1998), ficou, entretanto, aqui também clara a necessidade desse protocolo de hepatocarcinogênese ser melhor adaptado a ratos Wistar, visando-se a subsequente obtenção de maiores incidências de cânceres ao menos no grupo controle, o que sem dúvida facilitaria a interpretação de resultados de estudos em que se procura avaliar comparativamente a atividade quimiopreventiva ou terapêutica de substâncias.

Tais modificações poderiam incluir, como sugerido, um aumento da concentração ou da frequência de administração do 2-AAF, ou até mesmo a realização do sacrificio dos animais após periodo mais prolongado do que aos doze meses da realização do processo de iniciação (SILVEIRA, 1998).

Quando ratos Wistar foram submetidos ao modelo do $\mathrm{RH}$ e tratados com $\beta$-caroteno (grupo $B C$ ) ou vitamina $A$ (grupo VA) da 40 à $48^{\mathrm{a}}$ semana após aplicação do carcinogênico iniciante DEN, observou-se tamberm no atual estudo à macroscopia do figado quando do sacrificio dos animais, incidèncias de cânceres correspondendo a $25 \%$ nesses dois grupos experimentais (Tabela 2) e equivalendo, portanto, a incidências $60 \%$ menores do que a constatada no respectivo grupo controle $(62,5 \%$; grupo $0 \mathrm{M})$.

Além disso, ainda em comparaçăo ao grupo controle, observou-se também nessa ocasiāo que 0 grupo de animais aos quais se administrou o carotenóide (grupo $\beta C$ ) apresentou incidência pouco maior de nódulos de hepatócitos e praticamente o mesmo número dessas lesões pré-neoplásicas persistentes, ao contrário do grupo de ratos tratados com o retinóide (grupo VA), em que se constatou menor incidência e número total de nódulos persistentes.

Estes dados indicam, portanto, que o $\beta$-caroteno e a vitamina A apresentam efeitos inibitórios no desenvolvimento de lesões neoplásicas malignas quando administrados por 8 semanas consecutivas especificamente durante a fase de progressão da hepatocarcinogênese, e sugerem que esta atividade possa ocorrer, tanto no caso do carotenóide como do retinóide, por 
ocasião da conversão de nódulos persistentes de hepatócitos em cảnceres, enquanto apenas o retinóide é capaz de inibir a evolução dessas lesōes préneoplásicas ou fazer com que regridam.

Entende-se por conversão uma das etapas da carcinogênese que ocorre logo após a progressão pré-maligna e cujo conceito surgiu, basicamente, a partir de dados experimentais obtidos principalmente em modelos de carcinogènese hepática ou de pele e que demonstraram que a formação de neoplasias malignas poderia ser em muito aumentada através do tratamento de lesōes pré-neoplásicas com carcinogênicos de açāo direta, ou seja, genotóxicos (POTTER, 1981; HENNINGS et al., 1983; YUSPA, 1994; SARGENT et al., 1996). Assim, da mesma forma que a iniciação, a conversão maligna também parece envolver, provavelmente, eventos responsáveis pela produção de alteraçōes genéticas.

Acredita-se ainda que justamente a ocorrência de lesð̋es pré-neoplásicas como precursoras de diversos cânceres em seres humanos, como por exemplo leucoplaquias orais em fumantes e focos hiperplásicos do colo uterino, dê suporte à existência da etapa de conversão também no homem (DRAGSTED et al., 1993).

Apesar de praticamente não existirem referências na literatura a respeito de investigações em que também se procurou avaliar os eventuais efeitos inibitórios do $\beta$-caroteno quando administrado durante a fase de progressão da hepatocarcinogênese, resultados semelhantes aos do presente estudo foram relatados anos atrás, embora utilizando-se modelo de carcinogênese gástrica induzida em ratos pela $N$-metil- $N$-nitro- $N$-nitrosoguanidina (MNNG) diluida na água dos animais. Constatou-se, nesse caso, que o $\beta$-caroteno adicionado às raçōes foi capaz de inibir a progressão de displasias gástricas no sentido da evolução para carcinomas iniciais e infiltantes em $65 \%$ e $67 \%$, respectivamente, apesar de aumentar concomitantemente a formação das mesmas (SANTAMARIA et al., 1987).

Já mais recentemente, e também de acordo com os resultados do atual estudo, em experimentos condużdos em camundongos SENCAR fêmeas submetidos a modelo de carcinogênese de pele que empregava como agente iniciante 0 7,12-dimetilbenzla]antraceno (DMBA) e como promotor o acetato de 12-0-tetradecanoilforbol (TPA), observou-se que as administrações de ácido retinóico (a forma biologicamente mais ativa da vitamina A) em doses farMACologicas nas raçōes $(30 \mu \mathrm{g} / \mathrm{g})$, bem como de $\beta$-caroteno $(600 \mu \mathrm{g} / \mathrm{g})$, inibiram a conversāo de papilomas em carcinomas, aumentando entretanto a formação dessas lesões préneoplásicas benignas no caso do carotenóide, mas reduzindo seus números no caso do retinóide (CHEN ef al., 1993; DE LUCA ef al., 1993; 1994).

Todavia, constatou-se também posteriormente em um outro estudo conduzido em camundongos fêmeas embora da linhagem CD-1, que a administração oral de $\beta$-caroteno (200 mg/kg de peso corpóreo/dia) por intubação gástrica durante catore dias consecutivos foi capaz de reduzir o tamanho cumulativo de papilomas induzidos na pele através da aplicação de DMBA (KATSUMURA et al., 1996).

Apesar de não se ter aventado na ocasião qualquer mecanismo específico que pudesse explicar a major formação de papilomas após administração de $\beta$-caroteno em excesso na ração, a năo ser a maior necessidade que essas lesōes pré-neoplásicas eventualmente teriam de vitamina $A$, e que talvez esses papilomas correspondessem justamente a lesões pré-neoplásicas que não iriam softer, na verdade, conversão em carcinomas, sugeriu-se nesse caso que o carotenóide poderia estar atuando nesse processo graças à sua capacidade de transformação no organismo em ácido retinóico (CHEN et al., 1993).

Uma hipótese provável para explicar a ação do ácido retinóico na eficiência de conversão envolveria, por sua vez, a ativaçăo da expressão de receptores intranucleares para retinóides e consequente formação de complexos protéicos com proteinas de proto-oncogenes tais como c-fos, 
interferindo desse modo com suas ligações ao sitio do fator de transcrição AP-1 e prevenindo suas ações na conversão para a malignidade (DE LUCA et al., 1993; 1994).

Por outro lado, o ácido retinóico poderia também induzir a diferenciaçāo ou apoptose das células dos papilomas elou carcinomas, reduzindo a possibilidade de formação de lesões malignas visiveis (DE LUCA et al, 1994).

De qualquer modo, é provável que na verdade inúmeros mecanismos estejam envolvidos com a etapa de conversảo da carcinogènese (YUSPA, 1994), podendo, portanto, serem influenciados tanto por tratamentos com o $\beta$-caroteno como com a vitamina $A$.

Descreve-se que alguns destes mecanismos incluiriam não só os aumentos nas taxas de proliferação celular e de eventos mutacionais em genes como o c-Ha-ras e o 053 já observáveis, inclusive, durante a fase de progressāo pré-maligna, como também alteraçōes na expressão de genes do tipo c-fos, para proteases secretadas e para receptores presentes na superficie celular, incluindo integrinas (YUSPA, 1994).

Assim, poderiam ter aqui um papel de destaque as reconhecidas propriedades antimutagênicas do ß-caroteno (KRINSKY, 1993; AIDOO ef al., 1995; RENNER, 1995) que se relata serem capazes, inclusive, de prevenir o surgimento de alteraçōes cromossômicas (WEITBERG et al., 1985; STICH e DUNN, 1986; MUKHERJEE et al, 1991; SALVADORI et al., 1992; SARKAR et al., 1997).

Para meihor esclarecer os resultados do presente estudo e determinar mecanismos que pudessem estar a eles relacionados, seria talvez interessante que se procurasse avaliar no futuro, a existência de eventuais efeitos inibitórios do $\beta$-caroteno ou da vitamina A especificamente durante a fase de conversāo da hepatocarcinogênese, utilizando-se, para tanto, protocolo que consistisse em tês etapas distintas e incluisse a aplicação adicional de um agente progressor como a etilnitrosouréia, hidroxiuréia ou benzeno, capaz de produzir atteraçöes no genoma.

Tais protocolos já foram descritos para a indução da carcinogênese de pele em camundongos (HENNINGS et al., 1983) ou até mesmo da hepatocarcinogênese em ratos (DRAGAN et al., 1993), embora se acredite que no caso o próprio modelo do RH pudesse também ser adaptado nesse sentido.

Além dessas investigaçōes jà citadas, é relativamente pequeno o número de estudos relatados na literatura em que se procurou também avaliar os eventuais efeitos inibitórios do $\beta$-caroteno quando administrado durante a fase de progressão da carcinogènese.

Assim, descreveu-se em um outro experimento que também ứlizou modelo de carcinogênese de pele, que o carotenóide não foi capaz de inibir a conversão de papilomas em carcinomas, quando administrado nas raçöes de camundongos Skh na concentração de $30 \mathrm{mg} / \mathrm{g}$ (STEINEL e BAKER, 1990).

Da mesma forma, os resultados de uma investigação clinica demonstraram que a suplementação com $\beta$-caroteno durante 5 anos não foi capaz de prevenir a ocorrència de novos carcinomas de células basais ou de células escamosas, em pacientes previamente portadores de canceres de pele que não do tipo melanoma (GREENBERG et al., 1990).

Por outro lado, ainda de acordo com os dados do presente estudo, observou-se uma dirminuição no número de animais com carcinomas de pele apơs administração por 24 semanas consecutivas durante a fase de progressão, de $\beta$-caroteno na ração $(1 \mathrm{mg} / \mathrm{g}$ ) de camundongos submetidos a um modelo experimental em que a exposição dos animais a uma única dose de radiaçăo UV-B era suficiente para iniciar a carcinogenese (MATHEWS-ROTH e KRINSKY, 1987).

Além disso, descreveu-se também que o $\beta$-caroteno quando injetado localmente em sítios neoplásicos induzidos pelo carcinogênico DMBA foi capaz de causar a regressāo de carcinomas em 
bolsas faciais de "hamsters" (SCHWARTZ e SHKLAR, 1988; SCHWARTZ et al., 1991), da mesma forma que sua administraçāo oral em combinação com o alfa-tocoferol (SHKLAR et al., 1989).

Em um estudo em que as raçōes de camundongos SHN fêmeas susceptiveis ao desenvolvimento espontâneo ae neoplasisas malignas mamárias foram suplementadas com algas contendo elevadas concentraçōes de $\beta$-caroteno (Dunaliella bardawi), não se observou proteção no grupo de animais tratado do $1^{\circ}$ ao $4^{\circ}$ mês durante a etapa de iniciação da carcinogénese; entretanto, constatou-se efeitos inibitórios significantes no grupo tratado do $4^{\circ}$ ao 70 mês, ou seja, no decorrer tanto do processo de iniciação como de promoção, os quais foram ainda mais intensos no grupo tratado do $7^{\circ}$ ao $10^{\circ}$ mês durante a fase de progressão (NAGASAWA et al., 1991).

Assim, evidências nesse sentido publicadas até 1992 possibilitaram que se sugerisse em uma revisão, que o $\beta$-caroteno teria uma ação protetora mais pronunciada se administrado no decorrer da etapa de progressão da carcinogênese (ROUSSEAU et al., 1992).

Os resultados de uma investigação recente em que se constatou um menor número de carcinomas ductais in situ e invasivos após administração de $\beta$-caroteno na ração (25 ppm) especificamente durante a fase de progressão da carcinogênese pancreática induzida em "hamsters" pela aplicação de $\mathrm{N}$-nitrosobis(2-oxopropil)amina, estāo também de acordo, portanto, com essa sugestāo e de certa forma com os dados do presente estudo (MAJIMA et al., 1998).

Considera-se, por outro lado, que refinóides teriam uma ação predominantemente quimiopreventiva contra o câncer mas nāo quimioterapêutica, pois se observou que têm a capacidade de inibir principalmente a elapa de promoção da carcinogênese em diversos modelos experimentais e não suas etapas mais tardias, ou seja, a conversão e progressão (MUTO ef al., 1996).

Em se tratando da vitamina $A$, alguns poucos estudos tiveram também a oportunidade, entretanto, de constatar efeitos inibitórios quando de sua administração durante a etapa de progressão, especialmente em modelos de carcinogênese de mama e pâncreas em ratos, de pele em camundongos, bem como da bolsa facial em "hamsters" (MOON et al., 1994).

Da mesma forma, observou-se ainda em pacientes portadores de lesões cutâneas pré malignas que o tratamento com retinol (25.000 Ul/dia) resultou em uma redução significativa na incidência de carcinomas de células escamosas, em comparação ao grupo controle (MOON ef al., 1994).

Alèm disso, em um ensaio conduzido em 307 pacientes após ressecção de um câncer de pulmão de células não-pequenas em estadiamento grau I e que foram aleatoriamente distribuidos em dois grupos, constatou-se o desenvolvimento de novas neoplasias malignas primárias pulmonares em 29 individuos do grupo controle, enquanto isto ocorreu em apenas 18 daqueles tratados por um ano com paimitato de retinila (300.000 Ul/dia) (PASTORINO et al., 1993).

Portanto, os resultados do presente estudo em que se constatou menor incidencia de cânceres, bem como de nódulos persistentes de hepatócitos, em animais submetidos ao modelo do "hepatócito resistente" e tratados com vitamina A por oito semanas consecurivas durante a etapa de progressão da hepatocarcinogênese, estão de acordo com essas poucas evidências nesse sentido já descritas na literatura e confirmam, além disso, dados de outro estudo recentemente desenvolvido em nosso meio e realizado praticamente nas mesmas condições experimentais (SILVEIRA, 1998). 
6.2 Sobre a quantificação à microscopia das lesōes pré-neoplásicas e neoplásicas positivas para a $\gamma$ GT presentes nos figados de ratos Wistar submetidos ao modelo do "hepatócito resistente" e tratados com óleo de milho, $\beta$-caroteno ou vitamina A durante a fase de progressão da hepatocarcinogênese.

Os focos e nódulos de hepatócitos induzidos no figado de ratos expostos aos diferentes modelos de hepatocarcinogênese apresentam caracteristicamente diversas atteraçōes funcionais, 0 que possibilita que sejam facilmente evidenciados através da utilização de métodos histoquimicos e quantificados em sistemas computadorizados de análise de imagem. Nesse sentido, considera-se a reação de coloração positiva para a enzima gama-glutamiltranspeptidase (YGT) como um dos métodos mais úteis, sendo, portanto, amplamente utilizado até hoje em dia, pois cerca de 90-95\% dos focos e nódulos săo positivos para tal marcacior histoquímico em todas as etapas das fases préneoplásica e neoplásica da hepatocarcinogênese (FARBER, 1980; HANIGAN e PITOT, 1985).

A descoberta de uma associação entre a yGT e a carcinogênese hepática ocomeu pela primeira vez em 1972, quando se constatou concentrações elevadas dessa enzima nos figados de ratos expostos ao carcinogênico 3'-metil-4-dimetilaminoazobenzeno, bem como em hepatocarcinomas transplantáveis induzidos quimicamente em ratos (FIALA et al., 1972).

Posteriormente, utilizando-se um corante histoquímico para a yGT concluiu-se que as concentrações elevadas da enzima observadas durante a ingestão de carcinogênicos eram devidas a aumentos de atividade de yGT em focos de hepatócitos (KALENGAYl et al., 1975).

Investigaçōes subsequentes tiveram entăo a oportunidade de demonstrar a importância do aumento da atividade da enzima $\gamma$ GT como marcador de lesões pré-neoplásicas nos figados de ratos expostos a uma ampla variedade de carcinogênicos com estruturas químicas bastante diversas, incluindo a DEN, 2-AAF, $N$-nitrosomorfolina e aflatoxina $B 1$, bem como em neoplasias hepáticas de camundongos expostos ao safrol ou ao o-aminoazotolveno e em carcinomas hepatocelulares de seres humanos (HANIGAN e PITOT, 1985; YOUNGMAN e CAMPBELL, 1992; STARK et al., 1994).

A enzima yGT tem ampla distribuição tanto em tecidos vegetais como animais, constituindo uma glicoproteína com duas subunidades e que se liga à membrana plasmática das células com seu sifio ativo voltado para o exterior (HORIUCHI et al., 1978; HANIGAN e PTOT, 1985).

Em tecidos normais a atividade enzimática pode ser constatada principalmente em células que apresentam função secretória ou absortiva, sendo a yGT observada em maiores concentrações nos rins e, em seguida, no pâncreas e vesiculas seminlferas. Todos os outros tecidos apresentam menos de $1 \%$ da atividade constatada no rim, estando esta também presente no epitélio de ductos biliares e nas regiões das membranas dos hepatócitos voltadas para o canaliculo biliar (HANIGAN e PITOT, 1985; IWAl et al., 1994).

Concentraçōes anormalmente elevadas de yGT são frequentemente observadas, além disso, em neoplasias de uma variedade de tecidos tais como carcinomas hepatocelulares e da pele, adenocarcinomas de pulmão e em alguns cânceres de mama (HANIGAN e PITOT, 1985).

Descreve-se que a função fisiológica da yGT está intensamente associada ao metabolismo e transporte da glutationa (L- $\gamma$-glutamil-L-cisteinil-glicina), seu principal substrato, sendo a única protease conhecida capaz de clivar esse tripeptideo intacto e de utilizar, além disso, uma ampla variedade de compostos gama-glutamil como substratos, facilitando a transferência de seus grupamentos gama-glutamil para numerosos peptideos e aminoácidos aceptores (MEISTER, 1994). 
A glutationa está presente, por sua vez, em elevadas concentrações praticamente em todas as células de mamiferos onde representa cerca de $90 \%$ dos tióis não-protéicos e ciclando entre uma forma tiol reduzida (GSH) e uma oxidada (GSSG), em que dois tripeptideos se encontram ligados por uma ponte de dissulfeto.

Esta constitui, provavelmente, 0 antioxidante intracelular mais importante, tendo a capacidade de reagir com o peróxido de hidrogênio e outros peróxidos orgânicos e desempenhando um papel essencial na destoxificação de xenobióticos e carcinogênicos, bem como na proliferação celular (HENDRICH e PITOT, 1987).

Em 1973 foi proposta a existência de um ciclo "gama-glutamil" que seria responsável pelo transporte de aminoácidos e no qual a $\gamma$ GT desempenharia um papel fundamental transferindo o residuo gama-glutamil da glutationa a um aminoácido aceptor e transportando o dipeptideo gama-glutamil resultante através das membranas celulares (MEISTER, 1973).

Posteriormente questionou-se, entretanto, a validade dessa hipótese, sugerindo-se que pelo fato da glutationa não poder ser captada diretamente a partir do soro ou da urina pelas células em geral, o papel fisiológico significativo da $\gamma$ GT seria, na verdade, 0 de realizar a hidrólise da glutationa em seus aminoácidos constituintes que seriam então absorvidos (CURTHOYS e HUGHEY, 1979).

Mais especificamente no caso do hepatócito, a yGT presente em sua superficie poderia hidrolisar o grupamento gama-glutamil da glutationa existente no soro, fornecendo, dessa forma, os aminoácidos necessários à sintese intracelular de glutationa (HANIGAN e PITOT, 1985; ABBOTT e MEISTER, 1986).

Para uma célula proliferar são necessárias concentraçōes adequadas de glutationa. Portanto, a indução da yGT nos hepatócitos alterados durante a hepatocarcinogênese poderia possibilitar que estes utilizassem mais facilmente a glutationa extracelular, melhor preservando, dessa forma, suas próprias concentrações internas do tripeptideo (HANIGAN e PITOT, 1985; HENDRICH e PITOT, 1987).

Assim, hepatócitos com concentraçöes elevadas de $\gamma \mathrm{GT}$ teriam uma vantagem sobre os hepatócitos yGT-negativos, por ocasião da administração de compostos carcinogênicos ou promotores, que costumam depletar as concentrações intracelulares de glutationa. Isto implicaria que a $\gamma$ GT não seria apenas um marcador fenotipico de células pré-neoplásicas, mas sim uma enzima que proporcionaria uma vantagem seletiva à célula por ocasião do estresse imposto pelos protocolos de hepatocarcinogênese (HANIGAN e PITOT, 1985; HENDRICH e PITOT, 1987).

Em conformidade com essa hipótese demonstrou-se, já mais recentemente, que a elevação da atividade da yGT em nódulos de hepatócitos estava efetivamente correlacionada com a maior capacidade dessas estruturas removerem glutationa da circulação, sugerindo-se que esses fatores poderiam ser críticos para a maior resistência das lesões pré-neoplásicas observada em modelos de hepatocarcinogênese (CAMERON ef al., 1991).

De qualquer forma, a presença e o número de focos positivos para a $\gamma$ GT é geralmente considerada como um índice para hepatócitos alterados induzidos por carcinogênicos químicos durante o processo de iniciação da carcinogênese, tendo-se demonstrado que suas frequências dependem tanto da dose do carcinogênico iniciante como da duração com que este foi aplicado (EMMELOT e SCHERER, 1980).

Existem, entretanto, grandes discrepâncias entre o número de focos de hepatócitos que surgem logo de inicio no processo da carcinogênese e a recuperação final de neoplasias malignas, provavelmente devido ao processo de remodelação, bem como à instabilidade fenotipica dos mesmos. 
De acordo com seu aspecto à marcaçāo com a $\gamma \mathrm{GT}$, descreve-se que as lesões pré-neoplásicas podem ser classificadas em dois tipos, ou seja, em persistentes e em remodelação (ENOMOTO e FARBER, 1982; PASCALE et al., 1992).

Demonstrou-se que lesões do tpo persistente, marcadas uniformemente, foram vistas já às quatro semanas durante desenvolvimento do modelo do $\mathrm{RH}$, sendo que às 6 semanas cerca de $75 \%$ das lesōes encontravam-se em remodelação, mostrando irregularidade de contornos e perda da uniformidade na coloração. Esta perda era acompanhada por remodelação arquitetural para um figado de aspecto normal (ENOMOTO e FARBER, 1982).

Além disso, em uma investigação conduzida em ratos Wistar submetidos ao modelo do $\mathrm{RH}$ em que se procurou avaliar a cinéfica de evolução dos focos e nódulos de hepatócitos positivos para a yGT, observou-se que entre 4 a 9 semanas após a iniciação estes adentraram em uma fase de rápido crescimento, com subsequente diminuição progressiva de seus números e áreas, até que fossem observados apenas alguns poucos e em remodelaçāo, por ocasião do sacrificio na $26^{a}$ semana (GARCEA et al, 1989a).

Constatou-se no presente estudo por ocasião da quantificação das lesões pré-neoplásicas positivas para a yGT, que ratos da linhagem Wistar submetidos ao modelo do RH e tatados com bleo de milho (grupo OM - controles), $\beta$-caroteno (grupo $\beta C$ ) ou vitamina A (grupo VA) por oito semanas consecutivas durante a etapa de progressão da hepatocarcinogênese, apresentaram em seus figados praticamente o mesmo número médio de focosinódulos de hepatócitos quando de seus respectivos sacrificios na 48a semana após aplicação do carcinogénico iniciante DEN (Tabela 3).

Observou-se, ainda, que as áreas médias dessas lesões pré-neoplásicas, bem como as porcentagens de área do corte ocupadas pelas mesmas, também não diferiram entre si do ponto de vista estatistico, embora se constatasse certa tendência tanto por parte do tratamento com o carotenóide (grupo $\beta C$ ) como com o retinóide (grupo VA) em reduzi-las.

Assim, observa-se que nesses três grupos experimentais os números médios de focos/nódulos de hepatócitos positivos para a yGT por $\mathrm{cm}^{2}$ (Tabela 3) foram menores do que aqueles constatados em uma investigação anterior conduzida sob condições experimentais de certa forma semelhantes e também em grupos de ratos Wistar, embora nesse último caso estes

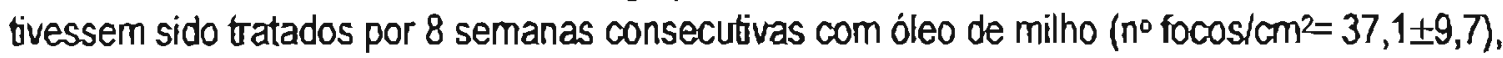
$\beta$-caroteno ( $n^{\circ}$ focos $/ \mathrm{cm}^{2}=20,1 \pm 12,5$ ) ou vitamina $A\left(n^{\circ}\right.$ focos $/ \mathrm{cm}^{2}=34,8 \pm 9,6$ ), respectivamente, durante as fases de iniciação e seleção/promoção do modelo do RH e sacrificados 6 semanas após administração da DEN (MORENO et al., 1995a).

Estes resultados do presente estudo estão, portanto, de acordo com evidências relatadas anteriormente na itheratura e que demonstram a ocorrência durante a evolução da hepatocarcinogênese para etapas mais tardias, de uma diminuição do número de focos/nódulos de hepatócitos posifivos para a yGT a partir de nove semanas da iniciação, graças em grande parte ao processo de remodelação (GARCEA et al., 1989a).

É questionável, entretanto, o verdadeiro papel que teriam no contexto geral da hepatocarcinogēnese estas poucas lesōes pré-neoplásicas yGT positivas obsenáveis à microscopia, remanescentes após um ano da aplicação da DEN e ainda observáveis em plena fase de progressão.

Talvez se trate daquelas lesōes focais que desde 0 inicio seriam benignas e assim continuariam, demonstrando proliferação espontânea de hepatócitos mas sem outras evidências de evoluçãa para neoplasias, incluindo o câncer (e que portanto se desenvolveriam de acordo com a assim denominada sequência $A$ de evolução) (FARBER et al., 1988), da mesma forma que o relatado para papilomas que a priori não seriam passiveis de sofrerem conversão e 
progredirem para a mafignidade, observados em modelo de carcinogênese de pele induzida em camundongos (SHUBIK, 1950; HENNINGS et al., 1985).

Por outro lado, pode ser que estas ainda possam vir a evoluir com o decorrer do tempo, pois apresentam condiçōes intrinsecas para tanto. Assim, observou-se que o catabolismo da glutationa pela yGT na presença de metais de transição pode iniciar por si só um processo oxidativo nos focos e nódulos pré-neoplásicos de hepatócitos, com subsequente produçåo de um ambiente rico em radicais livres e consequentes lesões oxidativas. Isto fez, portanto, com que se sugerisse que esses danos estimulados pela maior atividade da enzma $\gamma$ GT presente nos focos e nódulos de hepatócitos, poderiam vir a contibuir para com os processos através dos quais as células no interior dessas lesões progrediriam para a malignidade (HANIGAN e PITOT, 1985; STARK et al., 1994).

\subsection{Sobre os aspectos morfológicos e a quantificaçāo das lesōes hepáticas por ocasião da realização do exame histopatológico dos fígados de ratos Wistar submetidos ao modelo do "hepatócito resistente" e tratados com óleo de milho, $\beta$-caroteno ou vitamina A durante a fase de progressão da hepatocarcinogênese.}

Cortes histológicos corados atavés do método rotineiro de hematoxilina-eosina possibilitam que se realize no figado de ratos submetidos a modelos de hepatocarcinogênese, uma melhor caracterizaçąo morfológica dos tipos de hepatócitos alterados presentes em lesões pré-neoplásicas e neoplásicas, bem como a verificação da existência ou não de outtas alferaçōes no interior ou exterior das mesmas.

Embora não se tenha feito uma determinaçāo acurada de suas respectivas porcentagens, constatou-se no presente estudo por ocasião da realização da análise histopatológica do figado de ratos Wistar submetidos ao modelo do $\mathrm{RH}$ e tratados por oito semanas consecutivas com óleo de milho (grupo OM - controles), $\beta$-caroteno (grupo $\beta C$ ) ou vitamina A (grupo VA) durante a fase de progressāo da hepatocarcinogênese, que a maioria das lesões pré-neoplásicas correspondeu nos três grupos experimentais principalmente a focos e nodulos de hepatócitos assim denominados de células claras e mistos, embora pudessem ser também observados em menor quantidade os outros tipos de focos e nódulos, ou seja, os constituidos predominantemente por células acidófilas ou basófilas.

Acredita-se que os vários tjpos histológicos de focos e nódulos reflitam variações no metabolismo do glicogênio e na taxa de crescimento, exibindo os basofilicos o menor acúmulo desse carboidrato e a maior síntese de DNA em relaçāo às outas lesōes pré-neoplásicas, e estando estes, talvez, mais propensos à transformação cancerosa (ZERBAN et al., 1994).

Por outro lado, os focos constituídos predominanternente de células claras, que se apresentam com volume aumentado e com seu citoplasma rarefeito corando-se com pouca intensidade pela eosina e nas quais há acúmulo de glicogênio, sāo considerados os primeiros a surgirem na hepatocarcinogênese induzida por vários modelos, sendo também os que apresentariam características morfológicas menos agressivas. Já as lesões acidofilicas, mais agressivas e com células cujo citoplasma se cora mais intensamente pela eosina o que thes confere uma coloraçåo avermelhada uniforme, representariam uma etapa evolutiva na direção da malignidade. (MOORE et al., 1982; BANNASCH, 1984; BANNASCH e ZERBAN, 1990).

Tipos intermediários de lesōes pré-neoplásicas foram também identificados e contendo células claras e acidofilicas, podendo, portanto, serem designados como "focos/nódulos claro-eosinofilicos" (KRAUPP-GRASL et al., 1990). Considerou-se entretanto mais recentemente como mais apropriado 
para os mesmos o termo "focos mistos", por se acreditar que se tratem, na verdade, de uma espécie de transiçāo de uma lesāo pré-neoplásica para outra (DAGLI, 1994).

Desta forma, a análise das caracteristicas citológicas dos focos e nódulos de hepatócitos presentes no figado dos animais dos tês grupos experimentais (grupo OM - controles; $\beta \mathrm{C} \mathrm{e}$ VA) sacrificados 12 meses após realização do processo de iniciação indicou, no presente estudo, a existência de uma predominância de lesōes pré-neoplásicas consideradas menos agressivas, quais sejam as dos tipos histológicos constituídos principatmente por células claras e mistos. Esta revelou, ainda, que aparentemente o padrão de distribuição das mesmas não variou entre os três grupos experimentais, o que também sugere que tanto o tratamento com $\beta$-caroteno como com vitamina $A$ por oito semanas consecutivas na fase de progressão da hepatocarcinogênese, não tiveram influências dignas de nota nesse sentido e, portanto, nas reações metabólicas que poderiam determinar as caracteristicas histológicas dessas diversas lesões pré-neoplásicas (ZERBAN et al, 1994).

Estes resultados estão de acordo com os dados de uma investigação recente também conduzida em ratos Wistar submetidos ao modelo do RH e em condiçōes experimentais bastante semelhantes, em que se observou 12 meses após aplicaçāo do carcinogênico iniciante DEN, a presença em maior porcentagem de focos e nódulos mistos de hepatócitos no figado de animais tratados com óleo de milho ou vitamina $A$ por oito semanas consecutivas durante a fase de progressão da hepatocarcinogênese (SILVEIRA, 1998).

Estão ainda de acordo com as evidèncias de um outro estudo em que ratos dessa linhagem foram submetidos ao mesmo modelo de hepatocarcinogênese acrescido de promoção com fenobarbital por 16 semanas consecutivas, embora sacrificados 14 meses após realização do processo de iniciação. Constatou-se também nesse caso, a presença em maior porcentagem de focos e nódulos de hepatócitos morfologicamente menos agressivos, constituidos principalmente por células claras e acidofilicas, ao invés dos mais agressivos com predominância de células basofilicas (PASCALE et al., 1992).

Ainda nessa investigação observou-se, entretanto, que o tratamento dos animais com S-adenosil-L-metionina (SAM), um composto lipotrópico doador de grupamentos metila, apesar de também não modificar os padrões histológicos dos nodulos de hepatócitos reduziu, no decorter do tempo, a porcentagem dos basofilicos, bem como a incidência de hepatocarcinomas (PASCALE et al., 1992).

Seria interessante, portanto, que por ocasião da realização de experimentos futuros se procurasse avaliar de forma mais detalhada no decorrer da hepatocarcinogênese, uma eventual ação inibitória tanto por parte do $\beta$-caroteno como da vitamina $A$ mais especificamente em relaçăo aos focosinódulos basofilicos, os quais são amplamente reconhecidos na literatura como representantes de uma préetapa imediata no desenvolvimento dos carcinomas hepatocelulares (BANNASCH e ZERBAN, 1990).

No presente estudo, o exame histopatológico detalhado do figado dos animais submetidos ao modelo do RH também revelou a existência de lesōes hepáticas do tipo colangiofibrose, peliose e espongiose, que ocorreram com maior ou menor incidência nos tês grupos experimentais (Quadro 1), e as quais se questiona, todavia, se seriam ou não pré-neoplásicas (BANNASCH e ZERBAN, 1990).

Além disso, este evidenciou a presença do colangioma cístico, alteração agora considerada neoplásica e frequentemente observável no figado de ratos tratados com doses elevadas de hepatocarcinogênicos, mas para a qual não existem evidências de que possa eventualmente vir a progredir para o carcinoma colangiocelular (BANNASCH e ZERBAN, 1990). De qualquer forma, observou-se nesse caso em comparaçāo ao grupo controle (grupo OM), a mesma incidência deste tjpo de neoplasia hepática benigna no grupo de animais tratados com 
$\beta$-caroteno (grupo $\beta C$ ) durante a fase de progressão do modelo do $R H$, enquanto esta foi entetanto menor no grupo de ratos aos quais se administrou a vitamina A (Quadro 1).

Em se tratando do adenoma hepatocelular (nódulo persistente de hepatócito), também considerado uma neoplasia benigna mas para a qual a maioria dos estudos aponta para a existência de uma relação direta do tipo precursor-prodưto entre a mesma e o surgimento da neoplasia maligna hepática (FARBER, 1984a; BANNASCH e ZERBAN, 1990), a análise histopatológica demonstrou, por sua vez, ainda em comparação ao grupo controle (grupo OM), uma incidência pouco menor no figado do grupo de animais submetidos ao modelo do RH e nos quais se aplicou o carotenóide (grupo $\beta C$ ), enquanto se constatou pronunciada reduçāo da mesma no grupo de ratos tratados com o refinóide (grupo VA) (Quadro 1).

Esta análise também revelou menores incidências de carcinomas hepatocelulares quando em comparaçào ao grupo controle (grupo OM), tanto no grupo de animais tratados com o $\beta$-caroteno (grupo BC) como com a vitamina A (grupo VA), e que apresentavam, basicamente, padrões bem diferenciados que foram considerados, no caso, como sendo dos tipos trabecular e glandular (Quadro 1)

Nesse sentido, descreve-se que em nivel histológico podem ser distinguidas tês variedades básicas de hepatocarcinomas, quais sejarn, a do padrão trabecular, glandular (adenóide) e do sólido. Enquanto aś duas primeiras cursam usualmente com um elevado grau de diferenciação e com um melhor prognóstico tanto em animais quanto no ser humano, relatase que as lesões sólidas são predominantemente pouco diferenciadas e evoluem menos favoravelmente (BANNASCH e ZERBAN, 1990; ZERBAN et al., 1994).

De uma forma geral, pode-se, portanto constatar que a análise histopatológica confirmou os resultados já anteriormente observados no presente esłudo por ocasião da realização do exame macroscópico do figado dos animais (Tabela 2), indicando também a ocorência de efeitos inibitórios tanto por parte do $\beta$-caroteno como da vitamina $A$ no desenvolvimento de lesōes pré-neoplásicas e neoplásicas malignas, quando administrados por oito semanas consecutivas especificamente durante a fase de progressāo da hepatocarcinogênese.

\subsection{Sobre as concentrações hepáticas de $\beta$-caroteno e retinol de ratos Wistar submetidos ao modelo do "hepatócito resistente" e tratados com óleo de milho, $\beta$-caroteno ou vitamina A durante a fase de progressāo da hepatocarcinogênese.}

Foram constatadas no presente estudo, concentrações mensuráveis de $\beta$-caroteno no figado dos animais submetidos ao modelo do "hepatócito resistente" $(\mathrm{RH})$ e tratados com o carotenóide por oito semanas consecutivas durante a fase de progressão (grupo $\beta C$ ), ao contrário do que ocorreu nos grupos de ratos também submetidos a esse protocolo de hepatocarcinogênese e aos quais se administrou óleo de milho (grupo OM - controles) ou vitamina A (grupo VA), em que estas não foram detectáveis (Tabela 4). Isto era de certo modo esperável pois durante esse mesmo periodo, estes dois úlfimos grupos experimentais puderam apenas contar com suas raçōes como única fonte de $\beta$-caroteno.

Estes dados estão de acordo, portanto, com resultados de investigações anteriores que demonstraram a ocorrência de um acúmulo quantificável de $\beta$-caroteno intacto no figado e outos órgãos de diversas espécies, incluindo o ser humano, ratos, galináceos, "ferrets", camundongos e cobaias (BONDI e SKLAN, 1984; SHAPIRO et al., 1984; MAYNE e PARKER, 
1986; KRINSKY ef al., 1990; MORENO et al., 1991; OKOH et al., 1993; SARKAR ef al., 1994; MORENO et al, 1995; TEE ef al., 1996; RIZZI et al., 1997; OLIVEIRA, 1998).

Por ocasião do sacrificio na $48^{\mathrm{a}}$ semana os ratos do grupo $\beta C$ tenderam ainda a apresentar concentrações hepáticas de retinol mais elevadas vio que os animais do grupo contole (grupo OM), embora no caso as diferenças nảo tenham alcançado signíficância do ponto de vista estatistico (Tabela 4).

Resultados semelhantes foram também constatados em camundongos submetidos a modelo de carcinogênese de pele induzida pelo DMBA e tratados durante catorze dias consecutivos com $\beta$-caroteno (200 mg/kg de peso corpóreo/dia) durante a fase de progressão (KATSUMURA ef al, 1996), e sugerem que a quantidade do carotenóide que foi convertida em retinoides não foi suficiente para aumentar os niveis teciduais dos mesmos.

Em contrapartida, animais submetidos ao modelo do RH e tatados por oito semanas consecutivas com vitamina A (grupo VA) durante a fase de progressão da hepatocarcinogênese, apresentaram concentraçōes hepáticas de retinol significantemente maiores $(p<0,05)$ do que os ratos dos grupos controle (grupo OM) e $\beta C$ (Tabela 4).

Assim, aumentos nas concentrações hepáticas de $\beta$-caroteno, e não de retinol, podem ser associados, no presente estudo, aos efeitos inibitónios no desenvolvimento de neoplasias constatados nos figados de ratos submetidos ao modelo do $\mathrm{RH}$ e tratados por oito semanas consecutivas com o carotenóide na etapa de progressão da hepatocarcinogênese (grupo $\beta C$ ).

Por outro lado, no grupo de animais tratados com vitamina A durante essa mesma fase da carcinogênese hepática (grupo VA), alterações nas concentrações hepaticas de retinol, e não de $\beta$-caroteno, podem ser tambèm associadas a atividades inibitórias no desenvolvimento de lesões hepáticas pré-neoplásicas e neoplásicas malignas.

Portanto, estes resultados se constituem, conjuntamente, em fortes indicios da existência in vivo de uma atividade intrinseca do $\beta$-caroteno agora durante a etapa de progressão da hepatocarcinogênese, e confirmam evidências anteriores nesse sentido descritas na literatura $e$ constatadas não só em camundongos tratados com o carotenóide durante a fase de progressão da carcinogènese de pele induzida pelo DMBA (KATSUMURA et al., 1996), como também em ratos Wistar submetidos ao modelo do RH, embora nesse caso os animais tenham sido tratados com $\beta$-caroteno em etapas mais iniciais da hepatocarcinogênese (MORENO et al., 1995a; RIZZ) et al., 1997).

Baseado nas concentrações de retinol (vitamina A) constatadas no figado dos animais dos grupos $\beta C$ e VA, bem como nas respectivas doses de $\beta$-caroteno $(7 \mathrm{mg} / 100 \mathrm{~g}$ de peso corpóreo) ou de vitamina $A(1 \mathrm{mg} / 100 \mathrm{~g}$ de peso corpóreo) que estes receberam em dias alternados e por intubação gástrica, calculou-se que a razão de conversão do carotenóide em vitamina A correspondeu, no presente estudo, a um valor aproximado de 34:1.

Isto está de acordo com observações descritas anteriormente na literatura e que demonstraram em diversas espécies de animais, incluindo ratos e galináceos, que a conversão do $\beta$-caroteno em vitamina $A$ diminui inversamente com a ingestão do carotenóide, à medida que suas dosagens forem se tornando cada vez maiores em relação aos requerimentos diários (BEESON, 1965; BAUERNFEIND, 1972; BRUBACHER e WEISER, 1985).

Está ainda de acordo com os resultados de uma investigação anterior também conduzida em ratos Wistar submetidos ao modelo do $\mathrm{RH}$ e tratados por oito semanas consecutivas com $\beta$-caroteno e vitamina $A$ nas mesmas dosagens que as utilizadas no presente estudo, embora esses tratamentos tenham sido realizados, no caso, em ratos mais jovens e durante as fases iniciais da hepatocarcinogênese, tendo-se constatado uma razão de conversāo bem menor e correpondendo a 14:1 (MORENO et al., 1995a). 
Não se tem até o momento uma explicação convincente que pudesse esclarecer essas diferenças observadas em relação às razões de conversão constatadas nesses dois estudos.

Descreve-se, entretanto, que o grau de conversão do $\beta$-caroteno em vitamina A não é constante, sendo regulado por mecanismos homeostáticos envolvidos, por exemplo, com 0 controle da saturação dos depósitos de retinol do organismo bem como com a taxa de absorção do carotenóide em nivel intestinal e sua posterior clivagem em vitamina $A$, um processo que ocorre não só na mucosa intestinal da maioria dos mamíferos como também no figado e em diversos outros órgãos (BEESON, 1965; GERSTER, 1991; SILVEIRA e MORENO, 1998).

Assim, talvez esses mecanismos homeostáticos apesar de se manterem vigentes e provavelmente atuantes no sentido de proteger o organismo contra a ocorrencia de uma eventual hipervitaminose A (GERSTER, 1991), venham ainda soffer alteraçoes com o decorrer do tempo, o que poderia explicar não só o aumento não significante das concentrações hepáticas de refinol observado após a administração de $\beta$-caroteno (grupo $\beta C$ ) como também sua maior razão de conversão constatada na presente investigação, desde que nesta se deu início às aplicações do carotenóide quando os ratos já eram bem mais idosos que na investigação anterior.

Além disso, ainda nesse sentido, não se pode também excluir um papel da própria carcinogènese hepática que se encontrava no atual estudo em uma etapa já bem mais avançada, como eventual processo que pudesse ter interferido por tempo mais prolongado, e agora de forma mais intensa, com os mecanismos responsáveis pelo controle do grau de conversão do $\beta$-caroteno em vitamina $A$.

\subsection{Sobre a proliferação celular no figado e lesões neoplásicas hepáticas de ratos Wistar submetidos ao modelo do "hepatócito resistente" e tratados com óleo de milho, $\beta$ - caroteno ou vitamina $A$ durante a fase de progressão da hepatocarcinogênese.}

Estima-se que no figado do rato adutto o período de vida das celulas parenquimatosas compreenda cerca de $200-400$ dias (ROTSTEIN et al., 1986). Assim, este consiste, nomalmente, em um órgão quiescente que exibe atividade replicativa minima.

De fato, mitoses sāo constatadas, nesse caso, em aproximadamente 1 em cada 20.000 hepatócitos, embora taxas mais elevadas de proliferação celular sejam observadas durante 0 crescimento e desenvolvimento do figado (STEER, 1995).

Dois tjpos de estimulo proliferativo foram identificados nesse órgão: a hiperplasia celular compensatoria (regenerativa) e a direta, ou mitogeno-induzida. Na primeira, a sintese de DNA é precedida por uma perda de células como a que ocorre, por exemplo, após ressecção cirúrgica parcial, injüria química, vascular, nutricional ou por hepatite viral, enquanto na hiperplasia direta a sintese de DNA é estimulada sem perda celular, por substâncias mitogênicas tais como o nitrato de chumbo, proliferadores de peroxissomos, fenobarbital e acetato de ciproterona (COLUMBANO e SHINOZUKA, 1996). Neste último caso, assim que o estímulo mitogênico é suspenso, a massa e o conteúdo de DNA hepáticos regridem caracteristicamente, graças à apoptose (COLUMBANO, 1995).

A proliferação de hepatócitos induzida por alguns mitógenos primários é mediada por padröes de modulaçăo de fatores de crescimento e transduçăo do sinal, diferentes daqueles observados na regeneração compensatória. Assim, enquanto a ativação de fatores de transcrição como o NF-kB e a expressão aumentada de genes precoces imediatos tais como c-fos, c-jun, egr-1 e c-myc são induzidas durante a regeneração compensatória, tais ałterações não são 
observadas durante a hiperplasia induzida por certos mitógenos primários (STEER, 1995; COLUMBANO e SHINOZUKA, 1996). Além disso, descreveu-se que os niveis das quinases depedentes de ciclina CDK4 e COK5, bem como da proteina ciclina D3, importantes para 0 controle do ciclo celular normal, aumentam após hepatectomia parcial mas não após administraçăo de WY14.643, um proliferador de peroxissomos com potente atividade mitogênica hepática (RININGER et al, 1997).

Ainda nesse sentido, apesar de evidências experimentais sugerirem um papel crítico para fatores de crescimento do tpo do fator de crescimento do hepatocito (HGF) e do transformante $\alpha$ (TGF- $\alpha$ ) para a progressão no ciclo celular de hepatócitos competentes na regeneração compensatória, estes não parecem desempenhar um importante papel na hiperplasia míógenoinduzida (COLUMBANO e SHINOZUKA, 1996).

Portanto, essas diferenças em eventos moleculares observados entre as hiperplasias compensatória e direta podem afetar de forma diversa, as diferentes etapas da hepatocarcinogènese química.

Assim, apesar de não ser conhecido o mecanismo exato através do qual esta atua na iniciação, foi ressaltado o envolvimento da proliferação celular na fixação de uma eventual lesão no DNA recém sintefizado (COLUMBANO et al.; 1981). Na maioria dos estudos designados nesse sentido, o estimulo proliferativo foi realizado através de regeneração compensatória. Nessas circunstâncias, a regeneraçāo hepática é de fato necessária à iniciação por agentes químicos. Entretanto, demonstrou-se também, que doses de carcinogênicos que induzem o evento de iniciação quando acopladas à regeneraçāo hepática, foram incapazes de iniciar as células hepáticas quando associadas à proliferação celular induzida por mitógenos diretos (COLUMBANO et al, 1987; COLUMBANO e SHINOZUKA, 1996). Além disso, foi observada incapacidade da hiperplasia direta em dar suporte à iniciação por carcinogênicos quimicos, apesar da presença de lesão do DNA.

Não está ainda claro, portanto, se esła incapacidade se deve à deficiência de algum evento molecular necessário à iniciaçăo, ou se as células iniciadas são formadas e preferencialmente eliminadas por apoptose durante o processo subsequente de regressāo da hiperplasia inicial. Nesse sentido, sugeriu-se, ainda, que a eliminação de numerosas células alteradas por carcinogênicos ocorre "espontaneamente" logo após a iniciação (DRAGAN et al, 1994a).

Uma outra etapa em que a proliferaçăo celular exerce um efeito crítico na hepatocarcinogènese, é a da promoçăo de células íniciadas por carcinogênicos (DRAGAN et al, 1994b). Assim, descreve-se um aumento na incidéncia de lesões pré-neoplásicas e neoplasias após regeneração compensatória induzida por hepatectomias parciais repetidas ou múltiplos tratamentos com agentes necrogênicos (POUND e McGUIRE, 1978; DRAGANI ef al., 1986; COLUMBANO et al., 1990). Por outro lado, nesse sentido o efeito da hiperplasia mitógenoinduzida é ainda controverso, devido em parte ao fato de alguns mitógenos diretos, como por exemplo os proliferadores de peroxissomos, também apresentarem, concomitantemente, atividade como carcinogênicos completos (RAO e REDDY, 1987).

Entretanto, têm se acumulado evidências de que alguns mitógenos primánios, apesar de suas capacidades de estimularem a proliferação de hepatócitos normais, exercem, na verdade, um efeito inibitório in vivo sobre a proliferação celular de lesões pré-neoplásicas hepáticas (CHEN et al., 1994; COLUMBANO e SHINOZUKA, 1996).

A persistência de uma taxa aumentada de proliferação celular pode também influenciar a etapa de progressão da hepatocarcinogênese. Assim, demonstrou-se que apesar das células alteradas presentes na etapa de progressảo da hepatocarcinogênese já apresentarem um crescimento autônomo, este processo foi influenciado pela presença ou nāo de um agente 
promotor, o que se evidenciou pela redução no período de latência do surgimento da neoplasia na presença continua desse agente, quando comparado à ausência do mesmo (DRAGAN ef al., 1993). Além disso, ao contrário da esperada redução na proliferação celular após suspensão da administração do agente promotor, ratos submefidos a um protocolo de hepatocarcinogênese no qual se utilizou o agente progressor etilnitrosouréia, apresentaram manutenção na proliferação celular de focos de hepatócitos marcados pela enzima GST-P, por ocasião da suspensão da administração de fenobarbital (DRAGAN et al., 1994b).

Deste modo, considera-se que a proliferação celular desempenhe um importante papel nas várias fases da hepatocarcinogênese, ou seja, na iniciação, promoção e progressão, tendose ainda constatado que esta aumenta gradualmente dos tecidos nomais ao carcinoma, incluindo nessa sequência os tecidos pré-neoplásicos e, a seguir, o adenoma (FARBER e SARMA, 1987; FARBER, 1991b; DRAGAN ef al., 1994b; ZERBAN et al, 1994).

Assim, um dos possiveis mecanismos eventualmente responsável pelas atividades antineoplásicas do $\beta$-caroteno ou da vitamina A poderia envolver uma inibição da proliferação celular.

Portanto, foram realizadas no presente estudo avaliaçōes em que se utilizou inicialmente um método bioquímico simples capaz de determinar quant́tativamente as concentrações hepáticas de DNA e, deste modo, de indicar rapidamente a ocorrência ou não de variações na proliferação celular e, a seguir, determinaçōes do indice de marcação da BrDU atsavés de técnica imunohistoquímica já bem mais sensivel e especifica que a anterior, também amplamente empregada com essa finalidade em estudos de carcinogênese (MELNICK, 1992; DOLBEARE, 1995; FOSTER, 1997).

Observou-se, logo de inicio, em comparação ao grupo contole (grupo OM) que a administração por oito semanas consecutivas de $\beta$-caroteno ou vitamina $A$ após 40 semanas da realização do processo de iniciação com o carcinogênico DEN, reduziu significantemente $(p<0,05)$ as concentraçōes de DNA nos figados de animais submefidos ao modelo do RH (Tabela 5).

Da mesma forma, constatou-se posteriormente que tanto o tratamento com o carotenóide (grupo $\beta C$ ) como com o retinóide (grupo VA) foram capazes de reduzir o índice de marcação para a BrDU dos hepatócitos em áreas consideradas "normais" ao redor de lesōes hepaticas (nódulos/cânceres), bem como nas próprias lesōes, embora essa diferença não tenha atingido significância estatjstica em relação ao respectivo grupo controle, especificamente apenas no caso das lesões constatadas nos figados de animais aos quais se administou a vitamina $A$ (Tabela 6).

Portanto, conjuntamente tais resultados se constituem em fortes indicios de que 0 Bcaroteno e a vitamina $A$ apresentam um efeito inibitório na proliferação celular quando administrados durante a etapa de progressão da hepatocarcinogênese e confirmam dados de um trabalho recente em que tal atividade foi também detectada em ratos Wistar submetidos ao modelo do $\mathrm{RH}$, apos tratamento com o retinóide também por oito semanas consecurivas e durante a mesma fase da carcinogênese hepática (SILVEIRA, 1998).

Constatou-se ainda no presente estudo através da determinação do índice de marcaçāo para a BrDU que áreas hepáticas consideradas "normais" ao redor das lesões de animais submetidos ao modelo do RHe tratados com óleo de milho durante a fase de progressáo (grupo OM - controles), apresentavam uma maior proliferaçāo de hepatócitos $(0<0,05)$ que amostras de figado obtidas de ratos que não foram submetidos a esse protocolo de hepatocarcinogênese (Tabela 6).

Além disso, observou-se que lesões hepáticas (nódulos persistentesicânceres) de animais submetidos ao modelo do RH e tratados com bleo de milho (grupo OM --controles), $\beta$-caroteno 
(grupo BC) ou vitamina A (grupo VA) demonstravam uma maior proliferação celular do que em suas respectivas áreas de figado consideradas "normais" aos seus redores, embora estas diferenças tenham alcançado significância estatistica $(p<0,05)$ somente nos dois primeiros grupos experimentais (Tabela 6).

Tais resultados estão, portanto, também de acordo com as evidências da literatura já citadas anteriormente (FARBER e SARMA, 1987; FARBER, 1991b; DRAGAN et al., 1994b; ZERBAN et al, 1994) e que demonstram que a proliferaçazo celular aumenta à medida que a hepatocarcinogênese evolui.

Observações semelhantes às do presente estudo foram também constatadas em investigações realizadas in vitro em que se observou que o carotenóide foi capaz de inibir a proliferação de fibroblastos C3H 10T1/2 de embriōes de camundongo (PUNG et al., 1988), de células B-16 de melanoma de camundongo (HAZUKA et al, 1990), bem como de células SK-MES de carcinoma pulmonar e SCC-25 de carcinoma oral de ser humano (SCHWARTZ et al., 1990; 1992).

Além disso, estas estão ainda de acordo com as evidências de tees estudos já publicados mais recentemente em que se demonstrou, em um deles, realizado com culturas de células da linhagem osteogênica clonal MC3T3-E1, que tanto o $\beta$-caroteno como o retinol foram capazes de inibir a proliferação celular e a capacidade de sintese de DNA (PARK et al., 1997), e nos dois outros, realizados com culturas de células HL-60 originärias de paciente portador de leucemia promielocítica, em que a incubação com o carotenóide por periodos e em concentrações variáveis resultou em uma inibição significante de seus números (GROSS ef al., 1997; BIESALSKI e SCHÄFFER, 1997).

Nessas duas últimas investigaçōes, como também no presente estudo, os resultados sugeriram que o $\beta$-caroteno poderia estar eventualmente atuando de forma intrinseca diretamente relacionada com sua molécula intacta, e não como pró-vitamina A. No primeiro caso tal conclusão se baseou na constatação de que tanto o $\beta$-caroteno como a luteína, um carotenbide sem atividade pró-vitamínica $A$, foram capazes de inibir significantemente a proliferação de células HL-60 (GROSS ef al., 1997) e, no segundo, no fato de não se ter constatado nas culturas a presença concomitante de ácido retinöico que pudesse ter sido produzido a partir do carotenbide presente no meio de incubação (BIESALSKI e SCHÄFFER, 1997).

Pelo número exíguo de publicaçōes encontrado na literatura especializada, pode-se constatar que em apenas algumas outras poucas oportunidades que não no atual estudo, procurou-se também avaliar in vivo os efeitos do $\beta$-caroteno na proliferação celular.

Assim, descreveu-se em um modelo de carcinogênese de lingua induzida em ratos Machos F-344 pelo 1-óxido de 4-nitroquinolina (4-NQO) que o $\beta$-caroteno administado nas rações dos animais (500 p.p.m.) durante as fases de iniciação e pós-iniciação reduziu significantemente as incidências de lesōes pré-neoplásicas e de carcinomas de lingua por ocasiāo do sacrificio na 32a semana, as concentraçōes teciduais das poliaminas diamina, espermidina e espermina, bem como a proliferação celular estimada pelo indice de marcação para a BrDU e por analises morfométricas de regiöes organizadoras nucleolares coradas pela prata (AgNORs) (TANAKA et al, 1994).

Aumentos das concentraçóes de poliaminas elou da abvidade da enzima ornifina descarboxilase (ODC), considerada a etapa crítica na biossintese das poliaminas, correlacionaram-se em diversos tecidos com a taxa de sintese de DNA e a proliferação celular, tendo-se ainda atribuido um importante papel para a enzima na promoçāo de neoplasias em vários modelos de carcinogènese (PEGG, 1988). 
Por outro lado, relatou-se também já mais recentemente que a administração de $\beta$-caroteno nas rações durante as etapas de iniciaçāo/promoçāo inicial ou durante a promoção tardia resultou em efeitos quimiopreventivos em modelo de carcinogênese pancreática induzida em ratos pela aplicação de azasserina, embora tenha aumentado paradoxalmente nessas ocasiōes a proliferação celular em focos acinares atípicos, determinada pelo indice de marcação para a BrDU (APPEL e WOUTERSEN, 1996).

Já em seres humanos, para os quais vem sendo inclusive considerada como promissora e recomendada para ensajos de quimioprevenção em pequena escala a utilização de biomarcadores de prolíferação celular no colon do tipo da determinação do indice de marcação para a BrDU ou da atividade da enzima ODC (BOWEN e MOBARHAN, 1995; GERSTER, 1996), observou-se em um estudo conduzido em grupos constituldos de 10 pacientes que receberam ou não suplementos de $\beta$-caroteno $(9 \mathrm{mg})$, vitamina $E(160 \mathrm{mg})$ ou vitamina $C(750 \mathrm{mg})$ diariamente por quatro semanas consecutivas, respectivamente, que tanto o carotenóide como a vitamina C foram capazes de inibir significantemente o indice de marcação para a BrDU enquanto isto não ocorreu no grupo não-suplementado ou suplementado com vitamina E (CAHIL ef al, 1993).

Além disso, descreveu-se que em um grupo de vinte pacientes que haviam sofrido resseçãa prévia de um adenocarcinoma de colon, a suplementação diánia com $\beta$-caroteno (30 mg) por 6 meses, reduziu significantemente em $44 \%(p<0,05)$ após duas semanas a atividade da enzima ODC em amostras de biópsia retal em comparação à atividade constatada quando do início do estudo, e em $57 \%(p<0,01)$ após 9 semanas. Após 16 e 24 semanas constatou-se ainda nesse caso, reduções na atividade dessa enzima correspondentes a $30 \%$ e $35 \%$, respectivamente (PHILLIPS ef al, 1993).

Da mesma forma, observou-se ainda em um ensaio conduzido em pacientes portadores de gastrite atrófica e cujas atividades da enzima ODC na mucosa gástrica já se encontravam previamente elevadas, que o tratamento diário com $20 \mathrm{mg}$ de $\beta$-caroteno por três semanas consecutivas resultou em uma redução significante na atividade da enzima, em comparação a controles não-tratados (BUKIN et al., 1993).

É também pequeno o número de estudos relatados na literatura em que se avaliou os eventuais efeitos da vitamina A na proliferação celular, ao contrário do que se observa em relação ao ácido retinóico e a diversos retinóides sintéticos.

Assim, constatou-se in vitro através de técnicas de autorradiografia com timidina tritjada, que a vitamina A foi capaz de inibir significantemente a sintese de DNA e a proliferaçāo celular quando adicionada ao meio de cultura de células de carcinomas escamosos ou basais de pele, induzidos em camundongos pela aplicação de 3-metilcolantreno (LUPULESCU, 1986; 1993).

Observou-se também um efeito inibitório por parte do acetato de retinila na estimulação da sintese de DNA induzida pelo soro em fibroblastos C3H 10T1/2 tratados com carcinogênico, provavelmente decorrente de um bloqueio na transição da etapa G0 para G1 da resposta mitótica das células iniciadas a fatores de crescimento plaquetários (MORDAN, 1989).

Jà em experimentos in vivo, teve-se também a oportunidade de demonstrar em ratos submetidos a modelo de carcinogênese mamária induzida pela administração de DMBA ou MNU e alimentados com raçōes suplementadas com acetato de retinila, a ocorrência de uma inibição da sintese de DNA quando esta foi determinada através da incorporação de timidina triciada (MOON E MEHTA, 1986).

Demonstrou-se ainda que em ratos uma única injeção intraperitoneal do agente promotor acetato de tefradecanoilforbol (TPA) resultou em um aumento transitório da atividade da enzima ODC no figado, o qual foi inibido quando se administrou o acetato de retinila nos animais uma hora antes da aplicação do TPA (BISSCHOP et al., 1981). 
Portanto, os efeitos anti-neoplásicos do $\beta$-caroteno e da vitamina A observados no presente estudo durante a etapa de progressão da hepatocarcinogênese podem ter sido também eventualmente mediados por uma inibição da proliferação celular. Além disso, no caso especifico do carotenóide talvez este efeito inibitório possa ser ainda relacionado a áigum mecanismo intrinseco dependente diretamente da estrutura de sua molécula e não à sua açāo como pró-vitamina A.

Dos muitos eventos que acontecem no interior de uma célula durante toda sua existência, a divisão em duas consiste em um dos mais complexos, sendo assim fundamental para a vida que ocorra com sucesso.

É o estado de diferenciação da célula que vai ditar quando e sob quais circunstâncias esta proliferará. Em geral células diferenciadas proliferam em resposta a sinais extracelulares especificos e que incluem hormônios e citocinas estimulatórias ou inibitórias da proliferação, a matriz extracelular ou substrato das células com que estas estabelecem contato, e o tpo e grau de proximidade com as células vizinhas. Os mesmos fatores são também frequentemente importantes reguladores da diferenciação (OSHIMA e CAMPISI, 1991).

Entende-se por ciclo celułar o processo no qual uma única célula eucariótica dá origem a duas células filhas, através de quatro etapas em sèrie biologicamente definidas e designadas por: G1 ("gap" 1); S (ou de sintese do DNA); G2 ("gap" 2) e M (de mitose) (REDDY, 1994). A conclusão da sequência de eventos metabólicos especificos de cada uma delas prepara a célula para a etapa seguinte.

Na maioria dos tecidos as células se encontram em um estado quiescente, nãoproliferante, denominado de "GO". Ao contrário de células termínalmente diferenciadas, as em GO retêm a capacidade de entrar no ciclo celular proliferativo, respondendo a fatores extracelulares (REDDY, 1994).

O controle do ciclo celular constitui o principal mecanismo regulatório da proliferaçāo, sendo em geral exercido nas etapas $\mathrm{GO}$ para $\mathrm{G} 1$ e em $\mathrm{G} 2$. Os mecanismos que operam nesta última parecem ser comuns a todas as células, enquanto diversos eventos especíicos a cada tipo de célula tendem a operar na etapa G1 (OSHIMA e CAMPISI, 1991).

Assim, dependendo das condiçőes extracelulares, a "decisão" para uma celula em GO entrar no ciclo celular ou para as células que nele se encontram ciclando sairem novamente para essa etapa é adotada, em última instância, pouco antes da fase $\mathrm{S}$ e em um periodo tardio da etapa G1 (REDDY, 1994).

Descreve-se, ainda, que a divisão celular poderia também ser separada em quatro outras fases distintas que incluiriam: a geração do sinal, reconhecimento do mesmo, sua transduçāo e, finalmente, a resposta, ou seja, a replicaçăo do DNA e a divisão celular (BOS e van KRElJL, 1992; FOSTER, 1997).

$O$ inicio do processo está sob controle de um sinal externo, que pode ser tanto um fator humoral como local. Exemplos seriam hormônios tais como insulina e estrógenos, citocinas como o fator $\alpha$ de necrose tumoral (TNF- $\alpha$ ) e fatores de crescimento incluindo o do hepatócito (HGF) e o epidermal (EGF), que estimulam a proliferação de uma ampla variedade de células epiteliais no figado, pele e estômago (LINDROOS et al., 1990; DIEHL e RAl, 1996).

Já o reconhecimento do sinal para proliferação requer a presença de receptores seja na membrana plasmática das células, no citoplasma ou no núcleo (CARPENTER, 1987).

A interação dos hormônios ou fatores de crescimento com os receptores apropriados resulta em uma sequência de eventos conhecida coletivamente como transdução do sinal, que pode terminar, por sua vez, em uma série de diferentes processos tais como a replicação celular, sintese de proteinas ou até mesmo na apoptose (FOSTER, 1997). 
Eventos comuns que ocorrem após a ligação aos receptores, como por exemplo ao receptor EGF, incluem a dimerização ou oligomerização do receptor, ativação da via do fosfatidilinositol, estimulação de proteina quinase $C$ serinaltreonina específica e mobilização dos depósitos intracelulares de cálcio. A fosforilação concomitante de proteinas ricas em tirosina e serina torna possivel a liberação de fatores de transcrição de seus locais citoplasmáticos de ancoragem, possibilitando que estes sejam translocados para o núcleo e ativem a expressão gênica (ULRICH e SCHLESSINGER, 1990).

Já a produção das assim chamadas trifosfatases de guanosina (GTPases), incluindo p21ras, e a ativação de quinases transdutoras como a quinase peptídeo mitógeno ativado resultam em uma série de alteraçōes para o preparo da síntese do DNA e da replicaçāo celular (BOS e van KREIJL, 1992).

Os proto-oncogenes c-fos, c-jun e c-myc que atuam como fatores de transcrição são comumente ativados em consequência da ligação com o receptor e da transdução do sinal, podendo ocorrer a ativação e fosforilação após estimulação das células com uma diversidade de agentes tais como ésteres de forbol, ionóforos de $\mathrm{Ca}^{2 *}$, neurotransmissores, citocinas e fatores de crescimento (BISHOP, 1991; EDWARDS, 1994).

Já os produtos dos anti-oncogenes $p 53$ e it são capazes de exercerem uma influência controladora sobre os eventos moleculares que induzem a célula a proliferar, bloqueando a progressão no ciclo celular da etapa G1 para S (BISHOP, 1991; REDDY, 1994; BURDON, 1995).

Além disso, para que a célula responda adequadamente à interação do fator de crescimento com seu respectivo receptor e entre na etapa G1 do cicto celular, são necessárias ainda ciclinas, proteínas que são sintetizadas e degradadas em diferentes etapas do cicło de divisão celular, bem como uma proteina quinase especifica codificada pelo gene para o fator promotor da maturaçäo/mitose (MPF; colc2/CDC28 em leveduras) (BISHOP; 1991; ROBERTS, 1993).

A ligação dessa proteína quinase a uma ciclina forma um complexo que determina a passagem das células por G1e para a etapa $S$ (de sintese do DNA), e que foi denominado de "ponto de restrição". Este corresponde ao momento decisivo na etapa G1 tardia em que ocorre a definição se a célula irá se dividir ou diferenciar entrando novamente em GO (FOSTER, 1997).

A transiçáo subsequente de uma etapa para outra do ciclo celular é regulada por uma combinação de mecanismos transcricionais, pós-traduçāo e de associaçōes quaternárias de proteinas, em que ciclinas e proteina quinases ciclina-dependentes (CDKs) desempenham importantes papéis, bem como a fosforilação de várias subunidades protéicas (JACOBS, 1992; FOSTER, 1997).

Assim, as CDKs 2, 4 e 5 em conjunto com as ciclinas C, D e E foram implicadas com a passagem pela etapa G1 do ciclo celular, enquanto CDK1 e CDK2 e as ciclinas A e B parecem ser criticas durante as etapas S e M NAN DEN HEUVEL e HARLOW, 1993; HUNTER e PINES, 1994; NURSE, 1994).

Proteínas inibitórias (CDIs) incluindo p21 (WAF1/CIP1), p27 (Kip1) e p16 (Ink4), também contribuem para a regulação da progressão no ciclo celular, controlando a atividade de CDKs; p16 é especifica para complexos ciclina-CDK4 enquanto p21 e p27 inibem in vitro uma ampla variedade de complexos ciclina-CDKs, incluindo complexos CDK2 e CDK4. A hiperexpressão dessas proteinas bloqueia a progressäo das células pela etapa G1 (HUNTER e PINES, 1994).

A transformação de uma célula normal em uma que prolifera de modo descontrolado consiste em um processo altamente complexo em múltiplas etapas e que não é ainda completamente compreendido. Teoricamente espécies reativas de oxigênio podem desempenhar um papel em todas as fases da carcinogênese, mas de que forma isto ocorre também nåo está ainda claro (FRENKEL, 1992; SLAGA, 1995). 
Evidências demonstram que uma ampla variedade de células normais e malignas produz e libera in vitro superóxido ou peróxido de hidrogênio em resposta a estímulos por citocinas e fatores de crescimento específicos ou constitutivamente no caso das células neoplásicas, tendo-se sugerido que intermediários reativos de oxigênio poderiam desempenhar um importante papel como mensageiros secundários inta e intercelulares (BURDON, 1995; SCHULZE-OSTHOFF et al., 1997). Estes poderiam contribuir para com a transdução do sinal mediada por alteraçōes na fosforilação de proteinas ricas em tirosina através de açōes nas atividades de quinases e fosfatases, bem como para com a regulaçāo de fatores de transcriçāo tais como NF- $k B, A P-1, c-m y c, c$-fos e p53, e desta forma atuar no controle da proliferação celular (BURDON, 1995; SEN e PARKER, 1996; POWIS et al., 1997; PRIMIANO et al, 1997; SCHULZE-OSTHOFF et al., 1997; WASSERMAN e FAHL, 1997).

De fato, observou-se que tanto o superóxido como o peróxido de hidrogênio quando adicionados exogenamente podem estimular a proliferação celular de uma variedade considerável de células de mamiferos em cultura (BURDON, 1995).

Por outro lado, experimentos nos quais se adicionou as enzimas antioxidantes superóxido dismutase ou catalase exogenamente ao meio de cultura de fibroblastos de hamster ou rato (BURDON, 1992), bem como de células promielociticas HeLa (BURDON e GILL, 1993), resultaram em diminuição da proliferaçăo celular.

Da mesma forma, descreve-se que o tratamento com superóxido dismutase miméticos (EGNER e KENSLER, 1985) ou a transferência do gene da enzima superóxido dismutase (CHURCH et al., 1993), inibiu a progressão da carcinogênese de pele em camundongos e reverteu o fenótjpo neoplásico de células de melanoma humano, respectivamente.

Portanto, talvez antioxidantes como o $\beta$-caroteno poderiam inibir a proliferação celular através de suas capacidades de neutralizar espécies reativas de oxigênio que atuam como uma espécie de mensageiros secundários, com consequente inibição da ativação de vias da transdução do sinal e de fatores de transcriçāo como o NF-kB, c-myc (que desempenha um papel essencial na proliferação celular), c-fos e AP-1 (BURDON, 1995; SCHULZEOSTHOFF et al., 1997; NAVES e MORENO, 1998).

Vale entretanto também lembrar que os efeitos quimiopreventivos de carotenóides contra o câncer parecem depender não apenas diretamente de suas estrưuras, com duplas ligaçōes capazes de sequestrarem espécies reativas de oxigênio ou radicais livres e assim atuarem como antioxidantes, como também de outros mecanismos que influenciam concomitantemente a expressão de genes importantes para a regulação da proliferação e da diferenciação celulares (NAVES e MORENO, 1998).

Esta sugestāo está de acordo com a descrição de que o $\beta$-caroteno pode induzir a expressão da proteína quinase cdc2 (um dos reguladores do ciclo celular), das ciclinas $A \in D$, de proteínas relacionadas com o estresse e do anti-oncogene $p 53$ selvagem, enquanto inibe a expressão do $p 53$ mutante, do receptor para o fator de crescimento epidermal (EGF), do fator de transcrição c-fos e do proto-oncogene c-raf, que também codifica para proteina quinase envolvida com o controle do ciclo celular (SCHWARTZ et al., 1990; 1993; SCHWARTZ, 1994; BURDON, 1995; MUTO et al., 1995), bem como inibe a hiperfosforilaçăo de proteínas celulares o que talvez tivesse alguma correlação, inclusive, com a observação de que este carotenóide é capaz de bloquear o ciclo celular nas etapas G0/G1 e G2 (SCHWARTZ ef al., 1992; 1993; SCHWARTZ, 1994; MATSUSHIMA-NISHIWAKI of al., 1995).

Esta ainda de certa forma de acordo com a constatação de que a ativação do fator de transcrição NF-kB pode ser prevenida quando as células em cultura sāo pré-tratadas com compostos antioxidantes do tipo da vitamina $E, N$-aceilcisteína, ácido lipóico, torredoxina, ditiocaroamatos e fenólicos como o hidroxianisol butilado (SCHUL ZF-OSTHOFF et al., 1995; 1997). 
Além disso, concorda também com a observação de que o $\beta$-caroteno inibe a expressāo do proto-oncogene c-myc de uma forma intrínseca e independente de sua ação como próvitamina $A$, quando esta foi utilizada como um parâmetro para estimativa da prolíferação celular em papilomas de camundongos tratados com o carotenoide (KATSUMURA et al, 1996), bem como a transdução do sinal dependente da atividade da proteína quinase C em células $S W 480$ de carcinoma de cólon humano (KAHL-RAINER e MARIAN, 1994; GERSTER, 1996).

Todavia, não está de acordo com a constatação de certo modo supreendente, de que o fator AP-1 softe importante ativaçāo após tratamento das células em cultura com ơiversos antioxidantes estruturalmente não-relacionados (SCHULZE-OSTHOFF et al., 1997).

Entretanto, no caso específico desse fator de tanscrição, pode-se aventar que o $\beta$-caroteno poderia também estar atuando através de sua açăo como pró-vitamina A e não como antioxidante, pois se descreve que o fator de transcrição AP-1 também pode ser inativado por retinóides através de sua interação com os receptores RAR e RXR, por um mecanismo denominado de transrepressão (SALBERT et al, 1993; SILVEIRA e MORENO, 1998).

Além disso, o $\beta$-caroteno poderia também inibir a proliferação celular através de sua capacidade de estimular a formação de junções do tpo hiato ("gap junctions") via indução da expressão do gene para a conexina 43 (ZHANG et al., 1992; 1995), ou de inibir a enzima HMGCoA redutase, cuja atividade é considerada crítica para o metabolismo do colesterol e de outros derivados do mevalonato necessários não só à síntese de membranas celulares em animais, como também à própria sintese do DNA (SOMA et al., 1992; MORENO et al., 1995; FUHRMAN et al., 1997).

Finalmente, 0 ß-caroteno poderia estar ainda inibindo a proliferação celular através de uma estimulaçāo da diferenciação, o que altera o fenotjpo da célula e reduz as alterações associadas com a malignidade e a proliferação (CASEY, 1991), como o observado em culturas de células da linhagem osteogênica clonal MC3T3-E1 (PARK et al., 1997), de células HL-60 de leucemia promielocitica aguda (BIESALSKI e SCHÄFFER, 1997; GROSS et al., 1997) e de células F9 de carcinoma embrionário (NIKAWA et al., 1995).

Como já mencionado anteriomente, no caso dos estudos realizados com culkuras de células HL-60, o $\beta$-caroteno pareceu também estar atuando diretamente na diferenciaçāo das células e não na forma de pró-vitamina A (BIESALSKI e SCHÄFFER, 1997; GROSS et al., 1997). Já em culturas de células $F 9$, descreve-se que provavelmente atusou após sua transformação em ácido retinóico (NIKAWA et al., 1995).

Assim, este mecanismo também está classicamente relacionado à atividade antiprolfferativa dos retinóides, constituindo inciusive a base racional da assim denominada terapia de diferenciaçä" da leucemia promielocítica aguda com ácido retinoico todo-trans (HUANG ef al, 1988; BOONE ef al., 1990, 1992; WARRELL ef al., 1993; GUDAS et al., 1994; CHOMIENNE ef al., 1996; SILVEIRA e MORENO, 1998).

Já em relação aos mecanismos através dos quais a vitamina A poderia estar inibindo a proliferação celular, acredita-se que estes estejam relacionados, primariamente, a seu metabolismo em ácido retinóico. Este modularia, por sua vez, de uma forma direta ou indireta as expressões dos inúmeros genes cujos produtos estão envolvidos com o controle das várias etapas da divisão celular, basicamente graças à sua interação inicial com os receptores nucleares RAR e RXR, bem como com as proteinas ligadoras de ácido retinóico (CRABPS) (GUDAS et al., 1994; CHAMBON, 1996; SILVEIRA e MORENO, 1998).

Alguns exemplos desses mecanismos já aventados na líteratura e que se basearam em evidências obtidas a partir de estudos realizados tanto in vitro como in vivo e nos quais se demonstrou uma inibição da proliferação celular após tatamento com o ácido retinóico incluiriam: uma açăo estimulante da afividade do fator inibitório da proliferaçāo celular 
denominado de fator $\beta$ transformante do crescimento (TGF- $\beta$ ), aumentando tanto a expressão do ligante como de seu receptor; uma atividade inibitória da expressão de fatores mitogênicos como o fator $\alpha$ transformante do crescimento (TGF- $\alpha$ ), o fator de crescimento epidermal (EGF) e o fator de crescimento I ínsulina-símile (IGF-I); uma inibição da expressāo do gene para a enzima ODC; uma atividade modulatória sobre as junções do típo hiato e da expressāo do gene para a conexina 43; e um efeito inibitório da expressão de proto-oncogenes tais como c-fos e c-jun, cujas proteinas formam o dímero AP-1, bern como c-myc, c-myt (GUDAS ef al., 1994).

Além disso, descreve-se que retinoides, mais especificamente o retinol, poderiam ser fosforilados e subsequentemente glicosilados com manose dando origem ao fosfato de manosilretinila, que alteria propriedades da membrana plasmática inctuindo a secreçāo, assim modulando a proliferação e a diferenciaçåo celulares (JETTEN, 1984).

Refinóides em concentrações elevadas ao penetrarem nas membranas poderiam ainda causar mudanças em seus domínios e propriedades fisicoquimicas como a microviscosidade, com consequentes alteraçōes na permeabilidade a ions e nas atividades de enzimas ligadas à membrana, o que também explicaria a modulação da proliferação celular exercida por essas substâncias (JETTEN, 1984).

Já bem mais recentemente demonstrou-se ainda que o ácido refinóico pode interferir com a progressāo do ciclo celular e dessa forma reduzir a proliferação de células MCF-7 de carcinoma mamário humano, inibindo inicialmente as expressōes da ciclina D3 e da proteína quinase CDK4 e, a seguir, a expressão e a fosforilacão do produto do gene do retinoblastoma (pRB), uma proteína nuclear que funciona como um antioncogene, bem como a expressào subsequente do fator de transcrição E2F1 que controla a progressão da fase G1 para S (ZHU et al., 1997).

6.6 Sobre o padrão de metilação dos proto-oncogenes c-Ha-ras e c-myc, bem como do gene que codifica para a enzima HMGCoA redutase, do figado e de lesōes hepáticas (nódulos persistentes/cânceres) de ratos Wistar submetidos ao modelo do "hepatócito resistente" e tratados com óleo de milho, $\beta$-caroteno ou vitamina $A$ durante a fase de progressão da hepatocarcinogênese.

Alterações no padrāo de metilação do DNA foram correlacionadas com diversos processos em mamlferos, incluindo a expressão de genes, a estrutura da cromatina, a replicação do DNA, a impressão genómica parental, uma forma de contole de genes autossômicos em que apenas um dos dois alelos se encontra tanscricionalmente ativo dependendo se este foi herdado do pai ou da mảe, e a inativação do cromossomo $X$ somático no sexo feminino (RAZIN e CEDAR, 1991; 1994; JONES, 1996; ZINGG e JONES, 1997).

Além disso, diversas observações demonstram que a metilação do DNA também desempenha um papel nos processos de diferenciação e proliferação celular e na patogenia do câncer (KANDUC et al., 1991; COUNTS e GOODMAN, 1995; JONES, 1996; ZNGG e JONES, 1997).

Assim, foram observadas amplas alterações no padrão de metilação do DNA de todo o genoma, bem como variações regionais em genes especificos, em uma série de modelos experimentais in vitro e in vivo de carcinogênese (COUNTS e GOODMAN, 1995; JONES, 1996).

Justamente graças a esse motivo tem sido dificil até o momento o estabelecimento de uma relação causa-efeito definitiva entre a mefilação do DNA e a transformação maligna, pois hipometilação global e hipermetilação regional podem coexistir no genoma de uma ampla variedade de cânceres do ser humano e de animais. 
A hipótese implicita nos diversos estudos a respeito da associação entre a metilação do DNA e a carcinogênese é de que a hipometilação de proto-oncogenes elou a hipermetilação de anti-oncogenes alteraria a ligação de fatores de transcrição e a expressão desses genes, promovendo uma vantagem seletiva para a célula iniciada. Portanto, a hipometilaçāo do DNA poderia aumentar a expressão de proto-oncogenes e a hipermetilação silenciar anti-oncogenes (COUNTS E GOODMAN, 1995).

Uma outra alternativa seria de que a hipo ou a hipermetilaçăo poderia levar à transformação maligna através da indução de modificaçōes regionais na conformação do DNA e na estrutura da cromatina. Tais alteraçōes promoveriam uma instabilidade genômica facilitando o acesso de sequências específicas a agentes capazes de lesar o DNA ou tornando a cromatina menos acessivel a fatores de transcriçăo e, portanto, transcricionalmente inativa (LEWIS e BIRD, 1991; RIDEOUT III et al., 1994; ZINGG e JONES, 1997).

Descreve-se também nesse sentido que a perda de citosinas metiladas altera a conformação e a estabilidade da estutura da cromatina através de uma redução nos sitios de ligação para proteinas metil-especificas. Na ausência dessas proteínas as sequências comprometidas do DNA se tornam mais acessiveis à quebra da cadeia do DNA induzida por enzimas ou oxidantes (SZYF et al., 1986; SMITH, 1991; LETEURTRE et al., 1994).

Além disso, sabe-se que a substituição da guanina pela 8-hidroxiguanina, um dos produtos mais prevalentes da lesão do DNA por espécies reativas de oxigênio, altera profundamente a mefilação das citosinas adjacentes, o que sugere um papel para a injúnia oxidativa na formação de padrões aberrantes de metilaçāo do DNA durante a carcinogênese (CERDA e WEITZMAN, 1997).

Portanto, talvez antioxidantes como o $\beta$-caroteno pudessem contribuir para a manutenção de uma metilação adequada do DNA através da capacidade que apresentam de reduzir o estesse oxidativo, e que este fosse, inclusive, um dos mecanismos eventualmente associado com seus efeitos anticarcinogênicos.

Uma das formas de controle do padrão de metilação é através da regulação do gene que codifica para a DNA metiltransferase (DNA MeTase), a enzima que cataliza a transferência de grupamentos metila para o DNA. Aumentos na expressão desse gene caracterizam muitas linhagens de células cancerosas e de pólipos e carcinomas de cólon do ser humano, tendo-se sugerido que esses aumentos poderiam desempenhar um papel na instabilidade genética que caracteriza o câncer e marcar eventos iniciais na transformação celular (EL-DEIRY et al., 1991; ROULEAU et al., 1995).

Observou-se que a região regulatória $5^{\prime}$ do gene para a enzima DNA MeTase possui três sítios de ligação para o fator de transcrição AP-1, podendo ainda este promotor ser induzido pelos proto-oncogenes c-jun ou c-Ha-ras, o que explicaria a hiperatividade dessa enzima observada em muitas linhagens de células cancerosas. Constatou-se, além disso, que a ativação do promotor por c-jun era inibida de modo lígante-dependente pelo receptor para glicocorticóide, sendo portanto provavelmente mediada por interações do tipo proteína-proteina com o fator AP-1 (ROULEAU et al., 1995).

Existe, portanto, a possibilidade de que retinóides e até mesmo o $\beta$-caroteno agora atuando como pró-vitamina $A$, possam vir a interferir da mesma forma que o receptor para glicocorticóide com a ativação do gene para a DNA MeTase através de suas reconhecidas capacidade de transrepressão do fator AP-1 (SALBERT et al., 1993; SILVEIRA e MORENO, 1998), e deste modo também influir na metilação do DNA.

Baseado nessas premissas decidiu-se por avaliar no presente estudo o padrāo de metilação dos proto-oncogenes c-Ha-ras e c-myc, bem como do gene que codifica para a enzima HMGCOA redutase, do figado de ratos Wistar submetidos ao modelo do "hepatócito 
resistente e tratados com óleo de milho, $\beta$-caroteno ou vitamina A durante a fase de progressāo da hepatocarcinogênese.

Optou-se especificamente por tais genes pelo fato de já se ter observado anteriormente que se apresentavam hipometilados em ratos submetidos a diferentes modelos de hepatocarcinogênese (BHAVE ef al., 1988; GARCEA ef al., 1989b; RAO ef al., 1989; MÜNZEL et al., 1991; CONI et al., 1992; ZAPISEK et al., 1992), e devido ao importante papel que seus produtos desempenham tanto na proliferaçăo celular como na carcinogênese (BISHOP, 1991; CONI et al., 1992; MORENO et al., 1995).

O grau de metilação dos genes nas diversas amostras de DNA foi analisado utilizando-se enzimas que detectam a metilação no dimero $C p G$, pois uma citosina 5 ' em relação a uma guanina é de longe o sítio de mefilaçăo mais comum no DNA de animais (ADAMS, 1990).

Empregou-se, para tanto, as enzimas de restriçăo Hpa II e Msp I, capazes de estabelecer diferenças entre sequências metiladas e nāo-metiladas, pois sāo sensivel e insensivel, respectivamente, à presença de um grupamento metila na citosina no interior da sequência CCGG. Portanto, uma banda maior encontrada após digestão com a enzima Hpa ll, e que não é observada após digestão com a enzima Msp I, reflete a presença da metilcitosina em um ou mais sítios CCGG (CmCGG) naquele fragmento de DNA. A redução no número de bandas maiores com o acúmulo de bandas menores após digestāo com a enzima $\mathrm{Hpa}$ ll demonstram a perda progressiva da metilação nos sitios CCGG (ZAPISEK el al., 1992).

Já a presença de bandas únicas após digestāo com a enzima Msp l, em comparação à digestão com a enzima Hpa II, indicam que algumas sequências CCGG no gene em questão se encontravam ainda metiladas (BUSTROS et al., 1988; LIU et al., 1993).

Assim, observou-se no atual estudo padrões de fragmentos de restrição bastante semelhantes entre si em relação a seus números, distribuição por tamanho e intensidade de marcação pela sonda do proto-oncogene c-Ha-ras, após digestão com a enzima Hpa ll de amostras de DNA obtidas tanto de figado de ratos normais não expostos a quaisquer tatamentos, como de lesões hepáticas (nódulos persistentes/cânceres) e áreas aos seus redores consideradas "normais" à macroscopia, de animais submetidos ao modelo do $\mathrm{RH}$ e tratados com óleo de milho (grupo OM - controles), $\beta$-caroteno (grupo $\beta C$ ) ou vitamina $A$ (grupo VA) durante a fase de progressão da hepatocarcinogênese (Figura 6).

Portanto, não foram observadas neste caso alteraçōes dignas de nota no padrāo de metilaçăo do proto-oncogene c-Ha-ras, do DNA de lesões hepáticas (nódulos persistentes/cânceres) obtidas de ratos sacrificados na etapa de progressão da hepatocarcinogênese.

Quando essa mesma membrana foi novamente hibridizada agora com a sonda do protooncogene c-myc (Figura 10) e, subsequentemente, com a sonda para o gene da enzima HMGCoA redutase (Figura 12), constataram-se, entretanto, diferenças facilmente observáveis em relaçāo aos padrōes dos fragmentos de restrição após digestảo do DNA com a enzima Hpa II.

Assim, independente do tratamento a que os animais foram expostos fóleo de milho, $\beta$-caroteno ou vitamina $A$ ), observou-se que as amostras de DNA extraidas das lesões hepáticas (nódulos persistentes/cânceres) resultaram após digestāo com a enzima Hpa II apenas em fragmentos de restrição de pequeno tamanho marcados intensamente pela sonda para o proto-oncogene c-myc, com desaparecimento dos fragmentos maiores constatados nas amostras de figado de ratos normais e de áreas hepáticas ao redor das lesōes (nódulos persistentes/cânceres) consideradas "normais" à macroscopia, de animais submetidos ao modelo do RH (Figura 10).

Também independente do tratamento com óleo de milho, $\beta$-caroteno ou vitamina $A$ a que foram submetidos os diferentes grupos de animais, já após hibridização com a sonda para o gene da enzima HMGCoA redutase constatou-se que estas amostras de DNA colhidas de 
lesōes hepáticas (nódulos persistentes/cânceres) e digeridas com a enzima Hpa II, resultaram em um maior número de fragmentos de pequeno tamanho e marcados mais intensamente, inclusive, do que que nas amostras de DNA dos ratos normais e de áreas consideradas "normais" ao exame macroscópico do figado de animais submeticos 20 modelo do RH (Figura 12).

No caso dos très genes a digestão dos DNAs de nódulos persistentes e cânceres com a enzima Hpa Il resultou em padrões semelhantes de fragmentos de restrição (Flguras 6, $10 \mathrm{e}$ 12). Assim, não houve relação entre o estado de metilaçāo dos mesmos nas sequências CCGG e o fato de se tatar de uma lesão pré-neoplásica ou neoplásica maligna.

Portanto, estes resultados indicam a ocorrência de hipometilação, embora com diferentes graus de intensidade dependendo do gene em questão, nas sequências CCGG do protooncogene c-myc e do gene para a enzima HMGCoA redutase do DNA extraido de nódulos persistentes e cânceres colhidos de ratos na fase de progressão do modelo do RH.

Além disso, sugerem que o padrão de mefilação dos bês genes aqui estudados deve ter sido provavelmente estabelecido em etapas mais iniciais da hepatocarcinogênese que não a progressão, como demonstrado anteriormente embora em modelo utilizando o carcinogênico 1,2-dimetilhidrazina (DMH) como agente iniciante e ácido orótico como promotor em ratos F-344 (RAO et al., 1989).

Como não foram observadas diferenças dignas de nota ente os padrōes dos fragmentos de restrição após digestão com a enzima Hpa ll dos DNAs de nódulos persistentes e cânceres nos três genes em questão, os resultados sugerem, ainda, que variaçōes nos estados de metilação ao menos em suas sequências CCGG correspondentes às respectivas sondas que aqui foram utilizadas, não parecem constituir um fator que possa contribuir efetivamente para 0 estabelecimento da malignidade na hepatocarcinogênese. Isto não exclui, entretanto, a possibilidade que alterações especificas da metilação em outros sitios que não os de reconhecimento Hpa Il nos tês genes, possam ter uma contribuição nesse sentido.

Observaçōes semelhantes a essa foram anteriormente relatadas durante a efapa de progressão de modelos de carcinogênese de pele (RAMSDEN et al, 1985) e de figado (BHAVE et al., 1988; ZAPISEK et al., 1992), tendo-se inclusive chegado a conclusões parecidas (RAMSDEN et al., 1985; BHAVE et al., 1988), embora a partir da constataçăo de hipometilação do proto-oncogene c-Ha-ras de papilomas, nódulos de hepatócitos e carcinomas.

Além disso, os resultados sugerem em conjunto que tanto o $B$-caroteno como a vitamina $A$ nāo foram capazes de exercer quaisquer inffuências que pudessem modificar a metilação dos três genes em questão, quando administrados por oito semanas consecutivas durante essa mesma etapa da carcinogênese hepática.

Tais dados estão de acordo com as evidenncias de um recente estudo conduzido em ratos Wistar submetidos a um modelo do RH modificado que empregou como agente iniciante a $\mathrm{DMH}$ e como indutor de hipometilação a 5-azacitidina, e no qual se observou também se observou, agora in vivo, que tanto o $\beta$-caroteno como a vitamina $A$ não exerceram efeitos relevantes sobre a metilação do DNA (SAMPAIO, 1998).

Vale ressaltar a essa altura que os diversos padrões dos fragmentos de restrição observados no presente estudo após digestão dos DNAs com a enzima Hpa ll e marcação com as sondas para os três genes, foram muito semelhantes aos constatados em duas investigações relatadas anteriomente na literatura, e que também analisaram o padrão de metilaçāo dos proto-oncogenes c-Ha-ras e c-myc (RAO et al., 1989) e do gene para a HMGCoA redutase (CONI et al., 1992), do DNA extraido de figado de rato normal, de lesões hepáticas (nódulos persistentes e cânceres) e de áreas "normais" aos seus redores, colhidas de ratos na fase de progressão ou promoçāo tardia mas submetidos, no caso, ao modelo de hepatocarcinogênese "do ácido orótico". 
Nas três instâncias utilizou-se sondas gênicas idênticas e da mesma procedência.

Da mesma forma que no presente estudo, constatou-se nessas duas investigações que as sequências CCGG do DNA extraido de nódulos persistentes ou cânceres se encontravam hipometiladas no proto-oncogene c-myc e no gene pára a enzima HMGCoA redutase, mas nāo no proto-oncogene c-Ha-ras (RAO ef al, 1989; CONI ef al., 1992). Em uma delas observou-se ainda, entretanto, que este último também se encontrava hipometilado embora na sequência GCGC (RAO of al., 1989).

Após digestão agora com a enzima de restriçăo Msp I, constatou-se também no atual estudo padrōes de fragmentos de restriçāo marcados pelas sondas dos proto-oncogenes c-Ha-ras (Figura 7) e c-myc (Figura 11), e do gene para a enzima HMGCoA redutase (Figura 13), bastantes semelhantes entre as amostras de DNA obtidas de ratos normais (colunas a e b) e de áreas hepáticas também consideradas "normais" ao exame MACroscópico (colunas $c$, d e e), bem como de duas amostras de lesōes (nódulo persistentelcâncer) de animais submetidos ao modelo do RH e tratados com $\beta$-caroteno (colunas i e l) ou vitamina A (colunas $m$ e o).

Estes padrōes de fragmentos de restrição ainda apresentaram no caso desses três genes (Figuras 7, 11 e 13), em comparação com aqueles produzidos após digestão dessas mesmas amostras de DNA com a enzima Hpa II (Figuras 6, 10 e 12) um maior número de bandas de menor tamanho.

Além disso, observou-se nas tês amostras de lesões hepáticas (nódulo/cànceres) e em duas (nódulo/câncer; colunas f, $g$ e h) de animais tratados com $\beta$-caroteno (coluna j) ou vitamina A (coluna $\mathrm{n}$ ), respectivamente, também padrões de fragmentos de restrição após digestão com a enzima Msp I bastante semelhantes entre si, diferindo das amostras de DNA de tecidos normais por apresentarem bandas de menor tamanho e marcadas mais intensamente pelas sondas para os tês genes (Figuras 7, 11 e 13), bem como com desaparecimento, inclusive, de fragmentos de maior tamanho.

Padrões de fragmentos de restrição semelhantes aos destas cinco amostras de lesões hepáticas (colunas $\mathbf{f}, \mathbf{g}, \mathbf{h}, \mathbf{j}$ e $\mathbf{n}$ ) foram também observados em investigaçāo descrita anteriormente na literatura após hibridização das sondas para os proto-oncogenes c-Ha-ras e c-myc, com os DNAs extraídos de nódulos persistentes ou cânceres e digeridos com a enzima Msp I. Nesse caso também se constatou, entretanto, esse mesmo padrão nas amostras de DNA extraidas de rato nomal nāo exposto a qualquer tatamento ou mesmo de áreas hepáticas ao redor das lesões (nódulos/cânceres) de animais submetidos a modelo de hepatocarcinogênese (RAO et al., 1989).

Não se encontrou uma explicação plausivel que pudesse esclarecer as diferenças observadas no presente estudo em relação aos padrões dos fragmentos de restrição após digestão com a enzima Msp 1 do DNA dessas cinco amostras de lesões hepáticas e aqueles constatados em tecidos de rato normal e de áreas hepáticas "normais" ao redor das lesões.

Nesse sentido, possibilidades a serem consideradas incluiriam diferenças em relação à digestão com a enzima de restrição, o que não parece muito admissivel, e que no caso teria sido mais efefiva especificamente em cinco amostras de DNA extraido de lesões hepáficas, de um total de catorze incluindo cinco de DNA extraido de tecidos considerados "normais" e quatro outras de DNA também extraído de lesões, duas de animal tratado com $\beta$-caroteno e duas com vitamina $A$.

Nesse ultimo caso poder-se-ia também aventar que as quatro amostras de lesões hepáticas (2 de nódulos persistentes e 2 de cânceres) estivessem eventualmente "contaminadas" pela presença de tecido "normal" a seus redores, incluido inadvertidamente por ocasião do sacrificio dos animais, o que takvez púdesse ter resultado em um padrão de fragmentos de restição semelhante ao de tecidos normais (Figuras 7,11 e 12). Entretanto, vale aqui lembrar que o DNA extraido dessas amostras foi também utilizado simultaneamente para a digestāo com a enzima 
de restrição Hpa II e subsequente hibridizaçâo com os tês genes (Figuras 12, 10 e 12\}, tendo-se constatado nas tês instâncias padrōes de restriçāo para as quatro amostras semelhantes aos das outras amostras de lesões hepáticas e idênticos aos observados e descritos anteriormente na literatura (RAO ef al., 1989; CONl et al., 1992).

De qualquer modo, esses resultados controversos constatados no presente estudo após digestão dos DNAs com a enzima de restrição Msp I, não invalidam os observados após digestāo dos mesmos com a enzima Hpa ll. Assim, por exemplo, pode-se observar na literatura publicações de estudos procurando esclarecer o estado de metilação de determinados genes durante a hepatocarcinogênese, realizados tāo somente com enzimas de restrição sensiveis à presença do grupamento metila na citosina tais como a Hpa Il ou Hhal (CONI et al., 1992).

Da mesma forma que em relação à proliferaçăo celular, evidências sugerem que alterações na metilação do DNA desempenham um importante papel no processo geral da carcinogênese.

Os resultados do presente estudo demonstram que ocorre de fato hipometilação de genes especificos durante a etapa de progressão, ou seja, no caso, do proto-oncogene c-myc e do gene para a enzima HMGCoA redutase cujos produtos se correlacionam positivamente com a síntese do DNA e a proliferação celular, e que tanto o $\beta$-caroteno como a vitamina $A$ não foram capazes de alterar esse padrão de metilação dos dois genes quando administrados durante oito semanas consecutivas nessa mesma etapa da hepatocarcinogênese.

Portanto, isto sugere que os efeitos inibitórios do $\beta$-caroteno e da vitamina $A$ observados no presente estudo em lesões pré-neoplásicas e neoplásicas, bem como na proliferaçāo celular, não parecem estar relacionados a influências que essas duas substâncias também pudessem eventualmente vir a exercer no processo de metilação do DNA. 


\section{CONCLUSŌES}

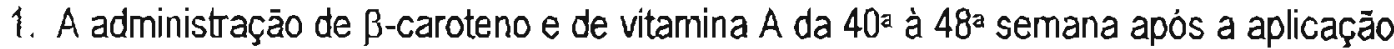
do carcinogênico iniciante diefilnitrosamina (DEN) reduziu a incidência de cànceres observados macroscopicamente e evidenciados ao exame histopatológico de cortes de figado de ratos submetidos ao modelo de hepatocarcinogênese do "hepatócito resistente" $(\mathrm{RH})$. Enquanto esse tratamento por oito semanas consecutivas com o refinóide também reduziu a incidência e o número total de nódulos persistentes de hepatócitos que estes animais ainda apresentavam, 0 mesmo não ocorreu após aplicação do carotenóide pelo mesmo periodo. Tais dados sugerem que as duas substâncias apresentam efeitos inibitórios por ocasião da conversão de nódulos persistentes em cânceres e que apenas a vitamina A é capaz de inibir a evolução dos nódulos ou fazer com que regridam.

2. A administração de $\beta$-caroteno por intubação gástica, em dias alternados e por oito semanas consecutivas durante a etapa de progressão da hepatocarcinogênese, resultou em quantidades mensuráveis do carotenóide, mas não em aumentos significantes de retinol, no figado dos animais submetidos ao modelo do $\mathrm{RH}$. Por outro lado, o tratamento com vitamina $\mathrm{A}$ durante esse mesmo periodo elevou de forma significativa as concentraçōes de retinol, mas não as do carotenóide, no figado dos animais submetidos a esse protocolo de carcinogênese hepática. Tais dados sugerem que os efeitos inibitórios do $\beta$-caroteno e da vitamina $\mathrm{A}$ em nódulos persistentes e cânceres constatados quaando de suas administrações na etapa de progressão, podem ser atribuídos em cada caso a aumentos das concentrações hepáticas do carotenoide ou de retinol. Sugerem ainda que o $\beta$-caroteno è absonido em sua forma integra, e que este teria uma ação intrinseca que poderia estar diretamente relacionada com sua molécula e ser independente de sua funçăo como pró-vitamina $A$.

3. Através da determinação do indice de marcação para a bromodesoxiuridina (BrDU) constatou-se que as lesões hepáticas (nódulos persistentes/cânceres) apresentam maior proliferaçâo de hepatócitos que as áreas teciduais aos seus redores, e que estas demonstram, por sua vez, maior proliferaçāo que tecidos obtidos de figado de ratos não submetidos ao modelo do $\mathrm{RH}$ ou a quaisquer outos tatamentos. Tais dados sugerem que a proliferação celular aumenta à medida que a hepatocarcinogênese evolui.

4. A administração de $\beta$-caroteno e de vitamina $A$ reduziu a proliferação de hepatócitos determinada pelo indice de marcação para a $\mathrm{BrDU}$, tanto em lesões hepáticas (nódulos persistentes/cânceres) como nos tecidos a seus redores. Tais dados sugerem que os efeitos inibitórios em lesð̋es pré-neoplásicas e neoplásicas malignas constatados após aplicação do carotenóide ou do retinóide durante a fase de progressāo da hepatocarcinogênese, podem estar eventualmente relacionados a suas ações inibitórias na proliferação celular. 
5. Após digestāo com a enzima Hoa ll dos DNAs extraidos de nódulos persistentes de hepatócitos e de cânceres obtidos de animais submetidos ao modelo do RH e tatados durante a fase de progressão com óleo de milho, $\beta$-caroteno ou vitamina A, e posterior hibridização com as sondas para os proto-oncogenes $\mathrm{c}$-Ha-ras e c-myc, bem como para o gene que codifica para a enzima HMGCOA redutase, observou-se no caso dos três genes padrões de fragmentos de restrição bastante semelhantes tanto nas lesð̄es pré-neoplásicas como neoplásicas malignas. Tais dados sugerem que o padrão de metilação das sequências CCGG desses três genes já havia sido estabelecido em etapas da hepatocarcinogênese anteriores à fase de progressão. Sugerem ainda que variações na metilação dessas sequências não parecem constituir também no caso dos três genes, em um evento que possa contribuir para o estabelecimento da malignidade na carcinogènese hepática.

6. A administração de $\beta$-caroteno e de vitamina $A$ da $40^{\circledR}$ à $48^{2}$ semana após realização do processo de iniciação com o carcinogênico DEN, não alterou o padrão dos fragmentos de restriçāo observados apos digestāo com a enzima Hpa II dos DNAs extraídos tanto de lesões pré-neoplásicas e neoplásicas como dos tecidos hepáticos a seus redores obtidos de animais submetidos ao modelo do RH, e subsequente hibridizaçāo com as sondas para os genes c-Ha-ras, c-myc e para a enzima HMGCoA redutase. Estes dados sugerem que os efeitos inibitórios em lesões pré-neoplásicas e neoplásicas constatados quando da administração do carotenóide e do retinóide durante a fase de progressão da hepatocarcinogènese, não parecem estar relacionados a influências que estas substâncias poderiam eventualmente exercer no processo de metilação do DNA. 


\section{REFERÊNCIAS BIBLIOGRÁFICAS}

AALTONEN, L. A., PEL TOMÄKI, P., LEACH, F. S., SISTONEN, P., PYLKKĀNEN, L., MECKLIN, J. P. Clues to the pathogenesis of familial colorectal cancer. Science, v. 260, p. 812-816, 1993.

ABBOTT, W. A, MEISTER, A. Intrahepatic transport and utilization of biliary glutathione and its metabolites. Proc. Natt. Acad. So. USA, v. 83, p. 1246-1250, 1986.

ABDEL-FATTH, G. WATZ, 8., HUANG, D., WATSON, R. R Beta-carolene in vitro stimulates tumor necrosis factor alpha and interleukin 1 alpha secrelion by human peripheral blood mononuclear cells. Nutr. Res., v. 13, p. 863-871, 1993.

ACEVEDO, P., BERTRAM, J. Liarozole potentiates the cancer chemopreventive activily and the up-regulation of gap junctional communication and connexin 43 expression by retinoic acid and $\beta$-carotene in 10T1/2 cells. Carcinogenesis, v. 16, p. 2215-2222, 1995.

ADAMS, R. L. P. DNA methylation. The Effect of minor bases on DNA-protein interactions. Biochem. J., v. 265, p. $309-320,1990$.

AGADIR, A, SHEALY, Y. F., HILL, D. L., ZHANG, X -K. Retinyl methyl ether down-regulates activator protein I tanscriptional activation in breast cancer cells. Cancer Res., v. 57, p. 3444-3450, 1997.

AIDOO, A, LYN-COOK, L. E., LENSING, S. WAMER, W. In vivo antimutagenic activity of bela-carolene in ral spleen lymphocytes. Carcinogenesis, v. 16, p. 2237-2241, 1995.

AL-ABDULALY, A. B., SIMPSON, K. L. Reversed-phase flash column chromatography for the determination of retinol in some foods. J. Micronut. Anal, v. 5, p. 161-169, 1989.

ALAM, B. S., ALAM, S. Q. The effect of different levels of dielary B-carotene on DMBA-induced salivary gland tumors. Nutr. Cancer, v. 9, p. 93-101, 1987.

ALBERTS, D. S., GARCIA, D. J. An overview of clinical cancer chemoprevention studies with emphasis on positive phase III studies. J. Nutr., v. 125, p. 692S-697S, 1995.

AMES, B. N. Dietary carcinogenesis and anticarcinogens, oxygen radicals, and degenerative diseases. Science, v. 221, p. 1256-1264, 1983.

AMES, B N., GOLD, L. S. Chemical carcinogenesis: too many rodent carcinogens. Proc. Natt. Acad. Sci. USA, v. 87, p. $7772-7776,1990$.

AMES, B. N., GOLD, L. S., WLLEET, W. C. The causes and prevention of cancer. Proc. Natt. Acad. Sci. USA, v. 92, p. 5258-5265, 1995.

ANILKUMAR, T. V., GOLDING, M., EDWARDS, R. J., LALANI, E. N., SARRAF, C. E., AIISON, M. R. The resistant hepatocyte model of carcinogenesis in the rat the apparent independent development of oval cell proliferation and early nodules. Cancinogenesis, v. 16, p. 845-853, 1995. 
ANZANO, M. A., BYERS, S. W., SMITH, J. M., PEER, C. W., MULLEN, L. T., BROWN, C. C., ROBERTS, A. B., SPORN, M. B. Prevention of breast cancer in the rat with 9-cis-retinoic acid as a single agent and in combination with tamoxifen. Cancer Res., v. 54, p. 4614-4617, 1994.

ANZANO, M. A, PEER, C. W., SMITH, J. M., MULIEN, L. T., SHRADER, M. W., LOGSDON, D. L., DRIVER, C. L., BROWN, C. C., ROBERTS, A B., SPORN, M. B. Chemoprevention of mammary carcinogenesis in the rat combined use of raloxifene and 9-cis-retinoic acid. J. Nat. Cancer Inst, v. 88, p. 123-125, 1996.

APPEL, M. J., WOUTERSEN, R. A. Effects of dietary $\beta$-carotene and selenium on initiation and promotion of pancreatic carcinogenesis in azaserine-treated rats. Carcinogenesis, v. 17, p. 1411-1416, 1996.

ARMSTRONG, G. A, HEARST, J. E. Genetics and molecylar biology of carolenoid pigment biosynthesis. FASEB J., v. 10, p. 228-237, 1996.

ARNOLD, J. T., WILKINSON, B. P., SHARMA, S., STEELE, V. E Evalualion of chemopreventive agenis in different mechanistic classes using a rat tracheal epithelial cell culture transformation assay. Cancer Res., v. 55, p. 537-543, 1995.

ASTORG, P., GRADELET, S., BERGÉS, R., SUSCHETET, M. No evidence for an inhibitory effect of $\beta$-carotene or of canthaxanthin on the inilialion of liver preneoplastic foci by diethylnitrosamine in the rat Nut. Cancer, v. 25, p. 27-34, 1996.

ASTRÖM, A, TAVAKKOL, A., PETERSSON, U., CROMIE, M., ELDER, J. T., VOORHEES, J. J. Molecular doning of two cellular retinoic acid-binding proteins (CRABP). J. Biol. Chem., v. 266, p. 17662-17666, 1991.

ATHAR, M., AGARWAL, R, WANG, Z Y., LLOYD, J. R., BICKERS, D. R., MUKHTAR, H. All-trans relinoic acid protects against conversion of chemically induced and ultaviolet $B$ radiation-induced skin papillomas to carcinomas. Carcinogenesis, v. 12, p. 2325-2329, 1991.

BABA, M., IISHI, H., YAMAMOTO, R., TATSUTA, M. Inhibition by retinoic acid of hepalocarcinogenesis induced by $N$-nitosomorpholine and of expression of myc oncogene protein in Sprague-Dawey rats. int $J$. Cancer, v. 49, p. $467-470,1991$.

BAKER, S. J., MARKOWITZ, S., FEARON, E. R., WILSON, J. K. V., VOGELSTEIN, B. Suppresion of human colorectal carcinoma cell growth by wild-type p53. Science, v. 249, p. 912-914, 1990.

BANNASCH, P. Sequential cellular changes during chemical carcinogenesis. J. Cancer Res. Clin. Oncol, v. 108, p. 11-22, 1984 .

BANNASCH, P. Prerieoplastic lesions as end coints in carcinogericity lesting. I. Hepatic preneoplasia. Carcinogenesis, v. 7, p. 689-695, 1986.

BANNASCH, P., REISS, W. Hislogenese und Cytogenese cholangiocellulärer Tumoren bei Nitosomorpholinvergiffeter Ratten. Zugleich ein Beitrag zur Morphogenese der Cystenleber. Zeit Krebs, v. 76, p. 193-215, 1971.

BANNASCH, P., ZERBAN, H. Tumors of the liver. In: Pathology of Tumors in Laboratory Animals. V. S. TURUSOV, U. MOHR, eds. Lyon, IARC Scientific Publications No. 99, v. 1, p. 199-240, 1990.

BARRET, J. C. Genetic and epigenetic mechanisms of carcinogenesis. In: Mechanisms of Environmental Carcinogenesis. J. C. BARRET, ed. Boca Raton, CRC Press Inc., v. 1, p. 1-15, 1987. 
BARRETI, J.C. Mechanisms of action of known human carcinogens. IARC Sci. Publ, v. 116, p. 115-134, 1992.

BARREIT, J. C. Mechanisms of mullistep carcinogenesis and carcinogen risk assessment. Environ. Health Perspect, v. 100, p. 9-20, 1993.

BARTH, T. J., ZÖLLER, J., KÜBLER, A, BORN, A, OSSWALD, H. Redifferentiation of oral dysplastic mucasa by the application of the antioxidants beta-carotene, $\alpha$-tocopherol and vitarnin C. Int. J. Vitam. Nutr. Res., v. 67, p. 368-376, 1997.

BARUA, A. B. Rebinoyl ß-glucuronide: a biologically active form of vitamin A. Nutr. Rev., v. 55, p. 259-267, 1997.

BASU, T. K., OICKERSON, J. W. T. $\beta$-Carotene and related substances. In: Vitamins in Human Heath and Disease. Wallingford: CAB international, p. 178-192, 1996a.

BASU, T, K., DICKERSON, J. W. T. Vitamin A. In: Vitamins in Human Health and Disease. Wallingford: CAB International, p. 178-192, $1996 \mathrm{~b}$.

BASU, T.K., TEMPLE, N. J., NG, J. Effects of dielary $\beta$-carotene on hepatic drug-metabolizing enzymes in mice. J. Clin. Biochem. Nutr., v. 3, p. 95-102, 1987.

BATRES, R. O, OLSON, J. A A marginal vitarnin A status alters the distribution of vitamin A among parenchymal and stellate cells in rat liver. J. Nutr, v. 117, p. 874-879, 1987.

BAUERNFEIND, J. C. Carotenoid vitamin A precursors and analogs in foods and feeds. J. Agr. Food Chem., v. 20, p. 456-473, 1972

BAUST, C., REDPATH, L, SCHWARZ, E. Different ligand responsiveriess of human retinoic acid receptor $\beta$ gene transcriplion in tumorigenic and nontumorigenic cervical carcinoma-derived cell lines is mediated through a large retinoic acid response domain. Int J. Cancer, v. 67, p. 409-416, 1996.

BEEMS, R. B. The effect of $\beta$-carolene on BP-induced respiratory tract tumors in hamsters. Nutr. Cancer, v. 10, p. 197-204, 1987.

BEESON, W. M. Relative polencies of vitamin A and carolene for animals. Fed. Proc., v. 24, p. 924-926, 1965.

BENDICH, A. The safely of $\beta$-carolene. Nutt. Cancer, v. 11, p. 207-214, 1988.

8ENDICH, A. Carolenoids and the immune response. J. Nutr, v. 119, p. 112-115, 1989.

BENDICH, A, OLSON, J. A. Biological actions of carolenoids. FASEB J., v. 3, p. 1927-1932, 1989.

BENNER, S. Q., HOFMANN, W. J., OTTO, G., PICHLMAYR, R., BANNASCH, P. Human hepatic preneoplasia: phenotypes and proliferation kinetics of foci and nodules of altered hepatocytes and their relationship to liver cell dysplasia. Virchows Arch, v. 431, p. 391-406, 1997.

BENNETT, J. On Cancerous and Cancroid Growths. Edinburgh: Sutherland and Knox, 1849.

BENNIS, F., FAVRE, G., LE GAILLARD, F., SOULA, G. Importance of mevalonate-derived products in the control of HMG-COA reductase activily and growth of human lung adenocarcinoma cell line A549. Int $\mathrm{J}$. Cancer, v. 55, p. 640-645, 1993. 
BERARD, J., LABOUNE, F. MUKUNA, M., MASSE, S., KOTHARY, R, BRADLEY, W. E. Lung tumors in mice expressing and antisense RARß2 transgene. FASEB J, v. 10, p. 1091-1097, 1996.

BERBERIAN, I., CHEN, L. C., ROBINSON, F. R., GLAUERT, H. P., CHOW, C. K, ROBERTSON, L. W. Effect of dielary retinyl palmitate on the promotion of altered hepatic foci by $3,3^{\prime}, 4,4^{\prime}$-tetrachlorobiphenyl and $2,2,4,4,5,5$ '-hexachtorobiphenyl in rats initialed with diethyinitrosamine. Carcinogenesis, v. 16, p. 393-388, 1995 .

BERENBLUM, I., SHUBIK, P. A new, quanitative approach to the study of the stages of chemical carcinogenesis in the mouse's skin. Br. J. Cancer, v. 1, p. 383-386, 1947.

BERTRAM, J. S., KOLONEL, L. N., MEYSKENS JR., F. L. Rationale and st ategies for chemoprevention of cancer in humans. Cancer Res., v. 47, 3012-3031, 1987.

BEX, V., MERCIER, T., CHAUMONTET, C., SANCHEZ, I. G., FLECHON, B., MAZET, F., TRAUB, O., MARTEL, $P$. Reinoic acid enhances connexin 43 expression at the post-transcriptional level in rat liver epithelial œells. Cell Biochem. Function, v. 13, p. 69-77, 1995.

BHAVE, M. R, WILSON, M. J., POIRIER, L. A c-H-ras and c-K-ras gene hypomettylation in the livers and hepatomas of rats fed methyl-deficient, amino acid-defined diels. Carcinogenesis, v. 9, p. 343-348, 1988.

BIANCHI-SANTAMARIA, A, DEL'ORTI, M., FRIGOLI, G., GOBBI, M., ARNABODI, A, SANTAMARIA, L. Beta-carotene storage in rat organs following carrier mediated supplementation. Intemat J. Vit Nutr. Res., v. 64, p. 15-20, 1994.

BIESALSKI, H. K, SCHAFFER, M. Comparative assessment of the activity of beta-carotene, retinoyl-beta-Dglucuronide and retinoic acid growth and differentiation of a human promyelocytic leukemia cell line $\mathrm{HL}-6 \mathrm{O}$. Int J. Vitam. Nutr. Res., v. 67, p. 357-363, 1997.

$\mathrm{BIRD}, \mathrm{A}$. The essertials of DNA methylation. Cell, v. 70, p. 5-8, 1992.

BISHOP, J. M. The molecular genefics of cancer. Science, v. 235, p. 305-311, 1987.

BISHOP, J. M. Molecular themes in oncogenesis. Cell, v. 64, p. 235-248, 1991.

BISHOP, J. M. The discovery of proto-onoogenes. FASEB J., v. 10, p. 362-364, 1996.

BISSCHOP, A, VAN ROOIJEN, L. A, DERKS, H. J., VAN WIJK, R. Induction of rat hepatic omithine decarboxylase by the tumor promotors 12-O-tetradecanoylphortot-13-acetale and phenobarbital in vivo: effect of retinyl-acetate. Carcinogenesis, v. 2, p. 1283-1287, 1981.

BJElKE, E. Dietary vitamin A and human lung cancer. Int J. Cancer, v. 15, p. 561-565, 1975.

BLOCK, G., PATIERSON, B., SUBAR, A Fruit, vegetables, and cancer prevention: a review of the epidemiological evidence. Nutr. Cancer, v. 18, p. 1-29, 1992.

BLOMHOFF, R. Transport and metabolism of vitamin A. Nutr. Rev., v. 52, p. S13-S23, 1994.

BLOMHOFF, R, WAKE, K. Perisinusoidal stellate cells of the liver. important roles in retinol metabolism and fibrosis. FASEB J., v. 5, p. 271-277, 1991. 
BLOMHOFF, R., GREEN, M. H. BERG, T., NORUM, K. R. Transport and storage of vitamin A. Science, v. 250, p. 399-404, 1990a.

BLOMHOFF, R., SKREDE, B., NORUM, K. R. Uptake of chylomicron remnant retynil ester via the low density lipoprotein receptor: implications for the role of vitamin $A$ as a possible preventive for some forms of cancer. J. Intern. Med., v. 228, p. 207-210, 1990 b.

BLOMHOFF, R, GREEN, M. H., GREEN, J. B., BERG, T., NORUM, K. R Vitamin A melabolism: new perspectives on absorption, tansport and storage. Physiol. Rev., v. 71, p. 951-990, 1991.

BLOT, W. J., LI, J. Y., TAYLOR, P. R., GUO, W., DAWSEY, S., WANG, G. Q., YANG, C. S., ZHENG, S. -F., GAL, M., LI, G. -Y., YU, Y., LIU, B. -Q., TANGREA, J., SUN, Y. -H., LIU, F., FRAUMENI JR., J. F., ZHANG, $Y .-H, L L, B$. Nutition intervention trials in Linxian, China: supplementation with specific vitaminumineral combination, cancer incidence, and disease-specific mortality in the general population. J. Nafl. Cancer. inst, v. 85, p. 1483-1491, 1993.

BOHR, V. A, PHILLIPS, D. H. HANAWALT, P. C. Heterogeneous DNA damage and repair in the mammalian genome. Cancer Res., v. 54, p. 6426-6436, 1994.

BOLAG, W. The retinoid revolution. FASEB J., p. 938-939, 1996

BONDI, A, SKLAN, D. Vitamin A and carotene in animal nutition. Prog. Food Nutr, Sci., v. 8, p. 165-191, 1884.

BOONE, C. W. KELLOFF, G. J., MALONE, W. E Identification of candidate cancer chemopreventive agents and their evaluation in animal models and human dinical trials: a review. Cancer Res, v. 50, 0. 2-9, 1990.

BOONE, C. W., KELLOFF, G. J., STEELE, V. E. Natural history of intraepithelial neoplasia in humans with implications for cancer chemoprevention strategy. Cancer Res., v. 52, p. 1651-1659, 1992.

BOREl, P., GROLIER, P. ARMAND, M., PARTIER, A, LAFONT, H., LAIRON, D., AZAIS-BRAESCO, V. Carotenoids in biological emulsions: solubility, surface-to-core distribution, and release from lipid droplets. J. Lipid Res., v. 37, 0. 250-261, 1996.

BOS, J. L. VAN KREIJL, C. F. Genes and gene products that regulate cell proliferation and differentiation: critical targets in carcinogenesis. In: Mechanisms of Carcinogenesis in Risk ldentification. H. VAINIO, P. N. MAGEE, D. B. MCGREGOR, A. J. MCMICHAEL, eds. Intemational Agency for Research on Cancer, Lyon, France, p. 55-65, 1992.

BOWEN, P. E., MOBARHAN, S., SMITH, J. C. Carotenoid absorption in humans. Methods Enzymol., v. 214, p. 3-21, 1993.

BOWEN, P. E. MOBARHAN, S. Evidence from cancer intervention and biomarker studies and the development of biochemical markers. Am. J. Clin. Nutr, v. 62, p. 1403S-1409S, 1995.

BOYLAN, J. F., LUFKIN, T., ACHKAR, C. C., TANEJA, R., CHAMBON, P., GUDAS, L. J. Target disuplion of retinoic acid receptor $\alpha(R A R \alpha$ ) and $R A R \gamma$ results in receptor-specific alterations in retinoic acid-mediated differentiabion and relinoic acid metabolism. Mol. Cell Biol., v. 15, p. 843-851, 1995.

BRALET, M-. P., CALISE, D., BRECHOT, C., FERRY, N. In vivo cell lineage analysis during chemical hepalocarcinogenesis using reboviral-mediated gene transfer. Lab. Invest, v. 74, p. 871-881، 1996. 
BRITTON, G. Stucture and properies of carotenoids in relation to function. FASEB J., v. 9, p. 1551-1558, 1995.

BROWN, M. S., GOLDSTEIN, J. L Suppression of 3-hydroxy-3-melhylglutaryl coenzyme A reduclase activity and inhibition of growth of human fibroblasts by 7-keto-cholesterol. J. Biol Chem . v. 249, p. 7306-7312, 1974.

BRUBACHER, G. B., WEISER, H. The vitamin A activity of $\beta$-carotene. Int J. Vitam. Nut. Res., v. 55, p. 5-15, 1985.

BUKIN, Y. V., ZARIDZE, D. G., DRAUDIN-KRYLENKO, V. A, ORLOV, E. N., SIGACHEVA, N. N. A, DAWEI, F., KURTZMAN, M. Y., SCHLENSKAYA, I. N., GORBACHEVA, O. N., NECHIPAI, A. M., KUVSCHINOV, Y. P., PODDUBNY, B. K., MAXIMOVTCH, D. M. Effect of beta-carotene supplementation on the activily of ornithine decarboxylase (ODC) in stomach mucasa of patients with chronic atrophic gastritis. Eur. J. Cancer Prev, v. 2, p. 61-68, 1993.

BURDON, R. H. Cell proliferation and oxidative stress: basis for anticancer drugs. Proc. Roy. Soc. Edinburgh, v. 99B, p. 169-176, 1992.

BURDON, R. H. Superoxide and hydrogen peroxyde in relation to mammaliam cell proliferation. Free Radic. Biol. Med., v. 18, p. 775-794, 1995.

BURDON, R. H, GILL, V. Celiularty generated active oxygen species and HeLa cell proliferation. Free Radic. Res. Comm., v. 19, p. 203-213, 1993.

BURSCH, W., GRASL-KRAUPP, B., ELLINGER, A, TOROK, L., KIENZ, H., MULAUER, L., SCHULTEHERMANN, R. Active cell death: role in hepatocarcinogenesis and subtypes. Biochem. Cell. Biol., v. 72, p. 669-675, 1994.

BURRI, B. J. Beta-carotene and human health: a review of current research. Nutt. Res, v. 17, p. 547-580, 1997.

BURTON, K. A. A study of the conditions and mechanism of the diphenylamine reaction for the colorimetric estimation of deoxyribonucleic acid. Biochem. J., v. 62, p. 315-323, 1956.

BURTON, G. W. Antioxidants actions of caroternoids. J. Nut., v. 119, p. 109-111, 1989.

BURTON, G. W., INGOLD, K. U. B-Carotene: an unusual type of lipid anboxidant Science, v. 224, p. 569-573, 1984.

BUSTROS, A., NELKIN, B. D., SILVERMAN, A, EHRLICH, G., POIESZ, B., BAYLIN, S. B. The short arm of chromosome 11 is a "hot spot" for hypermethylation in human neoplasia. Proc. Nat. Acad. Sci. USA, v. 85, p. 5693-5697, 1988.

CAHIL, R. J., O'SULLIVAN, K. R., MATHIAS, P. M., BEATTE, S., HAMILTON, H., MORAIN, C. O. Effects of vitamin antioxidant supplementasen on $œ$ ll kinetics of patients with adenomatous polyps. Gut v. 34, p. 963 967, 1993.

CAIRNS, J. The origin of human cancers. Nature, v. 289, p. 353-357, 1981. 
CALIARO, M. J., MARMOUGET, C., GUICHARD, S., MAZARS, P., VALETIE, A, MOISAND, A, BUGAT, R., JOZAN, S. Response of four ovarian carcinoma cell lines to all-trans retinoic acid: relationship with induction of differentiation and retinoic acid receptor expression. Int J. Cancer, v. 56, p. 743-748, 1994.

CAMERON, R. G., ARMSTRONG, D., GUNSEKARA, A, VARGHESE, G., SPEISKY, H. Utilization of circulating glutathione by nodular and cancerous intact rat liver. Carcinogenesis, v. 12, p. 2369-2372, 1991.

CARPENTER, G. Receptors for epidermal growth factor and other polypeptide mitogens. Ann. Rev. Biochem., v. 56, p. 881-914, 1987.

CASEY, G. The role of differentiation in the control of the tumorigenic phenotype. In: Mechanism of Differentiation, P. B. FISHER, ed. Boca Raton, FI. CRC, v. 1, p. 89-116, 1991.

CERDA, S., WEITZMAN, S. A. Influence of oxygen radical injury on DNA methylation. Mutat Res., v. 386, p. 141152, 1997.

CHAMBON, P. A decade of molecular biology of retinoic acid receplors. FASEB J., v. 10, p. 940-954, 1996.

CHANDLER, L. A., SCHWARTZ, S. J. HPLC separation of cis-trans carotene isomers in fresh and processed fruits and vegetables. J. Food Sci., v. 52, 0. 669-672, 1987.

CHEN, C. J., YU, M. W. LIAW, Y. F. Epidemiological characteristics and risk factors of hepatocellular carcinoma. J. Gastroenterol. Hepatol, v. 12, p. S294\$308, 1997.

CHEN, J. Y.., PENCO, S., OSTOWSKI, J., BALAGUER, P., PONS, M., STARRET, J. E, RECZEK, P., CHAMBON, P., GRONEMEYER, $H$. RAR-specific agonistlantagonist which dissociate transactivation and AP-1 transepression inhibit anchorage-independent cell proliferation. EMBO J., v. 1187-1197, 1995.

CHEN, L. -C., SLY, L., JONES, C. S., TARONE, R., OE LUCA, L. M. Differential effects of dietary $\beta$-carolene on papilloma and carcirsoma formation induced by an initiation-promotion protocol in SENCAR mouse skin. Carcinogenesis, v. 14, p. 713-717, 1993.

CHEN, Z -Y, CHENG, Y. -H., WHITE, C. C., EATON, D. L Inhibition of cell proliferation by cyprofibrate in glutathione S-ransferase Pl-1-positive rat hepalic hyperplastic nodules. Cancer Res., v. 54, p. 2622-2629, 1994.

CHIN, D. J., GL, G., RUSSELL, D. W., LISCUM, L., LUSKEY, K. L., BASU, S. K., OKAYAMA, H., BERG, P., GOLDSTEIN, J. L., BROWN, M. S. Nucleotide sequence of 3-hydroxy-3-methylglutaryl coenzyme A reductase, a glycoprolein of endoplasmic reticulum. Nature, v. 308, 0. 613617, 1984.

CHOMIENNE, C., FENAUX, P., DEGOS, L Rebinoid differentiation therapy in promyelocylic leukemia. FASEB J., v. 10, p. 1025-1030, 1996.

CHURCH, S. L., GRANT, J. W., RIDNOUR, L. A, OBERLEY, L. W., SWANSON, P. E., MEL ZER, P. S., TRENT, J. M. Increased manganese superoxide dismutase expression suppresses the malignant phenotype of human melanoma cells. Proc. Natt. Acad. Sci. USA, v. 90, p. 3113-3117, 1993.

CLEVIDENCE, B. A, BIERI, J. C. Association of carotenoids with human plasma lipoproteins. Methods Enzymol, v. 214, p. 33-46, 1993. 
COHEN, S. M., ELLWEIN, L. B. Cell prolferation in carcinogenesis. Science, v. 249, p. 1007-1011, 1990.

COHEN, S. M., ELLWEIN, L. B. Genetic errors, cell proliferation, and carcinogenesis. Cancer Res, v. 51, p. 6493-6505, 1991

COLACCHIO, T. A., MEMOLI, V. A. Chemoprevention of colorectal neoplasms. Ascorbic acid and B-carotene. Arch. Surg., v. 121, p. 1421-1424, 1986.

COLEMAN, W. B., TSONGALIS, G. J. Muitiple mechanisms account for genomic insttability and molecular mutation in neoplastic transformation. Clin. Chem., v. 41, p. 644-657, 1995.

COLUMBANO, A. Cell death: current difficulties in discriminating apoptosis from necrosis in the context of pathological processes in vivo. J. Cell. Biochem., v. 58, p. 181-190, 1995.

COLUMBANO, A, SHINOZUKA, H. Liver regeneration versus direct hyperplasia FASEB J., v. 10, p. 1118$1128,1996$.

COLUMBANO, A, RAJALAKSHMI, S., SARMA, D. S. R. Requirement of cell proliferation for the initiation of liver carcinogenesis as assayed by three different procedures. Cancer Res., v. 41, p. 2079-2083, 1981.

COLUMBANO, A., LEDDA, G. M., RAO, P. M., RAJALAKSHMI, S., SARMA, D. S. R. Dietary orotic acid, a new selective growth stimulus for carcinogen attered hepalocytes in rat Cancer Lett, v. 16, p. 191-196, 1982.

COLUMBANO, A, LEDDA-COLUMBANO, G. M., LEE, G, RAJALAKSHMI, S., SARMA, D. S. R. Inability of mitogen-induced liver hyperplasia to support the induction of enzyme-altered istands induced by liver carcinogens. Cancer Res., v. 47, p. 5557-5559, 1987.

COLUMBANO, A, LEDDA-COLUMBANO, G. M., CURTO, M. ENNAS, G. M., CONI, P., SARMA, D. S. R, PANI, $P$. Cell proffferation and promotion of rat liver carcinogenesis: different effect of hepatic regeneration and milogen-induced hyperplasia on the development of enzyme altered foci. Carcinogenesis, v. 11, p. 771-776, 1990.

COMMITTEE ON DIET, NUTRITON AND CANCER; NATIONAL RESERACH COUNCIL. Washinglon D.C.; National Academy Press, p. 478, 1982.

CONAWAY, C. C., JIAO, D., KELLOFF, G. J, STEELE, V. E, RIVENSON, A, CHUNG, F. L. Chemopreventive potential of tumaric acid, $N$-acolylkysteine, $N$-(4hydroxyphenyi) retinamide and beta-carotene for tobacconitrosarnine-induced lung tumors in AJ mice. Cancer Lett, v. 124, p. 85-93, 1998.

CONI, P., PANG, J., PICHIRI-CONI, G., HSU, S., RAO, P. M., RAJALAKSHMI, S., SARMA, D. S. R. Hypomethylation of $\beta$-hydroxy- $\beta$-methyl-glutaryl coenzyme $A$ reductase gere and its expression during hepatocarcinogenesis in the rat Carcinogenesis, v. 13, p. 497-499, 1992.

CONKLIN, G. Cancer and environment In: Cancer Biology (Readings from Scientific American), E C. FRIEDBERG, ed. San Francisco, Freeman, p. 19-23, 1949.

COPELAND, D. H., SALMON, W. D. The ocurrence of neoplasms in the liver, lungs and other tissues of rats as a result of prolonged choline deficiency. Am. J. Pathol, v. 22, p. 1059-1079, 1946. 
CORRESPONDENCE RE: E. Farber, cell proliferation as a major risk factor for cancer: a concept of doubtul validity. Cancer Res., 55: 3759-3762, 1995, Cancer Res., v. 56, p. 4267-4274, 1996.

COUNTS, J. L., GOODiviN, J. I. Alteration in DNA methylation may play a variety of roles in carcinogenesis. Cell, v. 83, p. 13-15, 1995

CROW, J. A, ONG, D. E. Cell-specific immunohistochemical localization of a cellular rebinol-binding protein (type II) in the small intestine of the rat. Proc. Natt. Acad. Sci. USA, v. 82, 0. 4707-4711, 1985.

CURTHOYS, N. P., HUGHEY, R. P. Characterization and physiological function of rat renal gammaglutamyltanspeptidase. Enzyme, v. 24, p. 383-403, 1979.

DAGLI, M. L. Z Aspectos morfologicos dos figados de ratos tratados com $\beta$-caroteno ou vitamina A e submetidos ao modelo do hepatócito resistente de carcinogênese. São Paulo, 167 p. Tese de Doutorado Faculdade de Medicina Veleninária e Zoolecnia, Universidade de Sāo Paulo], 1994.

DAGLI, M. L. Z., GUERRA, J. L, SINHORINI, I. L., WU, T, S., RIZZ, M. B. S. L., PENTEADO, M. V. C., MORENO, F. S. $\beta$-Carolene reducos the ductular (oval) $œ$ ell reaction in the liver of Wistar rats submitted to the resistant hepatocyte model of carcinogenesis. Pathology, v. 30, p. 259-266, 1998.

DAOUD, A H., GRIFFIN, A C. Elfect of retinoic acid, butylaled hydroxytoluene, selenium, and sorbic acid on azo-dye hepatocarcinogenesis. Cancer Lett, v. 8, p. 299-304, 1980.

DARTIGUES, J. F., DABIS, F. GROS, N., MOISE, A, BOIS, G., SALAMON, R., DILHUYDY, J. M., COURTY, G. Dielary vitamin $A$, beta-carotene and risk of epidermoid lung cancer in south-western France. Eur. J. Epidemiol, v. 6, p. 261-265, 1990.

DARWICHE, N., SCITA, G., JONES, C., RUTBERG, S., GREENWAID, E., TENNENBAUM, T., COLINS, S. J., DELUCA, L. M., YUSPA, S. H. Loss of retinoic acid receptors in mouse skin and skin tumors is associaled with aclivation of the rasto oncogene and high risk for premalignant progression. Cancer Res., v. 56, p. 4942-4949, 1996.

DAVES, B. H. Carotenoids. In; Chemisty and Biochemistry of Plant Pigments. T. W. GOODWIN, ed. Academic Press, London, v. 2, p. 38-165, 1976.

DAVES, R. E. Effect of vilamin A on 7,12-dimethylbenz( $\alpha$ )anthracene-induced papillomas in rhiro mouse skin. Cancer Res., v. 27, p. 237-241, 1967.

DAWSON, M. I., CHAO, W. R., HELMES, L T. Inhibition by retinoids of anthralin induced mouse epidermal ormithine decarboxylase activity and anthralin-prornoted skin tumor formation. Cancer Res., v. 47, p. 6210$6215,1987$.

DEJEAN, A, BOUGUELRET, L., GRZESCHIK, K. -H, TIOLAIS. Hepatitis $B$ virus DNA integration in a sequence homologous to $c-e r b-A$ and steroid receptor genes in a hepatocellular carcinoma Nature, v. 322 , p. 70-72, 1986 .

DE KLERK, N. H., MUSK, A. W., AMBROSINI, G. L., ECCLES, J. L. HANSEN, J., OLSEN, N., WATTS, V. L, LUND, H. G., PANG, S. C., BEILBY, J., HOBBS, M. S. T. Vitamin A and cancer prevention li: comparison of the effects of retinol and $\beta$-carotene. Int J. Cancer, v. 75, p. 362-367, 1998. 
DE LUCA, L. M., SLY, L., JONES, C. S., CHEN, L.-C. Effects of dietary retinoic acid on skin papilloma and carcinoma formation in female SENCAR mice. Carcinogenesis, v. 14, p. 539-542, 1993.

DE LUCA, L. M., DARWICHE, N., CEUI, G., KOSA, K., JONES, C., ROSS, S., CHEN, L.C. Vitamin A in epithelial differentiation and skin carcinogenesis. Nutr. Rev., v. 52, p. S45-S52, 1994.

DE LUCA, L. M., KOSA, K., ANDREOLA, F. The role of vitamin A in differentiation and skin carcinogenesis. $J$. Nutr. Biochem, v. 8, 0. 426-437, 1997.

DE PEE, S., WEST, C. E., MUHILAL, KARYADI, D., HAUTNAST, J. G. A. Lack of improvement in vitamin A status with increased consumption of dark-green leary vegetables. Lancet, v. 346, p. 75-81, 1995

DE RIDDER, L., MOSSEIMANNS, R., BERNAERT, D., GALAND, P. Invasiveness, proliferative activity and ultrastuctural phenotypes from diethylnitrosamine-induced neoplastic nodules and hepatocarcinomas in vitro. Int J. Cancer, v. 40, p. 664668, 1987.

DENDA, A, RAO, P. M., RAJALAKSHMI, S., SARMA, D. S. R. 5-Azacytidine polentiates initiation induced by carcinogens in rat liver. Carcinogenesis, v. 6, p. 145-146, 1985.

DENDA, A, LACONI, E., RAO, P. M., RAJALAKSHMI, S., SARMA, D. S. Sequential histopathological analysis of hepatocarcinogenesis in rats during promotion with orotic acid. Cancer Lett, v. 82, p. 55-64, 1994.

DEUEL JR., H. J., JOHNSTON, C., SUMNER, E., POLGAR, A, ZECHMEISTER, L. Slereochemical configuration and provitamin A activity. I. All-trans-bela-carotene and neo-beta-carotene U. Arch. Biochem., v. 5, p. 107-114, 1944.

DEW, S. E., ONG, D. E. Specificity of the retinol transporter of the rat small intestine brush border. Biochemistry, v. 33, p. $12340-12345,1994$.

DiEHL, A. M., RAI, R. M. Regulation of signal transduction during liver regeneration. FASEB J., v. 10, p. 215-227, 1996.

DINGLE, J. T., LUCY, J. A. Vitamin A, carotenoids and cell function. Biol. Rev. v. 40, p. 422-461, 1965.

DIPPLE, A. DNA adducts of chemical carcinogenesis. Carcinogenesis, v. 16, p. 437-441, 1995.

DOERFLER, W. DNA methylation and gene activity. Annu. Rev. Biochem. v. 52, p. 93-124, 1983.

DOLBEARE, F. Bromodeoxyuridine; a diagnostic tool in biology and medicine, part il: oncology, chemotherapy and carcinogenesis. Histochem. J., v. 27, p. 923-964, 1995.

DOU, R. Strategy for detection of cancer hazards to man. Nature, v. 265, p. 589-596, 1977.

DOLL, R. The lessons of life: Keynoke address to the nutrition and cancer conference. Cancer Res., v. 52, p. 2024s-2029s, 1992.

DOLL, R, PETO, R. The causes of cancer. quantitative estimates of avoidable risks of cancer in the Uniled States today. J. Natt. Cancer Inst, v. 66, p. 1191-1308, 1981. 
DOROGOKUPLA, A. C., TROITZKAIA, E. G., ADILGIREIEVA, L. K., POSTOLNIKOV, S. L., CHEKRYGINA, Z.P. Effect of carolene on the development of induced tumors. Zdravookhr Kazakh, v. 10, p. 32-34, 1973.

DOUGLAS, G. R., ELAKEY, D. H., CLAYSON, D. B. Genotoxicity tests as predictors of carcinogens: an analysis. Mutat Res., v. 196, p. 83-93, 1988.

DRAGAN, Y. P., PITOT, H. C. The role of the stages of initiation and promobion in phenotypic diversity during hepatocarcinogenesis in the rat Carcinogenesis, v. 13, p. 739-750, 1992.

DRAGAN, Y., SARGENT, L., XU, Y. D., XU, Y. H., PITOT, H. The initiation-promotion-progression model of rat hepatocarcinogenesis. Proc. Soc. Exp. Biol. Med, v. 202, p. 16-24, 1993.

DRAGAN, Y. P., HULYY, J. R., NAKAMURA, J., MASS, M. J., SWENBERG, J. A., PITOT, H. C. Biochemical events during initiation of rat hepatocarcinogenesis. Carcinogenesis, v. 15, p. 1451-1458, $1994 \mathrm{a}$.

DRAGAN, Y. P., HULLY, J., CROW, R., MASS, M., PITOT, H. C. Incorporation of bromodeoxyuridine in glutathione S-transierase-positive hepatocyles during rat multisiage hepatocarcinogenesis. Carcinogenesis, v. 15 , p. $1939-1947,19946$.

DRAGAN, Y., TEEGUARDEN, J., CAMPBEL, H., HSIA, S., PITOT, $h$. The quantitation of allered hepatic foci during multistage hepatocarcinogenesis in the rat transforming growth factor $\alpha$ expression as a marker for the stage of progresion. Cancer Lett, v. 93, p. 73-83, 1995.

DRAGAN, Y. P., CAMPBELL, H. A., XU, X -H., PITOT, H. C. Quantitative stereological studies of a "selection" prolocol of hepatocarcinogenesis following initiation in neonatal male and female rats. Carcinogenesis, v. 18, p. 149-158, 1997.

DRAGANI, T. A, MANENTI, G., DELLA PORTA, G. Enhanaing effect of carbon tetrachloride in mouse hepatocarcinogenesis. Cancer Lett, v. 31, p. 171-179, 1986.

DRAGSTED, L. O., STRUBE, M., LARSEN, J. C. Cancer-protective factors in fiuits and vegetables: biochemical and biological background. Pharmacol. Toxicol, v. 72, p. \$116-s135, 1993.

DRINKWATER, N. R. Experimental models and biological mechanisms for tumor promotion. Cancer Cells, v. 2, p. 8-15, 1990.

DUESTER, G. Involvement of alcohol dehydrogenase, short-chain dehydrogenase reductase, aldehyde dehydrogenase and cytochrome P450 in the control of retinoid signaling by activation of retinoic acid synthesis. Biochemisty, v. 35, p. 12221-12227, 1996.

EDES, T. E., THORNTON JR., W. H., SHAH, J. $\beta$-Carotene and aryl hydrocarbon hydroxylase in the rat an effect of $\beta$-carotene independent of vitamin A activity. J. Nut., v. 119, p. 796-799, 1989.

EDES, T. E., GYSBERS, G. G., BUCKLEY, C. S., THORNTON JR., W. H. Exposure to the carcinogen benzopyrene depletes tissue vitamin A. ß-carotene prevents depletion. Nut. Cancer, v. 15, p. 159-166, 1991.

EDWARDS, D. R. Cell signaling and the control of gene transcription. Trends Pharmac. Sci, v. 15, p. 239-244, 1994. 
EGNER, P. A, KENSLER, T. W. Effects of superoxide dismutase on complete and multistage carcinogenesis in mouse skin. Carcinogenesis, v. 6, p. 1167-1172, 1985.

EL-AKAV, Z, NAPOLI, J. L. Rat liver cytosolic retinal dehydrogenase: comparison of 13-cis-, 9-cis-, and alltrans-retinal as substrates and effects of cellular retinoid-binding proteins and relinoic acid on activity. Biochemistry, v. 33, p. 1938-1943, 1994.

EL-BAYOUMY, K, CHUNG, F. L, RICHIE, J. JR, REDDY, 8. S., COHEN, L, WEISBURGER, J., WYNDER, E. L. Dietary control of cancer. Proc. Soc. Exp. Biol. Med., v. 216, p. 211-223, 1997.

EL-GORAB, M., UNDERWOOD, B. A. Solubilization of beta-carotene and retinot into aqueous solutions of mixed micelles. Biochim. Biophys. Acta, v. 306, p. 58-65, 1973.

EL-DEIRY, W. S., NELKIN, B. D., CELANO, P., YEN, R.-W. C., FALCO, J. P., HAMILTON, S. R., BAYLIN, S. B. High expression of the DNA methyitransferase gene characterizes human neoplastic cells and progression slages of colon cancer. Proc. Nat. Acad. Sci. USA, v. 88, p. 3470-3474, 1991.

EMMELOT, P., SCHERER, E. The first relevant cell stage in rat liver carcinogenesis. A quantitative approach. Biochim. Biophys. Acta, v. 605, p. 247-304, 1980.

ENOMOTO, K., FARBER, E. Kinetics of phenotypic maturation of remodeling of hyperplastic nodules during liver carcinogenesis. Cancer Res., v. 42, p. 2330-2335, 1982.

EPSTEIN. J. H. Effects of beta-carotene on ultraviolet induced cancer formation in the hairless mouse skin. Photochem. Photobiol, v. 25, p. 211-213, 1973

ERDMAN JR, J. W, POOR, C. L., DIETZ, J. M. Factors afffecting the bioavailability of vitamin A, carotencids, and vitamin E. Food Tech., v. 42, p. 214-221, 1988.

ERDMAN JR., J. W., BIERER, T. L, GUGGER, E. T. Absorption and transport of carotenoids. Ann. NY Acad. Sci. v. 691, p. 76-85, 1993.

ERLANSON, C., BORGSTOM, B. Identity of vitarnin A esterase activity of rat pancreatic juice. Biochem. Biophys. Acta., v. 167, p. 629-631, 1968.

EVANS, R. M. The steroid and thyroid hormone receptor superfamily. Science, v. 240, p. 889-895, 1988.

EVARTS, R. P., NAGY, P., MARSDEN, E., THORGEIRSSON, S. S. A precursor-product relationship exists between oval cells and hepalocytes in rat liver. Carcinogenesis, v. 8, p. 1737-1740, 1987.

FANJUL, A, DAWSON, M I., HOBBS, P. D., JONG., L, CAMERON, J. F., HARLEY, E., GRAUPNER, G., LU, X P., PFAHL, M. A new class of rebinoids with selective inhibition of AP-1 inhibits proliferation. Nature, v. 372, p. 107-111, 1994.

FARBER, E. Similarities in the sequence of earty histological changes induced in the liver of the rat by ethionine, 2-acelylaminofluorene, and 3"-methyl-4-dimethylaminoazobenzene. Cancer Res., v. 16, p. 142-148, 1956.

FARBER, E. The sequential analysis of liver cancer induction. Biochim. Biophys. Acta, v. 605, p. 149-166, 1980.

FARBER, E. Chemical carcinogenesis. N. Engl. J. Med., v. 305, p. 1379-1389, 1981. 
FARBER, E. The biology of carcinogen-induced hepatocyte nodules and related liver lesions in the rat Toxicol. Pathol, v. 10, p. 197-201, 1982.

FAR8ER, E. Cellular biochemistry of the stepwise development of cancer with chemicals: G. H. A. Clowes Memorial Lecture. Cancer Res., v. 44, p. 5463-5474, 1984a

FARBER, E. Pre-cancerous steps in carcinogenesis: their physiological adaptive nature. Biochim. Biophys. Acta, v. 738, p. $171-180,19846$.

FARBER, E. The biochemistry of preneoplastic liver. a common metabolic pattern in hepatocyte nodules. Can. J. Biochem. Cell Biol, v. 62, p. 486-194, 1984 c.

FARBER, E Clonal adaptation during carcinogenesis. Biochem. Pharmacol., v. 39, p. 1837-1846, 1990.

FARBER, E. Hepalocyte proliferation in stepwise development of experimental liver cell cancer. Dig. Dis. Sci. v. 36, p. 973-978, 1991.

FARBER, E. On cells of origin of liver cell cancer. In: The Role of Cell Types in Hepalocarcinogenesis. A. E. SIRICA, ed. Boca Raton, CRC Press, p. 1-28, 1992.

FARBER, E. Cell proliferation as a major risk factor for cancer. a concept of doubtul validity. Cancer Res., v. 55, p. $3759-3762,1995$.

FARBER, E, CAMERON, R. The sequential anlysis of cancer development Adv. Cancer Res., v. 35, p. 125$226,1980$.

FARBER, E., RUBIN, H. Cellular adaptation in the origin and development of cancer. Cancer Res, v. 51, p. 2751 $2761,1991$.

FARBER, E., SARMA, D. S. R. Hepatocarcinogenesis: a dinamic cellular perspective. Lab. Invest, v. 56, p. 422, 1987.

FARBER, E., PARKER, S., GRUENSTEIN, M. The resistance of putative premalignant liver cell populations, hyperplastic nodules, to the acute cytotoxic effects of some hepatocarcinogens. Cancer Res, v. 36, p. $3879-3887,1976$.

FARBER, E, CHEN, Z -Y., HARRIS, L., LEE, G., RINAUDO, J. S., ROOMI, W. M., ROTSTEIN, J., SEMPLE, E. The biochemical-molecular pathology of the stepwise develooment of liver cancer. new insights and problems. In: Liver Cell Carcinoma. Falk Symposium 51. P. BANNASCH, D. KEPPLER, G. WEBER, eds. Dordrectht, Kluwer Academic Publisters, p. 273-291, 1988.

FEARON, E. R, JONES, P. A. Progressing towards a molecular description of colorectal cancer development FASEB J., v. 6, p. 2783-2790, 1992

FEARON, E. R, VOGELSTEIN, B. A genefic model for colorectal tumorigenesis. Cell, v. 61, p. 757-767, 1990.

FEINBERG, A. P., VOGELSTEIN, B. Hypomethylation distinguishes genes of some human cancers from their normal counlerparts. Nature, v. 301, p. 89-92, 1983a. 
FEINBERG, A. P., VOGELSTEIN, B. A technique for radiolabeling DNA restriction endoruclease fragments to high specific activity. Anal. Biochem., v. 132, p. 6-13, 1983 b.

FEINBERG, A. P., VOGELSTEIN, B. Aơüendum: a lechnique for radiolabeling DNA rostriction endonuctease fragments to high spectic activity. Anal. Biochem. v. 137, p. 266-267, 1984.

FERNANDES-CARLOS, $T$, RIONDEL, J., GLISE, D., GUIRAUD, P., FAVER, A. Modulation of natural killer cell functional acivity in athymic mice by beta-carotene, oestrone and their association. Anticancer Res, v. 17, p. 2523-2527, 1997.

FIALA, S., FIALA, A. E., DIXON, B. Gamma-gitumyl transpeplidase in transplantable, chemically induced rat hepatomas and "spontaneous" mouse hepalomas. J. Nat. Cancer inst, v. 48, p. 1393-1401, 1972.

FiEL, M I., MIN, A, GERBER, M. A., FAIRE, B., SCHWARTZ, M., THUNG, S. N. Hepatocellular carcinoma in long-term oral contraceptive use. Liver, v. 16, p. 372-376, 1996.

FIORELLA, P. D., NAPOLI, J. L. Microsomal retinoic acid melabolism: effects of cellular retinoic acid-binding protein (type I) and C18-hydroxylation as an initial step. J. Biol. Chem., v. 269, p. 10538-10544, 1994.

FIORIO, W. A. B. Aspectos moriológicos e imuno-histoquimicos de figados de ralos tatados com ß-caroteno $\theta$ vitamina A em estágios precoces de carcinogênese, no modelo do hepatócito resistente. Sāo Paulo, 117 p. [Dissertação de Mest ado - Faculdade de Medicina Veterinánia e Zootecnica, Universidade de São Paulo], 1998.

FISHER, D. E. Apoptosis in cancer therapy: crossing the threshold. Cell. v. 78, p. 539-542, 1994.

FISHER, G. J., VOORHEES, J. J. Molecular mechanisms of retinoid actions in skin. FASEB J., v. 10, 0. 10021013,1996 .

FORMELI, F., BARUA, A. B., OLSON, J. A. Bioactivities of N-(4-hydroxyphenyl) retinamide and retinoyl $\beta$ glucuronide. FASEB J., v. 10, p. 1014-1024, 1996.

FOSTER, J. R. The role of cell proliferation in chemically induced carcinogenesis. J. Comp. Path, v. 116, p. 113 144, 1997.

FOULDS, L. The experimental study of tumor progression: a review. Cancer Res., v. 14, p. 327-339, 1954.

FRANGIONI, J. V., MOGHAL, N., STUART-TLLEY, A, NEEL, B. G., ALPER, S. L. The DNA binding domain of retinoic acid receptor $\beta$ is required for ligand-dependent suppression of proliferation. J. Cell Sci., v. 107, p. 827-838, 1994.

FRENKEL, K. Carcinogen-mediated oxidant formation and oxidative DNA damage. Pharmacol. Ther., v. 53, p. 127-166, 1992.

FUHRMAN, B., ELIS, A, AVRAM, M. Hypocholesterolemic effect of lyoopene and $\beta$-carotene is related to suppression of cholesterol synthesis and augmentation of $L D$ receptor activity in macrophages. Biochem. Biophys. Res. Commun., v. 233, p. 658-662, 1997.

FUJIMAKE, Y. Formation of carcinoma in albino rats fed on deficient diets. J. Cancer Res., v. 10, p. 469-477, 1926. 
FURR, H. C., CLARK, R. M. Intestinal absorption and tissue distribution of carotenoids. J. Nutr. Biochem, v. 8, p. $364377,1997$.

GAD, M. Z, HARRISON, E H. Neutral and acid retynil ister hydrolases associated with rat liver microsomes: relationships to microsomal cholesteryl ester hydrolases. J. Lip. Res., v. 32, p. 685-693, 1991.

GAD, S. C., WEIL, C. S. Statistics for toxicologists. In: Principles and Methods of Toxicology. A W. HAYES, ed. Raven Press, New York, p. 435-483, 1989.

GAMA-SOZA, M, SLAGEL, V. A., TREWYN, R W., OXENHANDLER, R., KUO, K. C., GEHRKE, C. W., EHRLICH, M. The 5-methylcytosine content of DNA from human tumors. Nucleic Acids Res., $v .1\}$, p. $6883-6894,1983$.

GANGULY, J., SASTRY,P. S. Mechanism of conversion of $\beta$-carotene into vitamin A - Central cleavage versus random cleavage. World Rev. Nut. Diet, v. 45, p. 199-220, 1985.

GARCEA, R., DAINO, L., PASCALE, R., SIMILE, M. M., PUDDU, M., FRASSETTO, S., COZZOLINO, P., SEDDAIU, M. A. GASPA, L., FEO, F. Inhibition of promotion and persistent nodule growth by S-adenosylL-methionine in rat liver carcinogenesis: role of remodeling and apoptosis. Cancer Res., v. 49, p. 18501856, 1989a.

GARCEA, R., DAINO, L, PASCALE, R., SIMILE, M. M., PUDDU, M., RUGGIU, M. E., SEDDAIU, M. A., SATTA, G., SEQUENZA, M. J., FEO, F. Protoonoogene methylation and expression in regenerating liver and preneoplastic liver nodules induced in the rat by diethylnitosamine: effect of variations of $S$ adenosylmethionine: S-adenosylhomocysteine ratio. Carcinogenesis, v. 10, p. 1183-1192, $1989 \mathrm{~b}$.

GAREWAL, H. S. Antioxidants in oral cancer prevention. Am. J. Clin. Nut., v. 62, p. 1410S-1416S, 1995.

GAZIANO, J. M., JOHNSON, E. J., RUSSELL, R. M., MANSON, J. E., STAMPFER, M. J., RIDKER, P. M., FREI, 8., HENNEKENS, C. H., KRINSKY, N. I. Discrimination in absorption or transport of $\beta$-carotene isomers

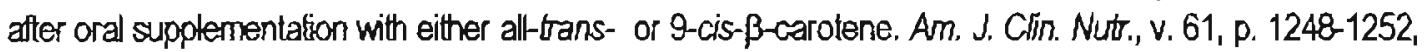
1995.

GEISEN, C., DENK, C., GREMM, B., BAUST, C., KARGER, A, BOLAG, W., SCHWARZ, E. Hightevel expression of the refinoic acid receptor $\beta$ gene expression in normal cells of the uterine cervix is regulaled by the retinoic acid receptor $\alpha$ and is abnomally down-regulated in cervical carcinoma cells. Cancer Res., v. 57, p. $1460-1467,1997$.

GERADTS, J., CHEN, J. -Y., RUSSEU, E. K., YANKASKAS, J. R., NIEVES, L., MINNA, J. D. Human lung cancer cell lines exhibit resitance to relinoic acid treatment. Cell Growth \& Differ, v. 4., p. 799-809, 1993.

GERMAIN, L., NOEL, M., GOURDEAU, H., MARCEAU, N. Promosion of growth and differentiation of ral ductular oval ceils in primary culture. Cancer Res., v. 48, p. 368-378, 1988.

GERSTER, $\mathrm{H}$. Polential role of beta-carotene in the prevention of cardiovasoular disease. Internat J. Vit Nutr. Res., v. 61, 0. 277-291, 1991.

GERSTER, H. Anticarcinogenic effect of common carolenoids. Int J. Vitam. Nutr. Res., v. 63, p. 93-121, 1993. 
GERSTER, $H . \beta$-Carotene, vitamin $E$ and vitamin $C$ in different stages of experimental carcinogenesis. Eur. J. Clin. Nut., v. 49, p. 155-168, 1995.

GERSTER, H. Intermediate cancer biomarkers and their use in beta-carotene studies in humans. Intemat $J$. Vit Nut. Res., v. 66, p. 3-18, 1996.

GERSTER, $K$. The potential role of lycopene for human health. J. Am. Coll Nutr, v. 16, p. 109-126, 1997a.

GERSTER, $H$. Vitamin A - Functions, dietary requirements and safety in humans. Internat $J$. Vitam. Nutr. Res., v. 67, p. 71-90, $1997 \mathrm{~b}$.

GESCHER, A, PASTORINO, U., PLUMMER, S. M. MANSON, M. M. Suppression of tumor development by substances derived from the diet- mechanisms and clinical implications. Br. J. Clin. Phamacol, v. 45, p. 1$12,1998$.

GHOSHAL, A. K., FARBER, E. The induction of liver cancer by dietary deficiency of choline and methionine without added carcinogens. Carcinogenesis, v. 5, p. 1367-1370, 1984.

GIARDELLO, F. M., HAMLTON, S. R., KRUSH, A J., PIANTODOSI, S., HYLIND, L. M., CELANO, P., BOOKER, S. V., ROBINSON, R C., OFFERHAUS, G. J. A Treatment of colonic rectal adenomas with sulindac in familial adenomatous polyposis. N. Engl. J. Med., v. 328, p. 1313-1316, 1993.

GLOVER, J. The conversion of $\beta$-carotene into vitamin A Vitam. Horm., v. 18, p. 371-386, 1960.

GODOY, H. T., RODRIGUEZ-AMAYA, D. 8. Ocurtence of cis-isomers of provitamin A in brazilian fruits. J. Agric. Food Chem., v. 42, p. 1306-1313, 1994.

GOE!HEM, F. V., GHAHROUDI, M. A., CASTELAN, P., KIRSCH-VOLDERS, M. Frequency and DNA content of micronuclei in rat parenchymal liver cells during experimental hepatocarcinogenesis. Carcinogenesis, v. 14, p. 2397-2406, 1993.

GOODMAN, D. S. Overview of current knowiedge of metabolism of vitamin A and carotenoids. J. Natt. Cancer inst, v. 73, p. 1375-1379, 1984.

GOODMAN, D. S., HUANG, H. S. Biosynthesis of vitamin A with rat intestinal enzymes. Science, v. 149, p. 879 $880,1965$.

GOODMAN, D. S., BLOMSTRAND, R., WERNER, B., HUANG, H. S., SHIRATORI, T. The intestinal absorption

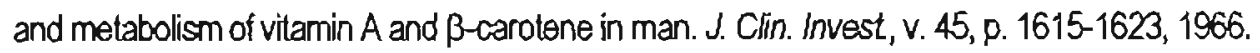

GRADELET, S., ASTORG, P., LE BON, A -M., BERGĖS, R, SUSCHETET, M. Modulation of aflatoxin 81 carcinogenicity, genotoxicity and metabolism in rat liver by dietary carotenoids. evidence for a protective effect of CYP1A inducers. Cancer Lett, v. 114, p. 221-223, 1997.

GRADELET, S., LE BON, A -M., BERGĖS, R., SUSCHETET, M., ASTORG., P. Dietary carotenoids inhibit afiatoxin $B_{1}$-induced liver preneoplastic foci and DNA damage in the rat: role of the modulation of allatoxin $B_{1}$ metabolism. Carcinogenesis, v. 19, p. 403-411, 1998. 
GRASL-KRAUPP, B., BURSCH, W., RUTTKAY-NEDECKY, B., WAGNER, A., LAUER, B., SHULTEHERRMANN, R. Food restriction eliminates preneoplastic cells through applosis and antagonizes carcinogenesis in rat liver. Proc. Natt. Acad. Sci. USA, v. 91, p. 9995-9999, 1994.

GREEN, S., WAHLI, W. Peroxisome proliferator-activated receptors: finding the orphan a home. Mol. Cell. Endocrinol., v. 100, p. 149-153., 1994.

GREENBERG, E. R, BARON, J. A, STUKE, T. A, STEVENS, M. M., MANDEI, J. S., SPENCER, S. K., ELIAS, P. M., LOWE, N., NIERENBERG, D. W., BAYRD, G., VANCE, J. C., FREEMAN, D. H. JR., CLENDENNING, W. E., KWAN, T, and the Skin Cancer Prevention Study Group. A clinical trial of betacarotene to prevent basal-cell and squamous-cell cancers of the skin. New Engl. J. Med., v. 323, p. 789 795, 1990.

GREENBLATT, M. S., BENNET, W. P. HOLLSTEIN, M., HARRIS, C. C. Mutations in the p53 tumor suppressor gene: clues to cancer etiology and molecular pathogenesis. Cancer Res., v. 54, p. 4855-4878, 1994.

GREENWALD, E. D., GREENWALD, E. S. Cancer Epidemiology. Medical Examination Publ. New Hyde Park, New York, 1983.

GRISHAM, J. W., HARTROF, W. S. Morphologic identification by electon microscopy of oval cells in experimental hepatic degeneration. Lab. Invest, v. 10, p. 317-332, 1961.

GROSS, M. D., BISHOP, T. D., BELCHER, J. D., JACOBS JR., D. R. Induction of HL-60 cell differentiation by carotenoids. Nutr. Cancer, v. 27, p. 169-173, 1997.

GUDAS, L J. Relinoids, retinoid-response genes, cell differentiation and cancer. Cell Growth Differ, v. 3, p. $655-$ 662, 1992.

GUDAS, L. J. Retinoids and vertebrate development J. Biol. Chem., v. 269, p. 15399-15402, 1994.

GUDAS, L. J., SPORN, M. B., ROBERTS, A. B. Cellular biology and biochemistry of the retinoids. In: The Retinoids, Biology, Chemistry, and Medicine. M. B. SPORN, A. B. ROBERYS, D. S. GOODMAN, eds. Raven Press Ltd., New York, p. 443-520, 1994.

HAENSZEL, W., KURIHARA, M. Studies of Japanese Migrants. I Mortality from canœer and other diseases among Japanese in the United States. J. Nat. Cancer inst, v. 40, p. 43-68, 1968.

HAENSZE, W., KURIHARA, M., SEGI, M., LEE, R. K. C. Stomach cancer among Japanese in Hawail. J. Nat. Cancer inst, v. 49, p. $969-988,1972$

HANIGAN, M. H., PITOT, H. C. Gamma-glutamyl transpeptidase - its role in hepatocarcinogenesis. Carcinogenesis, v. 6, p. 165-172, 1985.

HANSEN, S., MARET, $W$. Relinal is not formed in vitro by enzymatic cental cleavage of $\beta$-carotene. Biochemistry, v. 27, p. 200-206, 1988.

HAYSTEAD, T. A. J., SIM, A T. R., CARLING, D., HONNOR, R. C., TSUKITANI, Y., COHEN, P., HARDLE, D. G. Effects of the tumor promoter okadaic acid on intracelular protein phosphorylation and metabolism. Nature, v. 337, p. 78-81, 1989. 
HAZZE WOOD, R. N. Carcinogen risk assessment Adv. Food Res., v. 31, p. 1-51, 1987.

HAZUKA, M. B., EDWARDS-PRASAD, J., NEWMAN, I., KINZIE, J. J., PRASAD, K. N. Betacarotene induces morphological differentiation and decreases adenylate cyclase activity in melanoma cells in culture. J. Am. Coll. Nutr, v. 9, p. 143-149, 1990.

HE, Y., ROOT, M. M., PARKER, R. S., COLIN CAMPBELL, T. Effects of carolenoid-rich food extracts on the development of preneoplastic lesions in rat liver and on in vivo and in vitro antioxidant status. Nutr. Cancer, v. 27, p. 238-244, 1997.

HEBUTERNE, $X$, WANG, $X$-D., JOHNSON, E. J., KRINSKY, N. I., RUSSEL, R. M. Intestinal absorption and metabolism of Q-cis- $\beta$-carolene in vivo: biosynthesis of 9-cis-retinoic acid. J. Lipid Res., v. 36, p. 12641273, 1995.

HELGERUD, P., PETERSEN, L. B., NORUM, K. R. Retind esterification by microssomes from the mLeosa of human small intestine. Evidence for acyl-coenzym A retinol acyltransferase activity. J. Clin. Invest., v. 71, p. $747-753,1983$.

HENDERSON, B. E., ROSS, R. K., PIKE, M. C. Toward the primary prevention of cancer. Science, v. 254, p. 1131-1138, 1991.

HENDRICH, S., PITOT, H. C. Enzymes of glutatione metabolism as biochemical makikers during hepalocarcinogenesis. Cancer Metastasis Rev., v. 6, p. 155-178, 1987.

HENDRIKS, H. F. J. Retinoid (vitamin A) metabolism. Eur. J. Clin. Nutr, v. 50, p. S2-S6, 1996.

HENNEKENS, C. H., BURING, J. E., MANSON, J. E., STAMPFER, M. ROSNER, B., COOK, N. R, BELANGER, C., LaMOTTE, F., GAZLANO, J. M., RIDKER, P. M., WILLETT, W. PETO, $R$ Lack of effect of long-term supplementation with beta-carotene on the incidenœ of malignant neoplasms and cardiovascular disease. N. Engl. J. Med., v. 334, o. 1145-1149, 1996.

HENNINGS, H., SHORES, R., WENK, M. L., SPANGLER, E. F., TARONE, R., YUSPA, S. H. Malignant comversion of mouse skin tumors is increased by tumour initiators and unaffected by tumour promoters. Nature, v. 304, p. 67-69, 1983.

HENNINGS, H., SHORES, R., MITCHEl, P., SPANGLER, E. F., YUSPA, S. H. Induction of papillomas with a high probability of conversion to malignancy. Carcinogenesis, v. 6, p. 1807-1610, 1985.

HIGGINS, G. M., ANDERSON, R. M. Experimental pathology of the liver. restoration of the liver of the white rat following parjal surgical removal. Arch. Pathol, v. 12, 0. 186-202, 1931.

HIGGINSON, J, MUIR, C. S. Epidemiology. In: Cancer Medicine. J. F. HOLLAND, E. FREl, eds. Philadelphia, Lea \& Febiger, 1973.

HILL, J. Cautions Against the Immoderate Use of Snuff. London, Baldwin \& Jackson, p. 30, 1761.

HOLLANDER, D., RUBLE JR., P.E. $\beta$-Carotene intestinal absorption: bile, fatty acid, $\mathrm{pH}$, and flow rate effects on

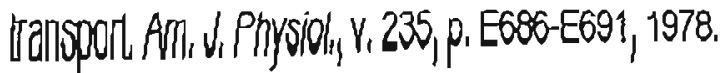


HONG, W. K. ITRI, L. M. Retinoids and human cancer. In: The Retinoids: Biology, Chemistry and Medicine. M. B. SPORN, A. B. ROBERTS, O. S. GOODMAN, eds. Raven Press Lid., New York, 2nd. ed., p. 597-630, 1994.

HONG, W. K., SPORN, M. B. Recent advances in chemoprevention of cancer. Science, v. 278, p. 1073-1077, 1997.

HORIUCHI, S., INOUE, M., MORINO, Y. Gamma-glutamyl transpeptidase: sidedness of its active site on renal brush border membrane. Eur. J. Biochem, v. 87, p. 429-437, 1978.

HOSSAIN, M. Z, ZHANG, L. -X, BERTRAM, J. S. Rebinoids and caroteroids upregulate gap-junctional communication: correlation with enhanced growth control and cancer prevention. Progr. Ceil Res., v. 3, p. 301-309, 1993.

HOULE, B., ROCHETTE-EGLY, C., BRADLEY, W. E. C. Tumor-suppressive effect of the retinoic acid receptor $\beta$ in human epidermoid lung cancer cells. Proc. Nat. Acad. Sci. USA, v. 90, p. 985-989, 1993.

HOWE, J. A., MYMRYK, J. S., EGAN, C., BRANTON, P. E., BAYLEY, S. T. Retinoblasloma growth suppressor and a $300 \mathrm{kD}$ a protein appear to regulate cellular DNA synthesis. Proc. Natt. Acad. Sci. USA, v. 87, p. 58835887,1990 .

HSIA, C. C., THORGEIRSSON, S. S., TABOR, E. Expression of hepatilis B surface and core antigens and transforming growth factor-alpha in "oval cells" of the liver in patients with hepatocellular carcinoma. J. Med. Virol, v. 43, p. 216-221, 1994.

HSU, S. -M., RAINE, L., FANGER, H. A A comparative study of the peroxidase-antiperoxidase method and an avidir-biotin complex method for studying polypeptide hormones with radioimmunoassay anlibodies. Am. J. Clin. Pathol, v. 75, p. 734738, 1981.

HU, L., CROWE, D. L., RHEINWALD, J. G., CHAMBON, P., GUDAS, L. J. Abnormal expression of retinoic acid receptors and keratin 19 by human oral and epidermal squamous cell carcinoma cell lines. Cancer Res., v. 51, 0. 3972-3981, 1991.

HUANG, H. S., GOODMAN, D. S. Vitarnin A and carotenoids. I. Intestinal absorption and metabolism of 14Clabeled vitamin A alcohol and $\beta$-carotene in the rat J. Biol. Chem, v. 240, p. 2839-2844, 1965.

HUANG, M. E., YE, Y. I., CHEN, S. R., CHAI, J. R, LU, J. X, ZHOA, L., GU, L J., WANG, Z Y. Use os all-transretinoic acid in the tratment of acute promielocytic leukemia Blood, v. 72, p. 567-572, 1988.

HUEBNER, R. J., TODARO, G. J. Oncogenes of RNA tumor viruses as determinants of cancer. Proct, Natl. Acad. Sci. USA, v. 64, p. 1087-1094, 1969.

HUFF, J. Issues and controversies surrounding qualitative stategies for identifying and forecasting cancer causing agents in the human environment Pharmacol. Toxicol, v. 72, p. s12-s27, 1993.

HUGHES, D. A., WRIGHT, A. J., FINGLAS, P. M., PEERLESS, A C., BAILEY, A. L., ASTLEY, S. B., PINDER, A C., SOUTHON, S. The effect of betacarotene supplementation on the immune function of blood monocytes from healthy male nonsmokers. J. Lab. Cin. Med., v. 129, p. 309-317, 1997.

HUNTER, T. Oncoprolein networks. Cell, v. 88, p. 333-346, 1997. 
HUNTER, T, PINES, J. Cyclins and cancer It: cyclin D and CDK inhibitors come of age. Cell, v. 79, p. 573-582, 1994.

IMAI, T., MASUI, T., ICHINOSE, M., NAKANISHI, H., YANAI, T., MASEE!, T., MURAMATSU, M., TATEMATSU, M. Reduction of glutathione S-transferase P-form mRNA expression in remodeling nodules in rat liver revealed by in situ hybridization. Carcinogenesis, v. 18, p. 545-551, 1997.

IRVING, C. C. Comparative toxicity of N-hydroxy-2-acetylaminofluorene in several strains of rats. Cancer Res., v. 35, p. 2959-2961, 1975.

IUPAC-IUB JOINT COMMISSION ON BIOCHEMICAL NOMENCLATURE. Nomendature of retinoids. Recommendations 1981. Eur. J. Biochem., v. 129, p. 1-5, 1982.

IWAI, M., KASHIWADANI, M. KITAGAWA, Y., KASHIMA, K., IBATA, Y., YASUDA, K. Immunocytochemical investigation of rat gamma-glutamy! transpeptidase in chemically-induced hepatocarcinogenesis using monoctonal antbody. Arch. Histol. Cytol, v. 57, p. 119-127, 1994.

IYAMA, T., TAKASUGA, A, AZUMA, M. $\beta$-Carotene accumulation in mouse tissues and a protective role zgainst lipid peroxidation. intennat J. Vitam. Nutr. Res., v. 66, p. 301-305, 1996.

JACOBS, T. Control of the cell cycle. Dev. Biol, v. 153, p. 1-15, 1992

JARROUS, N., KAEMPFER, R Induction of human interleukin-1 gene expression by relinoic acid and its regulation at processing of precursor transcripts. J. Biol. Chem., v. 269, p. 23141-23149, 1994.

JENSEN, C. D., HOWES, T. W., SPILLER, G. A, PATTISON, T. S., WHITTAM, J. H., SCALA, J. Observations on the effects of ingesting cis- and trans-beta carotene isomers on human serum concentration. Nut. Rep. Int, v. 35, p. 413-422, 1987.

JETTEN, A. M. Modulation of ceil growth by retinoids and their possible mechanisms of action. Fed. Proc, v. 43, p. $134139,1984$.

JIANG, G., SLADEK, F. M. The DNA binding of hepatocyte nudear factor 4 mediates cooperative, specific binding to DNA and heterodimerization with the retinoid X receptor $\alpha$. J. Biol. Chem., v. 272, p. 1218-1225, 1997.

JONES, P. A. Role of DNA methylation in regulating gene expression, differentiation, and carcinogenesis. in: Mechanisms of Environmental Carcinogenesis. Rote of Genetic and Epigenetic Changes. J. C. BARRET, ed. CRC Press inc., Boca Ralon, vol. I, p. 17-29, 1987.

JONES, P. A. DNA methylation ertors and cancer. Cancer Res, v. 56, p. 2463-2467, 1996.

JONES, P. A, TAYLOR, S. M., MOHANDAS, T., SHAPIRO, L. J. Cell cycle spectic reactivation of an inactive Xchromosome bous by 5-azadeoxycytidine. Proc. Nat. Acad. Sci. USA, v. 80, p. 7586-7590, 1882.

JONES, R. C., SUGIE, S., BRALEY, J., WEISBURGER, J. H. Dietary $\beta$-carotene in rat models of gastrointestinal cancer. J. Nutr., v. 119, p. 508-514, 1989.

JUNQUEIRA, L. C. U., JUNQUEIRA, L. M. M. S. Técnicas Básicas de Citologia e Histologia. Ed. Santos, Săo Paulo, 1983 
JYOTHIRMAYI, R, RAMADAS, K., VARGHESE, C., JACOB, R, NAIR, M. K., SANKARANARAYANAN, R. Efficacy of vilamina $A$ in the prevention of loco-regional recurtence and second primaries in head and neck cancer. Eur. J. Cancer B Oral Oncol, v. 32B, p. 3733376, 1996.

KAGAWA, Y. Impact of westernization on the nutition of Japanese: changes in physique, cancer, longevity and centenarians. Prev. Med., v. 7, p. 205-217, 1978.

KAHL-RAINER, P., MARIAN, B. Retinoids inhibit protein kinase C-dependent transduction of 1,2-diglyceride signals in hurnan colonic turnor cells. Nuts. Cancer, v. 21, p. 157-168, 1994.

KALENGAYI, M. M., RONCHI, G., DESMET, V. J. Histochemisty of gamma-giutamyltanspeptidase in rat liver during aflatoxin 81 induced carcinogenesis. J. Natt. Cancer inst, v. 55, p. 579-588, 1975.

KANDUC, D., ROSSIEUO, M. R., ARESTA, A, CAVAZZA, C., QUAGLIARIELLO, E, FARBER, E. Transitory DNA hypomethylation during liver call proliferation induced by a single dose of lead nitrate. Arch. Biochem. Biophys., v. 286, p. 212-216, 1991.

KARNAUKHOV, V. N. Carotenoids: recent progress, problems and prospects. Comp. Biochem. Physiol, v. 95B, p. $1-20,1990$.

KARRER, P., HELFENSTEIN, A, WEHRL, H., WETTSTEIN, A. Pflanzenfarbstoffe XXV. Uber die konstitution des lycopin und carotins. Heiv. Chim. Acta, v. 13, p. 1084-1099, 1930.

KARRER, P., MORF, R., SCHOEPP, K. Zur Kenntnis des Vitamins A in Fischtranen. Helv. Chim. Acta, v. 14, p. 1431-1436, 1931

KASTNER, $P .$, CHAMBON, $P ., L E I D, M$. Role of nuclear relinoic acid receptors in the regulation of gene expression. In: Vitamin A in Health and Disease, R. BLOMHOFF, ed. Marcel Dekker, New York, p. 189-238, 1994.

KATSUMURA, N., OKUNO, M., ONOGI, N., MARIWAKI, H., MUTO, Y, KOJIMA, S. Suppression of mouse skin papilloma by canthaxanthin and $\beta$-carotene in vivo: possibility of the regression of tumorigenesis by carotenoids without conversion to retinoic acid. Nutr. Cancer, v. 26, p. 203-208, 1996.

KAZ, N., RADVANY, R., OLDHAM, T., KESHAVARZIAN, A. FROMME, T. O., LBERTIN, C., MOBARHAN, S. Immunomodulatory effect of $\beta$-carotene on T lymphocyte subsels in patients with resected colonic polyps and cancer. Nut. Cancer, v. 28, p. 140-145, 1997.

KELOFF, G. J., MALONE, W. F., BOONE, C. W., STEELE, V. E, DOODY, L A Intermediate biomarkers of precancer and their application in chemoprevention. J. Cell. Biochem., v. 16G, p. 15-21, 1992.

KEUOFF, G. J., BOONE, C. W., STEELE, V. E, CROWEU, J. A, LUBET, R. A., GREENWAL, P., HAWK, E. T., FAY, J. R, SIGMAN, C. C. Mechanistic considerations in the evaluation of chemopreventivo data. IARC Sci. Publ, v. 139, p. 203-219, 1996.

KENNAWAY, E. L., HEIGER, I. Carcinogenic substances and their fluorescence spectra. Br. Med. J., v. 1, p. $1044-1046,1930$. 
KEW, M. C., YU, M. C., KEDDA, M. A., COPPIN, A, SARKIN, A., HODKINSON, J. The relative roles of hepatibs $B$ and $C$ viruses in the efiology of hepatocellular carcinoma in southem African blacks. Gastroenterology, v. 112, p. 184-187, 1997.

KHACHIK, F., BEECHER, G. R., LUSBY, W. R. Separation, identification, and quantification of the major carotenoids in extracts of apricots, peaches, cantaloupe, and pink grapefruit by liquid chromatography. J. Agric. Food Chem., v. 37, p. 1465-1473, 1989.

KHACHIK, F., BEECHER, G. R. GOLI, M. G. Separation, idenlification, and quantification of carolenoids in fruits, vegetables and human plasma by high performance liquid chromatography. Pure Appl, Chem., v. 63, p. 71 . 80, 1991.

KHACHIK, F., BEECHER, G. R, SMITH JR, J. C. Lutein, ycopene, and their oxidative metabolites in chernoprevention of cancer. J Cell Biochem. Suppl, v. 22, p. 236-246, 1995.

KHACHIK, F., SPANGLER, C. J., SMITH Jr., J. C., CANFIELD, L. M., STECK, A, PFANDER, H. identification, quantiication, and relative concentrations of carotenoids and their metabolites in human milk and serum. Anal, Chem., v. 69, p. 1873-1881, 1997.

KIRFE, J., KEL TER, M., CANCELA, L. M., PRICE, P. A., SCHÜLE, R. Identification of a novel negative reliroic acid responsive element in the promoter of the human matrix Gla protein gene. Proc. Nat. Acad. Sci. USA, v. 94, p. 2227-2232, 1997.

KITAGAWA, T. Histochemical analysis of hyperplastic lesions and hepatomas of the liver of rats fed N-2fiuorenylacelamide. Gann, v. 62, p. 207-216, 1971.

KITAGAWA, T., PITOT, H. C. The regulation of serine dehydratase and glucose-6-phosphatase in hyperplastic nodules of rat liver during diethylnitrosamine and N-2-fluorenylacetamide feeding. Cancer Res., v. 35, p. $1075-1084,1975$.

KLEIN, G. The approaching era of the tumor suppressor genes. Science, v. 238, p. 1539-1545, 1987.

KOO, L. C. Diet and lung cancer 20 + years later. more questions than answers? int J. Cancer, v. 10S, p. 22-29, 1997.

KRAUPP-GRASL, B., HUBER, W., PUTZ, B., GERBRACHT, U., SCHULTE-HERMANN. Tumor promotion by the peroxisome proliferator natenopin involving a specific sublype of altered foci in rat liver. Cancer Res., v. 50, p. 3701-3708, 1990.

KRINSKY, N. I. Betacarotene: functions. In: New Protective Roles for Selected Nutrients. Alan R. Liss, Inc., p. 1$15,1989 \mathrm{a}$.

KRINSKI, N. I. Carolenoids and cancer in animal models. J. Nutr., v. 119, 123-126, $1989 \mathrm{~b}$.

KRINSKY, N. I. Effects of carotenoids in cellular and animal systems. Am. J. Clin. Nutr., v. 53, p. 238S-246S, 1991.

KRINSKY, N. I. Micronutrients and their influence on mudagenicity and malignant transformation. Ann. New York Acad. Sci, v. 686, p. 229-242, 1993. 
KRINSKY, N. I. The biological properties of carotenoids. Pure \& Appl. Chem. v. 66, p. 1003-1010, 1994.

KRINSKY, N. I., MATHEWS-ROTH, M. M., WELANKIWAR, S., SEHGAL, P. K., LAUSEN, N. C. G., RUSSETT, $M$. The metabolism of [ $\left.{ }^{14} \mathrm{C}\right] ß$-carotene and the presence of other carotenoids in rats and monkeys. J. Nuts., v. 120, p. 81-87, 1990 .

KRUTOVSKIKH, V. A., MESNIL, M., MAZZOLENI, G., YAMASAKI, $K$. Inhibition of rat liver gap junction intercellular communication by tumor-promoting agents in vivo. Lab. Invest, v. 72, p. 571-57, 1995.

LAIRD, P. W., JAENISCH, R. DNA methylation and cancer. Hum. Mol. Genet, v. 3, p. 1487-1495, 1994.

LAKSHMAN, M. R., MYCHKOVSKY, I., ATTLESEY, M. Enzymatic conversion of all-trans- $\beta$-carotene to retinal by a cytosolic enzyme from rabbit and rat intestinal mucosa. Proc. Natt. Acad. Sci. USA, v. 86, p. 9124 9128, 1989

LAMBE, W. Additional Reports on the Effects of a Peculiar Regimen in Cases of Cancer, Scrofula, Consumption, Asthma, and other Chronic Diseases. London: Mawman, 1815.

LAMBERT, L. A. WAMER, W. G., WEI, R. R., LAW, S., CHIRTEL, S. J., KORNHAUSER, A The protective but nonsynergistic effect of dietary $\beta$-carotene and vitamin $E$ on skin tumorigenesis in Skh mice. Nutr. Cancer, v. 21, p. $1-12,1994$.

LAMM, D. L., RIGGS, D. R, SHRIVER, J. S., VANGILDER, P. F., RACH, J. F., DEHAVEN, J. I. Megadose vitamins in bladder cancer. a double-blind dinical trial. J. Urol, v. 151, p. 21-26, 1994.

LANE, D. P. A death in the life of p53. Nature, v. 362, p. 786-787, 1993.

LAWLEY, P. D. Historical origins of current concepts of carcinogenesis. Adv. Cancer Res., v. 65, p. 17-111, 1994.

LE MARCHAND, L., YOSHIZAWA, C. N., KOLONEL, L. N., HANKIN, J. H., GOODMAN, M. T. Vegetable consumption and lung cancer risk: a population-based case-control study in Hawaii. J. Natl. Cancer Inst., v. 81, p. 1158-1164, 1989.

LEDDA-COLUMBANO, G. M., CONI, P., CURTO, M., GIACOMINI, L., FAA, G., SARMA, D. S. R., COL UMBANO, A. Mitogen-induced liver hiperplasia does not substitute for compensatory regeneration during promotion of chemical hepatocarcinogenesis. Carcinogenesis, v. 13, p. 379-383, 1992.

LETTINGA, K. D., GUTIER, W., VANNOORDEN, C. J., F., SCHELLENS, J. P. M., FREDERIKS, W. M. Eariy effects of high doses of retinol (vitamin A) on the in situ cellular metabotism in rat liver. LNer, v. 16, p. 1-11, 1996.

LETEURTRE, F., KOHLHAGEN, G., FESEN, M. R., TANIZAWA, A, KOHN, K. W., POMMIER, Y. Effects of DNA mettylation on topoisomerase I and If cleavage activities. J. Biol. Chem., v. 269, p. 7893-7900, 1994.

LEVIN, G., AMOTZ, A. B., MOKADY, S. Liver accumulation of soluble all-trans of 9-cis $\beta$-carotene in rats and chicks. Com. Biochem. Physiol, v. 107A, p. 203-207, 1994. 
LEVINE, N., MOON, T. E., CARTMEL, B., BANGERT, J. L., RODNEY, S., DONG, Q., PENG, Y. M., ALBERTS D. S. Trials of retinol and isotretinoin in skin cancer prevention: a randomized, double-blind, controlled trial. Cancer Epidemiol. Biomarkers Prev., v. 6., p. 957-961, 1997.

LEWIS, J., BIRD, A. DNA methylation and chromatin structure. FEBS Lett, v. 285, p. 155-159, 1991.

LEWIS, K. C., GREEN, M. H., GREEN, J. B., ZECH, L. A. Retinol metabolism in rats with low vitamin A status: a compartmental model. J. Lipid Res., v. 31, p. 1535-1548, 1990.

LI, J. J., DONG, Z. G., DAWSON, M. I., COLBURN, N. H. Inhibition of tumor promoter-induced transformation by retinoids that transrepress AP-1 without transactivating retinoic acid response element Cancer Res., v. 56, p. 483-489, 1996.

LI, J. -Y, TAYLOR, P. R, LI, B., DAWSEY, S., WANG, G. -Q, ERSHOW, A. G., GUO, W., LIU, S. -F., YANG, C. S., SHEN, Q., WANG, W., MARK, S. D., ZOU, X. -N., GREENWALD, P., WU, Y. -P., BLOT, W. J. Nutrition intervention trials in Linxian, China: multiple vitamin/mineral supplementation " cancer incidence, and disease-specific mortality among adults with esophageal dysplasia. J. Natt. Cancer inst, v. 85, p. 1492 $1498,1993$.

LIANG, F., JASIN, M. Studies on the influence of cytosine methylation on DNA recombination and end-joining in mammalian cells. J. Biol. Chem., v. 270, p. 23838-23844, 1995.

LINDROOS, P. M., ZARNEGAR, R., MICHALOPOULOS, G. K. Hepatocyte growth factor (hepatopoietin A) rapidly increases in plasma before DNA synthesis and liver regeneration stimulated by partial hepatectomy and carbon tetrachloride administration. Hepatology, v. 13, p. 743-750, 1990.

LIPPMAN, S. M., HEYMAN, R. A., KURIE, J. M., BENNER, S. E., HONG, W. K. Retinoids and chemoprevention: clinical and basic studies. J. Cell. Biochem., v. 22, p. 1S-10S, 1995.

LIU, Y., LEE, M -O., WANG, H. -G., LI, Y., HASHIMOTO, Y., KLAUS, M., REED, J.C., ZHANG, X. -K. RARß mediates the growth inhibitory effect of retinoic acid by inducing cell apoptosis in human breast cancer cells. Mol. Cell. Biol., v. 16, p. 1138-1149, 1996.

LODISH, H., BALTIMORE, D., BERK, A, ZIPURSKY, S. L., MATSUDAIRA, P., DARNELL, J. Cancer. Molecular Cell Biology. New York, Scientific American Books, 3d ed., p. 1247-1294, 1995.

LOEB, L. A. Endogenous carcinogenesis: molecular oncology into the twenty-first century - presidential address. Cancer Res., v. 49, p. 5489-5496, 1989.

LOEB, L. A. Microsatellite instability: marker of a mutator phenotype in cancer. Cancer Res., v. 54, p. 5059-5063, 1994.

LOTAN, R. Retinoids in cancer chemoprevention. FASEB J., v. 10, p. 1031-1039, 1996.

LOTAN, R., XU, X -C., LIPPMAN, S. M., RO, J. Y., LEE, J. S., HONG, W. K. Suppression of retinoic acid receptor- $\beta$ in premalignant oral lesions and its up-regulation by isotretinoin. $N$. Engl. J. Med., v. 332, p. $1405-1410,1995$. 
LÖWESTEIN, W. R., ROSE, B. The cell-cell channel in the control of growth. Semin. Cell Biol, v. 3, p. 59-79, 1992.

LUPULESCU, A. Inhibition of DNA synthesis and neoplastic growth by vitamin A (retinol). J. Natl. Cancer Inst., v. 77, p. 149-156, 1986

LUPULESCU, A. The role of vitamins A, $\beta$-caroteno, $E$ and $C$ in cancer biology. Internat J. Vit Nutr. Res., v. 63 , p. 3-14, 1993.

LYU, Y. -W., CHANG, K. -J., LIU, Y. -C. DNA methylation is not involved in growth regulation of gene expression of proliferating cell nuctear antigen. Exp. Cell Res., v. 208, p. 479-484, 1993.

MACDONALD, P. N., ONG, D. E. Binding specificities of cellular retinol-binding protein and cellular relinol-binding protein, type II. J. Biol. Chem., v. 262, p. 10550-10556, 1987.

MACDONALD, P. N., ONG, D. E. Evidenco for a lecithin-retinol acyltransferase activity in the rat small intestine. J. Biol. Chem, v. 263, p. 12478-12482, 1988.

MACK, D. O., REED, V. L., SMITH, L. D. Relinyl acetate inhibition of 3'-methyl-4-dimethyl-aminoazobenzene induced hepatic neoplasia. Int J. Biochem, v. 22, p. 359-365, 1990.

MACLENNAN, R., DA COSTA, J., DAY, N. E., LAW, C. H., NG., Y. K., SHANMUGARATNAM, K. Risk factors for lung cancer in Singapure Chinese, a population with high female incidence rales. Int. $J$. Cancer., v. 20, p. $854-860,1977$.

MAGEE, P. N., FARBER, E. Toxic liver injury and carcirogenesis: methylation of rat-liver nucleic acids by dimethylnitosamine in vivo. Biochem. J., v. 83, p. 114124, 1962.

MAHLEY, R. W., HUSSAIN, M. M. Chylomicron and chylomicron remnant catabolism. Curr. Opin. Lipidol., v. 2, p. $170-176,1991$.

MAIORANA, A. GULLINO, P. M. Effect of retinyl acetate on the incidence of mammary carcinomas and hepatomas in mice. J. Nat. Cancer inst, v. 64, p. 655-663, 1980.

MAJIMA, T., TSUTSUMI, M., NISHINO, H., TSUNODA, T., KONISHI, Y. Inhibitory effects of bela-carotene, palm carotene, and green tea polyphenols on pancreatic carcinogenesis initiated by $\mathrm{N}$-nitrosobis(2oxopropil)arnine in Syrian golden hamsters. Pancreas, v. 16, p. 13-18, 1998.

MANGES, A. R., HOLDEN, J. M., BEECHE, G. R, FORMAN, M. F., LANZA, E. Carotenoid content of firits and vegetables: An evaluation of analytic data. J. Am. Diet Assoc., v. 93, p. 284-296, 1993.

MANGEL SDORF, D. J. Vitamin A receptors. Nutr. Rev., v. 52, p. S32-S44, 1994.

MANGELSDORF, D. J., UMESONO, K., KLIEWER, S. A, BORGMEYER, U., ONG, E. S., EVANS, R. M. A direct repeat in the cellular retinol-binding protein type II gene confers differential regulation by $R X R$ and RAR. Cell, v. 66, p. 555-561, 1991.

MANGELSDORF, D. J., UMESONO, K. EVANS, R. M. The relinoid receptors. In: The Retinoids: Biology, Chemisty and Medicine. M. B. SPORN, A. B. ROBERTS, D. S. GOODMAN, eds. Raven Press Lid., New York, 2nd. ed, p. 319-349, 1994. 
MANJESHWAR, S., LACONI, E, RAO, P. M., RAJALAKSHMI, S., SARMA, D. S. R Influence of orotic acid on multistage hepatocarcinogenesis in the rat, resistance of hepatocytes from nodules to the mitoinhibitory effects of orolic acid. Proc. Soc. Exp. Biol. Med., v. 202, p. 25-29, 1993.

MANORAMA, R., CHINNASAMY, N., RUKMINI, C. Effect of palm oil on some hepatic drug-metabolizing enzymes in rats. Food Chem. Toxical, v. 31, p. 583-588, 1993.

MARNETT, L. J. Aspirin and potential role of prostaglandins in colon cancer. Cancer Res, v. 52, p. 5575-5589, 1992.

MARSHALL, H., MORRISON, A. STUDER, M., PÖPPERL, H., KRUMLAUF, R. Retinoids and Hox genes. FASEB J., v. 10, p. 969-978, 1996.

MATHEWS-ROTH, M. M. The carotenoid content of various organs of animals administered large amounts of beta-carotene. Nut. Rep. Int, v. 117, p. 419-423, 1977.

MATHEWS-ROTH, M. M. Antitumor activity of beta-carotene, canthaxanthin and phytoene. Oncology, v. 39, p. 33-37, 1982.

MATHEWS-ROTH, M. M. Carotenoid pigment administration and delay in development of UV-B-induced tumors. Photochem. Photobiol, v. 37, p. 509-511, 1983.

MATHEWS-ROTH, M. M. Carotenoids and cancer prevention - experimental and epidemiological studies. Pure Appl. Chem., v. 57, p. 717-722, 1985.

MATHEWS-RO3H, M. M. Beta-carotene: clinical aspects. In: New Protective Roles for Selected Nutrients. Alan R. Liss, Inc., p. 17-38, 1989.

MATHEWS-ROTH, M. M. Recent progress in the medical applications of carotenoids. Pure Appl. Chem, v. 63, p. 147-156, 1991.

MATHEWS-ROTH, M. M. KRINSKY, N. I. Carotenoid dose level and protection against UV-B induced skin tumors. Photochem. Photobial, v. 42, p. 35-38, 1985.

MATHEWS-ROTH, M. M., KRINSKY, N. I. Carotenoids affect development of UV-B induced skin cancer. Photochem. Photobiol, v. 46, p. 507-509, 1987.

MATSUSHIMA-NISHIWAKI, R., SHIDOJI, Y., NISHIWAKI, S., YAMADA, T., MORIWAKI, H., MUTO, Y. Suppression by carotenoids of microcystin-induced morphological changes in mouse hepatocytes. Lipids, v. 30, p. 1029-1034, 1995.

MAYNE, S. T., PARKER, R. S. Subcellular distribution of dietary ß-carolene in chick liver. Lipids, v. 21, p. 164 $169,1986$.

MAYNE, S. T. Beta-carotene, carotenoids, and disease prevention in humans. FASEB J., v. 10, p. 690-701, 1996.

MAZIN, A. L. Replicalive and postreplicative DNA methylation as a generator of mutations in the cell (a review). Mol. Biol, v. 27, p. 593-602, 1993. 
MCCOLLUM, E. V., DAVS, M. The necessity of certain lipids during growth. J. Biol. Chem., v. 15, p. 167-175, 1913.

MCCORMICK, D. L., HOLISTER, J. L, BAGG, B. J., LONG, R E. Enhancement of murine hepatocarcinogenesis by all-trans-retinoic acid and two synthetic retinamides. Carcinogenesis, v. 11, p. 1605-1609, 1990.

MCLARTY, J. W., HOLIDAY, D. B., GIRARD, W. M., YANAGIHARA, R. H., KUMMET, T. D., GREENBERG, S. D. Betacarotene, vilamin $A$ and lung cancer chemoprevention: results of an intermediate endpoint study. Am. J. Clin. Nutr, v. 62, p. 1431S-1438S, 1995.

MEISTER, A. On the enzymology of amino acid transport Science, v. 180, p. 33-39, 1973.

MEISTER, A. Glutathione, ascorbate and cellular protection. Cancer Res., v. 54, p. 1969S-1975S, 1994.

MELNICK, R. L. Does chemically induced hepatocyte proliferation predict liver carcinogenesis. FASEB J., v. 6, p. 2698-2706, 1992.

MERTZ, J. R., SHANG, E., PIANTEDOSI, R., WEI, S., WOLGEMUTH, D. J., BLANER, W. S. Identification and characterization of a stereospecific human enzyme that catalyzes 9-cis-retinol oxidation. J. Biol. Chem. v. 272, p. 11744-11749, 1997.

MESTRE, J. R., SUBBARAMAIAH, K., SACKS, P. G., SCHANTZ, S. P., TANABE, T., INOUE, $H_{\text {., }}$ DANNENBERG, A J. Retinoids suppress phorbol ester-mediated induction of cyclooxygenase-2 Cancer Res., v. 57, p. 1081-1085, 1997.

MEYDANI, S. N., WU, D., SANTOS, S. M., HAYEK, M. G. Antioxidants and imune response in aged persons: overview of present evidence. Am. J. Clin. Nutr., v. 62, p. 1462S-1476S, 1995.

MEYSKENS JR., F. L., MANETTA, A. Prevention of cervical intrapithelial neoplasia and cervical cancer. Am. J. Cin. Nut, v. 62, p. 1417S-1419S, 1995.

MEYSKENS JR., F. L, LIU, P. Y., TUTHILL, R. J., SONDAK, V. K., FLETCHER, W. S., JEWELL, W. R., SAMLOWSKI, W., BALCERZAK, S. P., RECTOR, D. J., NOYES, D., COSTANZI, J. J. Randomized trial of vitamin $A$ versus observation as adjuvant therapy in high-risk primary malignant melanoma' a Southwest Oncology Group Study. J. Clin. Oncol, 12, p. 2060-2065, 1994.

MIKOL, Y. B., HOOVER, K. L., CREASIA, D., POIRIER, L. A Hepatocarcinogenesis in rats fed methyt-deficient, amino acid defined diets. Carcinogenesis, v. 4, p. 1619-1629, 1983.

$M I L E R, E$. . . MLLER, J. A. Mechanisms of chemical carcinogenesis: nature of proximate carcinogens and interactions with macromolecules. Pharm. Rev., v. 18, p. 805-838, 1966.

MILER, J. A, MILLER, E C. Chemical carcinogenesis. mechanism and approaches to its control. J. Natt. Cancer inst, v. 47, p. V-XN, 1971.

MONTESANO, R., HAINAUT, P., WILD, C. P. Hepatocellular carcinoma: from gene to pubsic health. J. Nat. Cancer inst, v. 89, p. 1844-1851, 1997. 
MOOLGAVKAR, S. H. Carcinogenesis modeling: from molecular biology lo epidemiology. Annu. Rev. Public Health, v. 7, p. 151-169, 1986.

MOON, R. C., MEHTA, R. G. Anticancinogenic effecis of refinoids in animals. Aov. Exp. Med. Biol, v. 206, p. 399$411,1986$.

MOON, R. C., MEHTA, R. G. Chemoprevention of mammary canœer by retinoids. Basic Life Sci, v. 52, p. 213 $224,1990$.

MOON, R. C., GRUBBS, C. J., SPORN, M. B. Inhibition of 7,12-dimethylibenz(a) anthracene-induced mammary carcinogenesis by retinyl acetate. Cancer Res., v. 36, p. 2626-2630, 1976.

MOON, R. C., MEHTA, R. G., RAO, K. V. N. Retinoids and cancer in experimental animals. In: The Retinoids: Biology, Chemisty and Medicine. M. B. SPORN, A. B. ROBERTS, D. S. GOODMAN, eds. Raven Press Ltd., New York, 2nd. ed., p. 597-630, 1994.

MOON, T. E, LEVINE, N., CARTMEL, B., BANGERT, J. L., RODNEY, S., DONG, Q., PENG, Y. -M., ALBERTS, D. S. Effect of retinol in preventing squamous cell skin cancer in moderale-risk subjects: a randomized, double-blind, controlled trial. Cancer Epidemiol. Biomarkers Prev., v. 6, p. 949-956, 1997.

MOORE, A C . GUGGER, E. T, ERDMAN, J. W. Brush border membrane vesicles from rats and gerbils can be utilized to evaluate the intestinal uptake of all-trans and 9-cis beta-carotene. J. Nutr. v. 126, p. 2904-2912, 1996.

MOORE, M. A. MAYER, D., BANNASCH, P. The dose dependence and sequential appearance of putative preneplastic populations induced in the rat liver by stop experiments with NNM. Carcinogenesis, v. 3, p. 1429-1436, 1982.

MOORE, T. Vitamin A and carolene. VI. The conversion of $\beta$-carolene to vitamin $A$ in vivo. Biochem. J., v. 24, p. 692-702, 1930.

MORDAN, L. J. Inhibition by relinoids of platelet growth factor-dependent stimulation of DNA synthesis and cell division in density-arrested C3H 10T1/2 fibroblasis. Cancer Res., v. 49, p. 906-909, 1989.

MORENO, F. S., GHAZARIAN, D. M., SHARMA, R. K., FARBER, E., GHOSHAL, A. K. Free radical generation and DNA alteration in the rat liver by choline deficient diet with 15\% com oil. Proc. Am. Assoc. Cancer Res., v. 31 , p. $143,1990$.

MORENO, F. S., RIZZI, M. B. S. L., DAGLI, M. L. Z, PENTEADO, M. V. C. Inhibitory effects of $\beta$-carotene on preneoplastic lesions induced in Wistar rats by the resistant hepatocyte model. Carcinogenesis, $v .12$, p. $1817-1822,1991$.

MORENO, F. S., WU, T. S., PENTEADO, M. V. C., RIZZI, M. B. S. L., JORDÃO JR., A. A, ALMEIDAMURADIAN, L. B., DAGLI, M. L. Z A comparison of $\beta$-carotene and vitamin $A$ effects on a hepatocarcinogenesis model. Internat J. Vit Nutr. Res., v. 65, p. 87-94, 1995a.

MORENO, F. S., ROSSIELLO, M. R, MANJESHWAR, S., NATH, R., RAO, P. M., RAJALAKSHMI, S., SARMA, D.S. R. Effect of $\beta$-carotene on the expression of 3-hydroxy-3-methylglutaryl coenzyme A reductase in rat liver. Cancer Lett, v. 96, p. 201-208, 1995 b. 
MORI, S. The changes in the paraocular glands which follow the administration of diets low in fal-soluble $A$ with notes of the effects of the same diets on the salivary glands and the mucosa of the larynx and bronchea. Johns Hopkins Hosp. Bull, v. 33, p. 357-359, 1922.

MORSE, M. A., STONER, G. D. Cancer chemoprevention: principles and prospects. Carcinogenesis, v. 14, p. 1737-1746, 1993.

MUKHERJEE, A, AGARWAL, K., AGUILAR, M. A, SHARMA, A Anticlastogenic activity of $\beta$-carolene against cyclophosphamide in mice in vivo. Mutat Res., v. 263, p. 41-46, 1991.

MÜNZE- P. A, PFOHL-LESZKOWICZ, A, RÖHRDANZ, E., KEITH, G., DIRHEIMER, G., BOCK, K. W. Sitespecific hypomethylation of c-myc protooncogene in liver nodules and inhibition of DNA methylation by $\mathrm{N}$ niltosomorpholine. Biochem. Pharmacol, v. 42, p. 365-371, 1991.

MURAKOSH, M., TAKAYASU, J., KIMURA, O., KOHMURA, E., NISHINO, H. Inhibitory effects of a-carotene on proliferation of the human neuroblastoma cell line GOTO. J. Nat. Cancer inst, v. 81, p. 1649-1652, 1989.

MUTO, Y, MORIWAKI, H., NINOMIYA, M., ADACHI, S., SAITO, A., TAKASAKI, K. T., TANAKA, T., TSURUMI, K., OKUNO, M. TOMITA, E, NAKAMURA, T., KOJIMA, T., pelo Hepatoma Prevention Study Group. Prevention of second primary tumors by an acyclic retinoid, polyprenoic acid, in patients with hepalocelular carcinoma. N. Engl. J. Med., v. 334, p. 1561-1567, 1996.

NAGAO, A. OLSON, J. A. Enymatic formation of 9-cis, 13-cis, and all-trans retinals from isomers of $\beta$-carotene. FASEB J., v. 8, p. 968-973, 1994.

NAGASAWA, H., FUJII, Y., KAGEYAMA, Y., SEGAWA, T., BEN-AMOTZ, A. Suppression by beta-carotene-rich algae Dunaliella bardawil of the progression, but not the development, of spontaneous mammary tumors in SHN virgin mice. Anticancer Res., v. 11, p. 713-718, 1991.

NAGPAL, S., ATHANIKAR, J., CHANDRARATNA, R. A S. Separabion of transactivation and AP1 antagonism functions of retinoic acid receptor $\alpha$. J. Biol. Chem., v. 270, p. 923-927, 1995.

NAKAE, D., KOBAYASH, Y, AKAI, H., ANDOH, N., SATOH, H., OHASHI, K., TSUTSUMI, M., KONISHI, Y. Involvement of \&-hydroxyguanine formation in the initiation of rat liver carcinogenesis by low dose levels of N-nitrosodiethylamine. Cancer Res., v. 57, p. 1281-1287, 1997.

NAKSHATRI, $H .$, CHAMBON, $P$. The directly repeated RG(GT)TCA molifs of the rat and mouse ceilular retinolbinding protein genes are promiscuous binding sites for RAR, RXR, HNF-A, and ARP-1 homo- and heterodimers. J. Biol. Chem., v. 269, p. 890-902, 1994.

NAPOLI, J. L. Biosynthesis and metabolism of relinoic acid: roles of CRBP and CRABP in retinoic acid homeostasis. J. Nutr, v. 123, p. 362-366, 1993.

NAPOLI, J. L. Retinoic acid biosynthesis and melabolism. FASEB J., v. 10, p. 993-1001, 1996 z.

NAPOLI, J. L. Biochemical pathways of retinoid tansport, metabolism and signal transduction. Clin. Immunol. immunopathol, v. 80, p. S52-S62, 1996 b.

NAPOLI, J. L., RACE, K. R. Biogenesis of retinoic acid from $\beta$-carotene. J. Biol. Chem., v. 263, p. 17372-1737, 1988. 
NAPOLI, J. L., BOERMAN, M. H. E. M., CHAl, Y. Z, FIORELLA, P. D. Enzymes and binding proteins affecting retinoic acid concentrations. J. Steroid Biochem. Molec. Biol., v. 53, p. 497-502, 1995.

NAVES, M. M. V., MORENO, F. S. $\beta$-Carotene and cancer chemoprevention: from epidemiological associations to cellular mechanisms of action. Nutr. Res., v. 18, p. 1807-1824, 1998 ,

NEWBERNE, P. M. Biological activity of the aflatoxins in domestic and laboratory animals. U.S. Fish Wildife Serv. Res. Rep., v. 70, p. \{31, 1967.

NEWBERNE, P. M., ROGERS, A. E. Aflatoxin carcinogenesis in the rat: an animal model. Am. J. Pathol., v. 72, p. $137-140,1973$ a.

NEWBERNE, P. M., ROGERS, A. E Rat colon carcinomas associated with aflatoxin and marginal vitamin A. J. Nat. Cancer inst, v. 50, p. 439-448, 1973 b.

NEWBERNE, P. M., SUPHAKARN, V. Prevention role of vitamin A on colon carcinogenesis in rats.. Cancer, v. 40, p. 2553-2556, 1977.

NIKAWA, T., SCHULZ, W. A, VAN DEN BRINK, C. E., HANUSCH, M., VAN DER SAAG, P., STAHL, W., SIES, $H$. Efficacy of all-tans- $\beta$-carotene, canthaxanthin, and all-bans-, S-cis-, and 4-oxoretinoic acids in inducing differentiation of an F9 embryonal carcinoma RAR- $\beta$-lac Z reporter cell line. Arch. Biochem. Biophys., v. 316, p. 665-672, 1995.

NOY, N., XU, Z J. Interaction of retinol with binding proteins: implication for the mechanism of uptake by cellis. Biochemisty, v. 29, p. 3878-3883, 1990.

NOY, N., BLANER, W. S. Interactions of retinol with binding proteins: studies with rat cellular retinotbinding protein and rat retinol-binding protein. Biochemisty, v. 30, p. 6380-6386, 1991.

NURSE, P. Ordering S phase and M phase in the cell cycle. Cell, v. 79, p. 547-550, 1994.

OGAWA, K, MEDLINE, A, FARBER, E. Sequential analysis of hepatic carcinogenesis: the comparative architecture of preneoplastic, malignant, prenatal, postnatal and regenerating liver. Br. J. Cancer, v. 40, p. 782-790, 1979a.

OGAWA, K., MEDLINE, A, FARBER, E Sequential analysis of hepatic carcinogenesis: a comparative study of the ultrastucture of preneoplastic, malignant, prenatal, postnatal and regenerating liver. Lab. Invest, v. 41, p. 22-35, 19796 .

OHASH, K., TSUTSUMI, M., TSUJIUCH, T., KOBITSU, K., OKAJIMA, E., NAKAJIMA, Y., NAKANO, $H_{\text {. }}$ TAKAHASHI, $M_{1}$, MORI, $Y_{1,}$ KONISHI, $Y$. Enhancement of $\mathrm{N}$-nitrosodiethylarnine initialed hepatocarcinogenesis caused by a colchicine-induced cell cycle disturbance in partially hepatectomized rats. Cancer Res., v. 56, p. 34743479, 1996.

OHKAWA, K., ABE, T., HATANO, T., TAKIZAWA, N., YAMADA, K., AKADA, K. The facilitated effect of retind on rat hepatocarcinogenesis induced by 3'-methyl-4-dimethylaminoazobenzene. Carcinogenesis, v. 12, p. $2357-2360,1991$.

$\mathrm{OKOH}, \mathrm{C} ., \mathrm{MYCHKOWSKY}, \mathrm{L}$, LAKSHMAN, M. R. Isolation and some properties of a carotenoid-protein complex from rat liver. J. Nut. Biochem., v. 4, p. 569-575, 1993. 
OLIVEIRA, V. N. Atuvidade quimiopreventiva do fenilacetato em modelo de hepatocarcinogênese. São Paulo, 113 p. [Dissertação de Mestrado - Faculdade de Ciências Farmacêuticas, Universidade de São Paulo], 1998.

OLSON, J. A. Provitamin A function of carotenoids: the conversion of $\beta$-carotene into vitamin A. J. Nutr., V. 119, p. 105-108, 1989a.

OLSON, J. A. Biological actions of carotenoids. J. Nutr., v. 119, p. 94-95, 1989b.

OLSON, J. A. Absorption, transport, and metabolismo of carotenoids in humans. Pure \& Appl. Chem., v. 66, p. 1011-1016, 1994a.

OLSON, J. A. Needs and sources of carotenoids and vitamin A. Nutr. Rev, v. 52, p. S67-S73, 19946.

OLSON, J. A Vitamin A, retinoids and carotenoids. In: Modem Nutrition in Health and Disease, M. E. SHILS, J. A. OLSON, M. SHIKE, eds. Lea \& Febiger, Philadelphia, p. 178-209, $1994 \mathrm{c}$.

OLSON, J. A Benefits and liabilities of vitarnin A and carotenoids. J. Nutr., v. 126, p. 1208S-1212S, 1996.

OLSON, J. A, HAYAISHI, O. The enzymatic cleavage of $\beta$-carotene into vilamin A by soluble enzymes of rat liver and intestine. Proc. Nat. Acad. Sci. USA, v. 54, p. 1364-1370, 1965.

OLSON, J. A, KRINSKY, N. I. Introduction: The colorful, fascinating world of the carotenoids: important physiologic modulators. FASEB J., v. 9, p. 1547-1550, 1995.

OMENN, G. S., GOODMAN, G. E., THORNQUIST, M. D., BALMES, J., CULLEN, M. R., GLASS, A., KEOGH, J. P., MEYSKENS JR, F. L., VALANIS, B., WILLIAMS JR., J. H., BARNHART, S., HAMMAR, S. Effects of a combination of beta-carotene and vitamin $A$ on lung cancer and cardiovascular disease. $N$. Engl. J. Med., v. 334, p. 1150-1155, 1996.

OMS. The World Heath Report Geneva: WHO, 1997.

ONG, D. E. Cellular transport and metabolism of vitamin A. roles of the cellular retinoid-binding proteins. Nutr. Rev., v. 52, p. S24-S31, 1994.

OPIE, E. L. The pathogenesis of tumors in the liver produced by butter yellow. J. Exp. Med., v. 80, p. 231-246, 1944.

ORR, I. M. Oral cancer in betel nut chewers in Travancore: its aetiology, pathology and treatment. Lancet, v. ii, p. 575-580, 1933.

OSHIMA, J., CAMPISI, J. Fundamentals of cell proliferation: control of the cell cycle. J. Dairy Sci, v. 74, p. 2778 2787, 1991

PALOZZA, P., KRINSKY, N. I. Artioxidant effects of carotenoids in vivo and in vivo: an overview. Methods Enzymol., v. 213, p. 403-420, 1992

PARK, C. K., ISHIMI, Y., OHMURA, M., YAMAGUCHI, M., IKEGAMI, S. Vitamin A and carotenoids stimulate differentiation of mouse osteoblastic œells. J. Nutr. Sci. Vitaminol. v. 43, p. 281-296, 1997. 
PARKER, R. S. Absorption, metabolism, and transport of carotenoids. FASEB J., v. 10, p. 542-551, 1996.

PASCALE, R. M. MARRAS, V. M., SIMILE, M. M., DAINO, L., PINNA, G., BENNATI, S., CARTAM M., SEDDAIU, M. A, MASSARELLI, G., FEO, F. Chemoprevention of rat liver carcinogenesis by S-adenosyHLmethionine: a long term study. Cancer Res., v. 52, p. 4979-4986, 1992.

PASTORINO, U., INFANTE, M., MAIOLI, M., CHIESA, G. BUYSE, M., FIRKET, P., ROSMENIZ, N., CLERICl, M., SORESI, E., VALENTE, M., BELONI, P. A. RAVAS: G. Adjuvant treatment of stage l lung cancer with high-dose vitamin A J. Clin. Oncol, v. 11, 1216-1222, 1993.

PEGG, A.E. Poliamine metabolism and its importance in neoplastic growth as a target for chemotherapy. Cancer Res., v. 48, p. $759-774,1988$.

PELTOMÄKI, P., AALTONEN, L. A, SISTONEN, P., PYLKKĀNEN, L., MECKLIN, J. P., JÄRVNEN, el al. Genetic mapping of a locus predisposing to human colorectal cancer. Science, v. 260, p. 810-812, 1993.

PENTEADO, M. V. C., MINAZZ, R. S., ALMEIDA, L. B. Carotenóides e atividade pró-vitaminica A de folhas de hortaliças consumidas no Norte do Brasil. Rev. Farm. Bioquim. Unív. São Paulo, v. 22, p. 97-102, 1986.

PERAINO, C., FRY, R. J. M., STAFFELD, E. Reduction and enhancement by phenobarbital of hepatocarcinogenesis induced in the rat by 2-acetylaminofluorene. Cancer Res., v. 31, p. 1506-1512, 1971.

PERRY, T. M. The new and old diseases: A study of mortality tonds in the United States, 1900-1969. Am. J. Clin. Pathal, v. 63, p. 453-474, 1975.

PETO, R., DOLL, R., BUCKLEY, J. D., SPORN, M. B. Can dietary $\beta$-carotene materially reduce human cancer rates? Nature, v. 290, p. 201-208, 1981.

PEZ7UTO, J. M. Plant-derived anlicancer agents. Biochem. Pharmacol, v. 53, p. 121-133, 1997.

PHILLIPS, R. L. Role of lifestyle and dielary habits in risk of cancer among Seventh Day Adventists. Cancer Res., v. 35, p. 3513-3522, 1975.

PHILLIPS, R. W., KIKENDALL, J. W., LUK, G. D., WILLIS, S. M., MURPHY, J. R, MAYDONOVTCH, C., BOWEN, P. E., STACEWICZ-SAPUNTZAKIS, WONG, R. K. K. Beta-carolene inhibits rectal mucosa omithine decarboxylase activity in colon cancer patients. Cancer Res, v. 53, p. 3723-3725, 1993.

PINTO, C. B., COLEMAN, M. P. Cancer mortality in Rio de Janeiro. Int J. Cancer, v. 46, p. 173-177, 1990.

PISTOI, S., MORELO, D. Prometheus' myth revisited: transgenic mice as a powertul tool to study liver regeneration. FASEB J., v. 10, p. 819-828, 1996.

PITOT, H. C. Altered hepatic foci: their roie in murine hepatocarcinogenesis. Annu. Rev. Pharmacol. Toxicol., v. 30, p. 465-500, 1990.

PITOT, H. C., DRAGAN, Y. P. Facts and theories conceming the mechanisms of carcinogenesis. FASEB J., v. 5, o. 2280-2286, 1991.

PITOT, H. C. The molecular biology of carcinogenesis. Cancer, v. 72, p. 962-970, 1993. 
PITOT, H. C. The role of receplors in multistage carcinogenesis. Mutat Res, v. 333, p. 3-14, 1995.

PITOT, H. C., BARSNESS, L., GOLDSWORTHY, T., KITAGAWA, T. Biochemical characlerization of slages of hepatocarcinogenesis after a single dose of diethylnitrosamine. Nature, v. 271, p. 456-458, 1978.

PITOT, H. C., DRAGAN, Y. P., TEEGUARDEN, J., HSIA, S., CAMPBELL, H. Quantitation of multistage carcinogenesis in rat fiver. Toxicol. Pathol, v. 24, p. 119-128, 1996.

POIRIER, L. A. Methyl group deficiency in hepatocarcinogenesis. Drug Metab. Rev., v. 26, p. 185-199, 1994.

PONDER, B. A. J. Inheriled predisposition to cancer. Trends Genet, v. 6, p. 213-218, 1990.

PONDER, B. A. J. Molecular genetics of canœr. Br. Med. J, v. 304, p. 1234-1236, 1992

PONDER, K. P. Analysis of liver development, regeneration, and carcinogenesis by genetic marking studies. FASEB. J., v. 10, p. 673-684, 1996.

POOL-ZOBEL, B. L, BUB, A, MÜLLER, H., WOLLOWSKI, I., RECHKEMMER, G. Consumption of vegelables reduces genetic damage in humans. first results of a human intervention tial with carotenoid-rich foods. Carcinogenesis, v. 18, p. 1847-1850, 1997.

POOR, C. L., BIERER, T. L., MERCHEN, N. R., FAHEY, G. C., ERDMAN, J. W. The accumulation of alpha- and beta-carotene in serum and tissues of preruminant calves fed raw and steamed carrot slurries. $J$, Nutr., v. 123, p. 1296-1304, 1993.

POT, P. Chirurgical Observations. London, Hawkes, Clark \& Collins, p. 63, 1775.

POTER, V. R. A new protocol and its rationale for the study of initiation and promotion of carcinogenesis in rat liver. Carcinogenesis, v. 2, p. 1375-1379, 1981.

POUND, A. W., MCGUIRE, L J. Repeated partial hepalectomy as a promoting stimulus for carcinogenic response of liver to nitrosamines in rats. Br. J. Cancer, v. 37., p. 585-594, 1978.

POWIS, G. GASDASKA, J. R., BAKER, A. Redox signaling and the control of cell growth and death. In: Antioxidants in Disease Mechanisms and Therapy. H. SIES, ed. Academic Press, San Diego, p. 329-402, 1997.

PRICE, J. M., HARMAN, J. W., MLLER, E. C., MLLLER, J. A. Progressive microscopic alterations in the livers of rats fed the hepatic carcinogens 3'-methyl-4-dimeshylaminoazobenzene and 4'-fluor-4 dimethylaminoazobenzene. Cancer Res., v. 12, p. 192-200, 1952.

PRIMIANO, T, SUTTER, T. R, KENSLER, T. W. Antioxidant-inducibte genes. In: Antioxidants in Disease Mechanisms and Therapy. H. SIES, ed. Academic Press, San Diego, p. 293-328, 1997.

PUNG, A. O., RUNDHAUG, J. E., YOSHIZAWA, C. N., BERTRAM, J. S. $\beta$-Carolene and canthaxanthin inhibit chemically- and physically-induced neoplastic tansformation in $10 T 1 / 2$ œells. Carcinogenesis, v. 9, p. 1533$1539,1988$.

RAICA, N., SCOTT, J., LOWRY, L., SAUBERLICH, H. E. Vitamin A concentation in human issues collecled fom five areas in the United States. Am. J. Clin. Nuts, v. 25, p. 291-296, 1972. 
RAJALAKSHMI, S., RAO, P. M., SARMA, D. R. S. Studies on carcinogen chromatin-DNA interaction: inhibition of N-methyl-N-nitosourea-induced methylation of chromatin-DNA by spermine and distarmycin A. Biochemistry, v. 17, p. 4515-4518, 1978.

RAJALAKSHMI, S., RAO, P. M., SARMA, D. S. R. Chemical carcinogenesis: interaction of carcinogens with nucleic acids in: Cancer. a Comprehensive Treatise. F. F. BECKER, ed. New York, Plenum Press, 2d. ed., vol. 1, p. 335, 1982.

RAMAZINI, B. Oiseases of workers. (Tradução do texto latino por Wilmer Cave Wright). Chicago, University of Chicago Press, p. 191, 1940.

RAMSDEN, M, COLE, G., SMITH, J, BALMAIN, A. Differential methylation of the c-H-ras gene in normal mouse cells and during skin tumour progression. EMBO J., v. 4, p. 1449-1454, 1985.

RAO, M. N., GHOSH, P. LAKSHMAN, M. R. Purification and partial characterization of a cellular carotenoidbinding protein thom ferret tiver. J. Biol. Chem., v. 272, p. 24455-24460, 1997.

RAO, M. S., REDDY, J. K. Peroxisome proliferation and hepatocarcinogenesis. Carcinogenesis, v. 8, p. 631-636, 1987.

RAO, P. M., NAGAMINE, K., HO, R. K., ROOMI, M. W., LAURIER, C., SARMA, D. S. R. Dielary orotic acid enhances the incidence of $\gamma$-giutamyltansferase positive foci in rat liver induced by chemical carcinogens. Carcinogenesis, v. 4, p. 1541-1545, 1983.

RAO, P. M., ANTONY, A, RAJALAKSHMI, S., SARMA, D. S. R. Studies on hypomettyiation of liver DNA during early stages of chemical carcinogenesis in rat liver. Carcinogenesis, v. 10, p. 933-937, 1989.

RAPPAPORT, A M., BOROWY, Z J., LOUGHEED, W. M., LOTTO, W. N. Subdivision of hexagonal liver tobules into a structural and functional unit Role in hepatic physiology and pathology. Anat Rec., v. 119, p. 11-27, 1954.

RAZIN, A, CEDAR, H. ONA methylation and gene expression. Microbiol. Rev., v. 55, p. 451-458, 1991.

RAZIN, A, CEDAR, H. DNA methylation and genomic imprinting. Cell. v. TI, p. 473-476, 1994.

REDDY, B. S. Micronutients as chemopreventive agents. IARC Sci. Publ, v. 139, p. 221-235, 1996.

REDDY, G. P. V. Cell cycle: regulatory events in G1 - transition of mammalian cells. J. Cell. Biochem., v. 54, p. 379-386, 1994.

REDDY, J. K, RAO, S. Peroxisome proliferation-related oxidative stress and hepatocancinogenesis In: Anticarcinogenesis and Radiation Protection. P. A. CERUTTI, O. F. NYGAARD, M.G. SIMIC, eds. New York, Plenum Press, p. 85-91, 1987.

REDDY, J. K., AZARNOFF, D. L. HIGNITE, C. E Hypolipidaemic hepatic peroxisome proliferators form a novel class of chemical carcinogens. Nature, v. 283, p. 397-398, 1980.

RENNER, H. W. Anticlastogenic effect of $\beta$-carotene in Chinese hamsters. Time and dose-response studies with different mulagens. Mutat Res., v. 144, p. 251-256, 1995. 
RETTENMAJER, R., SCHUEP, W. Determination of vilamins $A$ and $E$ in liver tissue. Int. J. Vitam. Nutr. Res., v. 62, p. 312-317, 1992

RETTURA, G., STRATFORD, F., LEVENSON, S. M., SEIFTER, - - - Prophylactic and therapeutic actions of supplemental $\beta$-carotene in mice inoculated with C3HBA adenocarcinoma $œ$ lls: lack of therapeutic action of supplemental ascorbic acid. J. Nat. Cancer inst, v. 69, p. 73-77, 1982.

REUBER, M. D. Development of preneoplastic and neoplastic lesions of the liver in male rals given $0.025 \% \mathrm{~N}-2$ fluorenyldiacetamide. J. Natt. Cancer Inst, v. 34, p. 697-723, 1965.

RIBAYA-MERCADO, J. D., HOLMGREN, S. C., FOX, J. G., RUSSELL, R. M. Dielary $\beta$-carotene absorption and metabolism in ferrets and rats. J. Nut., v. 119, p. 665-668, 1989.

RIDEOUT III, W. M., EVERSOLE-CIRE, P., SPRUCK III, C. H., HUSTAD, C. M., COETZEE, G. A, GONZALES, F. A, JONES, P. A Progressive increases in the methylation status and heterochromatinization of the myoD CpG istand during oncogenic transformation. Mol. Cell. Biol, v. 14, p. 6143-6152, 1994.

RIEDER, A, ADAMEK, M., WRBA, $H$. Delay of diethylnitrosamine-induced hepaloma in rats by carrol feeding. Oncotogy, v. 40, 120-123, 1983 .

RIGTRUP, K. M., MCEWEN, L. R., SAID, H. M., ONG, D. E. Retinyl ester hydrotytic activity associated with human intestinal brusti border membranes. Am. J. Chin. Nutr., v. 60, p. 111-116, 1994.

RININGER, J. A, GOLDSWORTHY, T. L., BABISH, J. G. Time course comparison of cell-cycle protein expression fotlowing partial hepatectomy and WY14,643-induced hepatic œell proliferation in F-344 rats. Carcinogenesis, v. 18, p. 935-941, 1997.

RIZJ, M. B. S. L., DAGLI, M. L. Z, JORDÃO JR, A. A. PENTEADO, M. V. C., MORENO, F. S. B-Carotene inhibils persistent and stimulates remodeling $\gamma \mathrm{GT}$-pasitive preneoplastic lesions during early promotion of hepatocarcinogenesis. Intemat J. Vit Nut. Res., v. 67, p. 415-422, 1997.

ROBERTS, E. S., VAZ, A. D. N., COON, M. J. Role of isozymes of rabbil microsomal cytochrome P450 in the metabolism of retinoic acid, retinol, and rebinal. Mol. Pharmacol., v. 41, p. 427-433, 1992.

ROBERTS, J. M. Turning DNA replicationon and off. Curr. Op. Cell Biol, v. 5, p. 201-206, 1993.

ROCK, C. L., SWENDSEID, M. E. Plasma $\beta$-carotene response in humans after meals supplemented with dietary pectin. Am. J. Clin. Nutr., v. 55, p. 96-99, 1992.

ROGERS, A. E., ZEISEL, S. H., GROOPMAN, J. Diet and carcinogenesis. Cancinogenesis, v. 14, p. 2205-2217, 1993.

RONNE, H., OCKLIND, C., WIMAN, K., RASK, L, OBRINK, B., PETERSON, P. A. Ligant-dependent regulation of intracellular protein transport effect of vitamin A on the secretion of the retinot-binding protein. J. Cell Biol., v. 96, p. $907-910,1983$.

ROOMI, M. W., KO, R. H., SARMA, D. S. R, FARBER, E. A common biocthemical paltem in preneoplastic hepalocyte nodules generated in four different models in the rat. Cancer Res., v. 45, p. 564571, 1985. 
ROSS, A. C. Vitamina A status: relationship to immunity and the antibody responses. Proc. Soc. Exp. Biol. Med, v. 200, p. 303-320, 1992.

ROSS, A. C. Cellular metabolism and activation of retinoids: roles of cellular reinoid-binding proteins. FASEB J., v. 7, p. 317-327, 1993.

ROSS, A. C., STEPHENSEN, C. B. Vitamin A and retinoids in anliviral responses. FASEB J, v. 10, p. 979-985, 1996.

ROSS, A C., TERNUS, M. E. Vitamina A as a hormone: Recent advances in understanding the actions of retinol, relinoic acid, and beta-carotene. J. Am. Diet Assoc., v. 93, p. 1285-1290, 1993.

ROTSTEIN, J., SARMA, D. S. R., FARBER, E. Sequential alterations in growth control and cell dynamics of rat hepatcyles in early precancerous steps in hepatocarcinogenesis. Cancer Res., v. 46, p. 2377-2385, 1986.

ROULEAU, 3., MACLEOD, R., SZYF, M. Regulation of the DNA methylttansferase by the Ras-Ap-1 signaling pattiway. J. Biol. Chem., v. 270, p. 1595-1601, 1995.

ROUS, P., KIDD, J. G. Conditional neoplasms and subthreshold neoplastic states. A study of tar tumors in rabbits. J. Exp. Med, v. 73, p. 365-376, 1941.

ROUSSEAU, E. J., DAVISON, A. J., DUNN, B. P. Protection by B-carotene and related compounds against oxygen-mediated cytotoxicity and genoloxicity: implications for carcinogenesis and anlicarcinogenesis. Free Rad. Biol. Med., v. 13, p. 407-433, 1992.

RUBERTE, E., DOLE், P., KRUST, A, ZELENT, A, MORRIS-KAY, G., CHAMBON, P. Specific spatial and temporal distribution of retinoic acid receptor gamma transcripts during mous embriogenesis. Development v. 108, p. 213-222, 1990.

RUNDHAUG, J. E., PUNG, A, READ, C. M., BERTRAM, J. S. Uptake and metabolism of $\beta$-carotene and retinal by C3H/10T1/2 cells. Carcinogenesis, v. 9 , p. 1541-1545, 1988.

RUSHMORE, T. H., FARBER, E, GHOSHAL, A. K., PARODI, S., PALA, M., TANINGHER, M. A choline devoid diel, carcinogenic in the rat, induces DNA damage and repair. Carcinogenesis, v. 7, p. 1677-1680, 1986.

RUTENBURG, A. M., KIM, H., FISCHEIN, J. W., HANKER, J. S., WASSERKRUG, H. L, SELIGMAN, A. M. Histochernical and ultastructural demonstration of gamma-glutamyl transpeptidase activity. J. Histochem. Cytochem., v. 17, p. 517-526, 1969.

SADEK, I. A., HAYAT, L G. Initiation and post-iniliation chemopreventive effects of beta-carotene in toad liver carcinogenesis. Histol. Histopathol., v. 11, p. 357-360, 1996.

SAFFIOTTI, U., MONTESANO, R., SELAKUMA, A. R, BORK, S. A. Experimental cancer of the lung. Cancer, v. 20, 857-864, 1967.

SAGER, R. Tumor suppressor genes: the puzzle and the promise. Science, v. 246, p. 1406-1412, 1989.

SALBERT, G., FANJUL, A, PIEDRAFITA, F. J., LU, X P., KIM, S. -J., TRAN, P., PFAHL, M. Retinoic acid receptors and reinoid $X$ receptor- $\alpha$ down-regulale the transforming growth factor- $\beta 1$ promoter by antagonizing AP-1 activity. Mol. Endocrinol, v. 7, p. 1347-1356, 1993. 
SALVADORI, D. M. F., RIBEIRO, L. R, OLIVEIRA, M. D. M., PEREIRA, C. A. B., BEÇAK, W. Beta-carolene as a modulator of chromosomal aberrations induced in mouse bone marrow cells. Env. Mol. Mut, v. 20, p. 206210, 1992

SAMBROOK, J., FRITSCH, E. F., MANIATIS, T. Molecular Cloning - A Laboratory Manual. Cold Spring Harbor Laboratory Press, 2nd. ed., New York, 1989.

SAMPAIO, A. R. D. Metilaçāo do DNA em ralos Wistar tratados com $\beta$-caroteno ou vitamina A e submetidos a modelo de hepatocarcinogênese. São Paulo, 120 p. [Dissertação de Mesjado - Faculdade de Ciências Farmacêuticas, Universidade de Sāo Paulo], 1998.

SANTAMARIA, L., BIANCHI, A, ARNABOLDI, A, ANDREONI, L. BERMOND, P. Dietary carotencids block photocarcinogenic enhancement by benzo(a)pireno and inhibits its carcinogenesis in the dark. Experientia, v. 39, p. 1043-1045, 1983.

SANTAMARIA, L., BIANCHI, A, RAVETTO, C., ARNABOLDI, A, SANTAGATI, G., ANDREONI, L Prevention of gastric cancer induced by $N^{\prime}$-metil- $N^{\prime \prime}$-nito- $N$-nitrosoguanidine in rats fed supplemental carotenoids. $J$. Nut. Growth Cancer, v. 4, p. 175-181, 1987.

SANTOS, M. S., MEYDANI, S. N., LEKA, L., WU, D., FOTOUHI, N., MEYDANI, M., HENNEKENS, C. H., GAZIANO, J. M. Natural killer cell activity in elderty men is enhanced by $\beta$-carotene supplementation. Am. J. Clin. Nutr., v. 64, p. 772-777, 1996.

SARGENT, L., DRAGAN, Y, XU, Y. H., SATILER, G., WILEY, J., PITOT, H. C. Karyotypic changes in a multistage model of chemical hepatocarcinogenesis in the rat Cancer Res., v. 56, 0. 2985-2991, 1996.

SARKAR, A, MUKHERJEE, 8., CHATTERJEE, M. Inhibitory effect of $\beta$-carotere on 2-acetylaminofluorene induced hepatocarcinogenesis in rat reflection in hepatic dnug metabolism. Carcinogenesis, v. 15, p. $1055-$ $1060,1994$.

SARKAR, A, BISHAYEE, A, CHATTERJEE, M. Belacarotene prevents lipid peroxidation and red blood œell membrane prolein damage in experimental hepatocarcinogenesis. Cancer Biochem. Biophys., v. 15, p. 111-125, 1995 .

SARKAR, A, MUKHERJEE, B., CHATTERJEE, M. Inhibition of 3'-methyl-4-dimethylaminoazobenzene-induced hopatocarcinogêresis in rat by diekary $\beta$-carotene changes in hepatic anti-oxidant defense enzyne levels. Int J. Cancer, v. 61, p. 799-805, 1995b.

SARKAR, A, BASAK, R., BISHAYEE, A, BASAK, J., CHATTERJEE, M. Betacarotene inhibits rat liver chromosomal aberrations and DNA chain break after a singie injection of diethylnitrosamine. Br. J. Cancer, v. 76, p. $855-861,1997$.

SASAKI, T., YOSHIDA, T. Experimentelle Ezeugung des Lebercarcinoms durch Fütterung mit o-Amidoazotoluol. Virchows Arch. Pathol. Anat, v. 295, p. 175-200, 1935.

SCHERER, E. Relationship among histochemically distinguishable eariy lesions in mullistep-multistage hepatocarcinogenesis. Arch. Toxicol, v. 10, p. 81-94, 1987.

SCHMĀHL, D., PREUSSMANN, R., HAMPERL, H. Leberkrebserzeugende Winkung von Diähylnitrosamin nach oraler Gabe bei Ratten. Natuswissenschaften, v. 47, p. 89, 1960. 
SCHMANDT, R., MLLS, G. B. Genomic components of carcinogenesis. Clin. Chem., v. 39, p. 2375-2385, 1993.

SCHMITZ, H. H., POOR, C. L., WELLMAN, R. B., ERDMAN, J. W. Conœentations of selected carolenoids and vitamin A in human liver, kidney and lung tissue. J. Nutr., v. 121, p. 1613-1621, 1991.

SCHULTE-HERMANN, R. Tumor promation in the liver. Arch, Toxicol, v. 57, p. 147-158, 1985.

SCHULTE-HERRMANN, R, TIMMERMANN-TROSIENER, I., BARTHEL, G., BURSCH, W. DNA synthesis, apoptosis, and phenotipic expression as determinants of growth of altered foci in rat Fver during ohenobarbital promotion. Cancer Res., v. 50, p. 5127-5135, 1990.

SCHULZE-OSTHOFF, K., LOS, M., BAEUERLE, P. A. Redox signalling by transcription factors NF-xB and AP-1 in the immune system. Biochem. Pharmacol, v. 50, p. 736-741, 1995.

SCHULZE-OSTHOFF, K., BAUER, M. K. A, VOGT, M. WESSELBORG, S. Oxidalive stress and signal transduction. Intemat J. Vit Nurr. Res., v. 67, p. 336-342, 1997

SCHWARTZ, J. L. In vitro biological methods for determination of carotenoid activity. Methods in Enzymol, v. 214, p. 226-256, 1994.

SCHWARTZ, J., SHKLAR, G. Regression of experimental oral carcinomas by local injection of $\beta$-carotene and canthaxanthin. Nutr. Cancer, v. 11, p. 35-40, 1988.

SCHWARTZ, J., SHKLAR, G. The selective cytotoxic effect of carotenoids and $\alpha$-tocopherol on human cancer cell lines in vitro. J. Oral Maxillofac. Surg., v. 50, p. 367-373, 1992.

SCHWARTZ, J., SUDA, D., LIGHT, D. Beta-carotene is associated with the regression of hamster buccal pouch cancinoma and the induction of turnor necrosis factor in macrophages. Biochem. Biophys. Res. Commun., v. 136, p. 1130-1135, 1986 .

SCHWARTZ, J., SHKLAR, G, REID, S., TRICKLER, D. Prevention of experimental oral cancer by extacts of Spirulina-Dunaliella algee. Nutr. Cancer, v. 11, p. 127-34, 1988.

SCHWARTZ, J. L., SINGH, R. P., TEICHER, B., WRIGHT, \&. E, TRITES, D. H., SHKLAR, G. Induction of a 70 $\mathrm{KD}$ protein associated with the selective citotoxicily of beta-carotene in human epidemal carcinoma. Biochem. Biophys. Res. Commun., v. 169, p. 941-946, 1990.

SCHWARTZ, J. L., FLYNN, E., TRICKLER, D., SHKLAR, G. Directed lysis of experimental cancer by $\beta$-carolene in liposomes. Nutr. Cancer, v. 16, p. 107-124, 1991.

SCHWART, J., TANAKA, J., KHANDEKAR, V., HERMAN, T. S., TEICHER, B. A. Bela-carolene andior vitamin $\mathrm{E}$ as modulalor of alkylating agents in SCC-25 human squamous carcinoma cells. Cancer Chemother. Pharmacol. v. 29, p. 207-213, 1992.

SCHWARTZ, J. L., ANTONIADES, D. Z., ZHAO, S. Molecular and biochemical reprogramming of oncogenesis through the aclivity of prooxidants and antioxidants. Ann. NY Acad. Sci, v. 686, p. 262-279, 1993

SCOT, R. E. Differentiation, differentiationdgene therapy and cancer. Pharmacol. Ther., v. 73, p. 51-65, 1997.

SCRABLE, H J., SAPIENZA, C., CAVENEE, W. K. Genetic and epigenetic losses of heterozygosity in cancer predisposition and progression. Adv. Cancer Re., v. 54, p. 25-62, 1990. 
SEIFTER, E., RETTURA, G., PADAWER, J., STRATTFORD, F., GOODWIN, P. LEVINSON, S. M. Regression of C3HBA mouse tumor due to $\mathrm{x}$-ray therapy combined with supplementary beta-carotene or vitamin A. $J$. Natt. Cancer inst, v. 68, 0. 409-417, 1981.

SEIFTER, E., RETTURA, G., PADAWER, J., LEVINSON, S. M. Moloney murine sarcoma virus tumors in CBAIJ mice: Chemopreventive and chemotherapeutic actions of supplemental beta-carotene. J. Natt Cancer inst, v. 71, p. $835-840,1982$

SEIFTER, E., RETTURA, G., LEVINSON, S. M. Supplemental beta-carotene (BC): Prophylactic action against 7,12 dimethylbenz(a)-anthracene (DMBA) carcinogenesis. Fed. Proc., v. 43, p. 662, 1984.

SEIL, S. Distribution of alphafeloprotein and albumin containing cells in the livers of Fischer rats fed four cycles of N-2-fluorenylacetamide. Cancer Res., v. 38, p. 3107-3113, 1978.

SEL, S. Is there a liver stem cell? Cancer Res., v. 50, p. 3811-3815, 1990.

SELL, S., DUNSFORD, H. A. Evidence for the stem cell origin of hepatocellular carcinoma and cholangiocarcinoma. Amer. J. Pathol. v. 134, p. 1347-1363, 1989.

SELL, S., LEFFERT, H. An evaluation of cellular lineages in the pathogenesis of experimental hepatocellular carcinoma. Hepotology, v. 2, p. 67-78, 1982.

SELL, S., PIERCE, G. B. Maturation arrest of slem cell differentiation is a common pathway for the cellular origin of teratocarcinomas and epitelial cancers. Lab. Invest, v. 70, p. 6-22, 1994.

SELLS, M. A, KAYTAL, S. R, SELL, S., SHINOZUKA, H., LOMBARDI, B. Induction of foci of altered rglutamylt anspeptidase-positive hepatocytes in carcinogen-treated rats fed a choline-deficient diet Br. J. Cancer, v. 40, p. 274-283, 1979.

SEMPLE-ROBERTS, E, HAYES, M. A, ARMSTRONG, D., BECKER, R. A., RACZ, W. J., FARBER, E. Alternative methods of selecting rat hepalocellular nodules resistant to 2-acelylaminofiuorene. Int $\mathrm{J}$. Cancer, v. 40, p. 643-645, 1987.

SEN, C. K., PARCKER, L. Anlioxidant and redox regulation of gene transcription. FASEB J., v. 10, p. 709-720, 1996.

SHAMBERGER, R. J. Inhibitory effect of vitamin A on carcinogenesis. J. Nat. Cancer Inst, v. 47, p. 667-672, 1971.

SHAPIRO, S. S., MOTT, D. J., MACHLIN, L. J. Kinetic characteristics of beta-carotene uptake and depletion in rat lissue. J. Nutr., v. 114, p. 1924-1933, 1984.

SHARMA, R. V., MATHUR, S. N., DIMITROVSKII, A. A., DAS, R. C., GANGULY, J. Studies on the metabolism of $\beta$-carotene and apo- $\beta$-carotenoids in rats and chickens. Biochim. Biophys. Acta., v. 486, p. 183-194, 1977.

SHARMA, S., STUTZMAN, J. D., KELOFF, G. J., STEELE, V. E. Screening of potential chemopreventive agents using biochemical markers of carcinogenesis. Cancer Res., v. 54, p. 5848-5855, 1994.

SHAW, J. The Cure of Cancer. and How Surgery Blocks the Way. London: Tumey, 1907. 
SHEKELLE, R B., LIU, S., RAYNOR JR., W. J., LEPPER, M., MALIZA, C., ROSSOF, A. H. Dietary vitamin A and risk of cancer in the Western Electric Study. Lancet, v. 2, p. 1185-1189, 1981.

SHKLAR, G., SCHWARTZ, J. L. Tumor necrosis factor in experimental cancer: regression sith alpha tocopherol, bela-carotene, and algae extract Eur. J. Cancer Oncol, v. 24, p. 839-850, 1988.

SHKLAR, G., SCHWARTZ, J. Oral cancer inhibition by micronutrients. The expenimental basis for ctinical trials. Oral Oncol. Eur. J. Cancer, v. 29B, p. 9-16, 1993.

SHKLAR, G., SCHWARTZ, J. A common pathway for the destruction of cancer œells: experimental evidence and clinical implications. Int J. Oncol, v. 4, p. 215-224, 1994.

SHKLAR, G., SCHWARTZ, J., TRICKLER, D., REID, S. Regression of experimental cancer by oral administration of combined $\alpha$-tocopherol and $\beta$-carotene. Nutr. Cancer, v. 12, p. 321-325, 1989.

SHUBIK, $P$. The growth potentialities of induced skin tumors in mice. The effects of different methods of chemical carcinogenesis. Cancer Res., v. 10, p. 713-717, 1950.

SIES, H., STAHL, W. Vitamins $E$ and $C, \beta$-carotene, and other carotenoids as antioxidants. Am. J. Clin. Nutr, v. 62, p. 1315S-1321S, 1995.

SIES, H., STAHL, W. Carotenoids and intercellular communication via gap junctions. Intemat J. Vitam. Nutr. Res., v. 67, p. 364367, 1997.

SIGAL, S. H., BRILL, S., FIORINO, A. S., REID, L. M. The liver as a stem cell and lineage system. Am. J. Physiol, v. 263, p. G139-G148, 1992.

SILVEIRA, E. R. Efeilto das administraçóes de vitamina A e dos àcidos retinóicos todo-trans e 9-cis em ratos Wistar na etapa de progressão de modelo de hepatocarcinogênese. Săo Paulo, 97 p. Dissertação de Mestrado - Faculdade de Ciências Farmacêuticas, Universidade de São Paulo], 1998.

SILVEIRA, E. R, MORENO, F. S. Naturad retinoids and $\beta$-carotene: from food to their actions on gene expression. J. Nutr. Biochem. v. 9, p. 446-456, 1998.

SKLAN, D. Carolene deavage activity in the corpus luteum of catte. Int J. Vitamin. Nutr. Res., v. 53, p. 23-26, 1983.

SLAGA, T. J. Inhibition of skin turnor initiation, promotion, and progression by anlioxidants and related compounds. Crit Rev. Food Sci. Nutr., v. 35, 0. 51-57, 1995.

SMELAND, S., BJERKNES, T, MALABA, L., ESKILD, W., NORUM, K. R, BLOMHOFF, R. Tissue distribution of the receptor for plasma relinol-binding protein. Biochem. J., v. 305, p. 419-424, 1995.

SMITH, P. G., JICK, H. Cancers among users of preparations containing vitamin $A:$ a case-control investigation.Cancer, v. 42, p. 808-811, 1978.

SMITH, S. S. DNA methylation in eukaryotic chromosome stability. Mol. Carcinog. v. 4, p. 91-92, 1991.

SMUCKLER, E. A. Chemicals, cancer and cancer biology. West J. Med., v. 139, p. 55-74, 1983. 
SOLOMONS, N. W. BULUX, J. Effects of nutritional slatus on carotene uptake and bioconversion. Ann. N. Y. Acad. Sci, v. 691, 0. 96-109, 1993.

SOLT, D. T., FARBER, E. New principle for the analysis of chemical carcinogenesis. Nature, v. 263, p. 702-703, 1976.

SOLT, D. 8., CAYAMA, E., TSUDA, H., ENOMOTO, K., LEE, G., FARBER, E. PTomotion of liver cancer development by brief exposure to dietary 2-acetylaminofluorene plus partial hepatectomy or carbon tetachloride. Cancer Res., v. 43, p. 178-181, 1983.

SOM, S., CHATTERJEE, M., BANNERJEE, M. R. Beta-carotene inhibition of 7,12-dimethylbenz(a)anthraceneinduced transformation of murine mammary cells in vitro. Carcinogenesis, v. 5, p. 937-940, 1984.

SOMA, M. R., CORSINI, A, PAOLETTI, R Cholesterol and mevalonic acid modulation in cell metabolism and multiplication. Toxicol. Lett, v. 64/65, p. 1-15, 1992.

SOPRANO, D. R, SOPRANO, K. J., GOODMAN, D. S. Retinol-binding protein messenger RNA levels in the liver and in extrahepatic tissues of the rat J. Lipid Res., v. 27, p. 166-171, 1986.

SORENSON, C. M. BARRY, M. A, EASTMAN, A. Analysis of events associated with cell cycte arrest at $G_{2}$ phase and œell death induced by cisplatin. J. Nat. Cancer inst, v. 82, p. 749-755, 1990.

SOUTHERN, E Delection of specific sequences among DNA fragmenis separated by gel electrophoresis. J. Mol. Biol, v. 98, p. 503-517, 1975.

SPORN, M. B., DUNLOP, N. M., NEWTON, D. L., SMITH, J. M. Prevention of chemical carcinogenesis by vitamin $A$ and its synthelic analogs (retinoids). Fed. Proc., v. 35, p. 1332-1338, 1976.

SPORN, M. B., ROBERTS, A. B., GOODMAN, D. S., eds. The Retinoids: biology, chemistry, and medicine, 2nd ed. Raven Press, New York, p. 1-679, 1994.

SQUIRE, R. A., LEVTT, M. H. Report of a workshop on classification of spectic hepatocelular lesions in rats. Cancer Res., v. 35, p. 3214-3223, 1975.

STÄHELIN, H. B., GEY, X. F., EICHHOLZER, M., LÜDIN, E. $\beta$-Carotene and cancer prevention: the Basel study, Am. J. Clin. Nuts., v. 53, p. 265s-269S, 1991.

STAHL, W., SIEHS, H. Uptake of lycopene and its geometical isomers is greater from heat-processed than from unprocessed tomato juice in humans. J. Nut, v. 122, p. 2161-2166, 1992.

STAHL, W., SCHWARZ, W., SUNDQUIST, A. R., SIES, H. Cis-trans isomers of fycopene and $\beta$-carotene in human serum and tissues. Arch. Biochem. Biophys., v. 294, p. 173-177, 1992.

STAHL, W., SCHWARTZ, W., VON LAAR, J., SIES, H. Al-trans $\beta$-carotere preferentialy accumulates in human chylomicrons and very low density lipoproteins compared with the 9-cis geometrical isomer. J. Nutr., v. 125, p. 2128-2133, 1995.

STAHL, W., NICOLAI, S., BRIVIBA, K., HANUSCH, M., BROSZEIT, G., PETERS, M., MARTIN, H.-D., SIES, H. Biological activitios of natural and synthetic carotenoids: induction of gap junctional communication and singlel oxygen quenching. Carcinogenesis, v. 18, p. 89-92, 1997. 
STAחAND, B. E. Nutrition and cancer. Clin. Chem., v. 38, p. 1587-1594, 1992.

STARK, A. A, RUSSELL, J. J, LANGENBACH, R, PAGANO, D. A, ZEIGER, E., HUBERMAN, E. Localization of oxidative damage by a glutathione-gamma-glutamyl transpeptidase system in preneoplastic lesions in sections of livers from carcinogen-treated rats. Carcinogenesis, v. 15, p. 343-348, 1994.

STEER, C. J. Liver regeneration. FASEB J., v. 9, p. 1396-1400, 1995

STEINE, H. H., BAKER, R. S. U. Effects of $\beta$-carotene on chemically-induced skin tumors in HRASSkh hairless mice. Cancer Lett, v. 51, p. 163-168, 1990.

STICH, H. F., DUNN, B. P. Relationship betwen cellular levels of $\beta$-carotene and sensitivity to genotoxic agents. Int J. Cancer, v. 38, p. $713-717,1986$.

STICH, H. F. ROSIN, M. P. Micronudei in exfoliated human cells as a tool for studies in cancer risk and cancer intervention. Cancer Lett, v. 22, p. 241-253, 1984.

STICH, H. F., ROSIN, M. P., VALLEJERA, M. O. Reduction with vitamin A and beta-carotene administration of proportion of micronucleated buccal mucosal cells in asian betel nut and tobacco chewers. Lancet, v. i, p. 12041206, 1984 .

STCH, H. F., STICH, W., ROSIN, M. P., VALLEJERA, M. O. Use of the micronucteus test to monitor the effect of

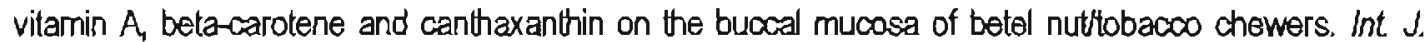
Cancer, v. 34, p. $745-750,1984$ b.

STICH, H. F., HORNBY, A. P., MATHEW, B., SANKARANARAYANAN, R., KRISHMAN NAIR, M. Response of oral leukoplakias to the administration of vitamin A. Cancer Lett, v. 40, p. 93-101, 1988a.

STICH, H. F., ROSIN, M. P., HORNBY, A P., MATHEW, B., SANKARANARAYANAN, R., KRISHMAN NAIR, M. K. Remisssion of oral leukoplakias and micronuclei in tobaccolbetel quid chewers treated with betacarotene and with beta-carotene plus vitamin A. Int J. Cancer, v. 42, p. 195-199, 1988b.

STICH, H. F., MATHEW, B., SANKARANARAYANAN, R., KRISHMAN NAIR, M. Remission of precancorous lesions of the cral cavity of tobacos chewers and maintenance of the protective effect of belacarolene or vitamin A. Am. J. Clín. Nutr., v. 53, p. 298S-304S, 1991.

STOCKS, P. Cancer incidence in North Wales and Liverpool region in relation to habits and environtrment British Empire Cancer Campaign 35th Ann. Report, v. 2, p. 1-127, 1933.

STONER, G. D., MORSE, M. A, KELOFF, G. J. Perspectives in cancer chemoprevention. Environ. Health Perspect, v. 105, p. 945-954, 1997.

SUDA, D., SCHWARTZ, J., SKHLAR, G. Inhibition of experimental oral carcinogenesis by topical beta-carotene. Carcinogenesis, v. 7, p. 711-715, 1986.

SUGITANI, S., SAKAMOTO, M., ICHIDA, T., GENDA, T., ASAKURA, H., HIROHASH, S. Hyperplastic foci reflect the risc of multicentric development of human hepatocalular carcinoma J. Hepatol, v. 28, p. 1045-1053, 1998. 
SUN, $X_{1}$ SHIMIZU, K., YAMAMOTO, K. -I. Identification of a novel $p 53$ promoter element involved in genotoxic stress-inducible p53 gene expression. Mol. Cell. Biol, v. 15, p. 4489-4496, 1995.

SWISSHELM, K., RYAN, K., LEE, X, TŚOU, H. C., PEACOCKE, M., SAGER, R. Down-regulation of rebinoic acid receptor $\beta$ in mammary carcinoma $\infty$ il lines and its up-regulation in senescing normal mammary epithelial cells. Cell Growth \& Differ, v. 5, p. 133-141, 1994

SZYF, M., MEISELS, E., RAZIN, A. Biological role of DNA methylation: sequence-specific single-strand breaks associated with hypomethylation of GATC sites in Escherichia coli DNA. J. Bacteriol, v. 168, p. 1487-1490, 1986.

TAMAI, H., MORINOBU, T., MURATA, T., MANAGO, M., MINO, M. 9-cis $\beta$-Carotene in human plasma and blood colls after ingestion of $\beta$-carotene. Lipids, v. 30, p. 493-498, 1995.

TANAKA, T., MAKITA, H., OHNISHI, M, HIROSE, Y., WANG, A, MORI, H., SATOH, K., HARA, A, OGAWA, H. Chemoprevention of 4nitroquinoline 1-oxide induced oral carcinogenesis by dielary curcumin and hesperidin: comparison with the protective effect of $\beta$-carotene. Cancer Res., v. 54, p. 4653-4659, 1994.

TANG, G. -W., WANG, X.-D., RUSSELL, R. M., KRINSKY, N. I. Characterization of $\beta$-apo-13-carotenone and $\beta$-apo-14'-carotenal as enzymatic products of the excentric cleavage of $\beta$-carotene. Biochemistry, v. 30, p. 9829-9834, 1991.

TANNENBAUM, A. Relationship of body weight to cancer incidence. Archs. Path., v. 30, p. 509-517, 1940.

TANNENBAUM, A. The genesis and growth of tumors. If. Effects of caloric restrition per se. Cancer Res., v. 2, p. $460-467,1942 \mathrm{a}$.

TANNENBAUM, A. The genesis and growth of tumors. III. Effects of a high-fat diet. Cancer Res., v. 2, p. 468-474, $1942 b$.

TARSEITI, F., LENZI, R., SALVE, R, SCHULER, E., RIJHSINGHANI, K., LENZIN, R., TAVOLINI, N. LiNer carcinogenesis associated with feeding of ethionine in a choline-free diet evidence against a role of oval cells in the emergence of hepatocellular carcinoma. Hepatology, v. 18, p. 596-603, 1993.

TATEMATSU, M., NAGAMINE, Y., FARBER, E. Redifferentiation as a basis for remodeling of carcinogeninduced hepatocyte nodules to normal appearing liver. Cancer Res., v. 43, p. 5049-5058, 1983.

TEE, E. -S, LIM, C. -L, CHONG, Y. -H, KHOR, S. -C. A study of the biological utilization of carotenoids of carrot and swamp cabbage in rats. Food Chem., v. 56, p. 21-32, 1996.

TEE, L B. G., KIRILAK, Y., HUANG, W-. H., SMTTH, P. G. J., MORGAN, R. H., YEOH, G. C. T. Dual phenotypic expression of hepatocytes and bile ductular markers in developing and preneoplastic ral fiver. Carcinogenesis, v. 17, p. 251-259, 1996.

TEMPLE, N. J., BASU, T. K. Proteclive effect of $\beta$-carotene against colon tumors in mice. J. Natt. Cancer Inst, v. 78, p. 1211-1214, 1987.

THANE, C., REDDY, S. Processing of fruit and vegetables: effect on carotenoids. Nut. Food Sci, v. 2, p. 58-65, 1997. 
THE ALPHA TOCOPHEROL, BETA-CAROTENE CANCER PREVENTION STUDY GROUP. The effecls of vilamin $E$ and bela-carotene on the incidence of lung cancer and other cancers in male smokers. N. Engl. $J$. Med. v. 330, p. 1029-1035, 1994.

TOBA, T., SHIDOJI, Y., FUJII, J., MORIWAKI, H., MUTO, Y, SUZUKI, T., OHISHI, N., YAGI, K. Growth suppresion and induction of heat-schock protein-70 by 9 -cis beta-carotene in cervical dysplasiz-derived cells. Life Sci, v. 61, p. 839-845, 1997.

TOMATIS, L. Cell proliferation and carcinogenesis a brief history and current view based on an IARC workshop report International Agency for Resaarch on Cancer. Environ. Health Perspect, v. 101, p. 149-151, 1993.

TOMITA, Y, HIMENO, K., NOMOTO, K., ENDO, H., HIROHATA, T. Augmentation of tumor immunity against syngenic tumors in mice by ß-carotene. J. Nat. Cancer. Inst, v. 78, p. 679-680, 1987.

TRABER, M. G., DIAMOND, S. R., LANE, J. C., BRODY, R l., KAYDEN, H. J. $\beta$-Carotene transport in human lipoproteins. Comparisons with a-tocopherol. Lipids, v. 29, p. 665-669, 1994.

TRAVIS, C. C., BELEFANT, H. Promotion as a factor in carcinogenesis. Toxicol. Lett, v. 60, p. 1-9, 1992.

TRIGUEIRO, I. N. S., PENTEADO, M. D. V. C. Teores de alfa e beta-caroteno e alividades pró-vitamínica A de òleos de dendê brasileiras. Rev. Farm. Bioquím. Univ. São Paulo, v. 28, p. 61-74, 1992.

TSUDA, H., UEHARA, N., IWAHORI, Y, ASAMOTO, M., IIGO, M., NAGAO, M., MATSUMOTO, K., ITO, M., HIRONO, 1. Chemopreventive effects of beta-carotene, alpha-locopherol and five naturally ocourring antioxidants on initiation of hepatocarcinogenesis by 2-arnino-3-methylimidazo[4,5-f]quinoline in the rat. Jpn. J. Cancer Res., v. 85, p. 12141219, 1994.

TSUJII, M., DUBOIS, R. N. Alterations in ceilular adhesion and apoptosis in epithelial cells overexpressing prostaglandin endoperoxide synthase 2 Cell, v. 83, p. 493-501, 1995.

TZEN, C.-Y., ESTERVG, D. N., MINOO, P., FILIPAK, M., MAERCKLEIN, P. B., HOERL, B. J., SCOTT, R. E. Differentiation, cencer, and anticancer activity. Biochem. Cell. Biol, v. 66, p. 479-489, 1988.

UEDA, N., SHAH, S. Apoptosis. J. Lab. Clin. Med, v. 124, p. 169-177, 1994.

UEHARA, N., IWAHORI, Y., ASAMOTO, M., BABA-TORIYAMA, $H_{.}$, IIGO, M., OCHIA, M., NAGAO, M., NAKAYAMA, M. DEGAWA, M., MATSUMOTO, K., HIRONO, I., BEPPU, H., FUJITA, K., TSUDA, $H$. Decreased levels of 2-amino-methylimidazo[4,5-fifquinoline-DNAradducts in rats teated with bela carotene, alpha-tooopherol and freeze-dried aloe. Jpn. J. Cancer Res., v. 87, p. 342-348, 1996.

ULRICH, A, SCHLESSINGER, J. Signal transduction by receptors with tyrosine kinase activity. Cell, v. 61, p. $203-212,1990$.

URIEl, J. Cancer, retrodifferentiation, and the myth of Faust Cancer Res., v. 36, p. 4269-4275, 1976.

USHIJIMA, T., MORIMURA, K., HOSOYA, Y., OKONOG, H., TATEMATSU, M., SUGIMURA, T., NAGAO, M. Establishment of methylation-sensitive-representational difference analysis and isolation of hypo- and hypermethylated genomic fragments in mouse liver tumors. Proc. Natt. Acad Sci. USA, v. 94, p. 2284-2289 1997. 
VAN DEN HEUVEL, S., HARLOW, E. Distinct roles for cyclin-dependent kinases in cell cycle control. Science, v. 262, p. 2050-2054, 1993.

VAN LIESHOIJT, E M. M., FETERS, W. H. M., JANSEN, J. B. M. J. Effect of oltipraz, $\alpha$-tocophero, $\beta$-carotene and phenethylisothiocyanate on rat oesophageal, gastric, colonic and hepatic glutathione, giutathione $S$ transterase and peroxidase. Carcinogenesis, v. 17, p. 1439-1445, 1996.

VAN POPPEL, G., GODBOHM, R. A. Epidemiological evidence for $\beta$-carotene and cancer prevention, Am. J. Clin. Nutr., v. 62, p. 1393s-1402S, 1995.

VAN POPPEL, G., KOK, F. J., HERMUS, R. J. Betacarolene supplementation in smokers reduces the frequency of micronuclei in sputum. Br. J. Cancer, v. 66, p. 1164-1168, 1992.

VAN VLIET, T. Absorption of $\beta$-carotene and other carotenoids in hurmans and animal models. Eur. J. Clin. Nutr., v. 50, p. $\$ 32.537,1996$.

VAN VLIET, $T$, VAN VLISSINGEN, M. F., VAN SCHAIK, F., VAN DEN BERG, H. Beta-carotene absorption and deavage in rats is affected by the vilamin A concentration of the diet J. Nutr., v. 126, p. 499-508, 1996.

VARMUS, H. Ar historical overview of onoogenes. In: Oncogenes and the Molecular Origins of Cancer, R. A. Weinberg, ed., New York, Cold Spring Harbor Laboratory Press, p. 3-44, 1989.

VENITT, S. Mechanisms of carcinogenesis and individual susceplibility to cancer. Clin. Chem., v. 40, p. 14211425,1994 .

$X U, X$-C., RO, J. Y., LEE, J. S., SHIN, D. M, HONG, W. K., LOTAN, R. Differential expression of nuclear retinoid receptors in normal, premalignant, and malignant head and neck tissues. Cancer Res., v. 54, p. 3580-3587, 1994.

$X U, X$-C., SNEIGE, N., LIU, X, NANDAGIRI, R., LEE, J. J., LUKMANJI, F., HORTOBAGYI, G., LIPPMAN, S. M., DHINGRA, K., LOTAN, $R$. Progressive decrease in nudear retinoic acid receptor $\beta$ messenger RNA level during breast carcinogenesis. Cancer Res., v. 57, p. 4992-4996, 1997.

WALD, G. The visual furctions of the vitamins A. Vitam. \& Horm., v. 18, p. 417-430, 1960.

WALKER, M. R., RAPLEY, R. Oncogenes and the molecular basis of cancer. Route Maps In Gene Technology, Oxford, Balckweil Scienœ Lid., p. 250-253, 1997.

WAN, Y. J., WANG, L., WU, T. C. Expression of retinoic acid receptor genes in developing rat livers and hepatoma cells. Lab. Invest, v. 66, p. 646-651, 1992.

WANG, X -D. Review. absorption and metabolism of $\beta$-carotene. J. Am. Coll. Nutr., v. 13, p. 314-325, 1994.

WANG, X.-D., TANG, G. -W., FOX, J. G., KRINSKY, N. I, RUSSEL, R. M. Enzymatic conversion of $\beta$-carotene into $\beta$-apo-carotenals and retinoids by human, monkey, ferrel, and rat lissues. Arch. Biochem. Biophys, v. 285, p. 8-16, 1991.

WANG, X. -D, KRINSKY, N. L., RUSSELL, R. M. Rebinoic acid regulates retinol melabolism via feedback inhibition of retinol oxidation and stimulation of retinol esterification in ferret liver. J. Nut., v. 123, p. 1277-1285, 1993. 
WANG, X -D., KRINSKY, N. I., BENOTTI, P. N., RUSSELL, R. M. Biosynthesis of 9-cis retinoic acid from 9-cis $\beta$ carotene in human intestinal mucasa in vito. Arch. Biochem. Biophys., v. 313, p. 150-155, 1994.

WANG, W., HIGUCHI, C. M. Induction of NAD(P)H:quinone reductase by vitamins $A, E$ and $C$ in Colo205 colon cancer cells. Cancer Lett, v. 98, 0. 63-69, 1995 [errata em Cancer Lett, v. 101, p. 265), 1996.

WARRELL JR, R. P., DE THE, H., WANG, Z. -Y., DEGOS, L. Acule promyelocytic leukemia. N. Engl. J. Med., v. 329, p. 177-189, 1993.

WASSERMAN, W. W., FAHL, W. E. Functional antioxidant responsive elements. Proc. Natt. Acad. Sci. v. 94, p. 5361-5366, 1997.

WATTENBERG, L. W. Inhibition of neoplasia by minor dietary constituents. Cancer Res, v. 2448s-2453s, 1983.

WATTENBERG, L W. Chemoprevention of cancer. Cancer Res., v. 45, p. 1-8, 1985.

WATTENBERG, L. W. Inhibition of carcinogenesis by minor anutrient constituents of the diet. Proc. Nutr. Soc., v. 49, p. 173-183, 1990.

WATIENBERG, L. W. Inhibition of fumorigenesis in animals. IARC Sci. Publ, v. 139, p. 151-158, 1996.

WATTENBERG, L. W. An overview of chemoprevention: currenl status and future prospects. Proc. Soc. Exp. Biol. Med., v. 216, p. 133-141, 1997.

WEINSTEIN, I. B. The origins of human cancer: molecular mechanisms of carcinogenesis and their implications for cancer prevention and treament Cancer Res., v. 48, p. 4135-4143, 1988.

WEISBURGER, J. H., RAINERI, R. Dietary factors and the etiology of gastric cancer. Cancer Res, v. 35, p. $3469-3474,1975$.

WEITBERG, A. B., WEITZMAN, S. A, CLARK, E. P., STOSSEL, T. P. Effects of anlioxidants on oxidant-induced sister chromatid exchange formation. J. Clin. Invest, v. 75, p. 1835-1841, 1985.

WHITE, W. S., PECK, K. M., BIERER, T. L., GUGGER, E. T., ERDMAN, J. W. Interactions of oral $\beta$-carolene and canthaxanthin in ferrets. J. Not., v. 123, p. 1405-1413, 1993.

WILLAMS, G. M. The pathogenesis of rat liver cancer caused by chemical carcinogens. Biochim. Biophys. Acta, v. 605, p. $167-189,1980$.

WILLIAMS, W. The Natural History of Cancer, with Special Reference to its Causation and Prevention. London: Heinemann, 1908.

WILSON, M. J., SHIVAPURKAR, N., POIRIER, L. A. Hypomethylation of hepatic nuclear DNA in rats fed with a carcinogenic methyl-deficient diet Biochem. J., v. 218, p. 987-990, 1984.

WINGERATH, T., STAHL, W., SIES, H. $\beta$-Cryptoxanthin selectively increases in human chylomicrons upon ingestion of tangerine concentrate rich in $\beta$-cryptoxanthin esters. Arch. Biochem. Biophys, v. 324, p. 385390, 1995.

WISEMAN, R. Several Chirurgicall Treatises. London: Flesher \& Macook. 
WOLBACH, S. B., HOWE, P. R. Tissue changes following deprivation of fat-soluble A-vitamin. J. Exp. Med., v. 42, p. $753-778,1925$.

WOLF, G. The intracellular vitamin A-binding proleins: an overview of their functions. Nut. Rev., v. 49, p. 1-11, 1991.

WOLF, G. The enzymatic cleavage of $\beta$-carotene: still controversial. Nutr. Rev., v. 53, p. 134-137, 1995.

WOLF, G. A history of vitamin A and retinoids. FASEB J., v. 10, p. 1102-1107, 1996.

WORL CANCER RESEARCH FOUNDATIONAMERICAN INSTITUTE FOR CANCER RESEARCH. Introduction. In: Food, Nutition and the Prevention of Cancer. a Global Perspective, p. 13-17, 1997a.

WORLD CANCER RESEARCH FOUNDATIONAAMERICAN INSTITUTE FOR CANCER RESEARCH. Palterns of cancer. In: Food, Nutrition and the Prevention of Cancer. a Gbobal Perspective, p. 35-52, $1997 \mathrm{~b}$.

WORLD CANCER RESEARCH FOUNDATIONIAMERICAN INSTITUTE FOR CANCER RESEARCH. Liver. In: Food, Nutrition and the Prevention of Cancer. a Global Perspective, p. 202-214, 1997c.

WOFLD CANCER RESEARCH FOUNDATIONAMERICAN INSTITUTE FOR CANCER RESEARCH. Prevention and its benefits. In: Food, Nutrition and the Prevention of Cancer, a Global Perspective, p. 538 548,1997 d.

WORLD CANCER RESEARCH FOUNDATIONAMERICAN INSTITUIE FOR CANCER RESEARCH. VitaminS. In: Food, Nutrition and the Prevention of Cancer. a Global Perspective, p. 404416, $1997 \mathrm{e}$.

WOUTERSEN, R A, VAN GARDEREN-HOETMER, A. Inhibition of dietary fat promoled development of (pre)neoplastic lesions in exocrine pancreas of rats and hamsters by supplemental selenium and $\beta$ carotene. Cancer Lett, v. 42, p. 79-85, 1988.

WU, T. -S, MORENO, F. S. Carcinogênese hepática. In: Modelos Experimentais de Pesquisa em Cirurgia e Anestesia. O. CASTRO E SILVA Jr., A BEER Jr., S. ZUCOLOTO, eds. Robe Editorial, cap. 70, p. 698-705, 1998.

WYNDER, E., GORI, G. Contribution of the environment to cancer incidenœ: an epidemiologicat exercise. J. Nat. Cancer inst, v. 58, p. 825-832, 1977.

WYNDER, E. L., SHIGEMATSU, T. Environmental factors of cancer of the colon and rectum. Cancer, v. 20, p. 1520-1561, 1967.

YAMAGIWA, K., ICHIKAWA, K. Experimentelle Studie über die Pathogenese der Epithelialgeschwülste. Mitt Med. Fak. Tokio, v. 15, p. 295, 1915.

YAMAGIWA, K., ICHIKAWA, K. Experimental study of the pathogenesis of carcinoma. J. Cancer Res., v. 3, p. 1$21,1918$.

YOKOTA, J., SUGIMURA, T. Multiple steps in carcinogenesis involving alterations of multiple turnor suppressor genes. FASEB J., v. 7, p. 920-925, 1993.

YOKOYAMA, S., SELLS, M. A, REDDY, T. V., LOMBARDI, B. Hepatocarcinogenesis and promoting action of a choline-devoid diet in the rat Cancer Res., v. 45, 0. 28342842, 1985. 
YONISH-ROUACH, E., RESNITZKY, D., LOTEM, J., SACHS, L., KIMCHI, A., OREN, M. Wild-type p53 induces apoptosis of myeloid leukemic cells that is inhibiled by interleukin-6. Nature, v. 352, p.345-347, 1991.

YOU, C. S., PARKER, R. S., GOODMAN, K. J., SWïANSON, J. E., CORSO, T. N. Evidence of cis-trans isomerization of 9-cis-ß-carotene during absorplion in humans. Am. J. Clin Nutr. v. 64, p. 177-183, 1996.

YOUNGMAN, L. D., CAMPBELL, T. C. Inhibition of aflatoxin B1 - induced gamma glutarnyltranspeptidase positive (GGT +) hepatic preneoplastic foci and turnors by low protein diets: evidence that altered GGT + foci indicake neoplastic potential. Carcinogenesis, v. 13, p. 1607-1613, 1992.

YUSPA, S. H. The pathogenesis of squamous cell cancer: lessons learned from studies of skin carcinogenesis - thirty-third G. H. A. Clowes Memorial Award Lecture. Cancer Res., v. 54, p. 1178-1189, 1994.

ZACARIAS, W. Methylation of cylosine influences the DNA structure. In: DNA methylation: molecular biology and biological significance. J. P. JOST, H. P. SALUZ, eds. Birkhâuser Verlag, Basel, p. 27-38, 1993.

ZAPISEK, W. F., CRONIN, G. M., LYN-COOK, B. D., POIRIER, L. A. The onset of oncogene hypomethylation in the livers of rats fed mettyl-deficient, amino acid-defined diets. Carcinogenesis, v. 13, p. 1869-1872, 1992.

ZECHMEISTER, L., DEUEL Jr., H. J., INHOFFEN, H. H., LEEMANN, J., GREENBERG, S. M., GANGULY, J. Stereochemical configuration and provitamin $A$ activity. $X$ A comparison of synthetic 15,15 monocis- $\beta$ carotene (central monocis- $\beta$-carotene) with all-trans- $\beta$-carotene in the rat and chick. Arch. Biochem. Biophys., v. 36, p. 80-88, 1952.

ZEISEl, S. H., DA COSTA, K. A., ALBRIGHT, C. D., SHIN, O. H. Choline and hepatocarcinogenesis in the rat Adv. Exp. Med. Biol, v. 375, p. 65-74, 1995.

ZENG, S., FURR, H. C., OLSON, J. A. Metabolism of carotenoid analogs in humans. Am. J. Clin. Nutr., v. 56, p. 433-439, 1992.

ZERBAN, H., RADIG, S., KOPP-SCHNEIDER, A, BANNASCH, P. Coll proliferation and coll death (apoptosis) in hepatic preneoplasia and neoplasia are closely related to phenotypic cellular diversity and instability. Carcinogenesis, v. 15, p. 2467-2473, 1994.

ZHANG, L. -X, COONEY, R. V., BERTRAM, J. S. Carotenoids up-regulate connexin 43 expression independent of their provitamin A or antioxidant properies. Cancer Res, v. 52, p. 5707-5712, 1992.

ZHANG, L. -X, ACEVEDO, P., GUO, H., BERTRAM, J. S. Upregulation of gap junctional communication and connexin 43 expression by carotenoids in human dermal fibroblasts but not in human keratinocytes. Mol. Carcinogenesis, v. 12, p. 50-58, 1995.

ZHANG, X -K., LIU, Y., LEE, M. -O., PFAHL, M. A. A specific defect in the retinoic acid response associated with human lung cancer cell lines. Cancer Res., v. 54, p. 5663-5669, 1994.

ZHANG, X. -K., LIU, Y., LEE, M. O. Retinoid receplors in human lung cancer and breast cancer. Mutat. Res., v. 350, p. 267-277, 1996.

ZHENG, Y., KRAMER, P. M., OLSON, G., LUBET, R. A, STEELE, V. E., KELOFF, G. J., PEREIRA, M. A. Prevention by retinoids of azoxymethane-induced tumors and aberrant cryps foci and their modulation of cell proliferation in the colon of rals. Carcinogenesis, v. 18, p. 2119-2125, 1997. 
ZHOU, H., MAN I, S. S., FINDLAY, D. M., MARTIN, T. J., HEATH, J. K., NG, K. W. Novel action of retinoic acid. J. Biol. Chem., v. 269, p. 22432-22439, 1994.

ZHU, W.Y., JONES, C. S., KISS, A, MATSUKUUMA, K., AMIN, S., DE L'UCA, L. M. Relinoic acid inhibition of cell cycle progression in MCF-7 human breast cancer cells. Exp. Cell Res, v. 234, p. 293-299, 1997.

ZEGLER, R G. Vegetables, fruits, and carotenoids and the risk of cancer. Am. J. Clin. Nutr., v. 53, p. 251S259S, 1991.

ZIEGLER, R. G., SUBAR, A. F., CRAFT, N. E., URSIN, G., PATTERSON, B. H., GRAUBARD, B, I. Does $\beta-$ carotene explain why reduced cancer risk is associated with vegetable and fruit intake? Cancer Res., v. 52, p. 2060S-2066S, 1992.

ZIEGLER, R. G., MAYNE, S. T., SWANSON, C. A. Nutrition and lung cancer. Cancer Causes \& Control, v. 7, p. 157-177, 1996 a.

ZIEGLER, R. G., COLAVITO, E. A, HARTGE, P., MCADAMS, M. J., SCHOENBERG, J. B., MASON, T. J., FRAUMENI JR, J. F. Importance of $\alpha$-carotene, $\beta$-carotene and other phytochemicals in the etiology of lung cancer. J. Natt. Cancer. Inst, v. 88, p. 612-615, $1996 \mathrm{~b}$.

ZINGG, J. -M., JONES, P. A Genebic and epigenetic aspects of DNA methylation on genome expression, evolution, mutation and carcinogenesis. Carcinogenesis, v. 18, p. 869-882, 1997. 


\section{SUMMARY}

\section{EFFECTS OF $\beta$-CAROTENE AND VITAMIN A ADMINISTRATION IN WISTAR RATS AT THE PROGRESSION PHASE OF THE "RESISTANT HEPATOCYTE" MODEL OF HEPATOCARCINOGENESIS}

In this study the effects of $\beta$-carotene and vitamin $A$ administration in pre-neoplastic and neoplastic lesions, on cell proliferation and on the methylation pattern of the proto-oncogenes $c$ Ha-ras and c-myc, as well as on the gene for HMGCOA redutase, were evaluated in Wistar rats at the progression phase of hepatocarcinogenesis. For this purpose the animals were submitted to the "resistant hepatocyte" model, i. e., to an injection of diethylnitrosamine (DEN) as an initiating carcinogen, followed by the administration of 2-acetaminofluorene and by a partial hepatectomy. Ten months after DEN injection, three different groups of experimental animals received by gavage, every other day and for eight consecutive weeks, $\beta$-carotene $(7 \mathrm{mg} / 100 \mathrm{~g}$ B.W.), vitamin A (1 mg/100 g B.W.) or corn oil (controls), respectively. Afterwards, the animals were killed. An hour before the sacrifice each one received 5-bromo-2'-deoxyuridine (BrDU; 10 $\mathrm{mg} / 100 \mathrm{~g} \mathrm{B.W}$.) in order to evaluate cell proliferation. The macroscopic observation of the liver showed that $\beta$-carotene and vitamina A reduced cancer incidence $(25 \%)$ in comparison to the control group (65\%), although only the retinoid reduced simultaneously both the incidence and total number of persistent nodules of hepatocytes. These results were confirmed by standard histopathological examination $(H \& E)$ of the liver sections. The morphometry of $\gamma G T$-positive preneoplastic lesions did not showed significant differences between the different experimental groups. However, $\beta$-carotene and vitarnin A administration reduced cell proliferation both in liver lesions (persistent nodules/cancers) and in surrounding tissues. Hipomethylation of c-myc and HMGCOA reductase genes were observed in persistente nodules of hepatocytes as well as in cancers, although it had not been influenced by the carotenoid or retinoid treatment $\beta$-Carotene administration increased the hepatic concentrations of the carotenoid, but not of retinol. Together, these results indicate the existence of an intrinsic activity of $\beta$-carotene, independent of its function as a provitamin A. Moreover, the data suggest that both the carotenoid and the retinoid have inhibitory actions on neoplastic lesions when administered during the progression phase of hepatocarcinogenesis. These activities could eventually involve an inhibition on cell proliferation, but not an action on the DNA methylation process. 